\author{
UNIVERSIDADE DE SÃO PAULO \\ FACULDADE DE FILOSOFIA, LETRAS E CIÊNCIAS HUMANAS \\ DEPARTAMENTO DE HISTÓRIA \\ PROGRAMA DE PÓS GRADUAÇÃO EM HISTÓRIA SOCIAL
}

BRUNO JEUKEN SOUZA

\title{
SALATHIEL CAMPOS: \\ ESPORTE E POLÍTICA (1926-1938)
}

Dissertação apresentada ao Programa de Pós Graduação em História do Departamento de História da Faculdade de Filosofia Letras e Ciências Humanas da Universidade de São Paulo, para obtenção do título de Mestre em História Social.

Orientador: Flavio de Campos

São Paulo

2017 
Autorizo a reprodução e divulgação total ou parcial deste trabalho, por qualquer meio convencional ou eletrônico, para fins de estudo e pesquisa, desde que citada a fonte.

Versão corrigida

Catalogação na Publicação

Serviço de Biblioteca e Documentação

Faculdade de Filosofia, Letras e Ciências Humanas da Universidade de São Paulo

JJ58s

$$
\text { Jeuken, Bruno }
$$

Salathiel de Campos: esporte e política (1926-

1938) / Bruno Jeuken ; orientador Flavio De Campos.

- São Paulo, 2017.

$163 \mathrm{f}$.

Dissertação (Mestrado) - Faculdade de Filosofia,

Letras e Ciências Humanas da Universidade de São

Paulo. Departamento de História. Área de concentração:

História Social.

1. História Social. 2. Salathiel de Campos. 3.

Movimento Negro. 4. São Paulo. 5. Esporte. I. De

Campos, Flavio, orient. II. Título. 


\section{Agradecimentos}

Três pessoas, e apenas elas, são as responsáveis por tudo que aconteceu e que está por vir em minha vida, minhas mães: Sandra Maria Jeuken, Aparecida Cristófalo e Deise Acácia. A elas devo tudo.

Agradeço a todos meus professores, em especial aqueles que foram os grandes responsáveis pela minha trajetória até aqui: Paulo Eduardo Stipp, José Antônio Vasconcelos, Júlio Pimentel Pinto, Francisco C. Palomanes Martinho e Flavio de Campos, a quem devo a grande oportunidade e privilégio que é participar do NAPLUDENS e poder realizar essa pesquisa. Agradeço também a todos os membros do LUDENS, especialmente a Willian Maranhão, amigo que tanto me ajudou e a quem jamais conseguirei retribuir tanto carinho e apoio.

Devo destacar comovidamente a enorme contribuição de Luiz Henrique de Toledo, Denaldo Alchorne de Souza e José Paulo Florenzano, os membros da banca de defesa que fizeram uma leitura generosa, com cuidado e atenção, e me presentearam com análises profundas, correções e novas ideias. Se há algum mérito neste trabalho, devo isso a eles e a meu orientador Flavio de Campos.

Uma vez que este trabalho só foi possível graças ao livro O Homem Negro no Esporte Bandeirante, cujo fio puxei até que descobrisse todo o resto da narrativa aqui apresentada, devo agradecer imensamente ao descobridor desta fonte: o generoso e brilhante Wilson Gambeta.

A alguns amigos devo leituras, dicas, sugestões, críticas, força e paciência: Vinicius Belizário, Suzane Jardim, Luiz Burlamaqui, Yuri Ribeiro, Victor Sá Ramalho Antônio, Breno Macedo, Rafael Hernandez Jabur, Igor Baccin Martins, Ian Chichiaro Gastim, Gisele Tronquini, e a minha companheira de todos os dias, Yara Commar Curia. 


\section{Resumo}

Esta pesquisa teve por objetivo estudar a relação entre a militância do movimento negro e a inclusão de jogadores negros no futebol de São Paulo, entre 1926 e 1938, por meio do trabalho de Salathiel de Campos. Jornalista negro e militante, sua carreira começou no início dos anos 20 e terminou, de forma trágica, em meados dos anos 40. Apesar disso, deixou uma obra da mais completa relevância para os estudos da História Social, no geral, e do Movimento Negro nos esportes, em particular. Na segunda metade dos anos 20, sua militância mais efetiva começou com a participação em uma campanha n'A Gazeta em defesa dos jogadores negros da época. No início dos anos 30, foi membro fundador da Frente Negra Brasileira e atuou de forma importante ao longo de boa parte dessa década. Mais tarde, com a ação repressiva do Estado Novo, os movimentos sociais e partidos políticos são abruptamente encerrados pelo governo varguista, e o ciclo de conquistas do movimento negro é interrompido por longos anos. Ao fim desse período ditatorial, também chega ao fim a carreira deste importante jornalista militante.

Palavras-chave: São Paulo, Imprensa, Movimento Negro, Salathiel de Campos, Esporte. Abstract

This research aims to study the relationship between the activism of the black movement and the inclusion of black players in the state of São Paulo's football between 1926 and 1938 through the work of Salathiel de Campos. A black journalist and social activist, his career began in the early twenties but tragically ended during the 1940's. Nonetheless, he left a social historical work of notable relevance that contributes not only to the history of football but also to the black movements' history itself. Salathiel was an active member of the black press who had a profound impact in the creation of the Brazilan Black Front after a successful and effective activism calling for the defense of black footballers of the time. This activism ended abruptly during Getúlio Vargas' dictatorship in mid-1930's when the Brazilian Black Front alongside other movements such as the Black Social Culture Club were deemed illegal. The early victories verified in 1926 were transformed into a melancholic defeat for the black movement struggles of the time.

Keywords: São Paulo, Press, Black movement, Salathiel de Campos, Sports.

\section{Lista de siglas}

APEA - Associação Paulista de Esportes Atléticos 
API - Associação Paulista de Imprensa

CAP - Clube Atlético Paulistano

CBD - Confederação Brasileira de Desportos

COI - Comitê Olímpico Brasileiro

FIFA - Fédération Internationale de Football Association

FNB - Frente Negra Brasileira

EJIG - Empresa Jornalística de Informações Gerais

LAF - Liga dos Amadores de Futebol

LPF - Liga Paulista de Football

PRP - Partido Republicano Paulista

SPAC - São Paulo Athletic Club

\section{Lista de imagens}

Imagem 1 - Salathiel entre seus colegas de trabalho, quarto homem na fileira da frente. Correio Paulistano, Caderno de Esportes, página 5, $3^{a}$ coluna. 13/01/1933.

Imagem 2 - Salathiel de Campos recebendo uma homenagem de seus companheiros do Clube Negro de Cultura Social em seu ambiente de trabalho. Correio Paulistano, Caderno de Esportes, página 18, $3^{a}$ coluna, 09/05/1937.

Imagem 3 - Mellinho e Augusto Americo, jogadores do Velo Clube de Rio Claro, estampados no Caderno de Esportes d'A Gazeta em 21/04/1926.

Imagem 4 - "Epaminondas Berlitz, o veterano centro-médio do seleccionado carioca"

Imagem 5 - Petronilho de Brito, convocado após a mobilização dos jornalistas n'A Gazeta, seria um dos destaques do Campeonato Interestadual.

Imagem 6 - Salathiel entre colegas de trabalho e dirigentes de clubes esportivos, segundo homem da direita para a esquerda na fileira de trás. A Gazeta, Caderno de Esportes, sem paginação, $3^{a}$ coluna. 26/03/1931.

Imagem 7 - Membros da Legião Negra. O primeiro à esquerda é Benedito de Toledo, do Clube Negro de Cultura Social, fundado por José Correia Leite.

Imagem 8 - Cabeçalho utilizado na publicação de todos os 17 capítulos do livro de Salathiel de Campos.

Imagem 09 - Norberto Rocha, dirigente do Clube Atlético Brasil. A Gazeta, Todos os Esportes, 19-01-1929. Pag 6, $4^{a}$ coluna.

Imagem 10 - Selecionado paulista de jogadores negros, organizado pelo C.A. Brasil em parceria com a LAF. A Gazeta, Todos os Esportes, 22-01-1929. Pag 8, $2^{a}$ coluna. 
Imagem 11 - Notas do Correio Paulistano a respeito do livro O Homem Negro no Esporte Bandeirante. 12/10/1934, pag 10, e 21/10/1934, pag 13.

Imagem 12 - Fotografia de Salathiel de Campos com os visitantes alemães, 27/03/1935.

Imagem 13 - Fotografia dos campeões olímpicos do Estados Unidos, Correio Paulistano, 21/08/1936, pag. 10. 


\section{Sumário}

INTRODUÇ̃̃O

O CAMINHO DA PESQUISA $\quad 11$

1. CAPÍTULO 1: UM CAIPIRA NEGRO NA CAPITAL 13

1.1. Do nASCIMENTO À MiLITÂNCIA: O QUe SABEMOS SOBRE SALATHIEL de CAMPOS? 20

1.2. UM CRONISTA RESPEITADO 27

1.3. MilitânCIa NO JORNAL A GAZETA (1926)

1.3.1. AS DISPUTAS ENTRE SELEÇÕES ESTADUAIS

1.3.2. A CHAVE PARA A VITÓRIA

1.3.3. A VITÓRIA

1.4. A MILITÂNCIA FORA DO PAPEL (1926-1937) 50

1.4.1. AÇÃO IMPERIAL PATRIANOVISTA

1.4.2. MOVIMENTO NEGRO

2. CAPÍTULO 2: O HOMEM NEGRO NO ESPORTE BANDEIRANTE (1931-1934)

$\begin{array}{ll}\text { 2.1. O LIVRO } & 71\end{array}$

2.1.1. A HISTÓRIA DO BANDEIRANTE

2.1.2. ENTRE O ACADÊMICO, O MILITANTE E O ÉPICO 79

2.2. "BULIRA EM CASA DE MARIBONDOS"

2.2.1. O FUTEBOL E A RAÇA

2.2.2. A VÁRZEA E O FUTEBOL AMADOR 89

2.3. O “ROSÁRIO DE GLÓRIAS”

$\begin{array}{ll}\text { 2.3.1 BRANCOS CONTRA NEGROS } & 108\end{array}$

2.3.2. NOVAS PERSPECTIVAS 120

3. CAPÍTULO 3: SALATHIEL EM ASCENSÃO, MOVIMENTOS SOB OPRESSÃO (1935-1938) 123

3.1. OLIMPÍADAS DE $1936 \quad 125$

3.1.1. A UTOPIA ESPORTIVA DE SALATHIEL

3.1.2. UM RECADO AO BRASIL: OS RACISTAS DOS EUA E OS NEGROS CAMPEÕES

3.2. AO CORRER DA PENNA $\quad \mathbf{1 3 5}$

3.2.1. CAMPos no Correio PaUlistano, MazZONI n'A Gazeta 137

3.2.2. A COPA DE $1938 \quad 142$

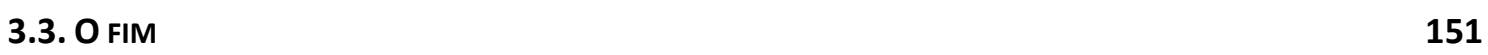

4. CONCLUSÃO

$\begin{array}{lr}\text { 4.1.1. PESQUISAS POSTERIORES } & 160\end{array}$

5. BIBLIOGRAFIA 162

$\begin{array}{ll}\text { 5.1. FONTES } & 165\end{array}$

5.1.1. COLETÂNEAS DE FONTES 165

5.1.2. JORNAIS 165

5.2. BIBLIOGRAFIA GERAL 165

5.3. LIVROS E ARTIGOS ESPECIALIZADOS

\section{Introdução}




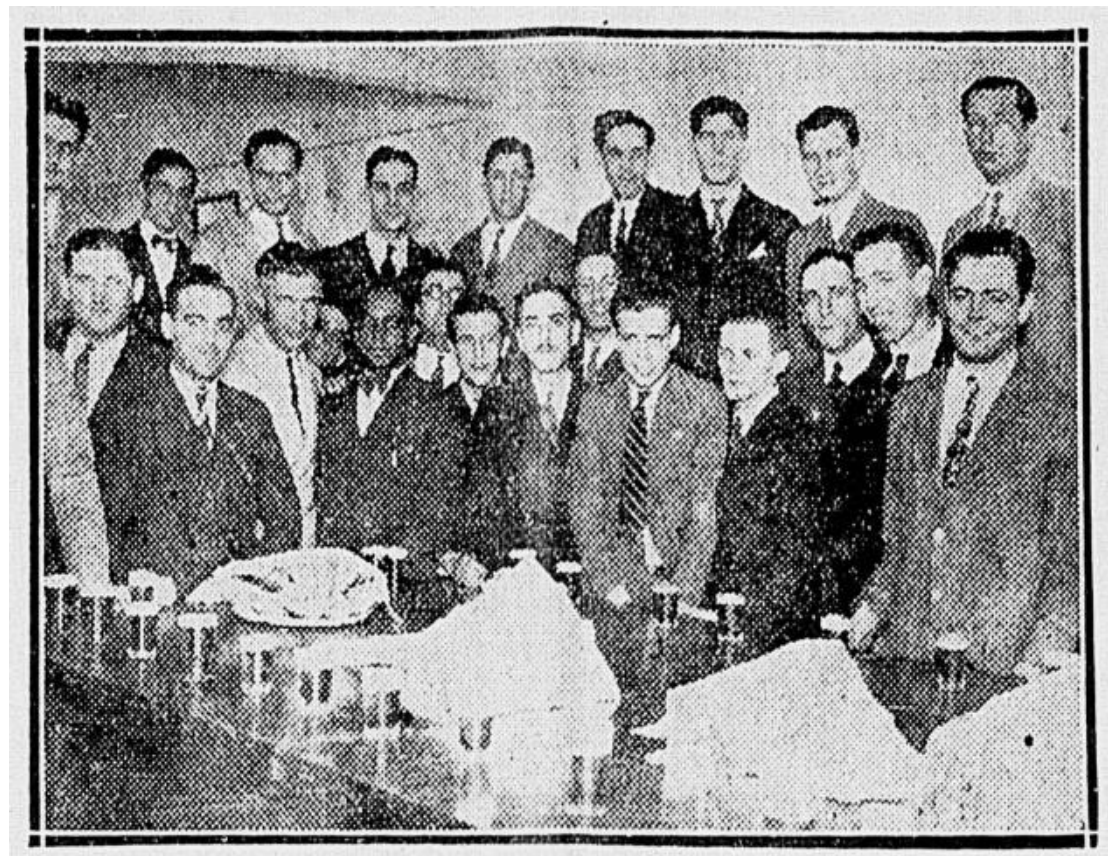

REDATORES ESPORTIVOS DOS JORNAIS DESTA CAPITAL QUE COMPARECERAM A INAUGURACAO DA E. J. I. G.

Imagem 1 - Salathiel entre seus colegas de trabalho, quarto homem na fileira da frente. Correio Paulistano, Caderno de Esportes, página 5, 3를 coluna. 13/01/1933. ${ }^{1}$

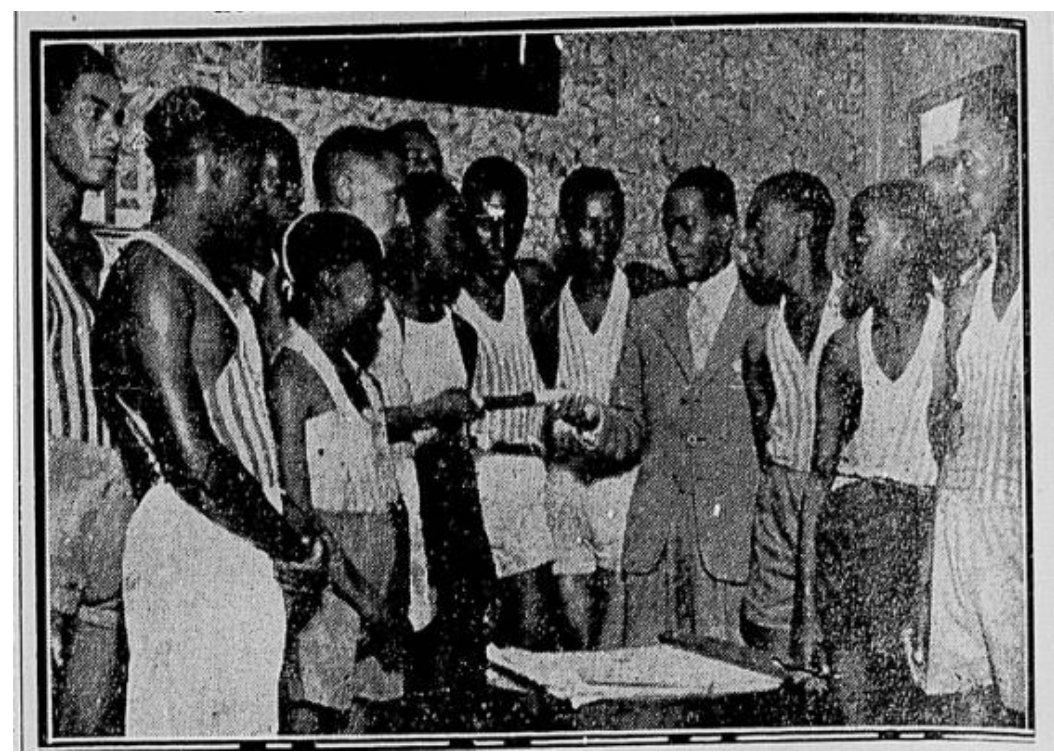

Imagem 2 - Salathiel de Campos recebendo uma homenagem de seus companheiros do Clube

Negro de Cultura Social em seu ambiente de trabalho. Correio Paulistano, Caderno de Esportes, página 18, 3를 coluna, 09/05/1937. ${ }^{2}$

"Mas um dia, quando o tempo (só o tempo) processar a natural transformação dos cerebros obliterados dos homens de hoje, se dará ao negro o seu logar de destaque no concerto geral do paiz. E esse dia não

\footnotetext{
${ }^{1}$ Disponível em <http://bndigital.bn.br/hemeroteca-digital/> Acesso em 05/06/2015.

${ }^{2}$ Disponível em <http://bndigital.bn.br/hemeroteca-digital/> Acesso em 02/07/2015.
} 
tardará. Será a 'Justiça de Deus na voz da História'. Deixemos, pois, aos estudiosos da sociologia essa tarefa de acompanhar 'pari-passu' essa transformação e relatar aos posteros as particularidades interessantes da evolução." Salathiel de Campos ${ }^{3}$

A pesquisa apresentada nessa dissertação tenta realizar uma história política entre os últimos anos da Primeira República e os primeiros oito anos da Era Vargas, de Washington Luís ao Estado Novo. Na história política desse período, estamos especialmente preocupados com a participação do movimento negro no campo esportivo, no geral, e com Salathiel de Campos, em particular. Esse foi um agente que transitou por diversos campos de sua época, militante e membro fundador de jornais da chamada Imprensa Negra, da Ação Imperial Patrianovista Brasileira (3 de março de 1928), da Frente Negra Brasileira (16 de setembro de 1931), do Clube Negro de Cultura Social (1 de julho de 1932), escritor de livros como Nossos Campeões (1931) e O Homem Negro no Esporte Bandeirante (escrito em 1932, publicado em 1934), e que teve uma história tão importante quanto trágica. Por várias razões, algumas delas ainda por serem estudadas, Salathiel de Campos ficou esquecido pela historiografia brasileira. Uma delas: não ter sido citado por nenhum de seus contemporâneos, entre os quais estão grandes expoentes da literatura a respeito do futebol brasileiro. Thomaz Mazzoni, que chegou a ser seu chefe, e Mário Filho, para citar apenas dois exemplos.

A historiografia do futebol é, hoje, muito rica e diversa. Conhecemos o futebol da Primeira República com Malaia Santos na sua tese Revolução Vascaína ${ }^{4}$, também com Wilson Gambeta, mais voltado ao começo do mesmo período, em A Bola Rolou ${ }^{5}$. A questão racial no futebol foi analisada, por exemplo, por Antônio Jorge Soares em Futebol, raça e nacionalidade no Brasil ${ }^{6}$, e o importante tema da nacionalidade e da identidade nacional atreladas ao futebol foi estudado, para citar apenas dois exemplos, por Denaldo Alchorne de Souza em $O$ Brasil entra em campo $^{7}$ e por Simoni Guedes, em

\footnotetext{
${ }^{3}$ Correio Paulistano, Caderno de Esportes, O Homem Negro no Esporte Bandeirante, 03-11-1934, pg.7. disponível em <http://hemerotecadigital.bn.br/acervo-digital/> acesso em 12/11/2014.

${ }^{4}$ SANTOS, João Manuel Casquinha Malaia. Revolução Vascaína: a profissionalização do futebol e inserção sócio-econômica de negros e portugueses na cidade do Rio de Janeiro (1915-1934). 2010. Tese (Doutorado em História Econômica) - Faculdade de Filosofia, Letras e Ciências Humanas, Universidade de São Paulo, São Paulo, 2010.

${ }^{5}$ GAMBETA, Wilson. A bola rolou: o velódromo paulista e os espetáculos de futebol. São Paulo: SESIEditora, 2015.

${ }^{6}$ SOARES, Antônio Jorge. Futebol, raça e nacionalidade no Brasil: releitura da história oficial. Rio de Janeiro, Universidade Gama Filho, Programa de Pós-Graduação em Educação Física, tese de doutorado, 1998.

${ }^{7}$ DE SOUZA, Denaldo Alchorne. O Brasil entra em campo, Construções e reconstruções da identidade nacional (1930-1947). São Paulo: Annablume, 2008. 220p.
} 
O Brasil no Campo de Futebol ${ }^{8}$ e Futebol brasileiro: instituição zero ${ }^{9}$. Uma importante produção acadêmica sobre os temas que permeiam minha dissertação.

O que buscamos foi juntar todos estes em uma dissertação que, acima de tudo, apresentasse novamente aos campos esportivo e acadêmico essa personagem histórica, que também trata, ela mesma, desses que são os alguns dos principais temas da História do Esporte no Brasil: a identidade, a nação e a raça.

A isca para o historiador foi o livro O Homem Negro no Esporte Bandeirante, escrito em 1932 e publicado em 1934. Esta fonte foi descoberta pelo historiador Wilson Gambeta, que me indicou o texto para que eu pesquisasse a ideia de futebol arte - que de certa forma se faz presente ali. Esse era o objeto da minha pesquisa naquela altura. $\mathrm{O}$ texto, em um primeiro momento, parece uma ideia fora do lugar ${ }^{10}$, mas ao conhecer a história de Salathiel de Campos entendemos melhor sua existência. Quanto mais informações sobre este jornalista era encontrada, mais ele parecia importante e interessante. Puxando este fio, consegui traçar, bem ou mal, a história de vida de Salathiel desde o seu nascimento até sua morte trágica. Em pouco tempo, ele tornou-se o protagonista da pesquisa. Então, o esforço foi de buscar respostas às perguntas que giravam ao redor de sua história, entender melhor de onde vinham suas opiniões, onde e como ele as formou, com quem concordava e com quem discordava, mapeando seu lugar em processos mais amplos.

Não se trata de interpretar o texto por meio do contexto, mas explicar, em primeiro lugar, a existência do texto e seu lugar em sua própria época. Como dito por Hilário Franco Júnior, com a "remoção da oligarquia paulista do centro do poder" em 1930, a modernização "tornou-se a palavra de ordem" e "no futebol também se viviam tempos de transição" "11. É nessa transição que se insere a atuação e influência do movimento negro paulistano. Salathiel de Campos faz parte dessa história atuando em dois campos: o político e o esportivo. Como demonstrado Pierre Bourdieu em $O$ poder simbólico ${ }^{12}$, campo é um espaço simbólico no qual os agentes envolvidos determinam, validam e/ou legitimam certas representações, e também quais valores e rituais as constituem. $\mathrm{O}$ sociólogo diz ainda que os campos são autônomos, com regras próprias, mas interagem

\footnotetext{
${ }^{8}$ GUEDES, Simoni Lahud. O Brasil no campo de futebol: estudos antropológicos sobre os significados do futebol brasileiro. EDUFF, 1998.

${ }^{9}$ GUEDES, Simoni. O Futebol Brasileiro: instituição zero. Rio de Janeiro: Universidade Federal do Rio de Janeiro, Dissertação de Mestrado, 1977.

${ }^{10}$ SCHWARZ, Roberto. Ideias fora do lugar. São Paulo: Penguin, 2014.

${ }^{11}$ FRANCO JR., Hilário. Dança dos Deuses. São Paulo: Cia. das Letras. 2007. Pg. 77.

12 BOURDIEU, Pierre. O poder simbólico. Rio de Janeiro: Bertrand Brasil, 2012, p. 9.
} 
de várias formas, e uma delas é a circulação de agentes. Essa conexão entre os espaços sociais é chamada de superfície social. Observando esta superfície social, conseguimos conceber melhor a complexidade desta personagem ${ }^{13}$.

A história de Salathiel de Campos é a história da luta pela integração do negro, dos avanços como resultado de luta e não de concessão. História de quem conviveu e flertou com o mito da democracia racial. De quem participou de alguns dos principais movimentos políticos de sua época. É a história de um autor importante para quem quer conhecer a história do esporte paulista. Também a história das primeiras ideias sobre a prática que, mais tarde, seria conhecida como futebol arte.

Falando mais especificamente, o livro O Homem Negro no Esporte Bandeirante, trazido novamente à luz, irá completar uma ilustre sequência de obras a respeito da questão racial no esporte. Quando se busca essa historiografia, em geral, o marco de início é Gilberto Freyre, Mario Filho ou Anatol Rosenfeld ${ }^{14}$. Marcel Tonini, que estudou a história oral de vida de negros no futebol brasileiro ${ }^{15}$, faz uma retrospectiva desses estudos que elenca, além dos já citados, os trabalhos de Joel Rufino do Santos, em História Política do Futebol Brasileiro ${ }^{16}$, Marcos Alves de Souza, com sua dissertação Gênero e Raça ${ }^{17}$, e de César Gordon Júnior, que escreve dois artigos sobre a História Social dos negros no futebol brasileiro, em 1995 e $1996^{18}$. Para não citar também Ronaldo Helal, Jorge Murad, José Jairo Vieira e José Miguel Wisnik. Esses autores todos fizeram parte deste trabalho, naturalmente, e acredito que seus próprios trabalhos teriam com Salathiel de Campos uma valiosa contribuição.

Tivemos o cuidado, moldado pelo método, de não transformar essa personagem histórica em um mito ou um herói. Nossa preocupação é a história com suas

\footnotetext{
13 BOURDIEU, Pierre. "A ilusão biográfica”. In: Razões práticas: sobre a teoria da ação. Campinas: Papirus, 1996.

${ }^{14}$ ROSENFELD, Anatol. Negro, macumba e futebol. São Paulo: Perspectiva/Edusp; Campinas: Ed. da Unicamp, 1993.

${ }^{15}$ TONINI, Marcel Diego. Além dos gramados: história oral de vida de negros no futebol brasileiro. Tese (Doutorado em História Social) Faculdade de Filosofia, Letras e Ciências Humanas, Universidade de São Paulo. São Paulo, 2010.

${ }^{16}$ SANTOS, Joel Rufino dos (Org.). História política do futebol brasileiro. São Paulo: Brasiliense, 1981.

17 SOUZA, Marcos Alves. Gênero e raça: a nação construída pelo futebol brasileiro. Cadernos Pagu, Campinas, n.6/7, p. 109-152, 1996. Raça e gênero.

${ }^{18}$ GORDON JÚNIOR, Cesar. Eu já fui preto e sei o que é isso: história social dos negros no futebol brasileiro: segundo tempo. Pesquisa de Campo, Rio de Janeiro, Eduerj, n. 3/4, p. 65-78, 1996. Futebol: síntese da vida brasileira. . História social dos negros no futebol brasileiro: primeiro tempo: -essa maravilhosa obra de arte fruto da misturall. Pesquisa de Campo, Rio de Janeiro, Eduerj, n. 2, p. 71-90, 1995. Futebol e cultura brasileira.
} 
complexidades: com avanços e retrocessos, conquistas e derrotas, certezas e ambiguidades, as vezes condizente, outras vezes contraditória. Ainda assim, precisamos reconhecer que Salathiel de Campos foi alguém que lutou aquela que, arrisco dizer, foi a principal batalha de sua época: a luta contra o racismo.

\section{O caminho da pesquisa}

Escrever história é lidar com várias temporalidades, vários processos imbricados, complexos. O historiador, no tempo presente, se debruça sobre os agentes de um tempo passado e, no meu caso, um desses agentes se debruça, por sua vez, sobre o seu próprio passado. É de se imaginar, mas digo: apesar de se tratar dos mesmos anos cronológicos, o passado de Salathiel de Campos não é o mesmo passado do historiador. Sua leitura do início dos anos XX não é a mesma que tenho agora. Por isso, lidando com três temporalidades - a minha, a do meu objeto e a estudada pelo meu objeto - tivemos nesta pesquisa uma variedade grande de interpretações sobre o passado.

Para alcançar essas temporalidades, dois caminhos foram seguidos pela pesquisa: partindo do objeto de estudo e da fonte principal - Salathiel Campos e O Homem Negro no Esporte Bandeirante - realizando uma retrospectiva em busca de causas; e depois, partindo novamente deste livro, realizando um estudo dos desdobramentos. Nesse processo, o livro em si não se mostrou o centro de um processo de mudança, algo que tivesse grandes desdobramentos para a história do campo esportivo e político da época. Se mostrou, isso sim, um marco na biografia de Salathiel, que após essa publicação chegou a chefe de redação no Correio Paulistano e passou a ter uma coluna diária.

Por esse caminho, a pesquisa centrado no texto se mostrou produtiva. Uma vez que estudamos um agente do campo esportivo cujo ofício se dá pela escrita e, diga-se, num tempo no qual as palavras impressas no jornal são o centro da circulação de informações, ideias, conhecimento e da formação de opinião, seus textos são, de fato, o eixo principal de sua história, seja qual for o efeito desde ou daquele texto.

Como limites temporais, identifiquei dois momentos relativos à história dos jogadores negro no campo esportivo. Em 1926, Salathiel de Campos trabalhava n'A Gazeta e ali aproveitou seu espaço na imprensa para fazer parte de uma campanha pela convocação de jogadores negros à Seleção Paulista de futebol. O jornalista Leopoldo Santana, que já trabalhava no jornal desde 1918, participou ativamente da campanha e é tido por Salathiel de Campos como um dos principais nomes deste movimento - o grande 
nome do caderno de esportes d'A Gazeta, Thomaz Mazzoni, foi contratado apenas dois anos depois, em $1928^{19}$. Uma vez que pretendo evidenciar a integração do negro como resultado de luta e reivindicação, essa mobilização política pela imprensa determinou o início do meu trabalho.

O final do recorte é a soma de dois momentos: em 1937, Vargas põe fim aos partidos políticos por decreto. Entre eles, a Frente Negra Brasileira. No ano seguinte, 1938, uma seleção brasileira repleta de jogadores negros - entre eles dois grandes expoentes: Domingos da Guia e Leônidas - atrai as atenções do mundo ao conquistar a melhor campanha do Brasil em Copas do Mundo até aquela data. Após o silenciamento de um movimento, que foi ele próprio um dos responsáveis pela entrada de jogadores negros no futebol oficial, as conquistas tiveram sobrevida apenas parcial. A militância é encerrada à força, e o que resta é a serventia de certos atletas negros como funcionários do espetáculo.

Não se trata de encarar o futebol como apolítico ou alienante. Trata-se, pelo contrário, de colocar em evidência as disputas políticas no campo esportivo, as conquistas alcançadas pelos agentes que militavam pelo movimento negro, assim como as limitações impostas a eles em determinado momento histórico. A ideia não é dizer que a política só é possível fora do futebol, mas sim mostrar como o futebol é também político. Negar a entrada de negros no futebol oficial é, além de racista, um ato político. Aceitar a entrada de negros que tivessem qualidade comprovada, sem que isso significasse uma assimilação, é um ato político. A referência a jogadores negros, recém incluídos no espetáculo futebolístico, como suposta confirmação do mito da democracia racial é um ato político.

Em resumo, buscamos responder três perguntas:

Quem é Salathiel de Campos?

Como a mobilização da população negra atuou no campo esportivo da época e qual a participação de Salathiel de Campos nesse processo?

Como se tornou possível a existência do livro O Homem Negro no Esporte Bandeirante, na época em que foi publicado e com o conteúdo que foi apresentado?

Quais as causas do esquecimento de Salathiel de Campos pelos seus contemporâneos e, consequentemente, pelos que vieram depois?

\footnotetext{
${ }^{19}$ TOLEDO, Luiz H. de. A cidade e o jornal: a Gazeta Esportiva e os sentidos da modernidade na São Paulo da primeira metade do século XX. In: BUARQUE DE HOLLANDA, Bernardo; MELO, Victor A (orgs.). O esporte na imprensa e a imprensa esportiva no Brasil. Rio de Janeiro: 7Letras, 2012. pag. 62.
} 
Será uma tarefa complicada, mas é o que tentaremos explicar dentro das limitações intelectuais e técnicas deste historiador. Ainda assim, dada a importância deste personagem para a história do esporte e do movimento negro brasileiros, a expectativa é que este trabalho motive outros, estes mais bem sucedidos.

\section{Capítulo 1: um caipira negro na capital}

"Ha, na vida da humanidade, um único elemento capaz de congregar todos os homens num amplexo de confraternização e cordialidade: o esporte.

Desde que o mundo é mundo, as civilizações passaram entôando os seus hymnos de...paz e amor...Mas os cyclos passaram e os homens continuam divididos em raças e castas.

Embalde as chamadas elites realizam os banquetes de cordealidade porque todos os sentimentos maus continuam a dominar o coração do homem."

Salathiel de Campos, $1936^{20}$.

No dia 16 de Janeiro de 1945, uma terça-feira, o jornalista Salathiel Gumercindo de Campos, então com 44 anos de idade, se aprontou para mais um dia de trabalho. A roupa, uma forma de distinção, ainda mais por ter sido um profissional negro em ambiente majoritariamente branco, era sempre muito bem escolhida ${ }^{21}$. Conhecido como persistente $^{22}$, e frequentemente homenageado ${ }^{23}$, o respeitado cronista, chefe de redação e conselheiro da Associação Paulista de Imprensa, saíra para trabalhar sem saber que naquele dia sua vida mudaria definitivamente.

Antes disso, é provável que tenha se despedido de sua esposa, Celisa Vieira de Campos, com quem era casado há vinte anos. Sua companheira era dona de casa e havia sido professora de música ${ }^{24}$ nos projetos educacionais da Frente Negra Brasileira cerca

\footnotetext{
${ }^{20}$ DE CAMPOS, Salathiel. Correio Paulistano, 19/08/1936 - pag 10. Disponível em $<$ http://bndigital.bn.gov.br/hemeroteca-digital/>

${ }^{21}$ FERREIRA, Maria Cláudia. Espaços de sociabilidade e ações anti-racismo no cotidiano das elites negras na cidade de São Paulo: busca por projeção individual e legitimidade de grupo (1900-1940). Revista Mosaico, no 3, ano II, 2010. Pag.4

22 II Pasquino Coloniale, 20/03/1937, Caderno de Esportes. Disponível em $<$ http://bndigital.bn.gov.br/hemeroteca-digital/>

${ }^{23}$ Correio Paulistano, 10/10/1941, pag. 7. Disponível em <http://bndigital.bn.gov.br/hemerotecadigital/>

${ }^{24}$ BARBOSA, Márcio. Frente Negra Brasileira: depoimentos. São Paulo: Quilombhoje, 1998.
} 
de dez anos antes. A essa altura, e talvez eles nem soubessem disso, ela estava grávida de seu terceiro filho.

O primeiro, que recebeu o nome do pai, nascera logo após o casamento e, tragicamente, morreu aos dois anos de idade (28 de novembro de 1927). Sobre o segundo, foram encontradas poucas informações. Sabemos apenas que se chamava Nestor, fazia aniversário no dia 4 de dezembro, e que em 1935 já havia nascido ${ }^{25}$. O terceiro, Pedro Paulo de Campos, que então ainda era gestado na barriga da mãe, nasceria no dia 20 de setembro daquele ano $^{26}$.

Não sabemos se já moravam em uma casa na rua Marselhesa, número 271, na Vila Mariana, o que é provável, ou se ainda moravam à rua Siqueira Campos, número 42, na Liberdade. Fosse o segundo caso, Salathiel de Campos deve ter ido a pé ao trabalho. Ele era chefe da redação de esportes no Correio Paulistano, que ficava à rua Libero Badaró, esquina com o Largo de São Bento.

A depender do ano, trabalhava em um ou outro jornal, sempre em mais de um ao mesmo tempo. Foram eles: A Gazeta, O Combate, Correio da Tarde, São Paulo Jornal, Última Hora, Revista Olympia, Correio Paulistano e Diário Oficial. Em geral, fazia meio período em cada veículo, como é possível constatar quando os jornais informam seu expediente aos leitores interessados em encontrá-lo, uma vez que, sempre envolvido na organização de eventos esportivos, ficava responsável por vender ingressos, receber doações, distribuir convites e afins ${ }^{27}$.

Facilmente, um leitor (ou mesmo o historiador muito tempo depois) pode descobrir sua rotina. Se alguém quisesse comprar um ingresso de um jantar de arrecadação de fundos para o ciclismo, ou participar de uma competição de

\footnotetext{
${ }^{25}$ Correio Paulistano, 04/12/1935, pag. 6. Disponível em <http://bndigital.bn.gov.br/hemerotecadigital/>

${ }^{26}$ Diário Oficial, 20/12/1974, pag 62, 2a coluna. Disponível em

<https://www.imprensaoficial.com.br/DO/BuscaDO2001Documento 11 4.aspx?link=/1974/judiciario/d ezembro/20/p1/pag 0062 7AIJDI5MFM6M8e9171CEP0K2HIV.pdf\&pagina=62\&data=20/12/1974\&cade rno=Judici\%C3\%A1rio\&paginaordenacao=100062>. Pedro Paulo de Campos, como mostra essa página do diário oficial, casou-se com Emelia Cosmo de Oliveira em 20/12/1974, próximo ao aniversário de morte do pai. Ele, porteiro, e ela, empregada doméstica, ambos residentes no bairro da Saúde.

${ }^{27}$ A Manhã, 13/11/1929, pag 5. Disponível em <http://bndigital.bn.gov.br/hemeroteca-digital/>. e Correio Paulistano, 27/05/1930, pag 11. Disponível em <http://bndigital.bn.gov.br/hemerotecadigital/>.
} 
pedestrianismo, era só esperá-lo na saída do jornal, ou mesmo verificar em qual prédio ele estaria neste ou naquele horário para encontrá-lo ali mesmo na redação.

Às 14 horas daquele dia, Salathiel foi abordado por um desses leitores, mas por outras razões. Antonio Almeida Soares, um pugilista português estava indignado com uma coluna que o havia criticado, e resolveu tirar satisfações com o jornalista, como era costume nas redações daquele tempo. Mas o brutamontes português foi além. Desferiu dois socos profissionais direto na cabeça de Salathiel de Campos. Podemos saber mais detalhes sobre o ocorrido graças à homenagem de um amigo, escrita anos depois no Diário Oficial:

\begin{abstract}
"Sobre sua bondade e seu caráter, duas particularidades num mesmo caso, por sinal doloroso, bem dizem do que foi Salathiel de Campos. Houve uma luta de box no Pacaembu em certa noite. Um companheiro, então responsável pela secção de pugilismo, escreveu um comentário e criticou o modo de agir de um dos participantes da luta, em Ultima hora. Salathiel, que nada vira, não escrevera, vinha no dia seguinte à redação, ali pelas 14 horas. Estava sendo aguardado pelo pugilista criticado, que não continha seu ódio, terminando por agredi-lo de modo estúpido, incrível. Segurou nosso companheiro pela capa e deu-lhe dois violentos murros de um pêso pesado. Minutos após, chegávamos ao escritório e víamos Salathiel quase desacordado e, então o levamos ao Pôsto de Assistência Pública para ser socorrido. Resistiu o companheiro e voltou ao trabalho" 28
\end{abstract}

Houve uma mobilização imediata, e os veículos de imprensa se manifestaram em defesa do companheiro de profissão. O jornal $O$ Estado de São Paulo publica no dia seguinte ao ataque:

\title{
Um cronista paulistano vitima de brutal agressão
}

São listados telegramas e mensagens:

Dr. Gabriel Monteiro da Silva, presidente do Conselho Regional de Esportes do Estado de S. Paulo: "venho trazer ao prezado amigo e ilustrado jornalista minha expressão formal contra a insólita agressão que veio ferir toda uma classe"

Da secretaria da Associação dos Cronistas Esportivos do Estado de São Paulo: "A diretoria da A.C.E.E.S.P. deseja publicamente lançar o seu protesto contra a atitude do pugilista português (...) em reunião extraordinária [a diretoria] deliberou solicitar a todos os seus associados para que suspendam todo e qualquer noticiário

${ }^{28}$ SÃO PAULO, Diário Oficial, Requerimento no 1074.52, 15 de setembro de 1952. pag.52-53. 
de lutas em que participe o referido lutador, bem como endereçou á diretoria da Federação Paulista de Pugilismo o seguinte telegrama: (...)vimos á presença de V.S. protestar energicamente exigindo medidas severas para que, no futuro, possa essa prestigiosa entidade contar todo o apoio que sempre mereceu da Associação dos Cronistas Esportivos do Estado de S. Paulo. ${ }^{29}$

Um dia depois dessa publicação, O Correio Esportivo, caderno do Correio da Manhã, também se manifesta:

\section{Porque a critica desagrada}

Em qualquer ramo da atividade humana a critica é necessária (...)

Em São Paulo, ante-ontem, um jornalista dos mais brilhantes, o nosso colega Salathiel Campos, foi vitima de brutal agressão, em plena redação do 'Correio Paulistano' por parte do jogador de box português Antonio Soares. Aquele cronista, que é chefe da secção esportiva do aludido periódico, estampara uma cronica de certo match em que o pugilista português tomara parte e, pela sua conduta, em vez de boas, mereceu más referências. Foi o bastante para o brutamontes invadir a redação e exigir uma retratação $(\ldots)^{30}$

A Associação Brasileira de Imprensa emitiu também uma nota no jornal $O$ Globo, do Rio de Janeiro, se solidarizando com Salathiel de Campos ${ }^{31}$. O Jornal dos Sports, comandado à época por Mário Filho, informou que a Confederação Brasileira de Pugilismo (CBP) mandara uma carta à Associação dos Cronistas Esportivos (da qual Salathiel de Campos era membro fundador, aliás) lamentando o acontecimento e prestando solidariedade. Disse também o diretor da CBP que enviou uma carta à Federação Paulista solicitando providências contra o agressor ${ }^{32}$.

A Folha da Manhã, O Globo, o Jornal dos Sports, o Correio Paulistano, A Manhã, entre outros veículos, cobriram o desenrolar do caso. No dia 21 de fevereiro, mais de um mês depois, a $7^{\mathrm{a}}$ vara da cidade de São Paulo abriu inquérito contra Antonio Soares, como noticiado pela Folha da Manha $\tilde{a}^{33}$ e pelo $O$ Globo $^{34}$. Pelo que foi visto nessas fontes,

\footnotetext{
${ }^{29}$ O Estado de São Paulo, 17/01/1945, pag 8

${ }^{30}$ Correio da Manhã, Correio esportivo, página 12, 18/01/1945. Disponível em $<$ http://bndigital.bn.gov.br/hemeroteca-digital/>

${ }^{31}$ O Globo, 19/01/1945, pag 8 Disponível em <http://acervo.oglobo.globo.com/>

32 Jornal dos Sports, 20/01/1945, pag 6 Disponível em <http://bndigital.bn.gov.br/hemeroteca-digital/>

${ }^{33}$ Folha da Manhã, 21/02/1945. Disponível em <http://bndigital.bn.gov.br/hemeroteca-digital/>

${ }^{34}$ O Globo, 22/02/1945. Disponível em <http://acervo.oglobo.globo.com/>
} 
não parece ter havido grandes consequências ao agressor a não ser o seu afastamento das atividades no boxe.

Foram anos difíceis para Salathiel de Campos aqueles que se seguiram. Aos poucos, seu nome sumiu das páginas de jornal. Há uma aparente decadência profissional devido ao afastamento causado pelas sequelas. Passou a trabalhar menos, o que também significava ganhar menos dinheiro - ou nenhum. Talvez como uma forma de ajudá-lo, dada a comoção em torno do caso, quatro meses após o ataque foi efetivado como redator do Diário Oficial ${ }^{35}$, cargo que ocupava como interino ou comissionado desde algum momento anterior a $1942^{36}$. Possivelmente, nos anos após a agressão, essa foi sua única fonte de renda.

A gestação de Celisa, sua esposa, deve ter sido no mínimo complicada, uma vez que tanto ela quanto o marido, por razões diferentes, estavam precisando de acompanhamento médico. Em 20 de setembro, nasce Pedro Paulo de Campos em um hospital no bairro da Saúde, em São Paulo. Mesmo com um filho recém-nascido e carregando as sequelas da agressão que sofreu, Salathiel de Campos continuou a colaborar, como fizera ao longo das décadas anteriores, com a militância do movimento negro.

Ele foi um dos diretores da Convenção Política do Negro Brasileiro, em novembro de $1945^{37}$. Significativa e simbolicamente, um mês depois da deposição de Getúlio Vargas, cujo período ditatorial do Estado Novo havia exterminado todo o suporte político que o movimento negro dava a Salathiel de Campos em suas lutas diárias na imprensa paulista. No início do ano seguinte, constava como um dos colaboradores da revista Senzala, "a revista mensal do negro" 38 . Mas, apesar de continuar ativo, a sua condição financeira parece ter ido mesmo de mal a pior.

Ainda assim, conta aquele mesmo amigo que, como um bom católico:

\footnotetext{
${ }^{35}$ Diário Oficial, 16/05/1945 - pag 3. Disponível em <https://www.imprensaoficial.com.br/\#10/10/2017> ${ }^{36}$ O decreto-lei utilizado para efetivá-lo dizia que: Poderá ser efetivado no cargo de que for ocupante, a juízo do Chefe do Governo e mediante proposta do Departamento do Serviço Público, o funcionário interino ou comissionado que houver ingressado no serviço público antes de 25 de janeiro de 1942. ${ }^{37}$ Folha da Manhã, 12/11/1945, pag 20. Disponível em <http://bndigital.bn.gov.br/hemeroteca-digital/> ${ }^{38}$ Revista A Senzala, Jan/1946. Disponível em <http://bndigital.bn.gov.br/hemeroteca-digital/>
} 
"tempos depois, atendendo intermediários, Salathiel perdoou seu agressor, com o qual saiu em clichês publicados no jornal um abraço sincero e sorrindo.

Ocorrera que o agressor de Salathiel, tendo sido expulso da Federação de Pugilismo, foi procurar sua vítima para implorarlhe o perdão, única condição que lhe permitiria o retorno aos ringues brasileiros. Nessa altura, o jornalista já se encontrava recolhido ao leito, acometido do primeiro derrame cerebral de uma série que se sucederia. O pugilista evocou razões que desprezara no ato da agressão. Ponderou que não tinha outra profissão, que o sustento de sua espôsa e filhos dependeria de sua reabilitação no box. Salathiel que não sabia odiar, perdoou seu assassino. Em seu coração plasmado nos sadios princípios das leis Divinas, não havia lugar para o desprezo e nem ressentimentos! "39

Em uma publicação do Diário Oficial de 1949, foram negados os pedidos de aposentadoria de Salathiel de Campos pelas funções de redator do Diário Oficial (cargo no qual ele havia sido efetivado no ano da agressão) e de auxiliar do $4^{\circ}$ Registro de Hipotecas (cargo que provavelmente ocupou antes mesmo de ingressar na carreira de jornalista $)^{40}$. Dada essa sequência de fatos, podemos supor que o quadro de saúde de Salathiel de Campos havia piorado, assim como sua situação financeira, o que levou aos pedidos de aposentadoria com o objetivo de cuidar da saúde e ao mesmo tempo manter uma fonte de renda, ainda que incipiente.

Nesse mesmo ano, um momento feliz em meio à decadência física e financeira:

\section{Bodas de Prata}

Transcorre no próximo dia 24 a passagem do $25^{\circ}$ aniversário de casamento do sr. Salathiel de Campos e sua esposa, d. Celisa Vieira de Campos.

Festejando a passagem da efeméride, o casal fará realizar na igreja Divino Espírito Santo da Bela Vista, à rua Frei Caneca,

\footnotetext{
${ }^{39}$ SÃO PAULO, Diário Oficial, Requerimento no 1074.52, 15 de setembro de 1952. pag.52-53

${ }^{40}$ SÃO PAULO, Diário Oficial, 14 de junho de 1949. pag.3
} 
missa em ação de graças, às 9 horas. Às 17 horas, o casal oferecerá aos seus amigos uma recepção à rua Marselhesa, $271 .^{41}$

Salathiel veria, ainda, a Copa de 1950. Certamente, experimentou a melancolia e a ressaca daquela derrota contra o Uruguai no Maracanã, como vemos em mais um trecho do texto do amigo anônimo:

"Salathiel sofreu, quando ainda combalido não resistira a emoção, a ver o Brasil cair vencido no Estádio do Maracanã, por ocasião da disputa da Copa do Mundo"42

Dada a sua trajetória, que apresentaremos nas próximas páginas desse trabalho, podemos imaginar a sua tristeza ao ver a culpa da derrota recair sobre os jogadores negros. Ainda pior para ele, conhecendo as opiniões do cronista, deve ter sido o argumento de que os negros não tinham envergadura moral para conseguir uma vitória pelo nosso país. Um homem dos esportes, militante do movimento negro, defensor da moral e da boa educação, um patriota por excelência, Salathiel deve ter ficado bastante amargurado e deprimido.

No dia 21 de dezembro de 1951, pouco depois do aniversário de seu filho Nestor, tendo o filho caçula, Pedro Paulo, acabado de completar seis anos, às vésperas de seu aniversário de casamento e também do Natal, Salathiel de Campos não resistiu às sequelas e faleceu. "Vitimado pelos azares do esporte" 43 , Salathiel viveu "do esporte, no esporte e para o esporte; morreu no esporte e pelo esporte!”. Foi “o filho dileto de uma geração que passa". ${ }^{44}$

\footnotetext{
${ }^{41}$ Jornal de Notícias, 23/12/1949, pag 7. Disponível em <http://bndigital.bn.gov.br/hemeroteca-digital/> Acesso em 30/06/2015.

A igreja, cercada pelas ruas Rua Frei Caneca, Barbosa Rodrigues e Peixoto Gomide, assim como a casa na Rua Marselhesa, na Vila Maraiana, ainda existem.

42 SÃO PAULO, Diário Oficial, Requerimento no 1074.52, 15 de setembro de 1952. pag.53.

${ }^{43}$ II Moscone, 25/12/1952 - pag 3

${ }^{44}$ Idem, ibidem.
} 


\subsection{Do nascimento à militância: o que sabemos sobre Salathiel de Campos?}

"Se nada é novo sobre a terra, por certo que nem tudo é egual. ${ }^{45 ",}$

Salathiel de Campos, 1939

Em Piracicaba, no dia 22 de Março de 1901, primeiro ano do século XX, uma sexta-feira, nascia a personagem que este trabalho se dedica a estudar. Viveria exatamente os primeiros cinquenta anos do século, tempo ao longo do qual construiu importantes contribuições para o esporte e para a inclusão da população negra na sociedade paulista, mas sem que isso tenha sido suficiente para que fosse lembrado pela História.

Quando nasceu, havia apenas treze anos desde a abolição da escravidão, e a República proclamada pelos militares, há apenas doze. Apenas dez anos antes, em 1891, havia sido promulgada a constituição que regeria o funcionamento da política restrita e patrimonialista da Primeira República. Cinco anos antes, o governo Republicano, comandado pelo paulista Prudente de Morais, combatera a comunidade de Canudos com a percepção, inflamada pela imprensa, de que se tratava de um movimento monarquista liderado por Antônio Conselheiro.

No mesmo ano do nascimento de Salathiel de Campos, foi erguido o Velódromo na rua da Consolação, em São Paulo, lugar que teria mais tarde o primeiro campo de futebol da cidade. Também foi o ano de fundação da Liga Paulista de Football, organizada pelos membros mais jovens da elite econômica e política paulistana. No dia de seu nascimento, o jornal O Commercio de São Paulo falava sobre a baixa do café, noticiava o resultado de alguns julgamentos, informava as mudanças no câmbio, anunciava o premiado por uma loteria, e em uma pequena nota falava sobre "Navegação aerea".

"O diretor da Cidade do Rio depositou (...) o relatório e desenhos do Aerostato Santa Cruz (...) Logo que seja concedido o privilegio, o modelo será exposto e o inventor iniciará a construção (...) com que presume ter, finalmente, dado solução a um dos problemas que mais preocupam e fascinam a humanidade" 46

\footnotetext{
${ }^{45}$ Correio Paulistano, 01/01/1939, Esportes, Ao Correr da Pena, pag. 16.

${ }^{46}$ Commercio de São Paulo, 22/03/1901, pag. 3. Disponível em <http://memoria.bn.br/DocReader/docreader.aspx?bib=227900\&pasta=ano\%20190\&pesq=>
} 
Pouco tempo depois, ainda em 1901, Santos Dumont rodearia a Torre Eiffel, em Paris, voando com seu dirigível N-6, ganhando com isso o Prêmio Deutsch. Algo notável para o Brasil, uma vez que, doze anos antes, na feira mundial na qual a referida torre foi apresentada como o grande marco da engenharia mundial, um símbolo da modernidade, os brasileiros expuseram uma muda de vitória régia ${ }^{47}$.

No ano seguinte, no Rio de Janeiro, o feito de Dumont virou tema de uma composição de Eduardo das Neves - famoso cantor, tocador de choros ao violão, autor e divulgador de lundus, modinhas, serestas e chulas, organizador de livros e protagonista da indústria fonográfica no Brasil - sua música mais celebrada:

"A velha Europa curvou-se ante o

[Brasil,

Terra, amada do indio audaz e guer-

[reiro.

A maior gloria do seculo XX

É Santos Dumont, um brasileiro"

A canção foi gravada junto da banda da Casa Edison, que assinaria contrato com o artista em 1902, e ele "passou a fazer parte, até o final da vida, do primeiro grupo de músicos profissionais dessa importante empresa de venda de partituras e discos, ao lado de Baiano, Cadete, Nozinho, Mário Pinheiro e Geraldo Magalhães"48. Se apresentava à população negra da época um espaço social possível, que seria depois estereotipado pelos brancos. No futebol, isso ainda não acontecia.

Começavam, na mesma época, a aparecer periódicos escritos, editados e publicados por cidadãos negros, movimento que seria mais tarde chamado pela academia de Imprensa Negra. Como listado por Flávio Gomes em Negros e Política, surgem: “o Treze de Maio (1888), o Exemplo (1892), A Redenção (1899), o Baluarte (1903), O Propugnador (1907)", e outros mais adiante, como "O Combate (1912), O Patrocínio (1913)". Salathiel de Campos colaborou, eventualmente, com os jornais O Combate, A Voz da Raça e o Clarim d'Alvorada - os dois últimos ligados à Frente Negra e ao Clube Negro de Cultura social, respectivamente.

Campos Sales (presidente entre 1898-1902) era presidente do Brasil, e conseguiu uma mudança no regimento interno da Câmara dos Deputados para que não mais se fizesse presidente o mais idoso dos eleitos, mas que se mantivesse o mesmo da legislatura anterior, tendo como resultado um congelamento do poder das oligarquias estaduais como

\footnotetext{
${ }^{47}$ Bureau Internacional des Expositions. Disponível em <http://www.bie-paris.org/site/fr/1889-paris>. Acesso em 09/05/2016. x

${ }^{48}$ Neto, Lira, Uma História do Samba: as origens, 2017
} 
configurado no momento da eleição. Seu sucessor, Rodrigues Alves (presidente entre 1902-1906), após a primeira eleição tocada a partir da política dos estados, consegue aprovar a Lei Rosa e Silva de reforma eleitoral, consagrando o voto aberto sem interferência da Justiça no processo de apuração, movimento que consagra as fraudes eleitorais típicas do período ${ }^{49}$.

Voltando à história de vida de nosso protagonista, Salathiel de Campos perdeu o pai nos seus primeiros dias de vida. A sua mãe, viúva, casou-se novamente, com um militar sobre o qual não se sabe muito, assim como não foram encontradas fontes sobre a mãe. Por conta da profissão do padrasto, em 1905, aos 4 anos de idade, Salathiel mudouse com a família de Piracicaba para Salto. Viveu, portanto, uma boa parte de sua infância no interior, até o fim da educação primária, por volta de $1910^{50}$.

Com uma nova transferência do padrasto, a família foi morar em São Paulo, não se sabe exatamente onde. Já na capital, estudou em uma escola salesiana, o Colégio Coração de Jesus, de nível elementar. Não temos grandes informações sobre sua vida nesse período, mas um inferência natural é que tenha trabalhado, como a maioria dos adolescentes pobres ou de classe média baixa da época. Como visto no seu pedido de aposentadoria de 1949, trabalhou em um Cartório de Hipotecas, especulamos que por volta dessa época, ainda adolescente.

Alfabetizado e, supõe-se, com alguma experiência profissional, em 1922, aos 21 anos, é contratado pelo Correio Paulistano como revisor, com "os incipientes conhecimentos de um autodidata" ${ }^{51}$. No ano seguinte, posto que já era um membro da imprensa paulista, seu nome começa a aparecer com certa frequência nas páginas dos jornais - como Salathiel, Sala, ou Thylba, apelido que, aparentemente, recebeu quando já trabalhava nas redações. Com isso sabemos, por exemplo, que em 1923 ele participou de uma prova de atletismo ${ }^{52}$, e também que passava longe de um exímio atleta. Seu talento era mesmo com a pena e o papel ${ }^{53}$.

Já com emprego fixo, casou-se em 24 de dezembro de 1924 com Celisa Vieira de Campos. Não se sabe a quanto tempo estavam juntos, mas a data do enlace é confirmada

\footnotetext{
49 SCHWARCZ, Lilia Moritz (coord.). Abertura para o mundo 1889-1930. Pg. 105

${ }^{50}$ SÃO PAULO, Diário Oficial, Requerimento no 1074.52, 15 de setembro de 1952. pag.52-53

${ }^{51}$ SÃO PAULO, Diário Oficial, Requerimento no 1074.52, 15 de setembro de 1952. pag.52-53

${ }^{52}$ A Gazeta, 14/08/1923. Disponível em <http://bndigital.bn.gov.br/hemeroteca-digital/>

${ }^{53}$ Correio Paulistano, 27/09/1926, pag 5. Disponível em <http://bndigital.bn.gov.br/hemerotecadigital/>
} 
pela notícia de bodas de prata encontrada em um jornal de 1949 ${ }^{54}$. Em 1925, com 24 anos de idade, casado, já empregado no Correio Paulistano e no São Paulo Esportivo, o Thylba passa a fazer parte também d'A Gazeta ${ }^{55}$. Provavelmente, vivia alguns dos melhores tempos de sua vida. A essa altura, já vemos completo o processo de inserção de Salathiel de Campos na modernidade negra, o processo tardio de incorporação da população negra que, no caso brasileiro, foi parcial, muito limitada, e só aconteceu por ação dos próprios negros "decididos a construir representações positivas para si e para a sociedade brasileira em geral" ${ }^{56}$. Salathiel de Campos é um dos grandes símbolos desse momento.

Voltando à sua biografia, um fato importante deste início de carreira que nos ajuda a entender sua trajetória é que cobria o futebol varzeano e do interior, tanto no Correio Paulistano quando n'A Gazeta ${ }^{57}$, atividade na qual ele era considerado um dos "membros mais proeminentes" ${ }^{\text {"58 }}$. Não é possível afirmar que essas eram suas atribuições por ser considerado um jornalista de segundo escalão, nem que sua pele negra o tenha relegado à cobertura de atividades esportivas menos nobres. É possível, e até provável, que Salathiel de Campos fosse envolvido com o futebol de várzea antes mesmo de começar sua carreira. Parece caricato que o redator negro fosse responsável por cobrir o futebol de várzea, mas o que vemos é que a várzea é a base de todo seu pensamento, é de importância vital para todo o seu posicionamento posterior. A várzea é amadora, é, na visão dele, essencialmente brasileira, e é inclusiva, integra os negros, como ele gostaria que o futebol oficial (se mantendo amador) também fizesse.

As redações da imprensa branca eram, certamente, diferentes da várzea nesse aspectos. As evidências apontam para uma integração apenas relativa dele com seus colegas. Mas, de uma forma ou de outra, ele se integra. Logo aparece como uma de três exceções, junto a outros dois jornalistas esportivos, em uma prova exclusiva aos empregados da Cia. Telephonica, disputada na Avenida Paulista. Salathiel Campos como corredor era um ótimo jornalista, e assim correu a prova nos últimos lugares, no último pelotão. No ano seguinte, os jornalistas, Salathiel incluso, arbitrariam a mesma prova.

\footnotetext{
54 Jornal de Notícias, 23/12/1949, pag 7. Disponível em <http://bndigital.bn.gov.br/hemeroteca-digital/>

${ }^{55}$ A Gazeta, 22/12/1925, Factos e Boatos. Disponível em <http://bndigital.bn.gov.br/hemerotecadigital/>

${ }^{56}$ GUIMARÃES, 2003 in: FERREIRA, Maria Cláudia. Espaços de sociabilidade e ações anti-racismo no cotidiano das elites negras na cidade de São Paulo: busca por projeção individual e legitimidade de grupo (1900-1940). Revista Mosaico, no 3, ano II, 2010. Pag.2

${ }^{57}$ A Gazeta, 30/12/1926, pag 7. Disponível em <http://bndigital.bn.gov.br/hemeroteca-digital/>

${ }^{58}$ A Gazeta, 26/05/1927, pag 7. Disponível em <http://bndigital.bn.gov.br/hemeroteca-digital/>
} 
Participou também, como concorrente, na prova Esportistas da Penna. "O prego do Thylba (...) anda até fazendo massagens electricas para a desenvoltura dos musculos”, dizia uma nota d'A Gazeta. A inscrições dessa prova, anunciadas em 26 de abril de 1926, eram direcionadas a Salathiel de Campos. O jornal instruía os interessados a procurá-lo na seção esportiva do jornal, das 13 às 16 horas, ou, também na seção esportiva, no São Paulo Jornal, das 17 às 20 horas $^{59}$. Por fontes como essas podemos conhecer melhor a rotina de trabalho deste jornalista.

Salathiel mereceu até manchete quando decidiu jogar com os Esportistas da Penna no basquete:

\section{“THYLBA VAE JOGAR! \\ Outro que adhere}

O popular chronista varzeano, Thylba (Salathiel de Campos) a exemplo de muitos outros, tambem vae praticar o popular esporte do "quintetto", defendendo as côres dos "Esportistas da Penna" 60.

Ora chamado de "prego", ora de "popular chronista", ele parece integrado ao grupo, o que não é absurdo se pensarmos que Salathiel de Campos já fazia parte de uma classe média negra em formação, não era um negro pobre como a maioria, e isso o garantia algumas aberturas nos espaços majoritariamente brancos.

Para entender essa distinção de "tipos" de negros e entender melhor Salathiel de Campos, convém lembrar que havia uma grande divisão entre a população negra. Salathiel de Campos foi um dos militantes da modernidade negra - como explicada por Guimarães $^{61}$ - e aproveitou sua posição e sua profissão para cavar trincheiras nos campos esportivo e político, isso é fato. Mas isso fazia dele um negro de elite, era um meio de luta por inclusão mas também um fator de distinção.

O jornalista já estava ambientado e tomava a frente em eventos esportivos, reuniões de cronistas e encontros sociais. Morava à rua Siqueira Campos, 42, na Liberdade, que à época era um bairro de negros e imigrantes, e ali, certamente já alcançava algum destaque, uma vez que:

\footnotetext{
${ }^{59}$ A Gazeta, 26/04/1926. pag 5. Disponível em <http://bndigital.bn.gov.br/hemeroteca-digital/>

${ }^{60}$ A Gazeta, 26/01/1926. pag 5. Disponível em <http://bndigital.bn.gov.br/hemeroteca-digital/> ${ }^{61}$ GUIMARÃES, 2003 in: FERREIRA, Maria Cláudia. Espaços de sociabilidade e ações anti-racismo no cotidiano das elites negras na cidade de São Paulo: busca por projeção individual e legitimidade de grupo (1900-1940). Revista Mosaico, no 3, ano II, 2010.
} 
" 'O fato de saber ler e escrever, freqüentar eventos na cidade, usar roupas finas, ter um emprego fixo, etc., agregava prestígio e promovia distinção social. Essa elite negra buscava uma "identidade de grupo fundada em valores e símbolos, diferente dos negros pobres dos porões'. (SILVA, 1990: 108). Ou melhor, procurava, a partir da assimilação dos padrões culturais burgueses e citadinos, logo modernos, serem identificados como tão capazes quanto os brancos de viver os valores e espaços criados pela modernidade. "62

Essa seria uma marca de Salathiel de Campos e, se o leitor tiver que se lembrar de uma coisa antes de continuar a leitura do texto, que seja isso: a ambição de assimilar padrões culturais burgueses e ser identificado como tão capaz quanto os brancos de viver valores e espaços da modernidade. O futebol era um desses espaços de sociabilidade modernas, como mostra Wilson Gambeta em A Bola Rolou. Este autor mostra que as parentelas paulistanas, conceito que resume as relações estreitas e em rede das famílias ricas de São Paulo, traziam da Europa as coqueluches do momento, passando pelas corridas de cavalo, pelo ciclismo, pela corrida de automóveis, e o futebol. Salathiel de Campos queria participar, e participou de fato, desse espaço.

Do outro lado dessa divisão, temos os negros pobres, aqueles que, por diversos motivos, não haviam entrado na modernidade negra. Aqueles que, diferente de Salathiel de Campos, não tiveram a renda familiar proporcionada por um padrasto militar, a educação elementar, um primeiro emprego que não fosse braçal, etc. Falamos de um período no qual boa parte da população não tinha contratos formais de trabalho e exercia atividades insalubres, não muito diferentes do período da escravidão ${ }^{63}$. Essa divisão também se manifestava em um espaço familiar a Salathiel de Campos, a várzea.

O Clube Atlético Paulistano, que à época integrava o chamado futebol oficial, é o exemplo maior da elite paulistana. Anatol Rosenfeld chega a opor este clube à várzea devido à constante evocação de um ethos aristocrático ${ }^{64}$. Apesar desta oposição não ser absurda e ter se sustentando na literatura durante muito tempo, a várzea não era homogênea. Era reproduzida ali a divisão entre negros pobres e negros de elite. Havia

\footnotetext{
62 FERREIRA, Maria Cláudia. Espaços de sociabilidade e ações anti-racismo no cotidiano das elites negras na cidade de São Paulo: busca por projeção individual e legitimidade de grupo (1900-1940). Revista Mosaico, no 3, ano II, 2010. Pag.4

63 Idem, pag3.

${ }^{64}$ SILVA, Diana Mendes Machado da. A Associação Atlética Anhanguera e o futebol de várzea na cidade de São Paulo (1928-1950) [doi:10.11606/D.8.2013.tde-29102013-113153]. São Paulo : Faculdade de Filosofia, Letras e Ciências Humanas, Universidade de São Paulo, 2013. Dissertação de Mestrado em História Social. [acesso 2018-05-04]. Pag 105.
} 
negros jogando em diversos clubes da várzea, em geral negros pobres, e havia clubes formados apenas por negros, como o União Futebol Clube, o Clube Royal e o São Geraldo Futebol Clube ${ }^{65}$, sendo que este último era um clube exclusivo da elite negra. Era o Paulistano dos negros. ${ }^{66}$

Ainda nos falta descobrir, portanto, a que várzea Salathiel de Campos se referia, qual várzea dava sustentação às suas ideias. A várzea de forma geral, o conceito de várzea como um espaço livre, inclusivo e de prática amadora; ou a várzea como espaço de sociabilidade de uma elite negra, que emulava os clubes de elite?

Seja como for, podemos encerrar aqui a primeira parte de nossa narrativa. Temos que Salathiel de Campos nasceu no interior, em Piracicaba, ficou órfão de pai ainda bebê, mudou-se para outra cidade do interior acompanhando o padrasto militar. Aos 10 anos chegou à capital, estudou em colégio católico, provavelmente trabalhou em cartório ainda na adolescência, entrou na carreira jornalística aos 21 anos, conquistou espaço em vários veículos da imprensa, e se integrou aos colegas "da penna".

Após uma dupla inclusão, primeiro à elite negra e, depois, à imprensa branca, Salathiel de Campos circulava entre os campos político e esportivo. Este último, seguindo Toledo ${ }^{67}$, entendemos como dividido entre três grandes áreas: especialistas (jornalistas, estudiosos acadêmicos), profissionais (treinadores, atletas, preparadores) e torcedores. Salathiel de Campos era, portanto, agente dos campo esportivo (e político) no ramo dos especialistas, mais especificamente como um redator (e, depois, chefe de redação) de um jornal impresso. É natural, então, que sua ação fosse realizada, essencialmente, por meio de seus textos, o que é ainda mais importante se lembrarmos que tratamos de uma época sem televisão, internet, e com o rádio ainda no início de sua era de ouro. O jornal era, de fato, o principal meio de comunicação entre a população letrada ${ }^{68}$.

Com o que veremos, podemos atestar a participação do movimento na entrada de pessoas negras no campo esportivo. Salathiel de Campos foi mais um pensador da questão

\footnotetext{
65 Idem. Pag 83.

${ }^{66}$ Agradeço a José Paulo Florenzano por esta importante contribuição, a reflexão sobre a heterogeineidade da várzea, que também se dividia assim como o campo negro estava dividido, acrescentou muito a este trabalho.

${ }^{67}$ TOLEDO, Luiz Henrique de. Lógicas no Futebol. São Paulo: Hucitec/Fapesp, 2002.

${ }^{68}$ Segundo consta, Salathiel de Campos atuou também no rádio, atuação essa que não foi estudada por este trabalho, mas que merece ser estudada. A começar, claro, por encontrar essas fontes.
} 
racial no Brasil, mas mostra, como dito na epígrafe, que "se nada é novo sobre a Terra, nem tudo é igual"'.

\subsection{Um cronista respeitado}

O ano de 1926 é importantíssimo na história de Salathiel de Campos. São encontrados cada vez mais registros do cronista em eventos sociais ${ }^{69}$, esportivos, de textos assinados - como Thylba - no Sacy Desportivo ${ }^{70}$, caderno de esportes do jornal O Sacy, e matérias no Correio Paulistano (também como Thylba). Nesse ano, além de publicar suas primeiras matérias assinadas, participa, por meio do jornal A Gazeta, de uma campanha pela convocação de atletas negros à seleção paulista de futebol e lança uma compilação sobre ciclismo e motociclismo. Um desempenho digno de nota, se lembrarmos que ele exercia a profissão há apenas cinco anos.

A essa altura, identificamos na biografia de Salathiel de Campos o início da formação do que Gramsci chama de intelectual orgânico. Melhor explicando: havia, nesse momento e ao longo de toda a carreira de Salathiel de Campos, um embate pela direção política e intelectual do país. A essa direção, sempre em disputa, Gramsci dá o nome de hegemonia. O intelectual orgânico é aquele que está direta e intimamente ligado à sua classe e que ajuda a organizar a sua hegemonia. No caso gramsciniano, de linha marxista, é utilizado o conceito de classe, mas a ideia pode ser transposta, mas utilizando aqui o conceito de raça.

Como está sendo mostrado, Salathiel de Campos havia passado por uma dupla inclusão (à elite negra e à imprensa branca), ainda que não fosse rico, proprietário, ou mesmo parte da elite política, também já não era mais parte da parcela mais pobre, que vivia desempregada ou de trabalhos braçais. Sendo assim, o que unia Salathiel de Campos aos outros tantos cuja hegemonia ele ajudava a organizar era o conceito de raça. Foi um intelectual orgânico da raça negra brasileira, que atuou principalmente no campo esportivo.

Sobre essa atuação, seguiremos na ordem. Primeiro, no dia 15 de julho de 1926, é anunciada a publicação de Salathiel de Campos, , então com 25 anos de idade, que

\footnotetext{
${ }^{69}$ A Gazeta, 05/02/1926, pag 6. Disponível em <http://bndigital.bn.gov.br/hemeroteca-digital/>

${ }^{70}$ Salathiel de Campos publicou textos em O Sacy entre janeiro e abril de 1926. Disponível em $<$ http://bndigital.bn.gov.br/hemeroteca-digital/>
} 
começou a pavimentar a sua carreira como escritor, além de jornalista. Trata-se da compilação CYCLISMO - o cyclismo e o motocyclismo na vida esportiva paulista:

"Compilado por Salathiel de Campos, conhecido chronista esportivo, e nosso companheiro de trabalho, apparecerá brevemente um livro sobre cyclismo e motocyclismo, subordinado áquelle titulo. Inutil será dizer, que por certo o nosso companheiro obterá um sucesso com seu trabalho, pois ele virá sanar uma lacuna em nossos meios esportivos." 71

Não foram encontradas até o momento em que esta dissertação foi escrita fontes sobre a repercussão dessa publicação. Nos importa é que desde o início de sua carreira, Salathiel de Campos dava contribuições intelectuais no campo esportivo da época. Esta publicação nos ajuda a entender uma outra, o seu livro mais importante: $O$ Homem Negro no Esporte Bandeirante. Com esse retrospecto, entendemos que a publicação desta obra (em 1934) não foi uma concessão, mas um espaço conquistado aos poucos e com trabalho.

Logo em seu primeiro ano de matérias assinadas, Salathiel de Campos publica um texto muito mais interessante para o tema desta pesquisa, o Bloco dos Caboclos:

"Os blocos esportivos estão pondo as manquinhas de fóra. Todo o dia surge ahi um conjunto tira-prosa (...) Agora surge o tremebundo Blôco dos Caboclos, o qual tem a sua tenda na zona de Tucuruvy (...) Os pedestrianos em questão são moradores do logar, serranos rijos como mourões de cera, com folego de sete garotos angorás. $O$ caboclo brasileiro, não obstante a creação do molengo Géca, é de uma resistência physica pasmosa. Possue por natureza, 'material' de verdadeiro athleta. A questão é treinal-o. Treinal-o moral e physicamente. É isso o que se propõe a fazer o capitão do Blôco dos Cablocos [sic] (...)

Matheus Marcondes, o formidável triumphador da Marathona Paulista (...) prometeu treinar algumas vezes a turma sertaneja. "72

Desse texto, conseguimos extrair elementos importantíssimos.

Primeiro: Salathiel de Campos falou sobre a tendência de criação de blocos esportivos e mostrou que os chamados "caboclos" buscavam seu espaço. Essa luta por

\footnotetext{
${ }^{71}$ A Gazeta, 15/07/1926, pag 7. Disponível em <http://bndigital.bn.gov.br/hemeroteca-digital/>

${ }^{72}$ A GAZETA, 26/07/1926, pag 7. Disponível em <http://bndigital.bn.gov.br/hemeroteca-digital/>
} 
participação é muito importante aqui, por ser parte de uma agência "de baixo para cima", que pode enquadrar esse processo que descrevemos na chamada History from below, uma história a contrapelo - cujo expoente mais conhecido é Edward Thompson.

Em segundo lugar, o jornalista apresentou aquele que será o principal argumento de todos seus principais textos: o caboclo brasileiro (ou o negro, ou o sangue negro, ou a negritude) tem, segundo ele, uma resistência física acima do normal, um atleta por natureza para quem basta apenas treinamento moral e físico. Daí a importância, para ele, do Bloco dos Caboclos, que fornecia esse treino necessário à manifestação das qualidades ditas inatas.

Além disso, Salathiel de Campos demonstrava clareza a respeito de seu lugar na disputa da hegemonia a respeito da direção intelectual e política do país a respeito da raça. Falava sobre as supostas qualidades inatas ao caboclo em oposição ao darwinismo social da época, manifestado por eugenistas como Monteiro Lobato, citado por ele, que tinha espaço de sobra para emitir suas opiniões, seja em seus livros ou nos jornais em que trabalhou, como O Estado de São Paulo, onde publica o artigo Urupês, "dando vida ao famoso personagem Jeca Tatu"73. Campos marcou sua posição ao dizer que o "caboclo brasileiro, não obstante a creação do molengo Géca, é de uma resistência physica pasmosa. Possue por natureza, 'material' de verdadeiro athleta". O Jeca Tatú é “creação" a qualidade física inata simplesmente "é".

Por último, mas não menos importante, esse texto já apresentava uma figura que será de extrema importância como referência e símbolo de sucesso: Matheus Marcondes. Este atleta negro aparece também em O Homem Negro no Esporte Bandeirante e em diversas colunas de Salathiel de Campos nos anos 30. Como dito, o campeão negro "prometeu treinar algumas vezes a turma sertaneja", e isso é muito relevante. Havia entre a população negra a ideia de multiplicação do conhecimento, como ficará evidente quando formos tratar das ações educativas da Frente Negra Brasileira. Aqui, temos um caso esportivo dessa multiplicação. Se basta treino "moral e physico" para que os negros (e caboclos) tenham sucesso, aqueles que já alcançaram excelência deviam ensinar os que ainda estavam em sua busca.

\footnotetext{
${ }^{73}$ Acervo Estadão, Personalidades, Monteiro Lobato. Disponível em <http://acervo.estadao.com.br/noticias/personalidades,monteiro-lobato,1023,0.htm>
} 
Dizer que Salathiel de Campos deveria problematizar a questão, como fazemos hoje, seria um anacronismo. Seu argumento das "qualidades inatas" do negro é típico de sua época, e tem sua importância, dado que oferece oposição aos argumentos eugenistas. Antes da inclusão, era necessária a afirmação da raça. Por outro lado, é interessante engraçado, até - o desempenho esportivo do próprio Salathiel de Campos, que no mesmo ano de 1926 ficou em 68 no "Circuito de Villa Mariana" (também conhecido como último lugar). O que rendeu ao cronista como "premio-consolação, uma camisa de lã e seda, oferecida pelo Sr. Max Emiliano Merigo"74. Uns negros ganham medalhas, outros ganham camisas de lã, é normal que seja assim. Salathiel de Campos poderia dizer que a ele faltou ao treino que pudesse despertar suas qualidades inatas, e assim manteria sua coerência. De qualquer forma, falamos de um período no qual o ato político mais importante era afirmar, ainda que exageradamente, as qualidades da raça.

Talvez tenha desistido de competir, ou talvez preferisse ficar nos bastidores. Fato é que nas competições esportivas seguintes ele não atuou como atleta, mas como patrocinador e fiscal - prova Graves Vermelhos ${ }^{75}$-, como organizador - Taça Gazeta $^{76}$-, ou como juiz - Corrida de São Silvestre, promovida pela Gazeta, "o sensacional prélio" que vinha "despertando interesse fora do comum em nosso mundo esportivo"77. Não era um atleta, mas alguém que teve no esporte uma grande paixão, envolvido em diversas modalidades ao longo de toda sua carreira.

\subsection{Militância no jornal A Gazeta (1926)}

Já falamos a respeito da publicação sobre ciclismo e da primeira coluna assinada por Salathiel de Campos, mas o fato mais marcante de 1926 ainda estava por vir. Apesar de ser um importante acontecimento da história de São Paulo, justamente por ainda não ter sido estudado a fundo, esta campanha não tem um nome. Por isso, nos referimos a ela descrevendo o que foi: uma campanha pela convocação de jogadores negros à seleção

\footnotetext{
${ }^{74}$ Correio Paulistano, 27/09/1926, pag. 5. Disponível em <http://bndigital.bn.gov.br/hemerotecadigital/>

${ }^{75}$ A Gazeta, 08/11/1926. Disponível em <http://bndigital.bn.gov.br/hemeroteca-digital/>

${ }^{76}$ A Gazeta, 21/12/1926. Disponível em <http://bndigital.bn.gov.br/hemeroteca-digital/>

${ }^{77}$ A Gazeta, 31/12/1926. Disponível em <http://bndigital.bn.gov.br/hemeroteca-digital/>
} 
paulista. Não tendo a ambição de querer batizar esse importante momento da militância brasileira, seguiremos.

A mobilização se deu pela via impressa na coluna Écos na seção de Futebol d'A Gazeta, e se expandiu para fora das páginas dado o antagonismo da Associação Paulista de Esportes Atléticos (sobre a qual falaremos mais adiante), que certamente mantinha alguma relação com as redações paulistanas por meio de seus próprios agentes. Os textos não são assinados, mas sabemos por várias fontes (já elencadas antes) que Salathiel de Campos trabalhava no caderno de esportes do jornal nessa época, chefiado então por Leopoldo Sant'Anna, e que participou da redação dessa coluna.

Tanto o chefe de redação quanto o próprio Salathiel de Campos concordavam que o melhor caminho para o esporte era o amadorismo, diferente do sucessor, o ítalobrasileiro Thomaz Mazzoni, que assumiu a chefia da redação esportiva em 1930, ferrenho defensor do profissionalismo. Outra diferença importante é a participação na militância. Sant'Anna, como Salathiel de Campos conta em seu livro O Homem Negro no Esporte Bandeirante, já havia militado nas páginas d'A Gazeta pela entrada de jogadores negros nos times do chamado futebol oficial em fins dos anos 10 e início dos anos 20. Mazzoni, por outro lado, nunca comprou essa briga.

Salathiel de Campos teve oportunidade de trabalhar, também, com Mazzoni como vemos no texto Descendo a serra em uma visita de observação, quando o jornalista visitou Santos pela Gazeta, em 1933. Nessa época, o Correio Paulistano ainda estava fechado por decreto de Getúlio Vargas durante o Governo Provisório (1930-1934). À época, Clube Atlético Santista, hoje abandonado e à beira da falência, construía um campo na Ponta da Praia e os jornalistas foram convidados a ver "o vulto da grande obra que o clube está construindo". Ao listar os redatores paulistanos, Salathiel de Campos aparece como representante de Mazzoni, seu chefe. Há uma série de peripécias descritas na reportagem: um dos carros para de funcionar na subida da serra, alguns cronistas esperam pelos companheiros no bar Curva da Morte, dando um “epilogo humorístico" à "excursão dos chronistas"78.

Juntos, Mazzoni e Campos viajaram ao Rio de Janeiro, no mesmo ano de 1933, acompanhando a seleção paulista que embarcara à capital para enfrentar a seleção da Liga

\footnotetext{
${ }^{78}$ A Gazeta, Descendo a serra em uma visita de observação, 24/02/1933.
} 
Carioca de Futebol ${ }^{79}$. Sabemos, então, que um conhecia o outro, tendo trabalhado e inclusive viajado juntos. Que reconhecia o bom trabalho de Campos também sabemos. No Almanach Esportivo de 1928 na seção "Nossos Chronistas", Mazzoni escreve:

"Salatiel de Campos (Tylba) - Um dos directores do S. Paulo Sportivo, tendo feito parte da "Gazeta". Pertence actualmente ao "Combate" sobresahindo-se na chronica de varios esportes, que o tornaram dos mais populares. "80

Resta saber a razão pela qual o jornalista ítalo-brasileiro não citou os textos de Salathiel de Campos em nenhuma de suas obras. É certo que discordavam na maior parte dos assuntos (como veremos no Capítulo 3), mas seria leviano ignorar a produção do colega de trabalho apenas por isso. Havia também como plano de fundo dessa questão a rivalidade entre negros e italianos, historicamente construída desde o início da migração, simultâneo ao movimento abolicionista e aos primeiros anos da abolição, e que chegou ainda acirrada nos anos 30. Nos empregos no campo ou na indústria, os italianos eram privilegiados, nas pensões, os italianos ocupavam o térreo e os andares altos enquanto os negros ficavam nos porões. Não especificamente vinculada à população negra, mas aos brasileiros pobres de forma geral, essa oposição também se manifestava no futebol com a rivalidade entre Palestra Itália (depois Palmeiras) e Corinthians.

Se a relação entre Salathiel de Campos e o Thomaz Mazzoni foi influenciada por essa questão, não podemos ter certeza. O que não resta dúvida é que, entre outras razões, não ter sido citado pelos principais autores da época (Mazzoni e Mario Filho depois dele), fez Salathiel de Campos passar tanto tempo esquecido.

Nos adiantamos à época de Mazzonni n'A Gazeta, mas agora devemos voltar à Leopoldo Sant'Anna. Só assim fecharemos esse enorme parêntesis para falar da campanha de 1926. Abro espaço para que Salathiel de Campos explique melhor o que foi este ato de militância, aproveitando um trecho do livro $O H N E B$ :

"Veiu o Campeonato Brasileiro de Futebol de 1926 e o momento era azado para uma campanha pró-negros. Alguns orgams da nossa imprensa, embora os seus redactores esportivos nos dissessem sympathicos aos negros, não focalizaram a questão.

\footnotetext{
${ }^{79}$ A Gazeta, 08/04/1933.

80 MAZZONI, Thomaz. Almanach Esportivo. São Paulo, 1928. pag. 295.
} 
Preferiram o silencio. Mas elle foi thermometro para medir até onde ia a sinceridade desses jornalistas.

Defeitos de educação, talvez.

Militando na imprensa, era natural que profligassemos a insistencia dessa mentalidade de preconceitos de côr.

Fizemos, então, das columnas da A Gazeta', a nossa tribuna, na focalização diaria de factos que punham a descoberto a esquivancia dos mentores officiaes em chamar para os treinos os negros. " 81

É importante ressaltar, desde já, que a campanha esteve concentrada nos negros em grande forma, aqueles sobre os quais não pairava qualquer dúvida a respeito de suas qualidades. Assim, não haveria outra razão a não ser o preconceito para que não fossem convocados: Petro, Giby e Bisoca - do Syrio - Augusto Americo e Mellinho- do Velo Clube de Rio Claro. Mas a luta não seria fácil, uma vez que:

"Cahiram sobre o negro os mais fortes doestos, as accusações mais pesadas, culminando com a affirmativa de que a presença de negros na selecção paulista iria diminuir o efeito moral da nossa situação. "82

Ainda no livro O Homem Negro no Esporte Bandeirante, Salathiel de Campos cita o exemplo de David, um jogador negro do Botafogo, equipe de várzea de São Paulo:

"O melhor da varzea, e os entendidos affirmavam ser elle, depois do grande Rubens Salles, então no apogeu de suas glorias, o melhor centro-médio que São Paulo possuia. E esse authentico campeão não pudera ingressar officialmente no Corinthians porque a liga e associações paulistas não lhe permittiam, por ser negro!" 83

Esse objetivo político de inclusão racial não estava tão claro em 1926 quanto estaria 1934, quando Salathiel de Campos publicou em seu livro estes trechos que acabamos de destacar. O objetivo parecia estar claro para os jornalistas da Gazeta, mas em seus textos a argumentação era construída em torno do desempenho da seleção

\footnotetext{
${ }^{81}$ Correio Pauistano, Caderno de Esportes, O homem negro no esporte bandeirante, 16/10/1934. Pag.8

${ }^{82}$ Correio Pauistano, Caderno de Esportes, O homem negro no esporte bandeirante, 03/11/1934. Pag.7

${ }^{83}$ Correio Pauistano, Caderno de Esportes, O homem negro no esporte bandeirante, 06/10/1934.

Pag.11, rodapé.
} 
paulista e dos problemas identificados como causas de sua suposta decadência. Essa abordagem, que podemos considerar cuidadosa, provavelmente aconteceu porque Salathiel de Campos ainda não tinha o respaldo da Frente Negra Brasileira para falar abertamente sobre preconceito racial - o Centro Cívico Palmares foi fundado nesse mesmo ano, porém era mais um espaço de sociabilidade do que uma organização política $^{84}$. E também, como disse Salathiel, porque esse assunto era (como ainda é) uma caixa de marimbondos.

\subsubsection{As disputas entre seleções estaduais}

A partir de 1922, mesmo ano que Salathiel de Campos ingressou na imprensa paulista, passaram a ser organizados campeonatos entre seleções estaduais de futebol. As ligas e associações escolhiam, cada uma à sua maneira, jogadores entre os vários clubes e formavam seus selecionados. As seleções paulista e carioca eram as mais fortes e, justamente por isso mas também pela oposição histórica entre os provincianos paulistas e a então capital do país, construíram a maior rivalidade. Essa competição, algo como uma copa de federações, consolidou o poder das federações estaduais sobre o futebol de suas regiões.

Antes de seguirmos com a história das disputas, é importante entender melhor o cenário do futebol paulista, dividido então entre a Liga dos Amadores de Futebol (LAF) e a Associação Paulista de Esportes Atléticos (APEA) - cenário que, de forma parecida, se repetia em outros dos principais centros do futebol brasileiro, como o Rio de Janeiro e o Rio Grande do Sul.

O futebol se desenvolveu no Brasil entre escolas religiosas e práticas esportivas de uma juventude aristocrática, como um símbolo de adesão à modernidade, uma moda equiparável ao ciclismo ou, antes, ao turfe ${ }^{85}$. Em poucas décadas, este esporte passou a fazer parte de um campo esportivo maior e mais complexo, com as típicas disputas por poder e influência. A constituição de torcidas e a transformação de uma prática esportiva dos sportsman em um espetáculo de atletas acrescentaram novas camadas a esse campo.

\footnotetext{
${ }^{84}$ Ainda não entramos detalhadamente na formação dos espaços de sociabilidade da população negra, muito menos dos vários movimentos negros dos anos 30. O faremos mais adiante, quando os alcançarmos no tempo. Chegando lá, voltaremos um pouco para os anos vinte, tratando finalmente desses assunto.

${ }^{85}$ Sobre os primeiros anos do futebol no Brasil, é importante a leitura de: GAMBETA, Wilson. A bola rolou: o velódromo paulista e os espetáculos de futebol. São Paulo: SESI-Editora, 2015.
} 
A primeira entidade do futebol paulista havia sido a Liga Paulista de Football, fundada em 14 de dezembro de 1901, pioneira na organização do que já àquela altura se chamava Campeonato Paulista. Essa liga era notadamente elitizada, representa perfeitamente a imagem que temos, atualmente, do futebol no início do século XX. A narrativa de que o futebol brasileiro, no início, era restrito à elite se baseia, no caso de São Paulo, na atuação da Liga Paulista de Football. Como podemos constatar ao ver a lista de clubes fundadores (todos eles de elite): como fundadores as equipes do São Paulo Athletic Club, Associação Atlética Mackenzie College, Sport Club Internacional, Sport Club Germânia e o Clube Atlético Paulistano.

Uma década depois, o cenário era completamente outro. Não se tratava mais de times de setores diferente da elite paulistana se enfrentando, de forma simbólica, por meio do futebol. Aristocratas paulistanos de famílias tradicionais (Clube Atlético Paulistano), contra os ingleses (São Paulo Athletic Club), contra os imigrantes (Sport Club Germânia). A essa altura, tratava-se de um esporte consolidado, com diversos outros clubes na capital e no interior, campeonatos, torcidas, rivalidades...e dinheiro. É o já tão falado processo de mercantilização do futebol, simultâneo a outro processo também bastante conhecido: a popularização do futebol.

Em decorrência dessas disputas, em 1913 é fundada uma associação dissidente da LPF, a Associação Paulista de Esportes Atléticos (APEA). Dois clubes lideraram a dissidência: o Paulistano e a Associação Atlética Palmeiras ${ }^{86}$. No primeiro campeonato, participam apenas os fundadores e o time do Mackenzie. Mais tarde, a partir de 1917, ganha força ao trazer para seus campeonatos clubes como o Corinthians, o Palestra Itália, o Santos, a Portuguesa, o Guarani, entre outros.

Nesse contexto, já a partir dos anos vinte, há o que se convencionou chamar de profissionalismo marrom. Como o futebol é disputado por jogadores (ou, mais tarde, atletas), e estes atraem torcida e bons resultados, estes passaram a ser também objeto de disputa. Para tanto, clubes ofereciam o "bicho" e outros tipos de bonificações. Para os defensores do amadorismo, do esporte pelo esporte (ou por amor ao esporte), receber para jogar era um absurdo. Para os defensores do profissionalismo, era um processo normal, que modernizaria o futebol e o levaria a um outro patamar. Estava formada a polêmica.

\footnotetext{
${ }^{86}$ Não relacionada ao atual Palmeiras, que na verdade começa sua história como Palestra Itália.
} 
A maioria dos membros da APEA tendia a ser favorável ao profissionalismo. O Clube Atlético Paulistano, por princípio e por tradição um clube defensor do amadorismo, decide deixar a associação. Como disse Joel Rufino dos Santos:

"Os atletas e dirigentes contrários à popularização do esporte recusavam receber e pagar um centavo que fosse. Temiam a morte do 'verdadeiro espírito olímpico'. No fundo, defendiam uma posição de classe, eram burgueses, com negócios e empregos, ameaçados pela invasão proletária. No seu entender, devia-se jogar unicamente por amor á camisa, nunca por dinheiro. " 87

Mais uma vez liderando uma dissidência, como já fizera em 1913, o CAP fundou a Liga dos Amadores de Futebol (LAF) em 1926 - justamente o ano da campanha realizada n'A Gazeta por Salathiel de Campos e Leopoldo Sant'Anna que descreveremos mais à frente. Essa liga teve curta duração, e acabou (em 1930) antes mesmo do profissionalismo ser oficializado (1933). É justamente quando o Paulistano decide se retirar do futebol - ao menos do futebol oficial.

Feitas as apresentações, é importante chamar atenção para o fato de que a campanha de 1926 acontece justamente no momento de maior tensão entre amadorismo e profissionalismo, quando a dissidente LAF foi fundada e começou a fazer oposição à APEA. Enquanto se desenrolavam essas disputas por poder no campo esportivo de forma geral, e no futebol, em particular, aconteciam também os campeonatos interestaduais.

Na primeira edição, em 1922, disputaram o título as federações de: São Paulo, Bahia, Rio Grande do Sul, Rio de Janeiro, Distrito Federal, Paraná e Minas Gerais - Pará e Pernambuco desistiram de participar. No dia 13 de agosto, na Chácara da Floresta, em São Paulo, os paulistas foram campeões com uma vitória por 4 a 1 contra o Distrito Federal - gols de Rodrigues, Neco e dois de Friedenreich.

No ano seguinte, além dos pioneiros, Pará e Pernambuco também participaram. A campanha da seleção paulista acumulou vitórias, começando com um 4 a 1 contra o Rio Grande do Sul, 5 a 1 contra o Paraná, e na final, contra o Distrito Federal como no ano anterior, vitória por 4 a 0 - três gols do caipira mestiço Tatu e um de Feitiço.

\footnotetext{
${ }^{87}$ SANTOS, Joel Rufino dos (Org.). História política do futebol brasileiro. São Paulo: Brasiliense, 1981. Pag47.
} 
Com vitórias indiscutíveis logo nos primeiros embates nacionais do futebol brasileiro, os paulistas estavam certos de que eram superiores. Nas palavras de Salathiel de Campos:

"As continuas e esmagadoras victorias sobre os cariocas, as lutas
emocionantes entre os três grandes clubes pela collocação no
campeonato local, tudo isso despertava no nosso povo um
enthusiasmo invulgar." 88

Porém, na terceira edição dessa taça, em 1924, os cariocas foram campeões, vitória por 1 a 0 contra São Paulo na final. Em 1925, nova derrota, também para os cariocas. Novos participantes entraram na competição, como Espírito Santo, Amazonas e Paraíba, a fórmula foi alterada para um formato com duas fases de grupo e final em dois jogos, ao invés de um. No caminho até a final, São Paulo goleou o Paraná por 6 a 1, o Rio Grande do Sul por 4 a 0 e o Pará por 3 a 0. Os cariocas ganharam de 6 a 0 do Espírito Santo, de 3 a 0 de Minas Gerais e 2 a 0 da Bahia. Na final, um 3 a 2 após um empate em 1 a 1 no primeiro jogo deixou o título novamente com os cariocas.

Esse é o contexto que era necessário explicitar antes de narrar os acontecimentos da campanha de 1926 n'A Gazeta. O campo esportivo paulista rachado entre defensores do profissionalismo e defensores do amadorismo (APEA versus LAF), e amargurado com duas derrotas consecutivas contra o time da capital.

\subsubsection{A chave para a vitória}

Os paulistas, que de início imaginaram ter alcançado uma hegemonia nacional imbatível, exigiam uma recuperação após duas derrotas consecutivas. Logo no início do ano de 1926, os jornalistas d'A Gazeta começam a se manifestar, Salathiel de Campos entre eles. Como já dissemos, a argumentação gira em torno do desempenho esportivo, deixando apenas implícita a questão racial - que só seria categoricamente afirmada nos anos 30. De qualquer forma, em abril daquele ano começa a campanha, assim que fora anunciada a taça Washington Luiz, a ser disputada contra o selecionado do Paraná - uma espécie de pré-temporada dos anos 20, com o perdão pelo anacronismo da analogia.

\footnotetext{
${ }^{88}$ Correio Pauistano, Caderno de Esportes, O homem negro no esporte bandeirante, 07/10/1934. Pag.11, rodapé.
} 
No selecionado que, supunham os jornalistas, seria convocado para esta taça, não havia nenhuma negro ${ }^{89}$. Talvez por essa razão, em 17 de abril a coluna Écos d'A Gazeta repercute uma ideia, publicada antes pelo jornal Paiz do Rio de Janeiro: a APEA deveria organizar duas seleções e realizar um jogo entre elas na capital do país. "Quem não quer assistir à uma formidavel lucta entre dois fortes seleccionados da Paulicéa, cujos jogadores são muito apreciados aqui?"90 dizem os cariocas. No elenco do segundo time, como sugerido pelo jornal, consta o nome de Petronilho de Brito, o Petro, uma figura importante, que aparecerá mais tarde no livro de Salathiel de Campos como uma das maiores referências na história do negro no esporte de São Paulo. O apoio a essa ideia parece ter sido uma forma - ainda que incipiente - de começar a incluir jogadores negros nos trabalhos do selecionado paulista.

Na mesma página, recebe destaque o atleta Melinho, "um dos melhores elementos" do Velo Clube de Rio Claro. De uma lado, a necessidade de mudanças, a proposta de uma espécie de selecionado reserva onde poderiam entrar atletas que não costumam ser convocados; de outro, o destaque a um craque negro do interior - alguém que poderia muito bem ser convocado se a ideia fosse executada.

No dia de Tiradentes, 21 de abril, é publicada a coluna A APEA e a formação dos seus seleccionados - os jogadores do interior não podem ser esquecidos, uma das mais contundentes:

"Dentro em breve a Commissão de Futebol da Apea organizará as turmas que deverão jogar os interestaduais e tomar parte no Campeonato Brasileiro. Não sabemos qual o critério que presidirá á escolha ados elementos que constituirão o nosso onze máximo.

Qualquer que seja porém, a deliberação a tomar nesse sentido é preciso que não se esqueçam de chamar para os treinos preparatórios certos elementos da Divisão do Interior, que se revelaram capazes de contribuir brilhantemente para a efficiencia do nosso quadro representativo.

Quem quer que tenha assistido aos jogos finaes do Campeonato do Interior que se realizaram nesta Capital, deve ter observado a actuação, impeccavel mesmo, de alguns jogadores que podem perfeitamente rivalizar com os laureados da Primeira Divisão.

\footnotetext{
${ }^{89}$ A Gazeta, 07/04/1926. Disponível em <http://bndigital.bn.gov.br/hemeroteca-digital/>

${ }^{90}$ A Gazeta, 17/04/1926, pag 6, 1a coluna. Disponível em <http://bndigital.bn.gov.br/hemerotecadigital/>
} 


\section{(...)}

O momento actual não comporta essa politica circumscripta aos que estão de perto. É preciso vistas largas. É necessário considerar que, no ajuste de contas todos pesam na balança.

A organização de diversas divisões não representa differença de direitos e qualidades. Pensar ao contrario é cooperar lamentavelmente para a derrocada do patrimonio esportivo que fez em tempos idos a gloria e a supremacia do futebol, na terra dos bandeirantes.

Queremos crer que desta vez a Comissão de Futebol aproveitará as licções do passado e organizará o nosso seleccionado, chamando os que de facto estão na altura de participar desses jogos de tanta responsabilidade esportiva, sejam eles desta ou daquela divisão e isso fazendo animados de espirito de justiça e equidade."

A coluna é ilustrada com fotos de dois desses craques que poderiam "contribuir brilhantemente para a efficiencia do nosso quadro representativo", Mellinho e Augusto Americo:

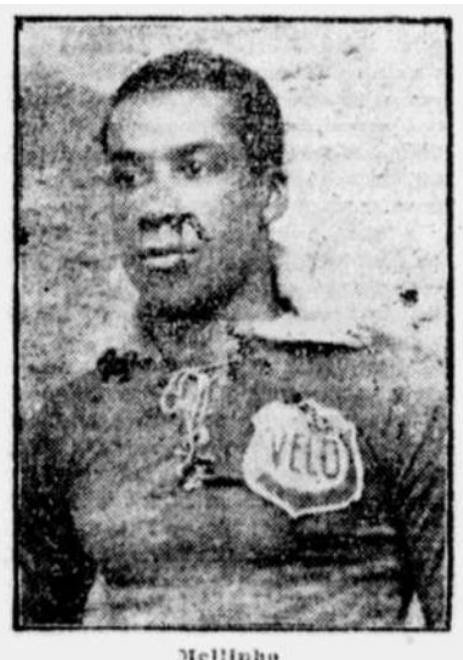

Mellinho

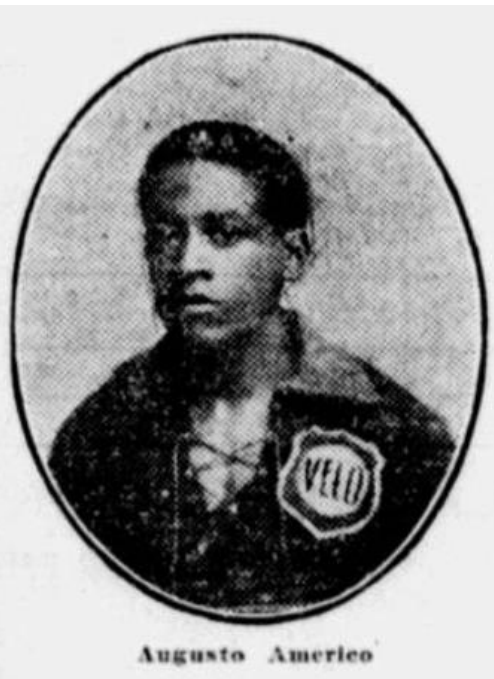

Imagem 3 - Mellinho e Augusto Americo, jogadores do Velo Clube de Rio Claro, estampados no Caderno de Esportes d'A Gazeta em 21/04/1926.

O que acabamos de ver demonstra a forma básica de como se desenrolou a militância nas páginas do jornal ao longo daquele ano:

1- O desafio: o campeonato interestadual, certame no qual o selecionado paulista vinha de duas derrotas.

\footnotetext{
${ }^{91}$ A Gazeta, 21/04/1926, pag 6, 1a coluna. A APEA e a formação dos seus seleccionados - os jogadores do interior não podem ser esquecidos. Disponível em <http://bndigital.bn.gov.br/hemeroteca-digital/>
} 
2- O problema: a falta de clareza a respeito dos critérios de convocação e a política "circumscripta aos que estão de perto"

3- A solução: não deixar de fora certos elementos valorosos, porque diferentes divisões não significam diferentes direitos e qualidades e há atletas, normalmente ignorados, que podem colaborar com a eficiência do selecionado.

O caminho argumentativo desse grupo de jornalistas militantes mostra que a justiça e a equidade andavam juntas com uma potencial melhora do desempenho esportivo. Mostram maior preocupação com o resultado do campeonato do que com a superação do preconceito de cor, mas, ao mesmo tempo, como sugestão de convocação colocam dois jogadores negros, normalmente esquecidos pelos dirigentes da época, tão criticados pelos jornalistas d'A Gazeta.

Nessas colunas, procuravam criticar a APEA de todas as formas, especialmente a falta de treinos do selecionado paulista em comparação com os cariocas, atribuída a uma má gestão dos diretores, os chamados "maiores":

\section{“(...) Mas, que adeantarão medidas de ultima hora si o principal nos falta, que é o tempo para treinar conjunto dos mais heterogêneos? (...) É que, infelizmente, entre nós os 'maioraes' pensam que organizar seleccionado depende unica e exclusivamente de discussões e acordos na secretaria e, depois, rotular de seleccionado um onze de jogadores mais ou menos em evidencia. E só!}

Outr'ora, quando nossos campeões actuavam seguidamente em conjunto, isso era tolerável, cabível mesmo. Mas, agora que há necessidade de verdadeira reconstrução não se compreende tal politica. "92

O primeiro trecho expõe a falta de planejamento, ao falar de "medidas de última hora". Como agravante, esse selecionado "heterogêneo" precisa de tempo para treinar, o que não há. Segundo o texto, se faz necessária uma "reconstrução". Isso é importante de duas formas: primeiro, porque apontam novamente o dedo para os diretores, não vemos aqui qualquer crítica aos atletas; segundo, porque ao propor tal reconstrução, os jornalistas defendem, como já vimos, a convocação de atletas das divisões inferiores e

\footnotetext{
${ }^{92}$ A Gazeta, 25/06/1926, pag 6, 1a coluna. Campeonato brasileiro - a pouca vontade apeana. Disponível em <http://bndigital.bn.gov.br/hemeroteca-digital/>
} 
dos times do interior - espaços do campo esportivo que já começavam a ser ocupados por atletas negros.

Continuam a crítica à classe dirigente ao dizer que as escalações e convocações são feitas por um "conselho director", com pouca interferência da Comissão de Futebol:

"Ora, isso francamente, não está direito. O que a Apea deve fazer é escolher uma comissão de dois ou tres technicos competentes e dar-lhes amplos poderes para escalar e, sobretudo, treinar a turma. Esse negocio de põe este jogador, porque é do clube tal ou aquelle outro, porque deve jogar bem com fulano dos onzões carapucas, e cousas que taes, não adeantam. Isso somente denota má orientação, ponto de vista errado, erradissimo mesmo.

O exemplo carioca é frisante. Depois que a Chico Netto, e a mais dois ou tres competentes, foi entregue a direcção do seleccionado da capital da Republica, toda gente viu o que sucedeu. Um sucesso! Em dois annos seguidos, nossos velhos rivaes da Guanabara venceram brilhantemente o máximo concurso nacional. $O$ exemplo, pois, deve ser imitado." 93

O problema era a falta de clareza a respeito dos critérios de convocação, sua causa: a convocação era feita pelos paredros, não por gente do campo e bola. Se fosse o caso, parecem acreditar os jornalistas, a convocação seria mais justa, os treinos seriam mais produtivos e o desempenho dos cariocas, tidos como exemplo, seria alcançado. Os critérios dos dirigentes "não adeantam", como foi dito, e por ai é que os jornalistas constroem sua argumentação. A atual configuração deixou de ser vitoriosa, por dois anos seguidos "nossos velhos rivaes da Guanabara venceram brilhantemente o máximo concurso nacional", portanto, é necessária a reconstrução total, que passa por uma escolha técnica dos atletas, além de treinos melhores e mais frequentes.

Depreendemos desse texto que, com a atribuição dessas funções a uma comissão técnica, aos atletas negros bastaria demonstrar qualidade técnica suficiente para que fossem convocados. Se lembrarmos do argumento de Salathiel de Campos em seu texto sobre o Bloco dos Caboclos, de que ao homem negro basta um treino moral e físico para

\footnotetext{
${ }^{93}$ A Gazeta, 06/07/1926, pag 6, 1a coluna. Nosso seleccionado e seus technicos. Disponível em $<$ http://bndigital.bn.gov.br/hemeroteca-digital/>
} 
alcançar seu potencial inato de atleta, a proposta do jornal se apresenta não só como uma opinião técnica mas também como uma forma de militância por equidade de condições a brancos e negros.

A Gazeta fazia seu jogo no campo esportivo da época, e nos parece que o posicionamento do jornal surtia efeito. Vejamos o exemplo de Mellinho e Augusto Américo, jogadores do Velo Clube. Na coluna de 21 de abril que analisamos anteriormente a convocação desses atletas foi defendida e suas fotos estamparam o caderno de esportes. No dia 7 de junho, a coluna Écos informa que conversou com um dos "mentores apeanos" e anuncia os possíveis quadros que iriam treinar "dentro em breve". No time B, consta a convocação dos craques negros do Velo de Rio Claro ${ }^{94}$.

Numa outra publicação, acionando rivalidades locais, o jornal cita os treinos dos cariocas e da LAF - a liga de elite liderada pelo Paulistano que e lutava contra a profissionalização - para expor a falta de treinos da APEA:

"Os cariocas deram hontem seu segundo treino collectivo.

Quanto aos demais concorrentes, é cousa sabida que de há muito se preparam.

E os paulistas!?

Nada.

(...)

Os lafeanos treinam seu seleccionado: - si os apeanos fizessem o mesmo!"95

Cinco dias depois, os treinos começam. E os cronistas mostram que a mesma pena que critica, também elogia:

"Segundo nos asseverou um membro da Comissão de Futebol da Apea, já foram iniciados os treinos individuaes de nossos campeões para o próximo campeonato nacional de futebol. Muito bem! "96

\footnotetext{
${ }^{94}$ A Gazeta, 07/06/1926, pag 6, 1a coluna. Nossa turma. Disponível em $<$ http://bndigital.bn.gov.br/hemeroteca-digital/>

${ }^{95}$ A Gazeta, 05/08/1926, pag 6, 1a coluna. Campeonato brasileiro - a pouca vontade apeana. Disponível em <http://bndigital.bn.gov.br/hemeroteca-digital/>

${ }^{96}$ A Gazeta, 10/08/1926, pag 6, 1a coluna. Campeonato brasileiro - a pouca vontade apeana. Disponível em <http://bndigital.bn.gov.br/hemeroteca-digital/>
} 
Por esses e outros exemplos que ainda serão demonstrados, vemos que não é absurda a leitura que acabamos de propor. As páginas d'A Gazeta de fato tinham importância no campo esportivo, ao menos naquele momento. No nosso recorte temporal, os jornalistas d'A Gazeta aparecem como agentes desse campo, parte de uma imprensa esportiva que então se formava. Com sua agência, defendem valores de equidade e justiça para constituir uma representação baseada no mérito e cujo objetivo é a excelência. Assim, entendem que haverá espaço para todos, especialmente para os negros até então alijados, uma vez que - pelo menos na opinião já anunciada de Salathiel de Campos teriam um talento inato para a prática esportiva.

No início de junho, a coluna Écos traz mais um texto sobre o selecionado paulista, no qual transcrevem uma conversa que ouviram. O papo, ouvido com "um pouco de indiscreção", versava sobre a convocação do selecionado paulista. Diziam que foi feita uma votação entre dez dirigentes para chegar aos nomes finais. Na suposta lista final, consta Petronilho de Brito, o que seria uma vitória para os militantes do jornal. Algumas convocações, como a de Moura, são atribuídas à “Política, meu caro...”. Mas, e “quanto aos rapazes do Velo que falaram por ahi?....Nada!"97. A vitória, então, era apenas parcial.

De forma inteligente, nas edições seguintes são apresentadas escalações enviadas pelos leitores. Não foi possível saber quantas e quais convocações chegaram à redação, mas é interessante notar que, entre as publicadas, sempre constava algum atleta negro. Uma possível forma de mostrar que havia apoio popular à ideia que defendiam.

Outra forma de mostrar que não estavam sozinhos nessa militância foi a publicação de uma conversa com Pedro Belhot, o "estimado esportista uruguayo", correspondente do Imparcial, de Montevideo. Belhot comenta a evolução dos quadros cariocas e diz que convocaria Petronilho ao selecionado paulista ${ }^{98}$. Importante lembrar que, à época, a opinião de um uruguaio em questões futebolísticas era especialmente importante. O selecionado do Uruguai havia disputado, até então, sete finais em dez edições do Campeonato Sul-Americano, conquistando seis títulos (o de 1926 incluso). Além disso, eram os atuais campeões olímpicos, tendo conquistado o ouro em 1924 na cidade de Paris. Os uruguaios eram, certamente, a maior referência do futebol na América

\footnotetext{
${ }^{97}$ A Gazeta, 09/06/1926, pag 6, 1a coluna. Nossa turma - um pouco de indiscreção. Disponível em <http://bndigital.bn.gov.br/hemeroteca-digital/>. Acesso em 13/04/2015.

98 Idem.
} 
do Sul. Jonathan Wilson, em Pirâmide Invertida ${ }^{99}$, chega a afirmar que o Uruguai praticava o futebol arte sul-americano, uma forma-representação que mais tarde seria construída em torno da "escola brasileira"

Até um jogo de homenagem a Formiga, organizado pela LAF, no qual um combinado de jogadores enfrentaria o Paulistano - clube que liderava a liga dos amadores - virou pretexto para falar de raça no esporte: "Como se vê, no seleccionado figura um elemento do interior. É Nabor, o excelente ponteiro do Carioca de Villa Americana”. ${ }^{101}$ À primeira vista, estas e outras publicações parecem apenas parte da pauta do caderno de esportes, nada além do normal. Mas, em uma análise mais cuidadosa, percebemos que todas oportunidades de se tocar no assunto são aproveitadas, as vezes até criadas propositalmente. Em praticamente todas as edições do jornal há alguma referência a bons jogadores do interior, das divisões inferiores, e alguma crítica à gestão da APEA, seja sobre a forma de realizar as convocações, seja sobre a falta de treinamentos.

Como já ficou claro, os cariocas eram sempre citados como uma referência. Seja como uma provocação à APEA, apelando para a rivalidade local, ou porque conquistaram os dois últimos campeonatos interestaduais. Então, no dia 18 de agosto é publicada uma longa matéria, que ocupa quase toda metade superior do caderno de esportes: $O$ veterano campeão carioca Epaminondas Berlitz fala á “Gazeta”.

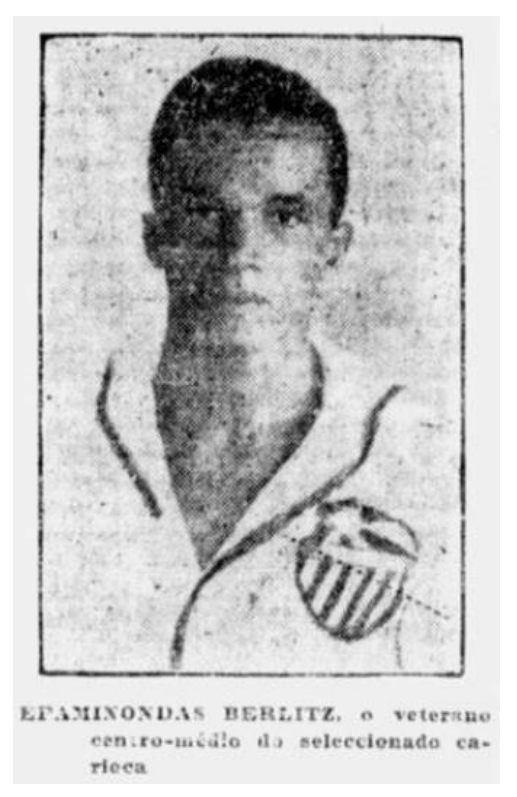

\footnotetext{
${ }^{99}$ WILSON, Jonathan. A Pirâmide Invertida: a história da tática no futebol. São Paulo: Grande Área. 2016. 100 Falaremos mais sobre o conceito de forma-representação e sobre as ideias de futebol arte nos próximos dois capítulos.

${ }^{101}$ A Gazeta, 10/07/1926, pag 6, 1a coluna. Disponível em <http://bndigital.bn.gov.br/hemerotecadigital/> Acesso em 13/04/2015.
} 
Imagem 4 - "Epaminondas Berlitz, o veterano centro-médio do seleccionado carioca"102

A entrevista de Epaminondas Berlitz, um jogador negro que atuou no São Cristóvão e na seleção estadual carioca, corre quase como uma conversa. Falam, primeiro, do início de carreira, da estreia na divisão principal. Depois, o jogador conta a história de como atuou em uma partida internacional antes de ter jogado qualquer interestadual, e então essa competição toma o centro do assunto:

\section{“ - Actuou muitas vezes em interestaduaes?}

- Innumeras! Já joguei contra paulistas, mineiros e fluminenses.

\section{- Qual foi o jogo de maior contagem?}

- Foi contra os mineiros, a segunda vez que nos visitaram.

Vencemos por $15 \times 0$, batendo o recorde nacional de pontos, em jogos interestaduaes. Nesta Capital joguei tres vezes: dois jogos officiaes e um treino." 103

Eis ai o exemplo que, na visão destes jornalistas, davam os cariocas aos paulistas. Um atleta negro já jogava na seleção carioca a ponto de estar quase aposentado. Quando perguntado se continuará no futebol, responde: "Nada tenho resolvido. Embora me ache um pouco velho e cançado, é possivel que ás vezes apareça..." ${ }^{104}$. Sendo, então, além de um exemplo bem sucedido de atleta negro, um esportista experiente, sua opinião sobre São Paulo é perguntada. A isso se segue a melhor parte da entrevista, que também a encerra (estão grifadas as intervenções do repórter):

“- S. Paulo parece que se debate em tremenda crise, e dorme a sombra dos louros do passado.

- Triste marasmo de quem sempre foi campeão...

- O povo desinteressou-se em parte e desertou dos campos de futebol.

- É verdade. A nossa decadencia é manifesta...

- Eu julgo que S. Paulo este anno, talvez se reabilite. A decadencia dos paulistas é apenas moral, e assim sendo, e si se tiver em conta o valor dos elementos, as cousas mudarão de figura...

\section{- Julga isso?}

\footnotetext{
${ }^{102}$ A Gazeta, 18/08/1926, pag 6, 1a coluna. Disponível em <http://bndigital.bn.gov.br/hemerotecadigital/>

103 Idem.

104 Idem, ibidem.
} 
- Perfeitamente. Assisti aos treinos dos apeanos e, francamente, acho o quadro excellente, principalmente na defesa. Quanto á linha julgo necessária uma reforma. Bisoca é um elemento indispensável na extrema direita e, portanto, a sua inclusão deve ser fora de duvida.

\section{- Bisoca tem se revelado.}

- Si entregarem a direcção a Amilcar, ou ouvirem as suas opiniões sensatas de techinico consumado, é pois certa a reabilitação.

- De modo que o quadro seria este: Tuffy, Grané, Bianco, Xingo, Amilcar, Serafim, Bisoca, Neco, Feitiço, Araken e Mello.

- Isso mesmo. Depois é só questão de treinos.

\section{- Quaes os melhores elementos apeanos?}

- Em primeiro lugar, Amilcar. O grande centro-médio patrielo está ainda melhor do que fôra. Não decae. É um excellente jogador e technico profundo. Depois Neco, Grané, Bianco, Bisoca, Giby, Tuffy e outros.

\section{- Que acha da actual situação esportiva?}

- Ainda é cedo para se dar opiniões. Emtanto, direi que technicamente a LAF nada apresentou de novo. Ao contrario, os seus jogos são fraquissimos. Póde ser que mais tarde melhorem. Quanto á parte social, não ha duvida. O seu progresso é manifesto: outra torcida, outro publico. Muita cordialidade...

Emfim, são cousas para o futuro.

Por muito tempo ainda conversamos sobre interessantes cousas esportivas e o estimado esportista não escondia a sua admiração e enthusiamos por Amilcar.

Com um forte abraço despediu-se e lá se foi escadas abaixo o antigo e apreciado centro-médio do seleccionado carioca. "105

Com as fontes disponíveis, é impossível cotejar o que foi dito com o que foi escrito. Não acreditamos que haja uma gravação da entrevista, em áudio, única fonte que nos permitiria confirmar cada resposta. Ficamos apenas como que está impresso, com o que podemos ver uma clara semelhança entre o discurso do entrevistado e dos entrevistadores.

\footnotetext{
105 Idem, ibidem.
} 
O atleta corrobora com a ideia de decadência do futebol paulista - no que os jornalistas se baseiam para propor uma reformulação do selecionado. Cita Bisoca - um dos atletas negros cuja convocação era defendida pelo jornal - como "um elemento indispensável” e defende que "sua inclusão deve ser fora de duvida". Diz que São Paulo voltará a ter sucesso "se tiver em conta o valor dos elementos", exatamente o argumento de mérito utilizado pelos jornalistas como já vimos antes. Diz ainda que deveriam "entregar a direcção a Almicar" para atuar, além de jogador, como técnico (algo comum neste período), opinião compartilhada pelos cronistas. Quase que repetindo as palavras de Salathiel de Campos, diz que após isso tudo "é só questão de treinos". Por fim, alinhado com Salathiel de Campos no que diz respeito à importância dada a supostos valores morais e à admiração do convívio social da elite que praticava o futebol amador, Epaminondas diz quanto à "parte social" da LAF "não ha duvida. O seu progresso é manifesto: outra torcida, outro publico".

Não podemos afirmar que houve grande distorção das palavras do atleta, nem tampouco que ele era, de fato, um grande apoiador da causa dos jornalistas. Mas, de uma forma ou de outra, a publicação é importante pelo que apresenta, ou pelo que escolheram apresentar. Este é o discurso: vemos um atleta negro vitorioso, que já jogava na seleção carioca bicampeã há algum tempo, e que em seu discurso reforça as principais opiniões emitidas pelo caderno de esportes d'A Gazeta nos últimos meses.

A estratégia do jornal foi bem sucedida.

\subsubsection{A vitória}

\section{"Campeonato Brasileiro de Futebol}

Realiza-se hoje o ultimo treino de nossos campeões para a organização de nossa turma que domingo proximo enfrentará os catharinenes, em disputa do campeonato brasileiro. Até agora não se sabe, ao certo, como ficará constituída a representação paulista. $O$ "Xis" está na zaga e na extrema direita. Todaviaaffirmou-nos alto paredro apeano - é quasi certo que treine hoje o seguinte 'onze':

Tuffy

Grané-Gibi

Xingo-Amílcar-Serafim

Bisoca - Heitor - Petro - Feitiço-Mello" 
Aparentemente, a campanha conseguiu importantes avanços. Estão presentes no selecionado: Gibi, Bisoca e Petro. Os três atletas negros da capital, que jogavam pelo Syrio. Já era um avanço, apesar de Mellinho, do Velo de Rio Claro, ter ficado de fora e seu companheiro, Augusto Américo, apenas para um possível time B.

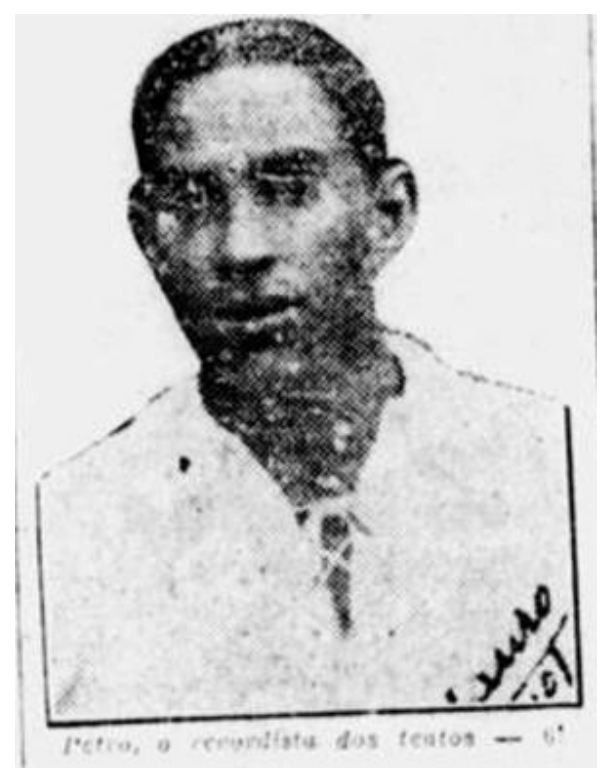

Imagem 5 - Petronilho de Brito, convocado após a mobilização dos jornalistas n’A Gazeta, seria um dos destaques do Campeonato Interestadual. ${ }^{106}$

No final de outubro, na reta final do Campeonato Interestadual de 1926, o sucesso destes jogadores já era evidente. Especialmente de Petro. O selecionado paulista acumulava placares elásticos, mesmo para essa época do esporte, caracterizada pelos muitos gols. Contra Santa Catarina, placar de 16 a 0 - seis gols de Petronilho. De 5 a 3 contra o Rio Grande do Sul - um gol de Petronilho. E de 13 a 1 contra a Bahia - cinco gols dele. No dia 30, o jornal mostra o quadro dos artilheiros. Petro era líder, com doze gols, cinco a mais que o vice artilheiro, Ladislão, que tinha sete. ${ }^{107}$

Não foi surpresa quando, no dia 7 de novembro, no estádio das Laranjeiras, o selecionado paulista voltou a ser campeão interestadual. Como em todas edições anteriores, a final foi contra os cariocas. Dessa vez a vitória veio com gols de Petronilho, o grande craque daquela competição, símbolo da campanha realizada no jornal A Gazeta.

Não faltaram empecilhos a essa campanha. Os jornalistas engajados recebiam cartas "indelicadas e disparatadas", telefonemas "insolentes que esteriotyparam a triste

\footnotetext{
${ }^{106}$ A Gazeta, 27/09/1926, pag 6, 1ạ coluna. Disponível em <http://bndigital.bn.gov.br/hemerotecadigital/>

${ }^{107}$ A Gazeta, 30/10/1926, pag 6. Disponível em <http://bndigital.bn.gov.br/hemeroteca-digital/>
} 
mentalidade de seus autores", e com isso alguns dos militantes "se quedaram silenciosos", alguns esportistas (brancos) agiram silenciosamente para que "os negros não viessem a quebrar a harmonia"108 do futebol. Essas cartas, por enquanto, não foram encontradas, mas certamente revelariam novas possibilidades de pesquisa. Falamos de cartas como algo do passado, fonte para historiadores, mas infelizmente não podemos deixar de comentar a atualidade vergonhosa dessas manifestações racistas. Como os leitores que enviaram estas missivas em 1926, o fazem muitas pessoas de nosso tempo em comentários de internet, nos portais de notícias e redes sociais.

Salathiel revela que a campanha não foi bem vista pelos "mentores apeanos"109, como era de se imaginar pelo que vimos até aqui. Mas, enfim, vencidas (ou ignoradas) as barreiras, Petro teve sua lugar garantido, Giby só não foi convocado porque adoecera, e Bisoca também foi incluído. Não sem alguma polêmica.

O jogador havia sido "victima da brutalidade despeitada de um adversário"110 em um treino, com os joelhos machucados, mal podia andar. Segundo o jornalista, para "demolir o prestígio" do jornal que os incomodava, os dirigentes da APEA escalaram Bisoca, mesmo machucado, e o levaram para o jogo no Rio de Janeiro. Leopoldo Sant'Anna, assim como o próprio jogador, inutilmente tentaram tirá-lo do jogo, mas ele jogou e não pode "desenvolver toda a sua brilhante actuação que o consagrara o melhor extrema direita de S. Paulo e quiçá do Brasil"111. Apesar dessa tentativa de sabotagem, Bisoca acabou sendo importante para a vitória do selecionado paulista nesse jogo. Com uma assistência dele, após bela jogada, Petro fez o gol da vitória.

“A resistência passiva se prolongara por muito tempo, mas vencemos afinal. ",112

Ao voltar suas críticas aos dirigentes, ao deixar claro que as escolhas não são técnicas, mas guiadas por uma questão racial, estes jornalistas, Salathiel de Campos entre eles, expuseram o racismo pela agência do racista, e não por pela suposta passividade do negro que sofre racismo. Estes, os atletas, eram enumerados entre tantos outros, brancos brasileiros, brancos imigrantes, brancos ricos ou pobres, portanto desvinculados da cor

\footnotetext{
${ }^{108}$ Correio Pauistano, Caderno de Esportes, 16-10-1934. Pag.8

109 Idem.

110 Idem, ibidem.

111 Idem, ibidem.

112 Idem, ibidem.
} 
de sua pele, tratados apenas como bons atletas que eram. Já os dirigentes, estes eram expostos como conscientemente racistas, conhecedores das habilidades dos jogadores negros, mas que para eles fechavam as portas.

Essa foi uma manifestação antirracista organizada e sistemática feita no primeiro ano do governo de Washington Luís, a quem seria atribuída a frase: "A questão social é um caso de polícia". O mesmo que, no ano seguinte, em 1927, aprovou a lei celerada, que ampliava a regulação da mídia e cerceava o direito de reunião. Dentro dos parâmetros, linguagem, dinâmica e organização do campo esportivo da época, este é um importante exemplo de militância em favor da população negra no esporte. Limitada pelo tabu do tema racial, mas que jogou conforme as regras do jogo daquele momento habilidosamente.

Salathiel de Campos, então com 25 anos, certamente aprendeu muita coisa nesses últimos anos, especialmente em 1926. Formou opinião, se posicionou no campo esportivo e, como veremos a seguir, logo se posicionaria no campo político de seu tempo. Nos anos seguintes, o jornalista foi membro fundador de dois importantes movimentos sociais da São Paulo dos anos 20 e 30: o patrianovismo, movimento monarquista, e a Frente Negra Brasileira, um dos grupos mais importantes da história do movimento negro no Brasil.

\subsection{A militância fora do papel (1926-1937)}

"O que distingue o homem não é elle proprio, mas sim a sua mentalidade." 113

Salathiel de Campos.

Mesmo não querendo transformar o objeto desta pesquisa, Salathiel de Campos, em algo único, mítico, o que seria um erro, não podemos deixar de apontar a gritante predominância de homens brancos no campo esportivo daquele momento. Se para que os negros jogassem futebol foram necessárias mobilização e luta, a presença de pessoas negras nas redações e na sede social dos clubes de futebol eram ainda mais raras. Salathiel de Campos conviveria entre brancos nos dois espaços. Como veremos mais adiante, há alguns outros jornalistas negros com trajetórias parecida, como Lino Guedes e Gervásio de Moraes.

113 idem 
Exceções que compravam a regra. A população negra estava condenada, em sua maioria, ao analfabetismo, aos empregos informais, braçais e desgastantes ${ }^{114}$. Isso se falarmos da população negra urbana, uma vez que a maior parte dessa população ainda vivia no campo, onde não eram encontradas condições muito melhores.

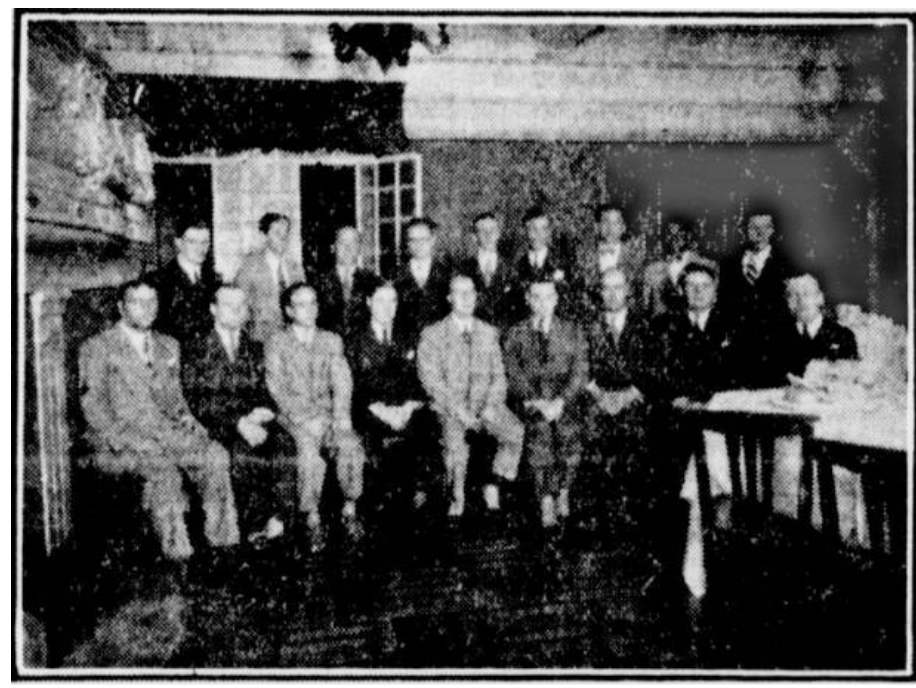

Imagem 6 - Salathiel entre colegas de trabalho e dirigentes de clubes esportivos, segundo homem da direita para a

Salathiel de Campos tinha, portanto, uma posição privilegiada na modernidade negra $^{115}$ paulistana, e aproveitou as aberturas que teve para atuar de forma importante tanto no campo esportivo quanto no político, um dos agentes que contribuíram com um movimento negro em ascensão e que lideraram conquistas em espaços específicos.

Durante a mobilização que acabamos de apresentar, quando Salathiel de Campos militou com outros colegas por meio das páginas d'A Gazeta, ele ainda não fazia parte de nenhum movimento social organizado. Mas isso aconteceria rapidamente.

Foi membro fundador da Associação Paulista de Imprensa (1933), da Associação dos Cronistas Esportivos (1933), fundou como sócio e dirigiu a Empresa Jornalística de Informações Gerais (EJIG), e participou também da Federação de Ciclismo e Motociclismo "conquistando para essas modalidades de esportes o prestígio que hoje elas gozam em todo o território brasileiro". ${ }^{116}$

Muito ativo na organização e mobilização dos esportes como um todo, atuando até, como vimos, como árbitro de linha em competições de atletismo, e também da sua

\footnotetext{
${ }^{114}$ ROSENFELD, Anatol. Negro, macumba, futebol. São Paulo: Perspectiva, 1993.

115 GUIMARÃES, 2003 in: FERREIRA, Maria Cláudia. Espaços de sociabilidade e ações anti-racismo no cotidiano das elites negras na cidade de São Paulo: busca por projeção individual e legitimidade de grupo (1900-1940). Revista Mosaico, no 3, ano II, 2010. Pag.2

${ }^{116}$ SÃO PAULO, Diário Oficial, Requerimento no 1074.52, 15 de setembro de 1952. pag.52-53
} 
categoria profissional, Salathiel de Campos também marcava presença na imprensa negra, nas congregações maristas e em bailes e festas organizados pela e para a população negra, espaços de sociabilidade possíveis para uma população que fora excluída quase completamente dos chamados "territórios brancos"117. Fez parte também o Centro Cívico Palmares, fundado em 1926 por Arlindo Veiga dos Santos com ajuda de Lino Guedes e Gervásio de Moraes, citados anteriormente. Estas podem ter sido as portas de entrada de Salathiel de Campos para os movimentos sociais organizados.

Essa participação, com a distância do tempo, parece até natural, uma vez que Salathiel era, antes de tudo, alfabetizado - ainda hoje o analfabetismo é um problema no Brasil e afeta, desproporcionalmente, a população negra. Além disso, havia trabalhado em cartório ${ }^{118}$, em jornais importantes como o Correio Paulistano e A Gazeta, publicado um livro, tinha experimentado as primeiras manifestações públicas como um militante da causa negra. Por isso tudo, podemos afirmar sem receio que o jornalista não foi uma FNB Negra Brasileira. Ele foi, na verdade, um intelectual, já politizado, que participou de diversos movimentos como membro fundador.

O espaço onde ele teve reconhecimento mais precoce, no entanto, não foi a política. Foi no futebol de várzea, que cobria como jornalista já há alguns anos. Em junho de 1928, como noticiou a Folha da Manhã , foi organizado um torneio com vinte clubes de várzea, e a primeira das dez taças que seriam disputadas recebia seu nome. Além da "Taça Salathiel de Campos", seriam disputadas outras como a "Julio de Mesquita", "Leopoldo Sant'Anna" e "Alvaro de Campos"119.

Saído do futebol de varzea como alguns dos craques do futebol de sua época, o já homenageado Thylba estava prestes a ingressar de vez na atuação política.

\subsubsection{Ação Imperial Patrianovista}

Este movimento foi fundado no dia 3 de março de 1928 por Arlindo Veiga dos Santos e seu irmão Isaltino Veiga dos Santos. O primeiro, era o principal líder do grupo e, aparentemente, um mentor para Salathiel de Campos. A Ação Imperial Patrianovista na verdade é uma extensão do Centro Monarquista de Cultura Social e Política Pátria Nova, criado pelos irmãos Veiga em parceria com um grupo de jovens católicos.

\footnotetext{
${ }^{117}$ Idem. Pag.6

118 SÃO PAULO, Diário Oficial, 14 de junho de 1949. pag.3

${ }^{119}$ FOLHA DA MANHÃ, ESPORTES, 06/06/1928, pag 9, 1acoluna.
} 
Retomando os espaços que podem ter permitido os primeiros contatos de Salathiel com os movimentos sociais, citamos Teresa Malatian, que fala a respeito dos fundadores deste movimento:

“(...)Os demais fundadores da Pátria-Nova haviam sido recrutados na cidade de São Paulo, nas congregações marianas, na Faculdade de Filosofia e Letras e na Faculdade de Direito: Paulo Dutra da Silva (engenheiro), seu irmão Joaquim Dutra da Silva (advogado e bacharel em Filosofia e Letras), Paulo Sawaya (estudante de Medicina), Aguinaldo G. Ramos (bacharel em Filosofia e Letras), Carlos Prado (médico), Salathiel Campos (jornalista, redator do Correio Paulistano)..."

É possível supor que o jornalista tenha sido um dos recrutados em congregações marianas, organizações de leigos católicos, uma vez era alguém muito religioso - como vemos no seguinte trecho a respeito de Salathiel de Campos publicado no Diário Oficial na ocasião de sua homenagem póstuma, em 1952:

"releva salientar a magnanimidade de sua alma, a pureza de seu coração e o dom do perdão, que bebera nos ensinamentos da Doutrina Cristã, religião que sempre professou esse baluarte das letras jornalísticas ",121

Outra razão para acreditar que este foi o espaço onde teve contato com o movimento de fundação da Ação Patrianonista é o fato de que não fazia parte nem da Faculdade de Letras, nem da Faculdade de Direito. O diploma de bacharel que conseguiu, apenas anos mais tarde, foi em Ciências e Letras pelo Ginásio Oswaldo Cruz, tendo sido inclusive negada a sua entrada como aluno do Largo do São Francisco. ${ }^{122}$

De qualquer forma, não é provável que tenha havido apenas um espaço de contato. Essa classe média negra não era tão numerosa, e convivia em espaços específicos. Já falamos do Centro Cívico Palmares, dos bailes e festas, é uma possibilidade que Salathiel de Campos tenha encontrado com Arlindo Veiga dos Santos em algum desses espaços.

Dada a afinidade destes agentes, suas alianças e empreitadas políticas em comum, podemos supor aproximações ideológicas entre os dois ou, no mínimo, conhecer melhor

\footnotetext{
120 MALATIAN, Teresa. O tradicionalismo monarquista (1928-1945). Revista Brasileira de História das Religiões. ANPUH, Ano VI, n. 16, Maio 2013. Pag. 79

121 Idem.

122 SÃO PAULO, Diário Oficial, Requerimento no 1074.52, 15 de setembro de 1952. pag.52-53
} 
os agentes com os quais Salathiel de Campos se relacionava. Para tanto, os estudos de Petrônio Domingues (2006), Teresa Malatian (2013) e Regina Pahim Pinto (2013), nos ajudam a compreender o aparato ideológico de Arlindo Veiga, líder em comum da Ação Patrianovista e da Frente Negra Brasileira.

Identificamos que a "raça brasileira" propalada por Veiga dos Santos era especialmente negra e mestiça, uma versão da raça de índio-português-negro (descrita por Gilberto Freyre) que valorizava a negritude acima de tudo. Em oposição à "raça brasileira”, está o estrangeiro. O discurso deste líder negro era carregado por uma hostilidade aos imigrantes, os "oportunistas" ou "alienígenas". Em O Homem Negro no Esporte Bandeirante, Salathiel de Campos aproveita as ideias de "raça brasileira" e resistência ao estrangeiro como veremos mais adiante. As apresenta como uma defesa da nação e, também podemos supor, da população negra, que havia perdido espaço - ou nem sequer conquistado - com o avanço da imigração - especialmente italiana, no caso paulista.

Encontrando essas proximidades ideológicas, podemos entender melhor quem era Salathiel de Campos a partir da agenda de Arlindo Veiga dos Santos. Para continuar esta análise, apresentamos o programa patrianovista, publicado na revista do movimento em 1929, quando já contavam com a participação de Salathiel:

"I - CREDO - Privilégio do Catolicismo, Religião obrigatória nas escolas públicas, nos quartéis, institutos hospitalares e correcionais, etc.

II - MONARQUIA - Imperador responsável que reine e governe, escolhendo livremente os seus ministros. Base municipal sindicalista da organização do Estado Imperial. Direitos magestáticos da Dinastia Nacional, aclamada pela Nação no fundador político da Pátria Imperial Brasileira D. Pedro I, e agora representada por S. A. I. Dom Pedro Henrique.

III - PÁTRIA E RAÇA BRASILEIRA - Afirmação da Pátria Imperial Brasileira; sua valorização espiritual (religiosa, intelectual e moral), física e econômica. Afirmação da Raça Brasileira em todos os seus elementos tradicionais e novos integrados (filhos de estrangeiros). Solução séria e definitiva do problema negro-índio-sertanejo. Formação e valorização física, intelectual e religiosomoral nacionalista da Raça Brasileira. Definição da situação do estrangeiro dentro do Império instaurado. Reação contra todas as formas de imperialismo estrangeiro no Brasil.

IV - NOVA DIVISÂO ADMINISTRATIVA - Divisão do País em províncias menores, puramente administrativas. Educação obrigatória especial contra o espírito regionalista e intensificação do amor à cidade natal ou município, célula da Pátria Imperial. Capital no centro do Império. 
V - ORGANIZAÇÃO SINDICAL das classes profissionais de produção espiritual (religiosa, moral e intelectual) e econômica: clero, magistério, artes liberais, artes mecânicas, agricultura, comércio e indústria nacionais, e outras, com base da verdadeira representação nacional.

VI - CAPITAL NO CENTRO DO IMPÉRIO.

VII - POLÍTICA INTERNACIONAL ALTIVA E CRISTÃ.

VIII - ENTENDIMENTO ESPECIAL IBERO-AMERICANISTA (Revista PátriaNova. São Paulo, 09/1929)." 123

Alguns dos pontos desse programa são trabalhados, de uma forma ou de outra, nos textos de Salathiel de Campos desse momento em diante. Os referenciais católicos, o nacionalismo, a ideia de raça brasileira e a valorização da população negra como elemento essencial dela, são os principais pontos. A respeito do monarquismo, não é possível identificar com clareza se Salathiel passa a defendê-los após a entrada no movimento Pátria-Nova ou se já tinha afinidade com essas ideias antes. A única referência mais próxima é quando, em $O$ Homem Negro no Esporte Bandeirante, Salathiel de Campos fala da Princesa Isabel sobre o passado monarquista brasileiro em tom apologético, mas essa é uma referência bem posterior.

Nos parece, ao analisar as fontes que ora estão disponíveis, que, em um primeiro momento, Salathiel de Campos era um jornalista, católico, membro politicamente ativo da classe média e da chamada modernidade negra, possivelmente membro de congregações marianas, frequentador de bailes e festas organizados pela população negra, frequentador do Centro Cívico Palmares, e alguém que se manifestava em defesa de atletas negros. E que, só depois de se aproximar de Arlindo Veiga dos Santos, aderiu também às outras ideias elencadas no programa do movimento Pátria-Nova.

Os militantes patrianovistas atuavam em diversos meios para divulgar o movimento e constituir as bases para a volta da monarquia. A atuação junto à Frente Negra Brasileira foi apenas mais um desses meios de divulgação ${ }^{124}$, apesar da frente ter vida própria e objetivos específicos. Algo que se tornou possível graças a Veiga e também, por que não, Salathiel de Campos.

"Somos Pátria-Nova, extrema direita radical e violenta, afirmadores de Deus e sua Igreja, afirmadores da Pátria Imperial $e$ Católica, inimigos irreconciliáveis e intolerantes do

\footnotetext{
123 DOMINGUES, Petrônio. O "messias" negro? Arlindo Veiga dos Santos (1902-1978). VARIA HISTORIA, Belo Horizonte, vol. 22, no 36: p.517-536, Jul/Dez 2006. Pags. 522-523.

124 MALATIAN, Teresa. Império e Missão - um Novo Monarquismo Brasileiro. São Paulo: Companhia Editora Nacional, 2001.pag. 57
} 
burguesismo, plutocratismo e capitalismo materialista, ateu, gozador, explorador, internacionalista, judaízante e maçonizante; inimigos da república, dos partidos, do parlamentarismo, em suma do liberalismo religioso, político e econômico; enfim, tão inimigos também da anarquia bolchevista que com erros igualmente grandes pretende em vão "corrigir" a tirania da burguesia liberal, como inimigos da ordem social mentirosa, instalada em quase todo o mundo." 125

A definição da "situação do estrangeiro" e a reação contra "todas as formas do imperialismo estrangeiro", presentes no $3^{0}$ item do programa patrianovista, correspondiam, segundo Teresa Malatian, ao discurso frentenegrino baseado na dicotomia homem livre/homem escravo, "de forma a fazer do negro credor de uma nova abolição e de uma situação semelhante à do imigrante, sobretudo italiano, considerado seu rival"126. Assim entendemos melhor Arlindo Veiga quando diz:

"Cessem, por conseguinte, os mitos, e simultaneamente os excessivos louvores aos estrangeiros de ontem, italianos $e$ companhia, e faça-se justiça ao Negro" ${ }^{127}$

Do encontro entre o monarquismo patrianovista e o movimento negro que tomava forma a partir dos anos 20, surge uma luta contra a desvalorização do negro no mercado de trabalho urbano e a favor de uma integração dessa população na economia industrial que então tomava suas primeiras formas. ${ }^{128}$

A militância de Salathiel de Campos pela convocação dos jogadores negros à seleção paulista de futebol, o seu trabalho de estudar "o homem negro no esporte bandeirante", sua posterior defesa dos atletas olímpicos negros - utilizando a delegação dos EUA como referência - e suas impressões acerca da Copa de 1938, tudo que já vimos até aqui e aquilo que ainda iremos ver nesse trabalho, ganha novo sentido com o que acabamos de apresentar. Esses textos deixam de parecer uma manifestação isolada de um jornalista negro, que resolvera por bem falar de sua raça, e passa a se encaixar em um processo maior. Enquanto as cidades cresciam e a sociedade se transformava, a população

\footnotetext{
125 VEIGA DOS SANTOS, in: DOMINGUES, Petrônio. O “messias" negro? Arlindo Veiga dos Santos (19021978). VARIA HISTORIA, Belo Horizonte, vol. 22, no 36: p.517-536, Jul/Dez 2006. Pags. 522-523. Grifos nossos.

${ }^{126}$ Idem. pag. 56

${ }^{127}$ VEIGA DOS SANTOS, in MALATIAN, Teresa. Império e Missão - um Novo Monarquismo Brasileiro. São

Paulo: Companhia Editora Nacional, 2001.

128 Idem..pag. 58
} 
negra, representada por aqueles que conseguiam algum destaque, bem ou mal, tentava cavar trincheiras e conquistar maior espaço.

\subsubsection{Movimento negro}

Esse momento de ebulição - que não ficou restrito à capital, mas nela teve maior tamanho e relevância - foi sentido pelos agentes como um marco histórico, um "antes e depois". Percebemos esse sentimento quando Salathiel diz em seu livro que a "gente negra, depois de um longo período de inacção, vibra o clarim para o despertar" "129, visão compartilhada pelo ex-integrante da FNB, Raul Joviano do Amaral, ao falar dos motivos da grande adesão à frente: "a democracia não existia, o negro era republicano e era pobre, até então não tinha divisão. A partir de 30, todas as ideologias começaram a funcionar"130.

O início dos anos 30 realmente foi uma época de bastante mobilização, mas não se pode afirmar que "as ideologias não funcionavam" antes. Mesmo a Frente Negra Brasileira é parte de um processo anterior, iniciado nos anos 20, que inclui, por exemplo, a imprensa negra, uma mobilização que ocorreu, principalmente, entre 1915 e 1963 em diversos estados do país, cujo objetivo era reivindicar direitos para conquistar uma integração dos grupos negros na sociedade ${ }^{131}$. O que ocorre é que, após o golpe de Estado de 3 de outubro, quando Getúlio Vargas chega ao poder com a força das armas, a reorganização das forças políticas se deu, como é hoje, entre a esquerda e a direita. Nenhuma delas, porém, tinha como pauta as demandas urgentes da população negra ${ }^{132}$. A afirmação de Raul Joviano do Amaral faz mais sentido se lembrarmos que, observando esse cenário de abertura política em meio ao caos, a Frente Negra Brasileira foi criada para dar início a um processo de mobilização que tivesse como pauta a questão racial, deixando entre aqueles mais recentemente conscientizados uma sensação de "antes e

\footnotetext{
${ }^{129}$ Correio Paulistano, Todos os Esportes, O Homem Negro no Esporte Bandeirante, 03-10-1934, pg.7. disponível em <http://hemerotecadigital.bn.br/acervo-digital/> acesso em 12/11/2014.

130 Entrevista de Raul Joviano do Amaral, in PINTO, Regina Pahim. O Movimento Negro em São Paulo: luta e identidade. São Paulo: Editora UEPG. 2013.

${ }^{131}$ FERRARA, M. N. A imprensa negra paulista (1915-1963). Estudo monográfico. África: Revista do Centro de Estudos Africanos da USP, no6, 1983. Pg 167.

132 FONSECA, Marcus V. e DE BARROS, Soraya A. P. (orgs.) A História da Educação dos negros no Brasil. Niterói: EdUFF, 2016. Pag 336.
} 
depois", ou seja, da inação para a mobilização, para a organização que efetivamente podia fazer "as ideologias começarem a funcionar".

O sociólogo Jeffrey Alexander afirma que os movimentos sociais são respostas práticas e coerentes à distribuição desigual das privações sociais. O movimento negro do período estudado é, portanto, uma luta pela mudança nessa destruição de recompensas e sanções sociais ${ }^{133}$. Essa resposta em um movimento, encarado como único e homogêneo, não significa inexistência de conflitos. Almícar de Araújo Pereira discute se devemos utilizar o termo "movimento negro" ou "movimentos negros".

“...considerando a multiplicidade de estratégias, ações e formas de organização, a utilização do termo plural, 'movimentos negros', estaria correta. Entretanto, nesse sentido, também seria correto utilizarmos o termo 'movimentos de mulheres', por exemplo (...) Durante as pesquisas (...) foi verificado que, assim como Lélia Gonzales, as lideranças e os militantes desse movimento social se autodenominam e são denominados majoritariamente como militantes do 'movimento negro', no singular. ",134

Nesse sentido, podemos lembrar de Alan Prost quando ele encadeia um raciocínio parecido em Doze Lições sobre a História:

"Mas teremos o direito de atribuir os traços da psicologia individual a entidades coletivas? Tal transferência será legítima? (...) o historiador sente-se autorizado a dizer que, em 1914, a França assumiu determinada atitude para com a Alemanha em decorrência do que os mobilizados afirmavam na época: 'Nós estamos em guerra, a Alemanha nos declarou guerra'. Do mesmo modo, se ele faz menção aos operários é porque, em greve, estes são os primeiros a afirmar: 'Nós exigimos a satisfação das nossas reivindicações'.,"135

\footnotetext{
133 ALEXANDER, apud PEREIRA, Almícar Araújo. Mundo Negro: a constituição do movimento negro contemporâneo no Brasil (1970-1995). Tese de Doutorado). Universidade Federal Fluminense. Niterói, 2010. Pag. 81

134 Idem. Pag.82

135 PROST, Antoine. Doze Lições Sobre a História. Belo Horizonte: Autêntica. 2014. Pag 127-128
} 
Portanto, tratamos aqui do "movimento negro" como único porque assim se manifestavam os agentes naquele momento, apesar dos conflitos e disputas internos.

\section{Imprensa negra}

Se falarmos em movimento negro como qualquer mobilização de resistência da população negra, os quilombolas seriam talvez os primeiros "militantes". Porém, quando falamos de Salathiel de Campos, o movimento do qual ele fez parte tem o início nos encontros e reuniões de cidadãos negros, que passam a se organizar e se comunicar por meio dos veículos da imprensa negra. Sobre esse processo, Gilmar Luiz de Carvalho afirma que, dentro de um contexto da Primeira República, controlada pelas oligarquias cafeeiras e pela política do café-com-leite, enquanto o "capitalismo se desenvolvia no país e continuava gerando elevados lucros, consolidando o poder da elite paulista", essa imprensa:

“...continuava sua trajetória de conscientização do negro em relação à busca de sua identidade e obtenção da cidadania. $O$ caminho a ser trilhado era o do acesso à boa educação pública, ao trabalho decente, à cultura, à participação política e à almejada elevação moral. Esse período, contudo, marca o início da postura de reivindicação direta, da valorização do negro como protagonista da História, da lembrança de seu papel na sociedade e da crítica à falta de ação dos próprios irmãos "136.

Já vimos que, em 1901, quando nasce Salathiel de Campos, a chamada imprensa negra já exista, ainda que com as típicas publicações de vida curta - por dificuldades impostas pelos altos custos do papel, tinta e impressão, e pelo uso de tipografias improvisadas ${ }^{137}$. Em São Paulo, há duas mais importantes e duradouras: o Clarim d' Alvorada, iniciado em 1924 - com o qual Salathiel de Campos colaborava com trabalho

\footnotetext{
${ }^{136}$ DE CARVALHO, Gilmar. A imprensa negra paulista entre 1915 e 1937: características, mudanças e permanências. Tese (Mestrado em História). - Faculdade de Filosofia, Letras e Ciências Humanas, Universidade de São Paulo. São Paulo, p. 109. 2009 137 PINTO, Regina Pahim. O movimento negro em São Paulo: luta e identidade. Ponta Grossa: UEPG, 2013. pag 72.
} 
e dinheiro - e $A$ Voz da Raça, iniciado em 1933 pela Frente Negra Brasileira ${ }^{138}$, com o qual ele também colaborou.

Os agentes que organizaram esses veículos, como o próprio Salathiel, eram politizados e faziam circular ideias importantes para qualquer movimento político. Tinham como objetivo "combater a apatia em que viviam os homens pretos da pauliceia", como aponta Regina Pahim Pinto ao falar sobre o jornal $O$ Alfinete. Eram associações que nasceram "para lutar, já contra a incoerência de nossa gente(...)já contra a falta de apoio material", mas cuja falta de recursos não os abalou porque tinham "o entusiasmo verdadeiro", como nos lembra a mesma autora ao falar sobre $A$ Voz da Raça ${ }^{139}$.

Podemos considerar essas publicações, em todo seu recorte temporal, ao mesmo tempo como uma das bases da organização do movimento negro e um braço de atuação do mesmo. Falamos de uma cidade que, se já era uma metrópole, ainda tinha uma população de $579.033^{140}$ pessoas, das quais cerca de um terço era negra ou "parda" (termo que consta no censo). Trata-se, então, de um universo de 173 mil pessoas, a maioria das quais era analfabeta - se considerarmos a população total, nessa época, a taxa de analfabetismo chegava a $65 \%{ }^{141}$. Certamente, entre a população negra essa porcentagem era ainda maior, com o que podemos estimar que havia menos de cinquenta mil negros letrados na capital paulista. Isso explica porque, como mostra Regina Pahim Pinto, apesar de um grande número de pessoas terem colaborado, de uma forma ou de outra, com a chamada imprensa negra, "destaca-se um grupo de aproximadamente 15 militantes que realmente tiveram uma atuação mais consistente" ${ }^{142}$.

Ainda que restrita, por ser um meio de politização e troca de informações, também um espaço de sociabilidade, uma vez que eram necessárias reuniões para planejar e executar as publicações, a imprensa negra tem um papel importantíssimo na construção dos movimentos negros. Uma exemplo que muito nos interessa (e que será melhor

\footnotetext{
${ }^{138}$ DE CARVALHO, Gilmar. A imprensa negra paulista entre 1915 e 1937: características, mudanças e permanências. Tese (Mestrado em História). - Faculdade de Filosofia, Letras e Ciências Humanas, Universidade de São Paulo. São Paulo, p. 109. 2009

139139 PINTO, Regina Pahim. O movimento negro em São Paulo: luta e identidade. Ponta Grossa: UEPG, 2013. pag 77

140 IBGE, censo de 1920. Disponível em < https://censo2010.ibge.gov.br/sinopse/index.php?dados=6 > Acesso em 13/01/2017.

${ }^{141}$ Mapa do analfabetismo no Brasil. Disponível em < http://portal.inep.gov.br/documents/186968/485745/Mapa+do+analfabetismo+no+Brasil/a53ac9eec0c0-4727-b216-035c65c45e1b?version=1.3 > Acesso em 13/01/2017

142 PINTO, Regina Pahim. O movimento negro em São Paulo: luta e identidade. Ponta Grossa: UEPG, 2013. pag 69
} 
trabalho mais adiante) é a ideia de que o homem negro possuia um talento inato para a prática esportiva. Os formadores de opinião dessa imprensa feita por negros - que já podem ser considerados desde esse momento como agentes do campo político - foram pioneiros na construção dessa ideia, que pretendia marcar território ao mostrar que os negros também tinham suas qualidades e deveriam ser valorizados. Era, a essa altura, uma ferramenta de militância. Salathiel de Campos, que conviveu nesse meio, e que pode também ter sido um dos fomentadores dessa ideia de talento inato negro, levou essa reflexão por toda a sua carreira como jornalista ${ }^{143}$.

Assim como ele, há outros militantes da imprensa negra que conquistaram espaço na grande imprensa - que podemos chamar, por que não?, de imprensa branca. Dado esse número restrito de agentes, foi possível tomar conhecimento, por exemplo, de Lino Guedes, companheiro de Salathiel de Campos. As histórias desses dois jornalistas são incrivelmente parecidas, não só pela militância no movimento negro.

Gilmar Luiz de Carvalho, em A imprensa negra paulista entre 1915 e 1937, diz que Lino Guedes nasceu em Socorro, no interior de São Paulo, em 1897, filho de negros libertos. Ficou órfão de pai aos dois meses de idade e foi criado pela mãe e pela irmã, com apoio do “coronel” Olympio Gonçalves Reis. Em 1912, é contratado como revisor no Diário do Povo, em Campinas. Ao sair de lá, em 1926, fundou o jornal Progresso em São Paulo, onde também trabalhou no Jornal do Comércio, O Combate, A Razão, Correio Paulistano e Diário de São Paulo. Publicou doze livros de poesia - o primeiro e talvez mais famoso tinha o título Black. Faleceu em março de $1951^{144}$.

As semelhanças são impressionantes. Tanto Lino Guedes quanto Salathiel de Campos nasceram no interior paulista, ficaram órfãos de pai ainda bebês, começaram suas carreiras no jornalismo como revisor, ambos trabalharam no Correio Paulistano, n'O Combate e no Diário de São Paulo, ambos publicaram seus livros - um de poesia, o outro, de esporte - tendo como tema a população negra, e faleceram no mesmo ano, 1951.

Eduarda Rodrigues Costa, que analisa as poesias de Lino no artigo: Tradição popular e pertencimento étnico na poesia de Lino Guedes, diz que o jornalista “empenhava-se na elevação do afrodescendente a partir do letramento, incentivando os

\footnotetext{
${ }^{143}$ Agradeço a José Paulo Florenzano, membro da banca na defesa dessa dissertação por ter constribuído com essa informação. Vital, aliás, para entendermos melhor o posicionamento de Salathiel de Campos.

${ }^{144}$ DE CARVALHO, Gilmar. A imprensa negra paulista entre 1915 e 1937: características, mudanças e permanências. Tese (Mestrado em História). - Faculdade de Filosofia, Letras e Ciências Humanas, Universidade de São Paulo. São Paulo, p. 113. 2009
} 
poucos que eram alfabetizados" e os apresentava "um material de leitura com que se identificassem e, sobretudo, mobilizando-os em favor do reconhecimento moral perante a sociedade" $" 145$. Lino Guedes chega a São Paulo no mesmo ano em que começamos a encontrar registros da militância de Salathiel de Campos. Pelas datas, foram companheiros de trabalho em mais de um jornal. Não é possível saber se Lino Guedes, mais velho, mais experiente, e famoso por suas poesias, foi uma espécie de mentor de Salathiel de Campos, como Arlindo Veiga certamente foi. Mas é possível dizer que foram parceiros de militância.

Sabemos é que, em 1937, Salathiel se juntou à comissão organizadora de uma homenagem a Lino Guedes, noticiada, entre outros veículos, no Correio Paulistano ${ }^{146} \mathrm{e}$ na Folha da Manha $\tilde{a}^{147}$. Também faziam parte da organização: Dr. Francisco Lucrécio (que tem um depoimento público utilizado como fonte, por exemplo, por Florestan Fernandes em A integração do negro na sociedade de classes), Augusto de Oliveira, outros jornalistas como Nabor e Cayres de Brito, e Oswald Andrade (o próprio).

A participação de Salathiel de Campos na imprensa negra, aparentemente, foi menor que a de seu companheiro de trabalho e militância, Lino Guedes, mas ainda assim muito importante. Sendo jornalista, Salathiel era um dos militantes que mais tinha a colaborar com esses veículos, e o fazia através de textos e contribuições financeiras.

\section{Frente Negra Brasileira e Clube Negro de Cultura Social}

Fundada em 16 de setembro de 1931 por Arlindo Veiga dos Santos e seu irmão, Isaltino Veiga dos Santos, com participação de Salathiel de Campos entre os primeiros membros. A essa altura, a população negra da cidade de São Paulo somava $11 \%$ do total, a maioria analfabeta e morando em cortiços, trabalhando em subempregos, e com condições de saúde tão precárias que previa-se o desaparecimento dos negros. ${ }^{148}$ Nesse contexto, o movimento "ofereceu a essa população marginalizada possibilidades de organização, educação e ajuda no combate à discriminação racial", assim como "incentivou a conquista de posições na sociedade e a aquisição de bens" "149. Mas, afinal,

\footnotetext{
${ }^{145}$ COSTA, Eduarda Rogrigues. Tradição popular e pertencimento étnico na poesia de Lino Guedes. UFMG-LITERAFRO. Disponível em <www.letras.ufmg.br/literafro/>

${ }^{146}$ CORREIO PAULISTANO, Vida Social, Homenagens. 25/07/1937. Pag 8, 3acoluna.

${ }^{147}$ FOLHA DA MANHÃ, Chronica Social, Homenagens. 14/08/1937. 2a coluna.

148 Idem.

149 Idem, ibidem.
} 
Barbosa concorda que a Frente era "conservadora, expressava aspirações de negros de classe média e teve concepções políticas limitadas", tendo como grande mérito a tentativa de "dar aos afro-brasileiros condições de se integrarem à sociedade capitalista" 150 .

Para alcançar esse objetivo, uma das atuações importantes da Frente Negra Brasileira era seu projeto educacional. Quase completamente excluídos da educação formal, a maior parte dos negros ainda era analfabeta. Historicamente, a exclusão do sistema de ensino foi um dos maiores ataques à população negra, a luta pelas oportunidades educativas é um ponto em comum de várias vertentes diferentes do movimento negro, alcançando, como vemos, a mobilização por cotas nas universidades, mais aquecida a partir dos anos 80 e que só teve algumas vitórias nos últimos anos.

Como diz Petrônio Domingues em A História da Educação dos negros no Brasil, para a população negra, nesse momento, ser cidadão significava ter direitos iguais, mas diante da pouca ou nula inclusão social e das práticas de discriminação, a cidadania plena continuava distante. Para alcançar esse objetivo, buscavam através de sua atuação: "respeito, reconhecimento, dignidade, empoderamento, participação política, emprego e educação". De todas essas bandeiras, "uma das prioritárias foi a defesa da educação"151.

A própria imprensa negra, da qual falamos, incentivava a "população de cor" a procurar educação formal ${ }^{152}$, e "o maior e mais importante departamento da FNB foi o de instrução, também chamado de departamento de cultura ou intelectual". ${ }^{153} \mathrm{Nesse}$ departamento, descobrimos que não só Salathiel de Campos participava do movimento negro. Sua esposa Celisa lecionava voluntariamente na escola da FNB, localizada no bairro da Liberdade, onde moravam:

"Nos cursos, os professores davam aulas gratuitamente. Os frentenegrinos que estudavam(...)se propuseram a dar aulas. Existiam diversos professores: o Raul Amaral, o Lino Guedes, que era jornalista, Salatiel de Campos, que também era jornalista (...) Tinha a Celina Campos [sic], professora de música..."

\footnotetext{
150 Idem, ibidem.

${ }^{151}$ RODRIGUES, Petrônio. Um templo de Luz: Frente Negra Brasileira (1931-1937) e a questão da educação. IN FONSECA, Marcus V. e DE BARROS, Soraya A. P. (orgs.) A História da Educação dos negros no Brasil. Niterói: EdUFF, 2016.

152 Idem.

153 Idem, ibidem.

154 BARBOSA, Márcio. Frente Negra Brasileira: depoimentos. São Paulo: Quilombhoje, 1998.
} 
A educação era vista por estas pessoas como a principal arma na cruzada contra o preconceito. Em nossa análise, isso é importantíssimo para entender a obra de Salathiel de Campos. O que ele faz nada mais é que produzir conhecimento a respeito da população negra, para que conhecessem sua história (neste caso, no esporte), ganhando força e argumentos na luta, combatendo os racistas com informação. Entendemos aqui que o contexto da escrita do livro (1932) e de sua publicação (1934) é de uma grande mobilização dentro do movimento negro, que via a instrução como aquilo que o negro precisa.

"O negro deve procurar se libertar dos grilhões da ignorância e quebrar as algemas vergonhosas do preconceito que o faz aniquilar", pois é "na arena pedagógica que se acolhe a luta suprema da civilização" ${ }^{155}$.

Sobre Salathiel de Campos, no que diz respeito à sua própria educação, sabemos que estudou em um colégio católico quando chegou em São Paulo e que sonhava ter um diploma de advogado ${ }^{156}$. Matriculou-se na Escola de Direito de Alfenas - aparentemente, numa espécie de curso à distância, já que continuou trabalhando. "Sua luta nesta fase de um carreira cheia de tropeços, não seria menos árdua que aquela, que empreendera quando para conquistar a chave da escola, absorvia o tempo que seria necessário para conquistá-la"157. Um decreto do presidente da república fechou a instituição ${ }^{158}$, mas facultou aos alunos que se matriculassem em uma faculdade de sua cidade domicílio, ainda que fosse necessário criar vagas. Salathiel de Campos tentou se matricular em São Paulo, na mais prestigiada faculdade de Direito do país, mas:

"Em vão, Salathiel batera às portas da Faculdade de Direito de São Paulo(...)em que me pese dizê-lo, em que me dilacere a alma ter a convicção para afirmar: influiu, influiu desgraçadamente a pigmentação da pele daquele pobre aspirante a um banco nas tradicionais arcadas do Largo do São Francisco"159

\footnotetext{
155 VOZ DA RAÇA, 02/09/1933, pag 2. IN FONSECA, Marcus V. e DE BARROS, Soraya A. P. (orgs.) A História da Educação dos negros no Brasil. Niterói: EdUFF, 2016. Pag 340.

${ }^{156}$ SÃO PAULO, Diário Oficial, Requerimento no 1074.52, 15 de setembro de 1952. pag.52-53.

157 Idem.

158 Como a fonte não revela o ano, não foi possível descobrir qual foi este decreto ou mesmo qual era o presidente.

${ }^{159}$ SÃO PAULO, Diário Oficial, Requerimento no 1074.52, 15 de setembro de 1952. pag.52-53.
} 
Após essa frustrante tentativa, matriculou-se na Faculdade de Niterói, onde só conseguiu diplomar-se advogado em 1951, justamente o ano de sua morte, ao menos segundo a fonte que utilizamos para traçar os passos acadêmicos de Salathiel. ${ }^{160}$ Como não foram encontradas outras informações sobre esses fatos, em quaisquer outras fontes, não conhecemos detalhes nem das negativas e nem da diplomação.

Saindo desse rápido aprofundamento na bandeira educacional da FNB, e da janela que foi aberta para conhecermos um pouco mais da trajetória de Salathiel de Campos, voltamos às disputas políticas que estavam envolvidas em torno da Frente no período estudado.

Temos por óbvio que não há consensos dados, naturais, entre as pessoas da população negra. A visão equivocada de que as pessoas negras formam um bloco homogêneo é fruto do próprio racismo. É a ação racista que coloca milhões de pessoas sob um mesmo rótulo apenas por serem todas negras. Na introdução de seu livro Frente Negra Brasileira: depoimentos ${ }^{161}$, Márcio Barbosa cita autores como Florestan Fernandes e George Andrews, que analisam a FNB como um movimento de direita, muito por conta da atuação de seu líder, Arlindo Veiga dos Santos. Depois, explica que, na verdade, a frente abrigou diversas tendências, mas "não sem conflitos".

Dito isso, temos que essas divergências impuseram dificuldades e tornaram árdua a construção da Frente Negra Brasileira. O próprio Salathiel de Campos, ao falar sobre negros que negam sua origem, narra uma dessas dificuldades:

"Consultado um desses infelizes sobre uma possivel congregação negra, disse, demonstrando uma certa ogerisa: 'Ih! Não quero saber dessas coisas. Eu já não sou mais negro’."162

O trecho “já não sou mais negro” remete, imediatamente, à frase que Mário Filho, autor de O Negro no Futebol Brasileiro (1 ${ }^{\mathrm{a}}$ ed. 1947, $2^{\mathrm{a}}$ ed. 1964), atribuiu a Robson, um jogador do Fluminense: "Eu já fui preto e sei o que é isso". Fazendo referência a este fato, este foi o título de um artigo duplo de César Gordon Jr. ${ }^{163}$ que discute a História Social

\footnotetext{
160 Idem.

${ }^{161}$ BARBOSA, Márcio (org). Frente Negra Brasileira: depoimentos. São Paulo: Quilombhoje. 2007.

162 CORREIO PAULISTANO, O Homem Negro no Esporte Bandeirante. 06/10/1934. Pag 11, rodapé.

${ }^{163}$ GORDON JÚNIOR, Cesar. Eu já fui preto e sei o que é isso: história social dos negros no futebol brasileiro: segundo tempo. Pesquisa de Campo, Rio de Janeiro, Eduerj, n. 3/4, p. 65-78, 1996. Futebol: síntese da vida brasileira.
} 
dos negros no futebol brasileiro. Identificamos em Salathiel de Campos o mesmo afã de embranquecimento encontrado, mais tarde, em Mário Filho - como identificado por Gordon Jr. Essa é uma forma do racismo perpetuado pelos brancos introjetada pelos negros, uma das piores modalidades dessa violência.

Além disso, havia nessa ebulição política outros movimentos aparecendo na cidade de São Paulo. Um deles, muito importante na trajetória de Salathiel de Campos, foi o Clube Negro de Cultura Social, fundado às vésperas da contrarrevolução paulista de 1932 (a chamada Revolução Constitucionalista), em 1 de julho daquele ano. Ao que consta na literatura, o CNCS foi fundado após certas tensões e discordâncias dentro da FNB. Uma dos pontos de tensão foi a aproximação de Arlindo Veiga dos Santos, seu líder, com Plínio Salgado, já então um notável fascista, que em outubro (poucos meses depois da criação do CNCS) fundaria a Ação Integralista Brasileira.

George Andrews vai dizer também que a Frente Negra compartilhava com o integralismo "um insolente desdém pela democracia liberal e uma aberta admiração pelo fascismo europeu" ${ }^{\prime 64}$. O mesmo autor revela o conflito decorrente dessa aproximação com a AIB:

\section{"Entretanto, orientação fascista da Frente provou ter uma atração limitada para a população negra como um todo. $\mathrm{Na}$ medida em que a organização se aliava mais estreitamente com o integralismo (...) ela foi perdendo progressivamente o apoio tanto da classe trabalhadora quanto da classe média negras, levando os dissidentes moderados e de esquerda na cidade de São Paulo a criar o Clube Negro de Cultura Social e a pequena Frente Negra Socialista." $" 165$}

Quem melhor resume o que foi o CNCS e seu papel ao longo dos anos 30 é Petrônio Domingues ${ }^{166}$. Segundo este autor, o clube era, acima de tudo, "um pólo de

. História social dos negros no futebol brasileiro: primeiro tempo: -essa maravilhosa obra de arte fruto da misturall. Pesquisa de Campo, Rio de Janeiro, Eduerj, n. 2, p. 71-90, 1995. Futebol e cultura brasileira.

${ }^{164}$ ANDREWS, George. O protesto negro no Brasil 1888-1988. Estudos Afro-Asiáticos, (21);27-48, dezembro de 1991. Pg 34.

165 Idem.

166 DOMINGUES, Petrônio. "Paladinos da liberdade": A experiência do Clube Negro de Cultura

Social em São Paulo (1932-1938) . Revista de História, São Paulo, n. 150, p. 57-79, june 2004. ISSN 2316-9141. Disponível em: 
resistência cultural", que tinha preocupação de "reforçar laços de união étnica". Se reuniam em "bailes, nos jogos, na prática desportiva, nas apresentações cênicas, nas declamações poéticas, nas refeições coletivas, nas palestras, nas festividades de datas comemorativas"167. Tendo o Clarim D'Alvorada como seu veículo de imprensa, o CNCS teve os méritos, ainda segundo Domingues, de elevar o nível de consciência política e racial do negro paulista e de canalizar um descontentamento até então difuso.

Esse período da primeira metade dos anos 30 foi, de fato, um momento de intensa movimentação política, com atuações que aconteciam desde a formação de Ações, Movimentos, Clubes ou Frentes, até a luta armada. Nesse último caso, quem pegou em armas foram os paulistas que pretendiam derrubar aquele que os havia derrubado dois anos antes.

Não houve paz política depois que a revolução liderada por Getúlio Vargas depôs, com armas, o paulista e então presidente Washington Luís, o que ao mesmo tempo evitou a posse de outro paulista, Júlio Prestes. Foi estabelecido o governo provisório de Vargas, e era justamente isso que os paulistas queriam interromper em 1932. Pegaram em armas para conseguir (ou tentar conseguir) a convocação de uma Assembleia Nacional Constituinte, algo que estava sendo prorrogado desde 1930.

Nesse momento, os membros da FNB que aderiram à luta contra o governo varguista formaram a Legião Negra. Era a "entidade mais oponente, mais adversária da Frente", porque nesse momento as duas "se posicionaram em campos opostos"168. Quando o governo de São Paulo pediu que a FNB formasse um batalhão, seus líderes negaram. Por isso, os que queriam aderir, organizam a dissidência sob o comando de Guaraná de Santana, em acordo com coronel Goulart: deram para a Legião Negra "ali na Barra Funda, a chácara do Carvalho (...)um casarão bonito” que foi utilizado como sede. Segundo José Correia Leite, "a negrada ficou importante", porque "se teve gente que brigou naquela Revolução de 32 foram os negros" "169.

<http://www.revistas.usp.br/revhistoria/article/view/18978/21041>. Acesso em: 13 apr. 2017. doi:http://dx.doi.org/10.11606/issn.2316-9141.v0i150p57-79.

167 Idem.

168 CORREIO PAULISTANO, O Homem Negro no Esporte Bandeirante. 06/10/1934. Pag 11, rodapé.

169 Idem. 


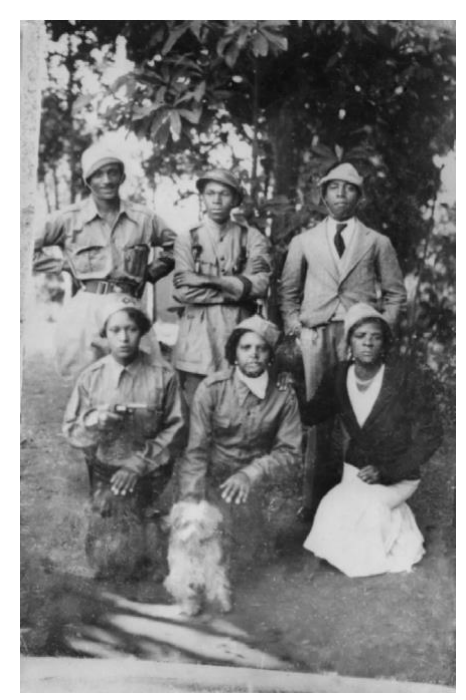

Imagem 7 - Membros da Legião Negra. O primeiro à esquerda é Benedito de Toledo, do Clube Negro de Cultura Social, fundado por José Correia Leite. ${ }^{170}$

Com o poder do Estado brasileiro em suas mãos, e com os paulistas isolados no cenário nacional, abafar a contrarrevolução paulista de 1932 não foi um grande desafio para o governo varguista. Apesar disso, como não poderia ser diferente, o caos de uma guerra civil aqueceu os ânimos e acirrou rivalidades. O estado de São Paulo, mais especificamente: o Partido Republicano Paulista, e toda a elite aristocrática paulista que o compunha. O Correio Paulistano, veículo de imprensa do partido fechado desde 1930, por motivos óbvios permaneceria fechado. Quando reaberto em 1934 - novamente contando com o trabalho de Salathiel de Campos - se manteria como um jornal de oposição.

Não só entrou em ebulição entre a política paulista e a varguista, como o movimento negro paulista de forma geral. Como dissemos, nesse mesmo ano de 1932 foi fundado o Clube Negro de Cultura Social e a Ação Integralista Brasileira, além da Legião Negra - que só existiu durante as tensões da contrarrevolução - e da pequena Frente Negra Socialista.

Salathiel de Campos nos parece, em um primeiro momento, como católico fervoroso e militante da causa negra, passou pelo o monarquismo e, depois, pelo fascismo. Por outro lado, em 1935, após mais uma das provas comemorativas do 13 de maio, que tinha como objetivo "homenagear os homens negros illustres da nossa historia", Salathiel, “frizando o gesto", falou “em nome do Clube Negro". O CNCS realizou também a "Prova

${ }^{170}$ BARBOSA, Márcio (org). Frente Negra Brasileira: depoimentos. São Paulo: Quilombhoje. 2007. Pag 78. 
Salathiel de Campos", e o homenageou em plena redação do Correio Paulistano em 1936, chamando-o de "companheiro". O jornal Clarim d'Alvorada - com o qual, já dissemos, Salathiel de Campos colaborou intelectual e financeiramente - "depois da dissidência que surgiu no seio da Frente Negra Brasileira, continuou ativo, por meio do Clube Negro de Cultura Social”, como disse Florestan Fernandes, no mesmo período em que a colaboração de Salathiel de Campos no veículo frentenegrino, A Voz da Raça, arrefece até sumir. São indício de sua aproximação maior com o CNCS do que com a FNB.

Por outro lado, levando em conta a biografia de Salathiel de Campos e os seus textos - informações que temos disponíveis - ele parece fazer parte da classe média e média baixa paulistana cujas aflições e ansiedades eram refletidas pelo fascismo do período $^{171}$. Além do que, a participação do jornalista na Ação Imperial Patrianovista revela que ele concordava - ainda que teoricamente - com a xenofobia e o nacionalismo, elementos característicos do movimento fascista. Além disso, como vimos, o CNCS tinha uma linha mais apaziguadora, de união étnica, e dedicava-se muito aos esportes, campo no qual Salathiel de Campos tinha grande destaque. E esses fatos podem explicar sua aproximação com o clube sem afastá-lo da FNB.

Essa trajetória ideológica não está totalmente clara apenas com as fontes estudadas. Dada apenas essa proximidade com o Clube Negro de Cultura Social, não podemos concluir que ele foi um dos que se afastou da Frente Negra Brasileira após a aliança com a Ação Integralista Brasileira. Temos duas alternativas possíveis: Salathiel de Campos rompe com a Frente Negra Brasileira após a aliança com a Ação Integralista Brasileira e vai militar no Clube Negro de Cultura Social; ou, ainda na Frente Negra, alinhado com os ideias fascistas, manteve bom relacionamento com outras vertentes do movimento negro. Seja como for, Salathiel de Campos seguiu à risca, dentro do campo esportivo e do campo político, o objetivo que fora traçado: "A Frente Negra Brasileira tem como objetivo a integralização absoluta, completa, do negro em toda a vida brasileira"

\footnotetext{
${ }^{171}$ ANDREWS, George. O protesto negro no Brasil 1888-1988. Estudos Afro-Asiáticos, (21);27-48, dezembro de 1991. Pg 34.
} 


\section{Capítulo 2: O Homem Negro no Esporte Bandeirante (1931-1934)}

"Ha um velho brocardo popular que affirma não se poder 'falar de cadeia perto de criminoso'. Guardadas as proporções necessarias e o lado pratico, chega-se mesmo a afirmar que no BRASIL não se póde falar de côr da epiderme.'

Salathiel de Campos ${ }^{172}$

No dia três de outubro de 1934, o Correio Paulistano anuncia a publicação de "uma nova modalidade: a publicação de um livro esportivo". A estreia se daria com "uma obra inédita", do "prezado companheiro de redação Salathiel Campos". No anúncio, porém, não se fala de raça. Quem quer que o tenha escrito driblou o termo e se referiu a ele como "o assumpto a que se propoz", mas é categórico ao afirmar que o leitor terá valioso subsídio não para entender a história do negro, mas sim do "esporte paulista"

\section{O homem negro no esporte bandeirante}

Por SALATHIEL CAMPOS

Imagem 8 - Cabeçalho utilizado na publicação de todos os 17 capítulos do livro de Salathiel de Campos.

Um ano antes de escrever este livro, Salathiel de Campos já chegara a chefe da redação esportiva do Correio da Tarde ${ }^{174}$, posição que teria também no Correio Paulistano um ano após publicá-lo, em $1935^{175}$. Como sabemos, este não foi o primeiro livro deste jornalista em ascensão. Depois de ter publicado a coletânea sobre Ciclismo em Motociclismo (1926), publica, em 1931 ${ }^{176}$, junto a Licinio Motta, seu sócio na Empresa

\footnotetext{
172 Correio Paulistano, Todos os Esportes, O Homem Negro no Esporte Bandeirante, 05-10-1934, pg.7. disponível em <http://hemerotecadigital.bn.br/acervo-digital/> acesso em 12/11/2014.

${ }^{173}$ Correio Paulistano, Todos os Esportes, O Homem Negro no Esporte Bandeirante, 03-10-1934, pg.7, rodapé. disponível em <http://hemerotecadigital.bn.br/acervo-digital/> acesso em 12/11/2014.

${ }^{174}$ Diário da Noite Segunda Edição, 28/12/1931, pag 7. disponível em <http://hemerotecadigital.bn.br/acervo-digital/> acesso em 22/12/2015.

${ }^{175}$ Correio Paulistano, 04/12/1935, pag 6. disponível em <http://hemerotecadigital.bn.br/acervodigital/> acesso em 22/12/2015.

${ }^{176}$ Diário da Noite Segunda Edição, Publicações Esportivas. 21/10/1931, pag 7.
} 
de Jornalismo e Informações Gerais, um conjunto de biografias organizado em um livro chamado Os Nossos Campeões ${ }^{177}$.

Como dito pelo próprio Salathiel de Campos mais tarde em O Homem Negro no Esporte Bandeirante, nesse livro ele já se dedicava a incluir atletas negros e a debater a questão do preconceito. Mostra indignação quando diz não compreender como a população que fora a mais importante na construção do país podia ser a mais discriminada e oprimida. Assume que alguns negros jogaram no futebol paulista, mas o fizeram em "situação especial e privilegiada" e escondiam a "descendência materna ou paterna, negra". Afirma a necessidade de "quebrar esse estado apprehensivo e ridiculo de um preconceito que não poderia existir" e pede que "aparecessem no nosso futebol official elementos negros vindos da grande massa”.

Está tudo ai. O mote principal de O Homem Negro no Esporte Bandeirante já aparecia na coletânea Nossos Campeões. A pesquisa do primeiro livro certamente foi aproveitada no segundo. Os argumentos que sustentam as opiniões mais contundentes, também. Há uma outra semelhança entre os livros: ambos tem como recorte único a história do estado de São Paulo.

\subsection{O livro}

Publicado entre os dias 3 de outubro e 28 de novembro de 1934 no Correio Paulistano, em dezessete colunas de rodapé, como já dissemos, o livro fora escrito em $1932^{178}$. O autor tinha 31 anos e já militava na imprensa, como era costume se dizer na época, há dez anos. A essa altura, já era Salathiel de Campos, o jornalista, o escritor, e não mais Thylba, o repórter do futebol de várzea. E assim assinava seus textos.

Antes de falar da obra, precisamos falar um pouco sobre o veículo que a publicou.

O Correio Paulistano foi fundado em 1854, o primeiro diário de São Paulo e apenas o terceiro do país. No início, tinha tendência liberal. Em suas páginas, defendeu a abolição da escravatura e a causa republicana. Após um período atrelado ao Partido

\footnotetext{
177 Esta pesquisa se dedicou mais ao livro O Homem Negro no Esporte Bandeirante do que às outras publicações de Salathiel de Campos. Para pesquisas que busquem aprofundar a coletânea Nossos Campeões, o caminho é procurar no acervo do jornal $A$ Gazeta pelo título do livro, uma vez que as colunas publicadas no jornal que fazem parte dessa coletânea também recebiam esse nome. Os anos imediatamente anteriores a 1931 - provavelmente, essas publicações aconteceram em algum momento entre 1926 e 1931.

178 Correio Paulistano, Todos os Esportes, O Homem Negro no Esporte Bandeirante, 03-10-1934, pg.7, rodapé. disponível em <http://hemerotecadigital.bn.br/acervo-digital/> acesso em 12/11/2014.
} 
Conservador, em 1890 o jornal foi tornado órgão oficial do Partido Republicano Paulista. Apesar de ser dirigido por oligarcas tradicionalistas, reconheceu o vanguardismo da semana de arte moderna de 1922.

Após as disputas de 1930, Getúlio Vargas sai vitorioso, chega ao poder e, como o fez com outros veículos, fecha o Correio Paulistano - justamente por ser o canal de comunicação de seus adversários políticos, o Partido Republicano Paulista. As oficinas foram incorporadas ao patrimônio do Estado e, durante os embates de 1932, o PRP não teve o seu jornal. Em 1934, o jornal foi reaberto, com direito a comemoração e até uma missa em ação de graças, exatamente um dia antes do início da publicação de $O H N E B$.

Falamos aqui de um momento de virada nas interpretações a respeito da história do Brasil, especialmente no estado de São Paulo. Salathiel de Campos estava imerso nesse contexto e fez parte dele de forma bastante direta, ainda mais por fazer parte da imprensa como funcionário do Correio Paulistano. Salathiel não fala da história do negro no esporte de seu país. Não se pretende nacional, mas sim paulista. Ou melhor: bandeirante.

\subsubsection{A história do Bandeirante}

Após a independência do Brasil, em 1822, entre os cultos do país surge o debate a respeito da inexistência de uma História propriamente brasileira, escrita por brasileiros. Havia apenas o que Portugal narrava como história da colônia. Nesse esforço de criar uma história nacional, em 1838 é criado o Instituto Histórico e Geográfico Brasileiro. Sete anos depois, em 1845, é organizado um concurso por D. Pedro II nomeado: Como se deve escrever a História do Brasil?

Apesar da pretensa brasilidade, o vencedor foi um alemão, Karl Friedrich Von Martius. Seu livro, que leva o nome do concurso, durante anos foi a base da historiografia brasiliana ${ }^{179}$. Não consta nessa obra a existência dos bandeirantes (e nem dos negros, aliás), até porque esse termo não existia como o conhecemos. Os homens que haviam caminhado pelo interior do território lusitano no Novo Mundo, como batizado por Américo Vespúcio, eram conhecidos como paulistas ou sertanistas, os homens do “desertão", ou "sertão".

São Paulo já havia conquistado papel de destaque nas trocas internas do país desde a virada do século XVII para o XVIII. Mas, quando enriquece com as lavouras de café -

\footnotetext{
${ }^{179}$ VON MARTIUS, Karl Friedrich Philipp. Como se deve escrever a história do Brasil, Coleção Capistrano de Abreu, vol 1, Rio de Janeiro: IHGB.
} 
sustentadas pelo trabalho de negros escravizados e, depois, alijando a população negra do trabalho remunerado, pelo trabalho de imigrantes - sua elite financeira e política decide buscar, ou construir, uma nova história, sua própria história. Em 1894 é fundado o Instituto Histórico e Geográfico de São Paulo, repetindo o instituto nacional de 1838. Então, nas primeiras décadas do século XX, os paulistas começam a reconstruir o seu passado.

Nos anos 20, com o Museu do Ipiranga como centro desse movimento intelectual, os paulistas reescrevem a história do Brasil ou, pelo menos, a história de seu estado, em oposição à história escrita na capital. É inventada, nesse momento, a mitologia bandeirante. Os piratas do sertão, descalços, maltrapilhos, falantes quase que exclusivamente de tupi, caçadores de índios, se tornaram, ao longo dessas primeiras décadas do século XX, pomposas figuras vestidas à europeia, que chegam a ser elegantes, calçados com botas e usando chapéus, barbas cheias e saudáveis, olhos fixos e decididos - como mostra o quadro de Benedito Calixto que representa Domingos Jorge Velho. A "gente bárbara, que vive do que rouba", como disse Caetano de Melo e Castro ${ }^{180}$, foi apresentada como uma gente determinada, heroica até, que vivia entre as aventuras no sertão e as disputas políticas com a coroa e os jesuítas, como nos textos de Taunay ${ }^{181}$.

Outro processo, irmão mais novo deste, se desenrola após a chegada de Getúlio Vargas ao poder. Mais especificamente, após 1932. A elite econômica e política do estado, donos de imóveis, jornais, ferrovias e fazendas de café, organizada no Partido Republicano Paulista, havia se mobilizado contra o governo varguista, que impedira o paulista Julio Prestes de assumir a presidência da República em 1930. A população foi convocada a pegar em armas, uma intensa propaganda foi disseminada, utilizando, principalmente, recursos visuais para que a mensagem chegasse a todos daquela população majoritariamente analfabeta. Campanhas foram feitas para arrecadar dinheiro aos combatentes de São Paulo: Ouro para o bem de São Paulo! O movimento negro participou com a Legião Negra, dissidência da Frente Negra, como já dissemos, que pegou em armas e lutou para defender os interesses paulistas. Às mulheres foi relegado o papel de costureiras, enfermeiras e cozinheiras. Algumas, a despeito da divisão de tarefas machista e da liderança exclusivamente masculina, não aceitaram ficar em segundo plano

\footnotetext{
${ }^{180}$ IOKOI, Hilda M. G. (coord.). Ser índio hoje. São Paulo: Edições Loyola. 1998.

181 TAUNAY, Afonso de E. Historia Geral das Bandeiras Paulistas. São Paulo: Typ. Ideal H.L. Canton. 1927.
} 
e, de forma importante, participaram da batalha - como Maria Stella Sguassábia, Maria José Bezerra e Carlota Pereira de Queiroz ${ }^{182}$.

Os auto proclamados constitucionalistas saíram derrotados e Getúlio Vargas ainda se manteria no poder, ininterruptamente, por mais 13 anos. Após perder nas armas, São Paulo cria seus novos símbolos, com os mártires do combate, inaugura o feriado e as comemorações de 9 de julho, e começa a buscar um outro tipo de vitória para o estado.

É nesse contexto que os paulistas, liderados pelo interventor nomeado por Vargas, Armando Salles de Oliveira, e Júlio de Mesquita Filho fundam a Universidade de São Paulo, instituição na qual essa pesquisa é realizada, cujo lema é Scientia Vinces ("Vencerás pela ciência"), em 1934. O jornal dos Mesquita até hoje mostra sua intenção de rever a história dessa derrota, demonstrando ao mesmo tempo orgulho e ressentimento. Ainda em 2016, O Estado de São Paulo publica o especial: Revolução de 1932: derrota militar, vitória política. No bigode da matéria: "Rebeldes paulistas enfrentaram as tropas federais de Getúlio Vargas, de 9 de julho a 4 de outubro; perderam nas trincheiras, mas comemoraram o sucesso de seus ideais". ${ }^{183}$ Sobre a USP, esse mesmo texto diz:

"A USP, em grande parte, não foi pensada como reação à ditadura, mas como superação do vazio cultural que a ditadura representava e a Revolução demonstrara, observou o sociólogo e professor emérito da universidade, José de Souza Martins. A USP seria a imensa ponte entre a barbárie e a civilização, como de fato foi”, disse o sociólogo em entrevista ao Estado, em julho de 2012"184

Sendo o Correio Paulistano o órgão de imprensa do Partido Republicano Paulista, podemos supor que sua pauta editorial estava alinhada com esse projeto. Assim, entendemos melhor a publicação de $O H N E B$. Na perspectiva de Salathiel de Campos, uma oportunidade apresentar informações como forma de combater o racismo, criar símbolos e mitos negros, militar em um espaço de destaque da imprensa paulista e executar os objetivos traçados pelos movimentos sociais dos quais participava. $\mathrm{Na}$

\footnotetext{
182 CAPELATO, Maria Helena. O movimento de 1932: a causa paulista. São Paulo: Brasiliense, 1981.

183 MAYRINK, José Maria. Revolução de 1932: derrota militar, vitória política. O Estado de São Paulo, 09/07/2016. Disponível em <http://sao-paulo.estadao.com.br/noticias/geral,revolucao-de-1932derrota-militar-vitoria-politica,10000061815> Acesso em 05/08/2017.

184 Idem
} 
perspectiva do jornal, uma oportunidade de valorizar a história do estado, desenvolver conhecimento sobre a autoproclamada sociedade bandeirante, e colaborar ainda com o projeto de superação do passado agrário e racista, uma forma de evitar qualquer enfrentamento com a população negra e construir uma nova imagem da elite local.

Explicada a razão do atraso de dois anos entre a redação do texto e sua publicação, uma das primeiras questões que se apresentam é: algo mudou entre uma versão e outra? Não é possível saber, já que não tivemos acesso ao original. De qualquer forma, conhecemos integralmente o texto que veio a público, e qualquer análise sobre os elementos que tornaram possível sua existência e sobre os efeitos decorrentes de sua publicação deve mesmo ser feita partindo da versão conhecida pela época. Ainda assim, vale ressaltar que, se houve alguma mudança, se o texto de 1932 foi tolhido pelo jornal, a versão publicada não deixou de ser polêmica, incisiva e corajosa.

No meio do caminho, em 1933, é publicado o clássico Casa Grande e Senzala, de Gilberto Freyre, livro que teve enorme repercussão na sociedade brasileira da época e que foi a mais importante publicação do período a tratar a miscigenação como um fator positivo e elaborar ideias - algumas já defendidas anteriormente e outras novas - de uma suposta raça brasileira, mistura de negros, índios e portugueses, em um caldeamento original e especial de raças. Já vimos essa tese quando apresentada no manifesto do Movimento Pátria Nova e repetida pela Frente Negra Brasileira, movimentos dos quais Salathiel de Campos participou e que foram anteriores à publicação de Freyre. No texto do livro, não há qualquer citação ao sociólogo pernambucano. Ainda assim, não podemos descartar que um jornalista interessado, militante, intelectual, que trabalhava na pesquisa, redação e revisão de seu livro e que morava em uma metrópole como São Paulo, tenha tido acesso ao livro de Gilberto Freyre.

Dúvidas sobre influências e bibliografia à parte, temos uma obra valiosíssima e muito rica a ser analisada, que abre muitas chaves de discussão e aciona vários processos daquela época: o racismo e o preconceito, o mito da democracia racial, a existência de uma raça brasileira, a integração da população negra, a profissionalização do futebol, os mitos de origem do futebol brasileiro e paulista, a oposição futebol de elite versus futebol de várzea, o discurso de valorização que atribui qualidades inatas à população negra, a ideia de miscigenação como algo positivo, o nacionalismo e o patriotismo e, finalmente - deixando de fora ainda alguns temas - a visão estética do espetáculo futebolístico na análise da prática esportiva de negros como Petronilho e Tatú. 
Escrito em meio à já referida ebulição política da contrarrevolução paulista de 32, que tentava manter o poder e a influência dos oligarcas paulistas, o livro de Salathiel de Campos valoriza a história do estado, exalta a grandiosidade e a riqueza da região, fala da elite paulista sem problematizá-la, sem questionar sua existência ou seus discursos, mas exaltando sua condição intelectual, social e, principalmente, moral.

Logo de saída, Salathiel anuncia seu lugar em um movimento mais amplo e mostra um pouco os objetivos do livro. Primeiro, torna explícitos os motivos do "nosso aparecimento". Com "nosso", fica a dúvida se ele se refere aos militantes que lutam contra o "preconceito de côr", como ele chama, o que incluiria Leopoldo Sant'Anna, citado já nos primeiros parágrafos, ou se à população negra apenas. Salathiel de Campos demonstra clareza de responsabilidade e posicionamento. Primeiro, no campo esportivo, quando diz que a:

\begin{abstract}
"literatura esportiva de São Paulo, embora ainda pobre comparativamente ao ponto progressivo alcançado pelo esporte entre nós, não possue todos os elementos informativos para os que se abalançarem, um dia, a traçar mais profundamente a historia de nossos esportes ou determinar o concurso de cada elemento e o limite dessa participação" 185
\end{abstract}

Depois, no campo político, por meio da militância do movimento negro, ao mesmo tempo demonstrando uma exaltação patriótica do Brasil:

"O panorama da vida atual da nacionalidade vem facilitar $e$ mesmo exigir a arregimentação de várias correntes para se definirem a ordem de coisas.

A gente negra, depois de um longo período de inacção, vibra o clarim para o despertar, chamando a postos todos os seus elementos, afim de demonstrar, a todos os que não comprehendem, ou por estultice fingem não comprehender, os esforços inauditos da raça que, durante quasi quatrocentos annos(...)regou com seu suor, com as suas lagrimas e com o seu sangue generoso estas terras bemditas de Santa Cruz, coedificando esse Brasil immenso e rico." 186

E acrescenta que não está sozinho:

"Alguns negros têm augmentado a bibliotheca que se inicia neste novo cyclo com obras poeticas, musicaes, literarias ou philosophicas.

\footnotetext{
${ }^{185}$ Correio Paulistano, Caderno de Esportes, O Homem Negro no Esporte Bandeirante, 03-10-1934, pg.7. disponível em <http://hemerotecadigital.bn.br/acervo-digital/> acesso em 12/11/2014.

186 Idem
} 
E viemos egualmente em auxílio da raça, modesta e humilde dentro de sua nobreza e operosidade. "187

Esses trechos citados mostram que o jornalista não fala apenas dos negros jogadores de futebol - aqueles que conseguiram conquistar certo espaço no futebol oficial - mas trata do assunto como parte de um grupo mais amplo, que busca conquistar um espaço na sociedade de forma geral. Logo nos primeiros trechos do seu livro, Salathiel de Campos se declara como negro, parte de um movimento geral da população negra, como agente do campo esportivo, e assume os esforços que o cabem para aumentar a "bibliotheca que se inicia neste novo cyclo". Como "novo ciclo" ele se refere ao sentimento, já tratado aqui, de que as "ideologias começaram a funcionar" e a população negra "saiu da inacção".

Salathiel Campos identificou a história do negro no esporte como uma lacuna a ser preenchida, algo que se confirma facilmente ao analisar a bibliografia existente na época. O projeto do livro, segundo Salathiel, já vinha sendo alimentado "ha longos annos" - desde 1924 - com o "desejo de ser uteis ao futuro historiador" - e, podemos afirmar, de fato o é, e muito. O próprio autor, na década de 30, já considerava que esse tema e esses fatos eram "quasi ignorados ou esquecidos". O jornalista demonstra com clareza a ascensão do movimento negro daquela época, que "vibra o clarim para o despertar", lutando para que haja o reconhecimento merecido por ter regado "com seu suor, com as lagrimas e com seu sangue generoso" as terras do país ao edificar sua riqueza e imensidão.

Conseguir entrada no futebol oficial era um objetivo pelo qual lutar, uma vez que estava posta a barreira do preconceito. Mais uma entre tantas lutas da Frente Negra Brasileira, como, por exemplo, entrar nos ringues de patinação:

"Nos rinques de patinação, a partir de 1934, devido às constantes denúncias feitas pelos ativistas da Frente Negra Brasileira e a emissão de uma nota do chefe de polícia Cordeiro de Farias, o local que não aceitasse usuários negros seria fechado, como de fato ocorreu" 188

Ou mesmo trabalhar na Guarda Civil:

\footnotetext{
187 Idem, ibidem.

188 BARBOSA, Márcio. Frente Negra Brasileira: depoimentos. São Paulo: Quilombhoje, 1998. Pag.54.
} 
“Trabalhar na Guarda Civil paulistana era uma reivindicação dos grupos negros organizados desde 1928, porém suas queixas de discriminação não surtiam efeito. Até que, entre 1932 e 1933, baseados na Lei dos 2/3, que obrigava a contratação de dois terços de trabalhadores nacionais nas empresas do país, os ativistas da Frente Negra Brasileira estiveram no Rio de Janeiro e conseguiram de Getúlio Vargas um documento que orientava a Guarda Civil contratar também homens negros" "189

Esses são exemplos de reivindicações do movimento negro que buscavam alguma oportunidade de entrada no mundo do trabalho, senão por assimilação e convivência harmoniosa, pelo menos por ter posto fim às restrições. Ao menos no começo de sua trajetória, é exatamente essa a abordagem de Salathiel de Campos, como vimos na campanha de 1926 n'A Gazeta e no livro Os Nossos Campeões. A partir do OHNEB, novas nuances começam a aparecer.

Podemos entender o livro como uma peça de militância, um trabalho encarado como missão dentro de um movimento que busca criar sua identidade, identificar seus ídolos, seus símbolos e suas referências, preenchendo, nesse processo, as lacunas da história deixadas por aqueles que não se preocuparam em estudar a população negra, ou melhor, que estudaram a história do estado e do país sem levar em conta essa grande parcela da população. Isso fica evidente no trecho utilizado como epígrafe, quando Salathiel compara essa questão com "falar de cadeia perto de criminoso". Com uma dose de ironia, na visão de Salathiel de Campos: a cor da pele é uma cadeia, temida pelos racistas, os criminosos, mas vivida apenas pelos próprios negros. Desse medo decorre o tabu sobre o assunto, dessa cadeia onde não estão presos os verdadeiros criminosos. Essa luta é abraçada por Salathiel de Campos em um jornal de grande circulação, aproveitando o espaço que conquistou para tentar trazer consigo o restante da população negra. Ou, pelo menos, aqueles que se reconhecessem como negros e tivessem dotes físicos, instrucionais e morais.

Mas não é só o Salathiel de Campos militante que escreve. Há neste livro uma estrutura acadêmica e, assim como acontece no livro O Negro no Futebol Brasileiro, de Mário Filho, publicado mais de dez anos depois, há um quê de épico, sendo o negro o

189 Idem, pag. 55. 
herói. A seguir, tentaremos analisar o texto observando essas três nuances sempre que elas se manifestarem.

\subsubsection{Entre o acadêmico, o militante e o épico}

A narrativa apresentada por Salathiel de Campos pode ser lida de várias formas. Pode ser visto como um estudo acadêmico, apresentando uma tese: o valor inato do homem negro para a prática esportiva e sua contribuição histórica para a construção da pátria e da raça brasileiras; uma antítese: a desvalorização dos "elementos negros" e o receio de incluí-los em qualquer campo que fosse, devido a uma suposta falta de valores morais; e uma síntese: os negros, desde que bem selecionados, instruídos moralmente e treinados técnica e fisicamente, têm um valor imenso para o esporte paulista, que o racismo evita que seja aproveitado. Nessa leitura, Salathiel de Campos pode ser entendido como um intelectual orgânico, conceito elaborado por Antônio Gramsci para pensar a relação de conflito entre classes sociais mas que, aqui, poderia ser aplicado em contexto de conflito racial.

Pode ser visto como um texto panfletário de militância - sem nenhuma conotação pejorativa - se observarmos todas as semelhanças entre a argumentação de seu autor e o discurso dos movimentos patrianovista e negro. Salta aos olhos o discurso patrióticonacionalista, a defesa de valores morais, a exaltação do negro como detentor de qualidades físicas únicas, maior responsável pela riqueza nacional, e principal elemento da propalada "raça brasileira", assim como a defesa da inclusão dessas pessoas na vida esportiva e social do futebol paulista. Nessa leitura, Salathiel de Campos seria um braço ativo de Arlindo Veiga dos Santos atuando no campo esportivo. Um militante dedicado que utiliza seu intelecto e o espaço aberto em sua profissão para militar em prol da causa que defende.

Por fim, este livro pode ser visto como uma epopeia negra. O herói - o homem negro - recebe o chamado à aventura - o anseio pela entrada no futebol oficial. Recusa o chamado - quando prefere a várzea ao preconceito da APEA. Finalmente, sai de sua comunidade - o futebol de várzea - e alcança uma comunidade outra - o futebol oficial. Passa, então, pela provação suprema - os jogos nos quais os jogadores negros são escalados - e conquista a redenção - o ótimo desempenho. E, por fim, faz o caminho de volta com o elixir - os jogadores negros que, já não alcançando o mesmo desempenho, são esquecidos e voltam à sua comunidade, mas que deixam como legado um espaço 
aberto para outros jogadores negros no futebol oficial. Nessa análise, o livro faz parte não só da militância em si, mas também do importante processo de construção de símbolos negros.

O que nos parece é que o livro é tudo isso ao mesmo tempo: uma pesquisa acadêmica, um panfleto de militância política e uma narrativa épica. O que apenas confirma o grande valor desta obra para a historiografia brasileira, não só esportiva.

\section{2. "Bulira em casa de maribondos"}

"O trabalho é arduo, bem o sabemos, e o assumpto, melindrosissimo(...) Muito mais difficil do que se pensa, é focalizar no Brasil uma questão racial. Chovem doestos e censuras sobre as apreciações que se emitam(...)Dirse-ia que o articulista 'bulira em casa de maribondos'..."

Salathiel de Campos ${ }^{190}$

Se falar da cor da pele num país como o Brasil era como falar de cadeia perto de criminoso, seria uma fonte de problemas para aquele que tocasse no assunto. Era como mexer em uma caixa de marimbondos, como disse Salathiel, o que significa dizer: seria necessária muita coragem para tocá-la (iniciar o debate), resistência para continuar enquanto ferroado (manter seu posicionamento sem ceder) e força para superar as sequelas (enfrentar as consequências de ter aberto o debate e se mantido firme na defesa da população negra).

Também chama a atenção o fato de Salathiel não poupar palavras ao dizer que há quem não compreenda, ou por tolice finja não compreender, os esforços da população negra e a urgência de sua integração na sociedade, dada a importância histórica dessa população. Está feita aqui uma divisão: o "nós”, quando Salathiel fala dos negros e das pessoas dedicadas a auxiliá-los; e "eles", as pessoas que resistem à entrada do negro na sociedade e ignoram ou fingem ignorância a esse respeito. Essa divisão de Salathiel nada tinha a ver com classes sociais, ele critica com o mesmo tom os negros pobres que negam sua descendência e os fidalgos, dirigentes de clubes de futebol, que proibiam em seus estatutos a participação de "pessoas de côr".

\footnotetext{
${ }^{190}$ Correio Paulistano, Todos os Esportes, O Homem Negro no Esporte Bandeirante, 03-10-1934, pg.7. disponível em <http://hemerotecadigital.bn.br/acervo-digital/> acesso em 12/11/2014.
} 
Estabelecida essa oposição, Salathiel revela clareza a respeito da sua importância enquanto negro, militante, politizado, letrado, com um emprego na imprensa e espaço para se posicionar frente à sociedade. Reconhecendo que se trata de um tema sensível e polêmico, ele revela que o animou o início do "modesto trabalho" a possibilidade de "prestar dois serviços":

“um á nossa literatura esportiva, alinhando mais um volume para futura consulta; outro á nossa raça que não conta, infelizmente, com muitos elementos que, como nós, estão em actividade diaria nos ramos esportivos para dizer-lhe o quanto os negros tambem têm feito pelo progresso do esporte em São Paulo..."

O objeto de estudo se revela ao historiador, declara sua posição privilegiada e sua missão. Se propõe a cumprir esta última como jornalista esportivo e como negro. Salathiel de Campos, então, se propõe a dizer "algumas verdades" e citar "nominalmente factos que talvez não agradem a este ou áquelle", e sobre o desagrado diz que "não nos cabe culpa alguma". Ao acrescentar que as "coisas serão atacadas pelo lado exacto e delle não podemos desviar", diz também que só evitará dar nome aos bois, ou aos racistas, quando isso implicar em acusações de partidarismo e, mesmo com esse cuidado, "surgirão naturalmente os descontentes na pretensão de demolir a verdade"192. O drible nas acusações de partidarismo é uma espécie de proteção da legitimidade do seu texto. Uma vez que Salathiel é membro fundador do movimento patrianovista, um declarado monarquista, seu importante texto ficaria vulnerável a acusações dessa ordem, que para opinião pública poderiam colocar o livro todo sob suspeita de um simples ataque à República e aos republicanos.

O autor faz neste livro o que fez em toda sua carreira, antes e depois: colocou como prioridade a causa negra, a luta contra o "preconceito de côr". Não falava em suas colunas sobre monarquismo, ao falar dos fascistas (como faria mais tarde, durante a $2^{\mathrm{a}}$ Guerra Mundial) não deixava claro o seu posicionamento, não criticava a república ou mesmo o governo Vargas, o que seria natural por se tratar, certa medida, de um

\footnotetext{
${ }^{191}$ Correio Paulistano, Todos os Esportes, O Homem Negro no Esporte Bandeirante, 03-10-1934, pg.7. disponível em <http://hemerotecadigital.bn.br/acervo-digital/> acesso em 12/11/2014. .

192 Correio Paulistano, Todos os Esportes, O Homem Negro no Esporte Bandeirante, 03-10-1934, pg.7. disponível em <http://hemerotecadigital.bn.br/acervo-digital/> acesso em 12/11/2014.
} 
funcionário indireto do Partido Republicano Paulista. O único tema tratado por ele com contundência foi a questão racial.

A posição de qualquer pessoa negra, ainda que fosse um jornalista promissor numa carreira ascendente, era geralmente alvo de críticas que não existiriam caso a pessoa em questão fosse branca - como acontece até hoje. No capítulo sete de $O H N E B$, o autor cita um jogador negro que teria dito: "Nada, minha gente. Quando um negro entra numa turma de brancos, é porque é bom de facto". Vemos que, ontem e hoje, à população negra são impostos certos cuidados. Além da falta de oportunidades, os negros que, de alguma forma, conseguem entrada na sociedade têm de superar sarrafos mais altos.

Um indício gritante do preconceito que expunha a população negra a ser criticada mesmo sem qualquer motivo é a mudança da visão a respeito dos praticantes de futebol. No início, e isso até fins dos anos 20, os jogadores eram vistos como sportsmen, cavalheiros de alta estirpe, que praticavam o esporte como um exercício de civilidade. Após a longa luta pela integração do negro, da qual Salathiel de Campos participou e que será exposta nesta pesquisa com maiores detalhes, já com negros e mestiços entre os profissionais do futebol:

"Para os teóricos, os jogadores brasileiros eram imaturos $e$ ignorantes. Eram vistos como descontrolados, com instabilidades no sistema nervoso, sujeitos aos instintos e paixões." 193

Com a participação do negro ampliada, a visão a respeito dos atletas muda drasticamente. É claro que devemos ponderar a certa distância no tempo entre uma visão e outra, o que acarreta mudanças outras que não apenas a entrada do negro nos plantéis. Ainda assim, este é mais um indício de como a população negra era obrigada a se defender em diversas frentes para se proteger de discursos racistas que não cessavam em momento algum.

O jornalista parece ter escrito seu texto em uma posição conflituosa: por um lado, deveria atacar a todos que se opunham a um projeto de integração do negro, mas, por outro, ao fazê-lo correria o risco de ser taxado de partidário, panfletário, ou qualquer adjetivo que deslegitimasse sua obra, esvaziasse sua importância e enfraquecesse seu potencial dentro da militância.

"Paciencia", diz ele ao fim da introdução.

${ }^{193}$ DE SOUZA, Denaldo Alchorne. O Brasil entra em campo, Construções e reconstruções da identidade nacional (1930-1947). São Paulo: Annablume, 2008. Pag 95. 


\subsubsection{O futebol e a raça}

Salathiel de Campos era, acima de tudo, um defensor de múltiplas modalidades. Escreveu, como vimos, sobre ciclismo e motociclismo, comentava e jogava basquete (ou "cestobol") e atletismo (ou "pedestrianismo"), conhecia muito de boxe e organizava eventos dos mais variados esportes. Ainda assim, não deixava de ressaltar que o futebol é, essencialmente, um esporte que pode ser praticado por todos, e por isso o valorizava de uma forma especial. Há esportes que exigem uma boa condição financeira para serem praticados, como a esgrima, que:

"necessita de local apropriamente; o remo e a natação, uma aprendizagem especial; o tennis, esporte de elementos de boa posse material; o cyclo-motocyclismo também é dispendioso, o mesmo se dando com o cestobol.

(...)

A condição economica do homem negro, no geral, não lhe permitte dedicar-se a outros esportes dispendiosos, bem como lhe estão fechados os caminhos para esses esportes que demandam tempo para aprendizado e treinos methodicos. "194

Raro eram os negros que puderam educar seus filhos em uma escola regular, mais raros ainda aqueles que chegaram à universidade - como lembra Salathiel que, ele mesmo, viu as portas das universidade se fecharem. Por isso, defende o jornalista, o homem negro se dedicava a esportes "mais faceis e em voga":

"O futebol é o esporte que faz vibrar durante longo espaço e por isso mesmo é o mais popular; e para a sua prática, a indumentária é simples. As qualidades para cultival-o são inatas: agilidade, vontade e intelligencia." 195

Na visão de Salathiel de Campos, no futebol são acionadas qualidades inatas, não desenvolvidas por treino, repetição, preparação física, "aprendizado e treinos methodicos". Claro que, pensando sobre o assunto no século XXI, já identificamos uma mudança grande nesse discurso. Sabemos que, hoje, a construção da ideia de futebol moderno se dá nessas bases: treinos táticos, preparação física, repetição e introjeção dos

\footnotetext{
${ }^{194}$ Correio Paulistano, Todos os Esportes, O Homem Negro no Esporte Bandeirante, 24-10-1934, pg.7. disponível em <http://hemerotecadigital.bn.br/acervo-digital/> acesso em 12/11/2014.

195 Idem. Grifo nosso.
} 
movimentos. Pensando como pensaria um jornalista esportivo dos anos 30, e com isso seguindo o raciocínio de Salathiel de Campos, o homem negro seria melhor jogador de futebol porque as qualidades exigidas por este esporte são inatas a ele mais do que a qualquer outra raça. Como no seguinte trecho:

"O homem negro tem todas as qualidades para o futebol. A sua extraordinaria robustez physica, principalmente, tem concorrido para essa victoria no futebol."

Nascendo com essas qualidades, "o negro apprendeu o abe do futebol na varzea"197. Para o autor, a conjuntura estava completa: os espaços da várzea dos rios se abriam para os campos de futebol, ali era permitida a entrada de homens negros, o esporte não era custoso e por isso, apesar de sua "condição econômica", o negro conseguiria praticá-lo, e para tanto tinha todas as qualidades inatas que eram necessárias. Os clubes de várzea e do interior do estado atenderam ao "crescei-vos e multiplicai-vos", mas, no futebol oficial, ainda havia o "preconceito de côr" 198.

É discutindo esse tema que Salathiel de Campos expõe seu conceito de raça e de raça brasileira, e cita, para concordar, algumas de suas referências, como Oliveira Viana e Vicente de Carvalho. Este último diz ser o Brasil a única grande região em que se realizou a fusão de três raças de forma completa. "Somos mestiços", afirma Carvalho, e “é como mestiços que nós estamos constituindo uma grande nação, como mestiços cumpriremos os nossos destinos". ${ }^{199}$ É um discurso que se contrapõe - e isso explicaria o porquê de Salathiel citá-lo tão longamente - ao projeto de branqueamento da sociedade brasileira, com incentivos à imigração branca e uma certa emulação de ares europeus. Ao citar Carvalho, o autor traz para o seu texto alguns dos objetivos do movimento patrianovista - de defesa da pátria e da raça brasileiras, contra a qualquer "imperialismo estrangeiro" - e dos frentenegrinos - por afirmar a negritude da raça brasileira. ${ }^{200}$

\footnotetext{
${ }^{196}$ Correio Paulistano, Todos os Esportes, O Homem Negro no Esporte Bandeirante, 06-10-1934, pg.7. disponível em <http://hemerotecadigital.bn.br/acervo-digital/> acesso em 12/11/2014. 
Logo em seguida, o jornalista militante cita "as opiniões de varios escriptores e jornalistas de nomeada". Listadas a seguir:

Costallat, Gazeta de Notícias:

"Devemos ser conhecidos na Europa tal como somos. Como nossos negros e com tudo o mais".

Artigo 20 da Ação Social Nacionalista:

"É dever combater o preconceito de raças salientando as vantagens resultantes do caldeamento de raças".

Basílio Magalhães, de O Jornal, 13 de maio de 1920:

"Se é de lamentar que a nossa patria mantivesse por mais tempo (...) a escravidão (...) mais ainda é de lamentar que não houvesse surgido aqui, a benefício dos descendentes actuaes dos míseros captivos, a alma sobrehumana de um Bocker Washington $[\text { sic }]^{201}($...)Se á raça affectiva (preta) muito deve eto-etchnicamente a nossa nacionalidade deve-lhe ainda mais economicamente, porque quasi toda a nossa grandeza material, no passado colonial e monarchico, é produto do braço africano."

Conde Affonso Celso, presidente da Ação Social Nacionalista:

"No terreno social o nacionalismo quer de todo extinguir o preconceito de raça ou de côr conferindo ao indio e sobretudo ao africano e ao mestiço o ponto de honra que lhes compete na evolução brasileira".

B. Pereira de Sousa, segundo Armando Prado na Revista Do Brasil, novembro de 1916:

"Sim, veio dalli (da Africa) a civilização brasileira, porque daquella região veio o braço forte do negro, unico que sob este clima então mais inclemente que hoje poderia produzir, como produziu, as riquezas que proporcionaram recursos aos nossos paes para mandarem os seus filhos ás academias e universidades da Europa...".

Arthur Bomilcar, trechos de um artigo publicado no semanário carioca

Gil Blas, n.31, agosto de 1921:

"A unica especie de immigrantes que aqui não veio para depredar as nossas riquezas naturaes, exhaurir as nossas minas, e nos beber lentamente o sangue, foi a immigração preta".

Cita também Assis Chauteaubriand, publicação do Correio da Manhã, n.778, de 1920:

"Quer queiramos quer não o sangue negro deve correr nas veias de todos nós brasileiros".

\footnotetext{
${ }^{201}$ Basílio Magalhães provavelmente se refere a Booker T. Washington, deve ter havido um erro de digitação, trocando o segundo "o" por um " $\mathrm{c}$ ". Booker Washington foi um escritor e educador estadunidense do século XIX. Ele tinha origem afro-americana e, uma vez que alcançou uma posição rara aos negros americanos naquele período, acabou por ser porta-voz dessa população. Dois de seus principais trabalhos são: Up from Slavery e My Larger Life.
} 
Horacio de Carvalho, do Correio Paulistano, mais um artigo de data comemorativa, publicado no 13 de maio de 1895 em Estudos e Impressões:

"Devemos a essa raça toda a affeição de que formos capazes, todas as complascencias nobres, todas as sympathias."

E Salathiel de Campos encerra a rodada de citações dizendo:

"Mas...deixemos os nescios com esse temor immenso de se confessar ou reconhecer herdeiros do sangue negro e prosigamos em nossa tarefa..." 202

Após expor todo o seu arsenal teórico, Salathiel reproduz, quase na íntegra, um perfil de um jogador negro que fora publicado na coletânea Nossos Campeões ${ }^{203}$ - como já citado aqui, escrita e organizada por ele:

" Mais que em qualquer outra região do paiz, São Paulo vinha mantendo no nosso futebol um cégo e tolo preconceito.

Imbuido de inexplicavel sensibilidade, o futebol official pretendia ser uma facção selecta, sem se lembrar que de ha muito se "misturava" abertamente, perdendo por completo a sua qualidade 'academica'.

$(\ldots)$

Por que vedar a entrada em seu seio aos filhos de uma raça que foi o maior factor do seu progresso economico, $e$ concorreu com grande dóse de seu sangue para a formação de um typo mais caracteristico da gente que habita esta parte da America?

Por que fechar as portas aos elementos essencialmente nacionalistas, e abril-as a todos os outros das varias correntes immigratorias, não seleccionadas e, por isso mesmo, capazes de produzir desequilibrios?

É bem verdade que no futebolismo bandeirante militaram alguns elementos escuros, descendentes proximos de negros, mas esses, nume situação quase especial e privilegiada, procuravam esconder essa descendencia materna ou paterna, negra, e tinham a protegel-os o prestigio tradicional de familia.

\footnotetext{
202 Idem

${ }^{203}$ Correio Paulistano, Todos os Esportes, O Homem Negro no Esporte Bandeirante, 06-10-1934, pg.7. disponível em <http://hemerotecadigital.bn.br/acervo-digital/> acesso em 12/11/2014.
} 
Era preciso quebrar esse estado apprehensivo e ridiculo de um preconceito que não poderia existir, racional e conscientemente.

Era preciso que, demonstrando seus meritos pessoaes, apparecessem no nosso futebol official elementos negros vindos da grande massa. "204

O jornalista diz que São Paulo alimentava o preconceito de cor mais do que qualquer parte do país, o que pode ser confirmado por Petrônio Domingues quando ele diz que havia em São Paulo um racismo de outra ordem, "segregacionista e costumeiro" 205. E isso explica a razão pela qual o "futebol official pretendia ser uma facção selecta", fechada mesmo para os "elementos essencialmente nacionalistas", apesar de aberta para os imigrantes. Os negros que conseguiram participar desse futebol o fizeram por estar em uma situação privilegiada, com o prestígio de famílias tradicionais, como o próprio Salathiel de Campos já havia dito em outro momento.

Depois, o autor segue questionando como era possível deixar de fora da sociedade os "filhos de uma raça" que foi o "maior factor do seu progresso econômico" e que contribuiu para formar um "typo mais característico da gente". Reunindo seu nacionalismo patrianovista e sua militância, Salathiel coloca os negros como "elementos essencialmente nacionalistas", para os quais São Paulo fechou as portas, para então "abrilas a todos os outros das varias correntes immigratorias" capazes, ainda segundo Salathiel, de produzir desequilíbrios. É flagrante a valorização da negritude como o mais importante elemento das três raças que formam a raça brasileira, assim como a preocupação com a questão imigratória, a desconfiança com o estrangeiro - bandeiras da Ação Patrianovista Brasileira e da Frente Negra.

Ainda falando sobre raça, Salathiel de Campos conta como jovens discutiam e negavam sua descendência. Quando encontravam estudiosos que "demonstravam terem nas veias de todos indivíduos brasileiros descendentes uma dose de sangue africano", estes tais jovens desconversavam ou se mostravam tolos, “se 'defendem', negam de pés juntos".

\footnotetext{
${ }^{204}$ Correio Paulistano, Todos os Esportes, O Homem Negro no Esporte Bandeirante, 06-10-1934, pg.11, rodapé. disponível em <http://hemerotecadigital.bn.br/acervo-digital/> acesso em 12/11/2014. 205 DOMINGUES, Petrônio. In: FERREIRA, Maria Cláudia. Espaços de sociabilidade e ações anti-racismo no cotidiano das elites negras na cidade de São Paulo: busca por projeção individual e legitimidade de grupo (1900-1940). Revista Mosaico, no 3, ano II, 2010.
} 
"O brasileiro (descendente ou que tenha um lado de descendencia)

é uma especie de sujeito preoccupado em desfazer a sua apparencia physica. Em geral pardo e com todas as caracteristicas das tres raças de seu cruzamento, portugueza-negra-india, vive a blasonar a ausencia em suas veias de pequena dose que seja do sangue negro!... É uma especie de satisfação intima, de descargo da consciencia. $" 206$

Enquanto a negritude era negada e a branquitude exaltada, o terceiro elemento da tríade da suposta "raça brasileira" também era acionado, como explica Wilson Gambeta:

"Com o desaparecimento da ordem escravista, a convivência nas ruas devia ser disciplinada por outros métodos. Mais do que exercer o poder era indispensável parecer poderoso aos olhos do público. Qual era, afinal, a identidade dos verdadeiros comandantes paulistas? A velha moral católica dos senhores de escravos não servia mais. Precisavam criar um passado histórico glorioso que pudesse justificar sua precedência de mando e assim figurar como donos, desde sempre, do lugar. Passaram a exibir brasões, a cultivar genealogias das estirpes do planalto de Piratininga e a identificar ancestrais de sangue indígena $e$ bandeirantes mamelucos. "207

Temos que a branquitude não precisava, como nunca precisou, de uma defesa. Era uma não-raça - quem tem raça são os negros, os indígenas, os brancos são a norma, o padrão. O elemento indígena era acionado como uma justificativa de poder, para assegurar a elite como dona "desde sempre, do lugar", e, além disso, na São Paulo desse período, já não havia mais indígenas que ameaçassem de forma alguma a branquitude. Era a essa altura um elemento apagado, coisa do passado bandeirante, algo que não fazia parte do convívio social. Por isso, era urgente à população negra, a terceira raça da tríade, uma afirmação, um posicionamento firme e imponente. Salathiel de Campos define o seu lado nessa disputa que acontecia ao mesmo tempo na política, na psicologia individual e

\footnotetext{
${ }^{206}$ Correio Paulistano, Todos os Esportes, O Homem Negro no Esporte Bandeirante, 05-10-1934, pg.7, rodapé. disponível em <http://hemerotecadigital.bn.br/acervo-digital/> acesso em 12/11/2014.

${ }^{207}$ GAMBETA, Wilson. A bola rolou: o velódromo paulista e os espetáculos de futebol. São Paulo: SESIEditora, 2015. pag 168
} 
no trato com a memória e a história de São Paulo. Nesse sentido, Salathiel de Campos, segundo ele próprio, saiu em defesa daqueles que queriam ser defendidos.

\subsubsection{A várzea e o futebol amador}

O texto de Salathiel começa em "tempos remotos", quando só havia o "esporte" da caça e a pesca, e "os que assim não se distrahiam" procuravam companheiros para jogar o "nacionalissimo 'truque'[jogo de cartas, o truco]”. Em seguida, o jornalista identifica a demanda por novas atividades no "tempo livre" - um processo que identificamos como a consolidação do capitalismo industrial no Brasil e um avanço da espetacularização da sociedade ${ }^{208}$. Salathiel diz que "S. Paulo ia crescendo em população e actividades, e a população recrescente exigia novos meios de distracção para o descanso dominical."209

A imigração era crescente e "S. Paulo se enchia de gente nova e com outros costumes". As colônias tinham uma vida totalmente à parte, "principalmente os anglosaxões(...) sempre foi vezo do inglez constituir a sua sociedade isolada" e, segundo ele, os alemães não fugiram a essa regra. Sem questionar a elite e seus discursos, Salathiel de Campos reforça o mito de fundação do futebol, a volta de Charles Miller ao Brasil construção da elite paulistana que tentava tomar para si a guarda desse esporte:

\section{"Um inglez, Charles Muller, destacado para desempenhar um cargo de importancia na Mala Real Ingleza (...) e hoje um dos membros mais proeminentes da colonia ingleza, chegou ao Brasil e, amante dos esportes, trouxe consigo uma bola de futebol. "210}

Partindo do mito de fundação, diz que o esporte chamou atenção dos "brasileiros" - uma vez que começou com os “anglo-saxões”. Em primeiro lugar, dos estudantes - que faziam parte dessa mesma elite. A narrativa segue a linha do tempo das fundações de novos clubes como o Internacional, e de seus dissidentes que fundaram o Germânia, liderados pelo alemão Hans Nobiling, o início do futebol no Paulistano, a fundação do Americano, do Palmeiras, entre outros. Em sua exposição dos primeiros anos do esporte

\footnotetext{
${ }^{208}$ Adorno escreveu um texto importantíssimo sobre a questão do "tempo livre", identificado por ele como uma extensão do trabalho, uma vez que serve apenas para recarregar as energias do trabalhador que em seguida serão novamente exauridas. Se o trabalho é reificado, transformado em mercadoria, o mesmo acaba acontecendo com o tempo livre: "o tempo livre é acorrentado ao seu oposto". ADORNO, Theodor. Tempo livre. In: . Indústria cultural e sociedade. São Paulo: Paz e Terra, 2002.

${ }^{209}$ Correio Paulistano, Todos os Esportes, O Homem Negro no Esporte Bandeirante, 03-10-1934, pg.7. disponível em <http://hemerotecadigital.bn.br/acervo-digital/> acesso em 12/11/2014.

210 Idem.
} 
no Brasil, Salathiel de Campos descreve a dinâmica do mais alto escalão da sociedade, cujos membros eram "elementos dos mais representativos, social e moralmente, em nosso Estado".211

Salathiel de Campos não problematizava a posição da elite. Queria, isso sim, que os negros também fizessem parte do grupo. Ao falar da formação elitista do que ele chama "futebol acadêmico", diz que a "a massa popular" começou a apreciá-lo, a "desvendarlhe os predicados emocionantes". E, ao mostrar a elite, de um lado, praticando o futebol como hobby, e a "massa popular", de outro, assistindo e tomando gosto, Salathiel diz que: "O futebol paulista faz-nos lembrar um pouco de sociologia: o caldeamento de raças e o natural desapparecimento de uma, absorvida pela outra" 212

Enquanto fala da "massa popular" que, por enquanto, apenas assiste aos eventos futebolísticos, ele aponta para o fim dessa história: a absorção pela massa do esporte que começou restrito à elite. $\mathrm{O}$ jornalista militante trata desse período como um futebol ainda recém-nascido, contando a história do esporte em metáforas biológicas. Para ele, o futebol nasceu:

"academico e fidalgo(...)Teve uma infancia toda risonha e florida, e muito embora a voluntariedade das crianças ricas, elle esteve sob os olhares severos paternos e dos mestres. Cresceu dentro de uma disciplina, na mais fiel observancia de todos os principios $e$ preceitos de obediencia e cordialidade. Naquelle tempo só jogavam futebol rapazes das escolas superiores, filhos de familias abastadas, rapazes do nosso alto commercio" 213

Apresentados os senhores do futebol oficial, Salathiel fala da disseminação do esporte e do consequente aparecimento dos clubes de várzea, com uma analogia bem ao seu estilo:

"Desenvolveu o mandamento sacro de 'crescei e multiplicae-vos'.

Começou a surgir a varzea." 214

E acrescenta, falando sobre a alcunha (várzea) do futebol não oficial:

\footnotetext{
211 Idem, ibidem.

212 Idem, ibidem.

${ }^{213}$ Idem

${ }^{214}$ Idem, ibidem
} 
“Expressão typica para differençar classes..." "215

“Dahi, as duas grandes correntes no nosso futebol: o 'academico' ou official e o varzeano", eis a oposição construída por Salathiel de Campos. O jornalista começa a detalhar a formação da várzea e só fala do futebol oficial na medida em que o homem negro consegue entrada. Algo natural já que seu objeto de estudo, ou seu protagonista, é o "homem negro" em sua trajetória no "esporte bandeirante".

Começam a surgir clubes fortes e nomes de destaque:

"quando um jogador começava a ser conhecido e falado na várzea, é porque o merecia demais (...) A imprensa apenas se preocupava com os clubes officiaes e seus campeões, que, como era natural, punha toda a sorte de empecilhos ás pretensões dos varzeanos candidatos a nelles ingressar. "216

Salathiel de Campos fala de preconceito, racismo, estatutos de clubes que proibiam pessoas "de côr", e toda sorte de empecilhos. Ao mesmo tempo, fala deste mesmo futebol oficial que se fecha ao homem negro com uma certa admiração, ao menos a respeito da técnica, ao dizer que "não restava, pois, outro remedio aos varzeanos, que continuarem enthusiasticamente por ahi a fóra, a cultivar, aos trancos, o seu futebol, que, diga-se de passagem, era tão bom, quasi como o official”. Agora praticantes do esporte, os brancos pobres e negros que jogavam na varzea eram ainda espectadores do futebol oficial, e se entusiasmaram com os jogos "internacionaes e inter-estaduaes de 1910”, com os quais "as lições dos mestres" foram "observadas e postas em prática, pelos alumnos intelligentes e enthusiásticos".

Em qualquer uma das leituras que façamos, esse aspecto é importante. Analisando sob a perspectiva acadêmica, este fato reforça a tese de que ao negro basta dar treinamento, exemplos morais e técnicos, para que demonstre o seu talento inato, inteligente e entusiástico. Sob a perspectiva da militância, o autor mostra que não há razão para barrar os negros, uma vez que observam, aprendem e põe em prática. Sob a perspectiva da narrativa épica, este é o momento no qual o mestre mostra o caminho para seu pupilo, o herói, que irá sair em sua jornada.

Salathiel diz que, no início, o futebol "não era como hoje [os anos 30], em que virtualmente as duas classes [futebol de varzea e futebol oficial] desappareceram e um nada mais é que o celeiro do outro". A esses negros do futebol de várzea, que aprendem

215 Idem, ibidem
216 Idem, ibidem 
rápido e têm talento inato, bastava que os caminhos para o futebol oficial fossem abertos para que a várzea se tornasse seu "celeiro".

Ao dizer, em seguida, que o "progresso deveria vir um dia, total, insophismavel, e emquanto elle assim não o fosse deveria a varzea, periodicamente, apresentar seus campeões, isoladamente", o jornalista parece condicionar a entrada dos varzeanos no futebol oficial a um progresso técnico, a um aprendizado com "os mestres", de modo que fosse “insophismavel”. É a preparação do herói, por um lado, e a defesa de oportunidades de aprendizado para a população negra, por outro - aspecto muito importante na luta do movimento negro, tanto na época quanto atualmente:
"E, de facto, os varzeanos jogavam bem. Apenas os differençava dos elementos do futebol official o gráo de educação e instrucção. "217

Salathiel de Campos conhecia as razões dessa diferença no grau de educação e instrução. A diminuição dessa distribuição desigual do conhecimento e da informação era largamente debatida em sua atuação na militância do movimento negro. Nessa mesma época de que fala Salathiel, a população negra tinha circulação bastante restrita, totalmente oposta à abertura dos campos do futebol de várzea, como vemos na seguinte denúncia:

\begin{abstract}
"Em 1927, um colaborador do Clarim d' Alvorada reclamou da segregação imposta aos transeuntes negros no Jardim da Luz. Aos negros cabia apenas freqüentar o entorno do jardim, ficando impedidos de se aproximarem do centro onde ocorriam as apresentações da Banda da Força Pública. As moças negras eram ainda alvo de chacotas e vaias, especialmente aquelas que ousavam usar chapéus, marca distintiva de pessoa moderna, adjetivo que não se associava à mulher negra" 218
\end{abstract}

As linhas divisórias estavam traçadas até mesmo no âmbito privado das residências:

\footnotetext{
${ }^{217}$ Esse trecho é interessante também se lembramos do rugby, esporte sobre o qual foi criada uma fama de violência e perigo. Avisos em jornais aconselhavam que não se praticasse rugby, como aponta a pesquisa ainda em andamento de Victor Sá Ramalho Antônio. Ainda que o argumento de Salathiel - de que o futebol teve mais praticantes na medida em que o medo de sua suposta violência acabava - não se comprove, ele revela que havia no futebol, como houve (e há) no rugby, essa má fama entre os não praticantes.

${ }^{218}$ Cf. Clarim d' Alvorada, 15-1-1927; 28-9-1930. In: FERREIRA, Maria Cláudia. Espaços de sociabilidade e ações anti-racismo no cotidiano das elites negras na cidade de São Paulo: busca por projeção individual e legitimidade de grupo (1900-1940). Revista Mosaico, no 3, ano II, 2010.
} 
"Apesar de os negros e brancos residirem no mesmo terreno e 'dividirem parede', a linha de cor era quase indelével: enquanto o negro morava no porão, embaixo, o imigrante italiano morava na residência, em cima." 219

Na cidade que se fecha aos negros, a várzea era um dos poucos espaços abertos. É muito significativo que Salathiel de Campos, no início de sua carreira, tenha saído de revisor para redator justamente para cobrir o futebol de várzea. Conhecedor do assunto, testemunha ocular de parte dessa história, o jornalista fala longamente do futebol varzeano em todo o livro.

Identifica esse fenômeno como um dos motivos da bem sucedida disseminação do futebol: a quantidade de espaços verdes onde era possível jogar futebol já que "Naquelles tempos [anos 10], não se conhecia a febre das construções, como hoje [anos 30]", havia longas várzeas bem perto do centro da cidade e era "facilimo conseguir-se um campo de futebol" ${ }^{220}$. Esse elemento da disseminação do futebol pelas várzeas também foi descrito por Hilário Franco Júnior quando diz que os varzeanos jogavam "sem equipamentos adequados" e "com bolas desgastadas e mesmo improvisadas em terrenos ainda não ocupados pelo processo de urbanização"221.

O livro também apresenta longamente outra especialidade deste autor, um caipira de Piracicaba, o futebol do interior:

"Si isso se verificava na Capital, o interior não poderia fugir ao reflexo. Os grandes centros industriaes e fabris, bem como estudantinos, iniciaram a campanha pró-futebol com grande enthusiasmo. Sorocaba, S. Roque, Campinas, Ribeirão Preto, Mayrink, Piracicaba, Itú, Capivary, Limeira, São Carlos e outras cidades possuiam bons quadros.

(...)

Dado o numero elevado de clubes e bem assim a força technica que possuiam, organizaram seus campeonatos locaes.

\footnotetext{
219 Idem, ibidem.

${ }^{220}$ Correio Paulistano, Todos os Esportes, O Homem Negro no Esporte Bandeirante, 03-10-1934, pg.7. disponível em <http://hemerotecadigital.bn.br/acervo-digital/> acesso em 12/11/2014.

221 FRANCO JR., Hilário. Dança dos Deuses. São Paulo: Cia. das Letras. 2007. Pg. 64.
} 
Foi assim que o futebol conseguiu radicar-se completamente em S. Paulo, dominando todas as camadas... "222

Salathiel aponta as centenas de "clubes modestos que surgiam e desempenhavam papel saliente", muitos deles com vida curta, é verdade, mas vários perduravam e rivalidades começavam a ser construídas, o que imprimia mais emoção aos jogos, "o incentivo para contendas emocionantes". Os clubes fracos se fortaleciam e os fortes brigavam para serem o melhor entre todos. O mais relevante para a nossa análise nessa parte do livro é que Salathiel encarava o futebol do interior como uma extensão da várzea. Uma vez que esses clubes, ainda segundo autor, escalaram jogadores negros e, da mesma forma que a varzea, não participavam do futebol oficial da APEA, parece natural que esta tenha sido a visão do jornalista.

Temos por óbvio que, mesmo com alguns jogadores negros nos quadros de seus times de futebol, havia um racismo atroz no interior do estado, como podemos perceber com o depoimento de Aristídes Barbosa para o livro Frente Negra Brasileira: depoimentos:

“Em Mococa havia um racismo tremendo. Pra se ter uma ideia, não podíamos jogar no time de futebol dos brancos. Eramos sempre deixados de lado, embora nunca dissessem explicitamente a razão. Tivemos então a iniciativa de formar um time de futebol só de pretos. Dessa forma podíamos jogar. "223

Algo identificado por Salathiel de Campos, mas apenas em referência ao "futebol oficial" dos clubes amadores:

\begin{abstract}
"Não se verificava, como annos depois, o facto de se encontrarem sob a mesma bandeira social o chefe de uma grande casa commercial em companhia de um empregado que desempenhasse funcções subalternas, como por exemplo a de carroceiro."224
\end{abstract}

Salathiel de Campos, por ter escrito o livro em 1932 e publicado em 1934, não teve incluída em seu recorte temporal a profissionalização de fato. Ele fala, no máximo,

\footnotetext{
${ }^{222}$ Correio Paulistano, Todos os Esportes, O Homem Negro no Esporte Bandeirante, 04-10-1934, pg.7. disponível em <http://hemerotecadigital.bn.br/acervo-digital/> acesso em 12/11/2014.

${ }^{223}$ BARBOSA, Márcio. Frente Negra Brasileira: depoimentos. São Paulo: Quilombhoje, 1998. Pag.17.

${ }^{224}$ Correio Paulistano, Todos os Esportes, O Homem Negro no Esporte Bandeirante, 04-10-1934, pg.7. disponível em <http://hemerotecadigital.bn.br/acervo-digital/> acesso em 12/11/2014.
} 
do chamado profissionalismo marrom dos anos 20. Ainda que tivesse escrito o livro anos mais tarde, como podemos notar nesse e em outros textos do jornalista, o espaço no qual ele quer ver a entrada dos jogadores negros é o futebol amador.

Em fins de 1932, trabalhando n'A Gazeta, já que o Correio Paulistano, por ser veículo do Partido Republicano Paulista, havia sido fechado pelo governo de Getúlio Vargas, Salathiel de Campos já mostra o amadorismo como coisa do passado:

\section{"A grande questão do momento. O profissionalismo declarado ás portas do nosso futebol - Estudemos o assumpto com meticuloso cuidado necessário - Exemplos frisantes e algumas victimas do amadorismo disfarçado \\ Nos dias que correm, falar em amadorismo no futebol é o mesmo que querer recordar um passado que se vae distanciando nas dobras do tempo. Hoje, é uma mythologia apenas, nos annaes de nosso futebol." 225}

Salathiel continua dizendo que já se vão mais de 17 anos desde que começaram a enfraquecer a "mentalidade que sempre dominou e norteou o futebol brasileiro, notadamente o paulista". Amadorismo, segundo ele, ficou sendo sinônimo de futebol "acadêmico"226. Ele segue elogiando o futebol amador, "não só pelo lado puramente moral de seus cultivadores", mas também pela "compostura dos assistentes e exhibições technicas dos jogadores", um “futebol sciencia, onde o que mais agia era o cérebro"227.

Seu texto critica dirigentes de futebol "imprevidentes", que não "marcharam adeante, acompanhando os passos progressivos do futebol. Estacionaram, diz ele, mas “os problemas do esporte, não". Quando se lembraram de fazer alguma coisa, "viram-se atônitos ante uma muralha alta e de difficil accesso". Para ele, o futebol brasileiro apenas contemplava o avanço de outros países, "onde a politica-interesseira não obliterara a mentalidade dos dirigentes" 228 .

\footnotetext{
${ }^{225}$ A Gazeta, 01/11/1932. disponível em <http://hemerotecadigital.bn.br/acervo-digital/> acesso em 22/08/2015. 226226 Idem.

227 Idem, ibidem.

228 Idem, ibidem.
} 
Segundo Salathiel, o falso amadorismo era "um monstro de mil cabeças". Diz que é tão pernicioso o jogador que recebe dinheiro do clube quanto aquele que não aceita o pagamento mas exige favores. E diz:

\section{"É natural que as tradições de uma praxe (...) se guardam tal qual os usos primitivos as trouxeram para a vida activa de um povo. (...)}

Não podendo guardar tão puro como se iniciara entre nós a pratica do futebol (...) que se estudasse com superior visão, com grande sinceridade todos os problemas decorrentes do esporte bretão nesse passo largo do profissionalismo,"229

$\mathrm{Na}$ perspectiva de Salathiel, "vimos, no meio da maior tristeza, esse desferir continuo de golpes mutiladores da grande obra que construímos nas primeiras décadas do futebol". Ele parece preocupado em remediar o mal do "amadorismo mascarado". "Estamos estupefactos à frente do nosso futebol como o engenheiro que olha para a cidade em ruinas que um tufão destruiu e urge reconstruir. Tudo deverá ser feito de novo. Desde o alicerce" ${ }^{230}$. Sua crítica é que só se aplicavam paliativos, e, segundo ele, "a base para essa opposição é a velha phrase: - Não devemos expor amadores ao vexame de uma profissionalização", e completa "Pundonor hypocrita! O amadorismo já é um mytho".

Depois, traz a relação desse futebol com a várzea, espaço visto por ele com grande carinho e afinidade:

"Como antigamente os collegios eram os celleiros do futebol, hoje, a varzea desempenha esse mister. Mal um pequeno apprende a pontapear uma bola e já é cobiçado por elementos deste ou daquele clube."

Após apontar sua pena à várzea, a colocando como a fonte do futebol da época, diz que nem sempre o jogador tem a "preocupação de jogar, mas é que a simples presença no treino faz ju's a uns cobres, geralmente $5 \$$, para o bonde". Relata, então, que um amigo o levou ao vestiário de treino de um certo clube, quando testemunhou o anúncio de uma

\footnotetext{
${ }^{229}$ Idem, ibidem. Grifos nossos.

230 Idem, ibidem.
} 
tabela de preços para vitória, empate ou derrota. Dai, sua diferenciação: amadores e "amadores", entre aspas.

Salathiel pondera que há aqueles clubes que aderem a este sistema para melhorar tecnicamente seus times, por isso o problema central parece ser a "grande maioria de 'directores' e aggregados ás directorias de clubes que apenas procuram levar jogadores para ganhar por cabeça, e conseguem boas quantias de comissão pela inscripção de jogadores de nomeada ou promissores (...) com a nova mentalidade do 'passe' e sua consequente negociação (...) esse commercio de futebol promette muita cousa!"231.

Pondera, pensando no lado do jogador que "quando (...) é esperto e inteligente, consegue tirar proveito desse regimen de amadorismo disfarçado, estabiliza-se na vida e depois manda ás favas o futebol, porque tem meios de vida". E compara:

"Como a luz seduz e queima as asas multicolores da
borboleta, a fama é uma aureola falaz que ás vezes
oblitera o espirito do campeão e o conduz á ruina. Só
mesmo uma sadia mentalidade de amador ou perfeita
comprehensão do nosso actual futebol pode obrar
prodigiosos para afastar os jogadores desse abysmo,
preservando-lhe o futuro"

Quando "fascina os adeptos pela excellencia da technica (...) a encher de dinheiro as bilheterias (...) passeia principescamente a sua figura popular", mas "quando essa fama perde o seu brilho, a sua estrella começa a empalidecer”. Por fim, enaltece completamente o amadorismo: "O esporte amador e nelle o futebol, é uma escola de civismo. Nelle se empregam todas as qualidades, desde a intelligencia até o cavalheirismo, fazendo do homem um typo temperado de animo para todas as luctas da vida. Ai daquele que não consegue temperar o seu animo e que não tirou do futebol as licções que se lhe apresentaram" 232 .

Aqui, mais um indício para dizer que Salathiel não problematiza a posição da elite, não deseja revolucionar o estado de coisas da sociedade da época. Seu objetivo era que a população negra alcançasse o mesmo posto, numa relação horizontal, compartilhando valores morais e uma alto posição na hierarquia social. Por isso, o futebol no qual os negros deveriam entrar era o amador, não o profissional, já que:

\footnotetext{
231 Idem, ibidem.

232 Idem, ibidem. Grifos nossos.
} 


\section{"O profissionalismo veiu estabelecer um triste desequilibrio em nossos meios futebolisticos ${ }^{, 233}$}

Segundo Leopoldo Sant'Anna ${ }^{234}$, citado por Salathiel de Campos, bastava que um indivíduo de "moral duvidosa" se adestrasse na prática do futebol para que fosse contratado, descoberto por "emissarios solertes" e disputado "a peso de ouro"235. Assim, sabendo que representava um "capital-dinheiro que vale mais que o capital-aptidão"236, tinham certeza que não seriam postos "á margem" e com isso perdia-se o controle sobre a disciplina em campo. No profissionalismo, não havia seleção moral, o que Campos e Sant'Anna valorizam sobremaneira.

Numa das passagens mais interessantes a esse respeito, Salathiel de Campos afirma que "todo o preto era, por índole ou mania, torcedor do Paulistano", Desde os tempos do "do antigo Velodromo". Diz ainda que, mesmo após este clube ter se afastado do futebol, o São Paulo F.C., "seu substituto", continua com "essa sympathia negra, porém mais augmentada agora, por contar com jogadores negros em suas fileiras”. O autor diz que "essa torcida lhe foi um auxilio poderoso, um grande incentivo aos seus jogadores que, verdade seja dita, sempre dispensaram aos pretos suas attenções". Mas, nesse tempo de que fala Salathiel de Campos, o problema ainda estava posto, porque "clube aristocratico que era, de uma grande influência econômica, antes do clube de futebol o Paulistano era um meio social e delle não fazia parte nenhum elemento negro" 237 .

Nesse trecho, vemos um entre tanto indícios de que Salathiel de Campos buscava a integração, ou assimilação, do negro também no meio social, uma convivência com essa "aristocracia", como ele chama. Mas isso não acontecia, e assim essa torcida "era a arma constante com que procuravam sempre desarmar os torcedores negros do grande clube

\footnotetext{
${ }^{233}$ Correio Paulistano, Todos os Esportes, O Homem Negro no Esporte Bandeirante, 5-10-1934, pg.7. disponível em <http://hemerotecadigital.bn.br/acervo-digital/> acesso em 12/11/2014.

${ }^{234}$ SANT'ANA, Leopoldo. Supremacia e Decadencia do Futebol Paulista. São Paulo: 1925.

235 Idem.

${ }^{236} \mathrm{O}$ "capital-aptidão" de Salathiel de Campos pode ser comparado ao conceito de capital de Pierre Bourdie. Nos termos desse sociólogo, além do capital-dinheiro, como também foi citado por Campos, há o capital cultural, o capital social, entre outros. Esses vários tipos de capital podem ser acumulados e utilizados como instrumento de poder nos campos (campo cultural, campo político, campo esportivo). Assim, o capital-aptidão de Salathiel de Campos tem equivalência com o capital-esportivo da teoria do francês Pierre Bourdieu.

${ }^{237}$ Correio Paulistano, Todos os Esportes, O Homem Negro no Esporte Bandeirante, 8-11-1934, pg.7, rodapé. Disponível em <http://hemerotecadigital.bn.br/acervo-digital/> acesso em 12/11/2014.
} 
ou arrefecer-lhes o enthusiasmo", sendo comum, segundo o autor, ouvir comentários como:

“ 'Não sei porque esses pretos torcem tanto para o Paulistano.

Clube de ricos e fidalgotes, elle nunca consentiu que um preto pisasse a sua séde!'

'São uns tolos esses negros. Torcem tanto para o Paulistano, que afinal nunca lhes deu confiança!'

'Si esses homens tivesse um pouco mais de raciocinio, não torceriam para o Paulistano. Elle nunca acceitou negro em seu time e nem em seu quadro social!',"238

Mesmo assim a "negrada continuou na sua torcida enthusiastica, com pequena deserção"239 . Dada essa proximidade e a questão da entrada ou não de negros neste clube que é a máxima representação da sociabilidade da elite econômica e política da época, o jornalista cita "uma palestra da qual participavam alguns rapazes do Paulistano" - Dr. Manuel Carlos Aranha, Fernão Salles, Mario Macedo, e outros. Quando tocaram nesse assunto, a resposta foi a seguinte:

"Ha nisso uma verdade e uma injustiça. De facto, o Paulistano não tem em suas fileiras um jogador reconhecidamente preto. Mas já o teve. Somos ali, não sómente um clube de esportes si não tambem um clube de representação social e delle faz parte o que S. Paulo tem de mais fino.

Ora, desde que um homem negro á altura moral, social, economica e intellectual, pertença á nossa sociedade e queira participar do Paulistano não lhe vedaremos a entrada. Vê -se, pois, que não ha razão para tanta queixa. Já tivemos rapazes de epiderme bem escura e teremos desde que seja um rapaz do escol social.

E no quadro de jogadores, temos alguns nem muito claros. Aqui costumamos seleccionar elementos, unicamente."

Salathiel de Campos diz ter achado nessa resposta alguma razão. E, de fato, o argumento da estatura "moral, social, econômica e intellectual" é corroborado pelo

\footnotetext{
238 Idem.

239 Idem, ibidem.
} 
jornalista, principalmente o aspecto moral. O que vemos é uma barreira velada (não tão velada assim) aos negros. Qual a chance de, na primeira metade do século XX, pessoas negras terem estatura econômica o suficiente para entrar no Paulistano? Salathiel de Campos era um jornalista de destaque, que publicava seus livros, trabalhava em mais de um veículo mas, ainda assim, não chegaria nem perto de ter dinheiro o suficiente para poder ser um membro do clube social.

Seja como for, como o argumento da militância de Salathiel de Campos era que, no curto prazo, os jogadores varzeanos que tivessem destaque fossem chamados para jogar nos times do futebol oficial, a quem podiam oferecer seu capital esportivo (ou capital futebolístico, ou capital-aptidão nas palavras de Campos) e, no longo prazo, que a população negra alcançasse a suposta estatura "moral, social, econômica e intellectual" para entrar também nos clubes sociais - ou seja, que recebesse em troca um capital social. Levando isso em conta, faz sentido que ele apoiasse esses argumentos da elite paulistana.

\subsection{O "Rosário de glórias"}

Se o estatuto dos clubes da Primeira Divisão vetava a entrada dos negros no futebol oficial, a Segunda Divisão se abriu aos poucos, admitindo alguns atletas negros. Este é o primeiro estágio da jornada vitoriosa do herói, o início da síntese, ou a identificação dos aliados de um movimento social, a depender de qual leitura possível desse texto for escolhida. ${ }^{240}$

“O povo clamava as proezas de jogadores negros". Segundo o autor, esse fato era um dos motores que levavam os dirigentes a "romper com o preconceito". Salathiel considera a entrada de negros no futebol como um rompimento dessa ordem, mas entendemos esse fato como um preconceito velado, uma "tolerância útil", uma vez que havia bons jogadores negros - assim como brancos pobres - que poderiam servir ao espetáculo futebolístico. Não há integração, não no sentido que Salathiel de Campos pretendia. E ao longo de sua carreira ele perceberia isso.

Encontrados no futebol do interior, da Segunda Divisão ou, como já há muito tempo, das várzeas, os atletas negros começavam a ser chamados aos clubes da primeira divisão. Salathiel de Campos cita o exemplo do Minas Geraes, que retirou de seu estatuto

\footnotetext{
${ }^{240}$ Correio Paulistano, Todos os Esportes, O Homem Negro no Esporte Bandeirante, 07-10-1934, pg.7, rodapé. Disponível em <http://hemerotecadigital.bn.br/acervo-digital/> acesso em 12/11/2014.
} 
a exigência "não ser de côr" ${ }^{241}$. Ao fazê-lo, teve excelente retorno pelos pés de Petronilho, jogador que viria a ser o primeiro "reconhecidamente negro"242 a jogar na Seleção Paulista.

Segundo o autor, a maioria dos clubes, que não haviam ainda incluído elementos negros, ficou esperando os resultados daqueles que o fizeram: Mackenzie, Internacional e Minas Gerais. Os resultados, de início, não foram bons, o que o jornalista atribui ao "natural acanhamento peculiar á raça" - visto aqui não como um defeito congênito dos negros, mas como uma consequência do isolamento social e do racismo exercido pelos brancos desses clubes, o que acuava os atletas negros que chegavam.

De qualquer forma, se, para os paredros, a entrada de negros no futebol poderia significar um acúmulo de capital futebolístico, ainda mais levando-se em conta um contexto de profissionalização, para a população negra isso significava uma ampliação na representatividade - ou pelo menos uma expectativa de receber um capital social. Um fator entre muitos na luta por integração ou, para usar o termo de Leo Spitzer, assimilação $^{243}$ - mas com interferência limitada. Concordando com Salathiel de Campos quando ele diz que os "ídolos da multidão são sempre observados e immitados em todas as suas ações", podemos entender ainda melhor a importância dessa representatividade quando ele cita meninos que tentavam imitar dribles enquanto diziam ser aqueles ídolos que acompanhavam nos campos de futebol.

Gradin, um atleta negro da seleção uruguaia, jogou nos gramados brasileiros durante o Sul-Americano de 1919. A fama desse jogador já era grande, mas os brasileiros ainda não o tinham visto jogar. Após sua apresentação no certame, Salathiel diz que o "appellido ficou á espera de algum campeão em miniatura" ${ }^{244}$. E realmente houve: "Qualquer pretinho que se mostrasse esperto nas fintas e firme nos chutes era chrismado com o nome do celebrado campeão uruguayo" 245 .

\footnotetext{
${ }^{241}$ Correio Paulistano, Todos os Esportes, O Homem Negro no Esporte Bandeirante, 09-10-1934, pg.7, rodapé. Disponível em <http://hemerotecadigital.bn.br/acervo-digital/> acesso em 12/11/2014.

${ }^{242}$ Correio Paulistano, Todos os Esportes, O Homem Negro no Esporte Bandeirante, 11-10-1934, pg.10, rodapé. Disponível em <http://hemerotecadigital.bn.br/acervo-digital/> acesso em 12/11/2014.

${ }^{243}$ SPITZER, Leo. Vidas de Entremeio: assimilação e marginalização na Áustria, no Brasil e na África Ocidental, 1780-I1945. Tradução, Vera Ribeiro, Rio de Janeiro, EdUERJ. 2001.

${ }^{244}$ Correio Paulistano, Todos os Esportes, O Homem Negro no Esporte Bandeirante, 16-11-1934, pg.7, rodapé. Disponível em <http://hemerotecadigital.bn.br/acervo-digital/> acesso em 12/11/2014. 245 Idem
} 
Porém, como largamente discutido atualmente, a representatividade é muito limitada. Não é possível entendê-la como uma ferramenta para atenuar o racismo. Mantendo o mesmo exemplo, um técnico de um time paulista teria dito sobre Gradin:

$$
\begin{aligned}
& \text { "É um campeão authentico. O mais completo meia- } \\
& \text { esquerda que tenho visto actuar. É feio. Mas tem tanto de } \\
& \text { jogo como o tem de fealdade." } 246
\end{aligned}
$$

Tal é o argumento do racista: o negro pode até ser bom de futebol, mas continua sendo considerado feio. A presença de pessoas negras em todo e qualquer espaço deve acontecer simplesmente porque essas pessoas existem, não para que um ou outro negro "represente" os outros todos. Esse é o limite da representatividade: por um lado, mostra publicamente que há possibilidade de uma pessoa negra atuar em certo espaço (algo que deveria ser óbvio), por outro, não desconstrói nenhum conceito estabelecido, não leva a nenhuma ruptura estrutural, nem serve, em si mesma, como meio de inclusão.

A mesma representatividade (limitada) acabou sendo alcançada por Petronilho, Matheus Marcondes e Tatú, o "nome de guerra com que Altino Marcondes passeou pelos campos nacionaes a sua figura athletica de campeão consumado, fazendo delirar multidões electrizadas" 247 . Uma lista de heróis negros dessa narrativa vitoriosa, no que Salathiel de Campos chama: Rosário de glórias.

Tatú, segundo Salathiel, era o "prototypo do esportista”, não era tão ilustrado, mas "era de boa educação e apreciavel instrução"248. Campeão paulista, brasileiro, carioca, sul-americano, nasceu em Taubaté e jogou pelo clube dessa cidade, pelo qual foi campeão do interior. Foi o que mais se destacou entre "os homens de côr" 249.

Tatú e seu irmão, Matheus Marcondes, segundo a narrativa de Salathiel de Campos, eram lendas da várzea. Mostravam habilidade durante o jogo e, com saltos mortais, comemoravam seus gols. Em uma ocasião, num jogo entre República e Mackenzinho, após o gol da vitória nos minutos finais do jogo, a torcida invadiu o campo para abraçar Tatú.

Outro grande herói dessa narrativa, ou outro grande objeto de estudo de Salathiel, é Petronilho de Brito. Para alguns, o inventor da "bicicleta", jogada em que o atleta gira

\footnotetext{
246 Idem ibidem.

247 Idem, ibidem.

${ }^{248}$ Novamente a importância da educação, Salathiel traz a instrução para sua análise frequentemente, tanto sua presença nos exemplos ilustres da elite quanto sua falta entre os pobres.

${ }^{249}$ Correio Paulistano, Todos os Esportes, O Homem Negro no Esporte Bandeirante, 16-11-1934, pg.7, rodapé. Disponível em <http://hemerotecadigital.bn.br/acervo-digital/> acesso em 12/11/2014.
} 
as pernas no ar, como se pedalasse, com as costas viradas para o chão, e chuta a bola no final do movimento. Essa jogada é também atribuída a Leônidas da Silva, outro dos craques negros dessa época. Outros dizem, ainda, que ela fora inventada por Ramón Unzaga Asla, espanhol naturalizado chileno. Petro é irmão do conhecido Waldemar de Brito, que, além de ter sido um atacante importante na história do futebol paulista, descobriria mais tarde, em Bauru, nada mais nada menos que Edson Arantes do Nascimento, o Pelé, e seria o responsável por levá-lo ao Santos Futebol Clube, então bicampeão paulista.

De volta ao outro irmão, o futebol de Petronilho recebeu de Salathiel de Campos uma descrição empolgada e detalhada: rápido, desconcertante, bola sob controle, com infiltração na defesa, movimentos de malabarista, cheios de floreios, rico de improvisos, fintas rápidas, chutes fortes. $\mathrm{O}$ "mulatinho se firmara no controle da bola. Commandava bem o ataque, e começou a pôr em pratica um jogo excellente de passes, fintas e chutes" era tudo "improvisado, acção momentânea (...) são jogadas de boquiabir" que "emocionavam as multidões", fintas rápidas que "emocionava as multidões" 250 . E não para por ai, uma vez que "secundavam a acção de Petro, o jogo desconcertante de Carrapicho, a acção rapida e intelligente de Bisoca, na extrema direita, e o jogo firme de Giby, na zaga. Eram elementos de grande destaque" ${ }^{251}$.

Eis a descrição de um dos elementos da forma-representação imaginada por Salathiel de Campos, baseada toda ela no futebol dos negros da década de 30 . O conceito de forma-representação foi trabalho por Luiz Henrique de Toledo em Lógicas do Futebol $^{252}$ :

“Forma-representação é uma espécie de síntese analítica possível
composta por três naturezas do jogo, a saber, as regras, as formas
de jogo - esquemas táticos - e representações sobre o futebol
condensadas nas chamadas escolas: arte, força etc. Seriam
variadas técnicas corporais, discursivas e tecnológicas à
disposição para embasar e experenciar o futebol. O futebol nos

\footnotetext{
${ }^{250}$ Correio Paulistano, Todos os Esportes, O Homem Negro no Esporte Bandeirante, 10-10-1934, pg.8, rodapé. Disponível em <http://hemerotecadigital.bn.br/acervo-digital/> acesso em 12/11/2014.

${ }^{251}$ Correio Paulistano, Todos os Esportes, O Homem Negro no Esporte Bandeirante, 10-10-1934, pg.8, rodapé. Disponível em <http://hemerotecadigital.bn.br/acervo-digital/> acesso em 12/11/2014. 252 TOLEDO, Luiz Henrique de. Lógicas no Futebol. São Paulo: Hucitec/Fapesp, 2002.
} 


\section{chega e nos emociona por intermédio dessas formas- representações. "253}

Alguns anos antes, em 1929, já se falava no jornal O Estado de São Paulo, sobre as particularidades da "Escola brasileira de futebol", em oposição às "regras adoptadas pelos inglezes" 254 . A inglesa, dizia o texto, subia com todos ao ataque para tentar fazer um gol, enquanto a escola brasileira contava com "dois ou tres bons jogadores" que "façam com a bola uma escapada que, pela sua fulminante rapidez e por ser, ainda, absolutamente inesperada, desoriente e perturbe toda a defesa inimiga" ${ }^{255}$. Não fazíamos mais o "jogo de conjunto" dos ingleses, fazíamos um jogo "com tal ímpeto, enthusiasmo, tamanho, que os adversários quasi não tem tempo (...) de reagir" e podíamos fazê-lo por “dispor de certas qualidades technicas que possuímos desenvolvidas em alto grau"256.

São pontos levantados também por Salathiel de Campos: a velocidade, o entusiasmo, o improviso inesperado, a técnica refinada. Temos ai, com o texto do jornal O Estado de São Paulo (1929), e o de Salathiel de Campos (1932, publicado em 1934) o princípio básico e uma das referências daquilo que seria chamado de Futebol arte no Brasil das décadas seguintes. Esse é um momento importante porque, no início da prática do futebol no país, os filhos da elite emulavam quase completamente o futebol inglês. Os manuais de futebol, como o de Mário Cardim, eram baseados nos dos britânicos. No momento de que falamos, já é possível identificar o que seria o "futebol brasileiro", ou seja, a criação, ou constatação, de uma forma-representação própria.

Mais tarde, em 1938, Gilberto Freyre publicaria o texto Football Mulato ${ }^{257}$, no Diário de Pernambuco, por ocasião do belo desempenho da seleção brasileira na Copa do Mundo da França. O sociólogo diria que, por algum tempo, a escolha dos jogadores brasileiros não tinha "nada de pretos nem de mulatos", mas que essa escolha "antibrasileira" deixou de ser feita. Só então, nosso futebol passou a ter um estilo próprio:

"O nosso estylo de jogar foot-ball me parece contrastar com o dos europeus por um conjunto de qualidades de surpresa de

\footnotetext{
253 Luiz Henrique de Toledo em entrevista para o portal Ludopédio, disponível em $<$ http://www.ludopedio.com.br/entrevistas/luiz-henrique-de-toledo-parte-2/>. Acesso em 05/01/2016. ${ }^{254}$ O Estado de São Paulo, Caderno de Esportes, Um Erro de Orientação. 14/08/1929, pag 12, e 15/08/1929, pag 10.

255 Idem.

${ }^{256}$ Idem, ibidem.

${ }^{257}$ FREYRE, Gilberto. Foot-ball mulato. Diário de Pernambuco. Recife, 1938.
} 
manhã, de assistir, de ligeireza e ao mesmo tempo de espontaneidade individual

(...)

Os nossos passes, os nossos pitu's, os nossos despistamentos, os nossos floreios com a bola, e alguma coisa de dansa e de capoeiragem que marca o estylo brasileiro de jogar foot-ball, que arredonda e adoça o jogo inventado pelos inglezes e por elles e por outros europeus jogado tão angulosamente, tudo isso parece exprimir de modo interessantíssimo para os psychologos e os sociólogos o mulatismo flamboyant e ao mesmo tempo malandro que está hoje em tudo que é affirmação verdadeira do Brasil. "258

Não sabemos se Salathiel de Campos leu esse texto em algum momento, mas certamente ele concordaria, como já vimos. Na década seguinte, mais um autor somaria suas impressões a esse suposto estilo brasileiro: Mário Filho com O Negro no Futebol Brasileiro (1 $1^{\mathrm{a}}$ ed. 1947, $2^{\mathrm{a}}$ ed. 1964). Um irmão mais novo do livro de Salathiel de Campos, que se voltava apenas a São Paulo, ao contrário do outro, que se pretendia nacional apesar de focado na história do Rio de Janeiro. Quem fez o Prefácio do livro de Mário Filho foi justamente Gilberto Freyre, o outro dos dois mais reconhecidos autores do "estilo brasileiro", ou da sistematização do que seria essa forma-representação. Mário Filho exalta especialmente as figuras de Domingos da Guia, Leônidas da Silva e, depois, de Pelé e Garrincha - que tinha descendência indígena - como os símbolos da história vitoriosa do negro no futebol brasileiro.

Ainda hoje, o discurso sobre esse pretenso estilo está associado, de certa maneira, aos atletas negros, como fala Hilário Franco Júnior:
"o samba, com seus movimentos livres, suas gingas e seu ritmo acelerado, corresponde o futebol brasileiro de muita improvisação e dribles. Às várias danças tribais dos africanos, muito atléticas e plásticas, corresponde o futebol feito de imaginação e força que as nações negras, apesar de grande diversificação, praticam. "259

\footnotetext{
258 Idem.

${ }^{259}$ FRANCO JR., Hilário. Dança dos Deuses: futebol, sociedade, cultura. São Paulo: Companhia das Letras, 2007. Pag. 226.
} 
Na época em que Salathiel de Campos escreve, não existiam ainda os textos de Freyre e Mario Filho, mas o paulista já elenca as mesmas características na sua narrativa, apresentando-as como inatas do negro. Essa era a habilidade do herói da epopeia, o argumento de tese para seu trabalho, a principal bandeira para sua militância.

Já temos até agora todos os elementos apresentados por Salathiel para explicar a vitória do homem negro no futebol bandeirante: o futebol é um esporte praticado com qualidades inatas; o negro com sua "robustez physica" era portador dessas qualidades; com elas, praticava uma futebol diferente, particular, atrativo e emocionante. No início da construção dessa forma-representação, o atleta negro era, para Salathiel de Campos (ainda que ele não trabalhasse com esse conceito) o seu principal e mais importante agente.

Com essa forma-representação executada, essencialmente, pelos atletas negros, ideia construída no capítulo "A primeira estréa auspiciosa e o rosário de glorias"260, temos as bases que justificam a presença desses atletas no mais alto escalação do futebol oficial. O que significa, acima de tudo, ter negros não só como jogadores de futebol mas como representantes do estado de São Paulo. Mais importante do que jogar por um clube que tolerava os atletas negros era representar o estado dos bandeirantes. Sobre Petronilho, o símbolo máximo dessa forma-representação, Salathiel disse:

"Era a primeira vez que um jogador reconhecidamente negro integrava a selecção de S. Paulo...

A 'estrella' de Petro começava a brilhar com raro fulgor. De então para cá fez parte da selecção official em todos os campeonatos brasileiros" 261

Como dissemos, o autor saíra em defesa daqueles que queriam e precisavam ser defendidos. Lembrando disso, é interessante notar que o autor diz ser Petro o primeiro jogador "reconhecidamente negro" a integrar a seleção paulista. Reconhecidamente porque havia aqueles "que não o quiseram ser". Era, por exemplo, o caso de Friedenreich. E é sintomático o fato de que o jornalista fala em seu livro do Sul-Americano de 1919 sem citar, nem ao menos de passagem, o desempenho de Friedenreich e seu gol do título na final. Também, como veremos mais adiante, é interessante que nas partidas da Taça

\footnotetext{
${ }^{260}$ Correio Paulistano, Todos os Esportes, O Homem Negro no Esporte Bandeirante, 09-10-1934, pg.7. disponível em <http://hemerotecadigital.bn.br/acervo-digital/> acesso em 12/11/2014.

${ }^{261}$ Correio Paulistano, Todos os Esportes, O Homem Negro no Esporte Bandeirante, 10-10-1934, pg.7. disponível em <http://hemerotecadigital.bn.br/acervo-digital/> acesso em 12/11/2014.
} 
Princesa Isabel, que colocava em disputa um time de brancos contra um time de negros, Friedenreich tenha jogado pelos brancos.

Mesmo com as conquistas - a vitória na luta por um lugar no futebol oficial local e na seleção paulista - o negro segue desvalorizado, da mesma forma que, segundo o próprio Salathiel de Campos, a história brasileira e paulista o desvaloriza. Ainda que exemplo máximo de uma forma-representação que então começa a ser constatada, na visão do autor, São Paulo se orgulha de suas glórias sem reconhecer os sustentáculos de seu progresso, a população negra:

“A epopéa lendaria das Monções, as arrancadas maravilhosas das 'bandeiras', o oceano verde dos cafesaes, que domina milhares de kilometros quadrados e os arranha-céos que orgulham a todo um povo, são fastos que se entrelaçam entre si através dos seculos, mas cujo élo forte e decisivo foi o braço herculeo do negro, derramando o seu suor, sangrando as suas feridas e cahindo exhausto ao peso da tarefa immensa. "262

O mesmo acontece no futebol. Após toda essa trajetória:

"A despeito de serem olhados com mais sympathias, os homens negros, ainda ha, nos nossos meios esportivos, um certo preconceito racial. "263

Ao que acrescenta o grave indício de uma integração bastante limitada:

"Os jogadores, esses têm melhor acção no seio dos clubes e mesmo entre a torcida, mas os esportistas não militantes nem sempre podem entrar para os corpos sociaes dos clubes. "264

É o caso de Alfredo Gomes, que disputava provas de corrida atletismo, "preferindo as de 1500 metros, 5 mil e ás vezes 10.000 metros"265, que fora convidado por Antônio Pardo Júnior, presidente do Paulistano e um dos exemplos mais clássicos de um membro da elite paulistana da época, a se inscrever no clube do Jardim América. Era uma oportunidade para a inclusão, ou assimilação, pretendida por Salathiel de Campos: negros como atletas de clubes de elite, e frequentadores dos “corpos sociaes". Como um

\footnotetext{
262 Correio Paulistano, Todos os Esportes, O Homem Negro no Esporte Bandeirante, 03-11-1934, pg.7. Disponível em <http://hemerotecadigital.bn.br/acervo-digital/> acesso em 12/11/2014.Grifos nossos.

${ }^{263}$ Correio Paulistano, Todos os Esportes, O Homem Negro no Esporte Bandeirante, 09-11-1934, pg.7. Disponível em <http://hemerotecadigital.bn.br/acervo-digital/> acesso em 12/11/2014. 264 Idem.

${ }^{265}$ Correio Paulistano, Todos os Esportes, O Homem Negro no Esporte Bandeirante, 24-10-1934, pg.7. Disponível em <http://hemerotecadigital.bn.br/acervo-digital/> acesso em 12/11/2014.
} 
esportista do Paulistano, Gomes disputou as Olimpíadas de Paris, em 1924, e teve excelente desempenho. Porém:

"Rapaz modesto, acanhado e de condições humildes, Alfredo Gomes, embora o carinho que ali recebeu, notou que não estava á altura social do grande clube e resolveu retornar ao seu velho Esperia, que o acolheu com a mesma consideração de outros tempos. "266

E seria também esse o caso, de uma forma ou de outra, de Petronilho, Giby, Bisoca, Tatú, e outros tantos. Este último, como conta Salathiel de Campos, foi esquecido pelos clubes nos quais atuou após se aposentar. Doente e debilitado, não teve ajuda, mesmo depois de ter deixado vitórias e glórias por onde passou. Segundo Salathiel, foi "duplamente victima: da tuberculose e do esquecimento do clube para o qual dera o melhor de seus esforços"267.

Mesmo quando tentaram organizar um jogo para que a renda fosse destinada a ajudar Tatú, buscaram tirar disso benefícios financeiros:

"Certa vez, quando se pensou em um festival beneficente, clubes que tinham a quasi obrigação de ajudal-o puzeram-lhe empecilhos á ultima hora, e alguns paredros quizeram ganhar comissão desse jogo! "268

O Rosário de glórias foi importante, demonstrou qualidades dos jogadores negros que, antes, eram questionadas. Levou atletas negros à seleção paulista e fez o futebol do estado ser vitorioso - como vimos com mais detalhes no Capítulo 1. Mas fora limitado, estava restrito ainda às quatro linhas dos campos de futebol.

\subsubsection{A guerra simbólica: brancos contra negros}

Havia uma tradição das associações “de homens de cor”, como se dizia na época, de comemorarem o dia 13 de maio. A abolição tinha ainda um significado muito grande para a população negra. Desde 1915, apareceu nessas comemorações um outro elemento: as partidas de futebol entre times de negros contra times de brancos. Geralmente, como

\footnotetext{
266 Idem.

${ }^{267}$ Correio Paulistano, Todos os Esportes, O Homem Negro no Esporte Bandeirante. 21/11/1934. Pag 7, rodapé. Disponível em <http://hemerotecadigital.bn.br/acervo-digital/> acesso em 12/11/2014. 268 Idem.
} 
aconteceria mais tarde na época de Salathiel de Campos, os participantes faziam parte também de diferentes associações negras.

Algo diferente foi quando a organização partiu dos aristocráticos membros da Liga dos Amadores de Futebol, ainda recém criada, com apenas um ano de existência. Como disse Salathiel de Campos:

"Quando a LAF noticiou officialmente a realização dos jogos entre os dois seleccionados compostos cada um de homens brancos e pretos, o nosso mundo esportivo por elles se apaixonou e não foi sem grande impaciencia que esperou pela luta.

$(\ldots)$

O jogo, que foi um dos mais bellos e sensacionaes até hoje presenciados, esteve bastante equilibrado e cheio de lances emocionantes.

A torcida foi phantastica, principalmente a favor dos homens de côr, não deixando contudo, de seguir as regras de bôa educação. "269

Sobre o apoio de Salathiel de Campos ao amadorismo, seu apreço pela moral, cavalheirismo e educação da elite, convém lembrar que foi a LAF a dar, segundo ele, espaço aos primeiros "elementos de cor" no futebol. Foram também os amadores desta liga que organizaram a Taça Princesa Isabel. A primeira dessas disputas, como descritas por Salathiel de Campos, foi:

“...instituida pela LAF em 1927, pára ser disputada no dia em que se commemora a grande data brasileira de 13 de Maio. O presidente interino do Estado naquelle anno em questão, $d r$. Dino Bueno, offereceu a rica taça "Princeza Isabel", que ficaria de posse do quadro que por tres annos consecutivos vencesse o seu antagonista. $" 270$

Além de valer uma pesquisa apenas para esse tema, a Taça Princesa Isabel faz parte deste capítulo porque, com razão, Salathiel de Campos dedicou boa parte de seu

\footnotetext{
${ }^{269}$ Correio Paulistano, Todos os Esportes, O Homem Negro no Esporte Bandeirante. 21/11/1934. Pag 7, rodapé. Disponível em <http://hemerotecadigital.bn.br/acervo-digital/> acesso em 12/11/2014. ${ }^{270}$ Correio Paulistano, Todos os Esportes, O Homem Negro no Esporte Bandeirante. 24/11/1934. Pag 7, rodapé. Disponível em <http://hemerotecadigital.bn.br/acervo-digital/> acesso em 12/11/2014.
} 
livro aos resultados do time dos jogadores negros nesses jogos ${ }^{271}$. Houve três edições organizadas pela LAF, em 1927, 1928 e 1929, sendo que neste último ano foi também realizado - com organização do Clube Atlético Brasil e Amea - um jogo da seleção de jogadores negros contra a seleção (oficial) do Rio de Janeiro. Em 1930 e 1931, duas novas edições do jogo Brancos versus Negros foram realizadas, também com organização do C.A. Brasil. Ainda em 1931, um novo jogo contra os cariocas foi realizado (organização do C.A. Brasil e do C.A. Cordovil), mas dessa vez contra um time também formado apenas por jogadores negros. Em 1932, fora da data comemorativa do 13 de maio - em um 25 de maio - este evento foi organizado pela Frente Negra Brasileira.

Não há exemplo mais claro do que esse para aquilo que Roberto Da Matta chama de dramatização social ${ }^{272}$. Para este autor, o ritual e o drama são o meio pelo qual dada população conta a sua história e, para compreender o futebol, é preciso extrapolar seu caráter funcional e alcançar seu caráter social e político, trazendo à tona as diversas tensões sociais que, em campo, são dramatizadas. Da Matta defende que o futebol é um meio privilegiado para observar os problemas mais significativos da sociedade brasileira, justamente por meio dessa dramatização.

“Os dramas servem como indicadores de normas, relações e instituições nas suas operações concretas e em processos sociais. Um dos pressupostos básicos da idéia de drama social é que uma sociedade sempre se reproduz a si mesma em quaisquer domínios sociais que institui em seu meio. Assim, as dramatizações da esfera econômica se traduzem no plano político, religioso e até mesmo na culinária, conforme a demonstraçã de Claude Lévi-Strauss. O futebol praticado, vivido e teorizado no Brasil seria um modo específico - entre outros - pelo qual a nossa sociedade fala, apresenta-se, revelase, exibe-se, deixando-se descobrir. "273

\footnotetext{
271 Para informações mais detalhadas, consultar o anexo no fim deste trabalho. Devo agradecer imensamente a Denaldo Alchorne de Souza por ter me levado todas essas informações e as fichas dos jogos, além de outras tantas contribuições já citadas aqui, no dia da defesa dessa dissertação. Este trabalho deve muito a ele em vários sentidos, mas principalmente no que diz respeito à riqueza e correção das informações.

272 DA MATTA, Roberto. O ópio do povo x drama de justiça social. Novos Estudos Cebrap, São Paulo, v. 1,4 , p. 54-60, nov. 82

273 idem
} 
Uma taça chamada Princesa Isabel - uma branca nobre a quem foi atribuído o mérito de pôr fim à escravidão, apagando da história a luta dos próprios negros - criada por certa elite paulista - que tentava apagar seu passado rural e escravista, favorecendo uma saída conciliatória e silenciadora - disputada por um time só de negros, e outro, só de brancos ${ }^{274}$, em jogos violentos - como a maioria, senão todos, daquela época, como o próprio Salathiel de Campos aponta diversas vezes, mas, ainda assim, uma violência entre times racialmente divididos -, e nos quais os negros superam os brancos repetidamente, apesar da interferência dos árbitros.

Em um período de afirmação racial, que se opunha a ideias eugenistas do início do século e ao racismo descarado dos brancos, os negros venceram dois dos três primeiros jogos (organizados pela LAF) e só não ganharam também o último por uma interferência do árbitro, que fez o jogo terminar empatado. Aqueles jogadores mostraram as qualidades que Salathiel de Campos afirmava inatas à raça. Todos os elementos parecem ter sido cuidadosamente construídos para dramatizar a questão racial brasileira por meio do futebol. Há poucas dramatizações mais completas que essa.

Estes jogos, em diversas formações, com variados organizadores e com constituições diversas ao longo do tempo, é disputado até hoje na várzea paulistana. Da mesma forma, sobrevive o preconceito e as linhas que separam brancos e negros na sociedade brasileira. Podemos entender esses jogos como uma dramatização de um conflito latente da sociedade paulistana nos anos 20 e 30. Se a elite paulistana - até com os próprios jogos de 13 de maio - buscava uma conciliação de raças, um apaziguamento da tensão pós-abolição, essas partidas podem ser consideradas a representação de uma guerra que não aconteceu de fato, uma guerra simbólica disputada com uniformes e chuteiras ao invés de fardas e coturnos. É o futebol como guerra simbólica, como explicou Hilário Franco Júnior em Dança dos Deuses ${ }^{275}$.

A primeira edição (como já foi dito, disputada em 1927) foi anunciada pelo Estado de São Paulo como "A commemoração da Lei Áurea"276. Nessa primeira partida, os negros vencem e além disso, segundo Salathiel de Campos, conquistam a simpatia do povo que assistia. Por outras razões, mas também por ter organizado esse evento e dado

\footnotetext{
${ }^{274}$ Friedenreich, também de forma bastante representativa, quando jogou, o fez pelo time dos brancos. ${ }^{275}$ FRANCO JR., Hilário. Dança dos Deuses: futebol, sociedade, cultura. São Paulo: Companhia das Letras, 2007. Pag. 235. 116 Correio Paulistano, Todos os Esportes, O Homem Negro no Esporte Bandeirante, 21-11-1934, pg.7. disponível em <http://hemerotecadigital.bn.br/acervo-digital/> acesso em 12/11/2014.
} 
aos negros a oportunidade de se exibir e conquistar a torcida, na visão de Salathiel de Campos a LAF era uma aliada. Na APEA, dizia ele, "ainda perduravam resquícios da velha mentalidade", havia "uma resistencia passiva, silenciosa, retrahida". Na LAF, o jornalista dizia que havia prestigio ao jogador "de côr", os progressos eram mais notáveis, havia uma "mentalidade" que reconhecia os atletas negros "fazendo justiça aos seus meritos". E ainda acrescentava que a iniciativa da LAF era uma "visão sadia de patriotismo". 277

Os negros, nesse momento, gozavam de grande simpatia do público de forma geral - $80 \%$ torcia pelos negros, disse Salathiel arriscando uma estatística pouco ou nada científica - e o resultado técnico "era animador". Os negros "se portavam bem" contra os mais fortes adversários. Estavam no centro do espetáculo futebolístico então em crescimento: "quasi sempre os negros venceram e tiveram unanimidade das sympathias populares ${ }^{, 278}$. Eram verdadeiros protagonistas:

"A festa despertou notável interesse na massa popular (...) a torcida foi phantastica, principalmente a favor dos homens de côr, não deixando contudo, de seguir as regras de bôa educação" ${ }^{279}$.

Se as jogadas eram descritas como fonte de grande emoção, o jogo foi "um dos mais bellos e sensacionaes até hoje presenciados". Os brancos eram o "poderoso rival", mas os "rapazes do quadro preto exhibiram um futebol digno dos nossos campeões". Relevante salientar que a "victoria dos pretos surprehendeu", e não só pelo resultado final, com o que podemos supor uma expectativa de derrota dos negros, mas também "pela acção desenvolvida pelos vencedores, que vieram demonstrar todo o valor de uma raça!",280.

Podemos identificar nesse jogo um espetáculo do racismo para os brancos, que esperavam vencer os negros e, com isso, comprovar e atestar sua suposta superioridade racial. Enquanto, para os negros, ao menos para Salathiel de Campos, o jogo era um evento de militância, uma oportunidade de afirmar o "valor de uma raça".

Oswaldo Sylveyra, o Batepé, que "militava" com Salathiel Campos em $O$ Combate, repercutiu a vitória dos negros em 14 de maio de 1927 com bastante ironia, bom humor e racismo velado:

\footnotetext{
277 idem

${ }^{278}$ Idem, ibidem.

279 Idem, ibidem

${ }^{280}$ Idem, ibidem. Grifos nossos.
} 


\section{"Um duello entre a luz e a sombra}

Os pretos vingaram-se hontem. Justamente no dia 13 de Maio deram uma esfrega nos brancos, em justa 'revanche', ás chicotadas que receberam nos tempos da Princeza Isabel. É preciso não confundir preto com branco, porque de facto, a situação ahi por perto de 1880 para os filhos de 'Pae Zuão' era dolorosamente 'preta'. Isso é 'claro'...

O ventre livre estava no claro-escuro da esperança.

Mas... não estamos fazendo um historico da Aurea-Lei. Deixemolo a Paulo Setubal, que é campeão de historias, sem trocadilho.

$* * *$

O Friedenreich, esse moreno esbelto e agil, não teve mãos á medir. Enfarinhou o rosto de pó de arroz, ficando mais claro do que de costume. São coisas da...côr local.

$* * *$

Gente de todas as cores. Até mulato roxo estava alli no campo do preto e branco.

$* * *$

Desde os primeiros minutos os brancos perceberam que a coisa era 'preta'. Era preciso pôr o preto no branco. A situação, porem não se aclarava. Um empate de 2 pontos foi registrado no $1^{o}$ tempo.

$* * *$

Dica, a um tiro de El Tigre fica branco! Ataques negros que não se esclarecem. Ha um claro nas fileiras dos brancos: é a parelha de zagueiros. Não tem a 'côr' prorpia de sua habitual actuação. Para os brancos, a situação ennegrece...

$* * *$

O juiz não olha a branco nem preto. Vae apitando com clareza, sem mostrar obscuridad de actuação.

$* * *$

$3 \times 2$ a favor do 'quadro negro'.

Resta garantir a 'chicotada'. Os brancos estão escravos da 'linha preta'. 
Não se modifica o colorido da situação. Os pretos são agora 'alvos' da admiração geral.

Está escurecendo. A 'torcida' preta embranquece, ebria de victoria. Faltam 4 minutos.

$* * *$

Terminou. Victoria do 13 de Maio por $3 \times 2 !$...

O campo 'preteja' de gente.

$* * *$

Saem os quadros. Aos pretos são oferecidas chicaras de cafécom-leite. A outros, chocolate. Baixou o carvão. O leite desappareceu.

$* * *$

Mas...é claro. A victoria foi merecida, contentando a pretos e brancos, em toda a sua côr propria...

BATEPE ${ }^{, 281}$

Como dissemos, no segundo jogo (1928) o time dos negros saiu vitorioso novamente, e de novo "contra a espectativa". Entre os escalados, havia elementos que "militam na divisão secundaria da LAF". Salathiel também chama de "militância" a atuação dos jogadores de futebol, com a consequente conquista de espaço no futebol. Ponderando aqui o fato de este termo ser amplamente utilizado na época no sentido puro e simples de praticar certa atividade, sem necessariamente ter conotação política, Salathiel se considera um militante por defender a causa como jornalista e inclui também os jogadores na militância por terem cavado suas próprias trincheiras no seu âmbito de atuação no campo esportivo, o campo (de grama) e bola. Ainda que estes agentes (os jogadores) não se envolvessem diretamente com o movimento político propriamente dito (a Frente Negra Brasileira, por exemplo), eram também militantes dessa causa.

O terceiro jogo, em 1929, foi o último dos organizados pela LAF, até porque a liga amadora chegaria ao fim no ano seguinte. O campo da Floresta ${ }^{282}$ ficou lotado para este terceiro jogo, disputado com muita violência de ambas as partes, como mostram diversos jornais, tais como o próprio Correio Paulistano, o São Paulo Esportivo e a Folha

\footnotetext{
${ }^{281}$ Idem, ibidem.

${ }^{282}$ A Gazeta, Todos os Esportes, 13-05-1929, pg.12, coluna da direita.
} 
da Manhã. 283 “O público teve a impressão de que nenhum dos vinte e dois elementos deixou de sahir com uma pequena contusão que fosse", apontou este último veículo. ${ }^{284}$

Nessa partida, houve um empate por 2 a 2, mas não sem algumas suspeitas. “Causou má impressão a actuação do juiz, que torceu para os brancos, afim de interromper a $3^{\mathrm{a}}$ victoria dos pretos, o que lhes daria posse definitiva da Taça 'Princeza Isabel"” - três vitórias consecutivas garantiriam a posse - O São Paulo Jornal, por outro lado, chegou a afirmar que o empate foi justo ${ }^{285}$.

Apesar da interferência, após três anos consecutivos dos Jogos de 13 de maio, o selecionado negro demonstrou qualidade e permaneceu invicto contra os brancos, com isso alcançando "grande fama" - foram duas vitórias e um empate, com um total de nove gols feitos e seis gols tomados. Nesse mesmo ano de 1929, o Clube Atlético Brasil começa a ser um incentivador do time dos negros. Graças aos esforços desse clube, outros dois jogos aconteceram. O mais importante deles aconteceu em janeiro, antes mesmo da terceira partida da Taça Princesa Isabel.

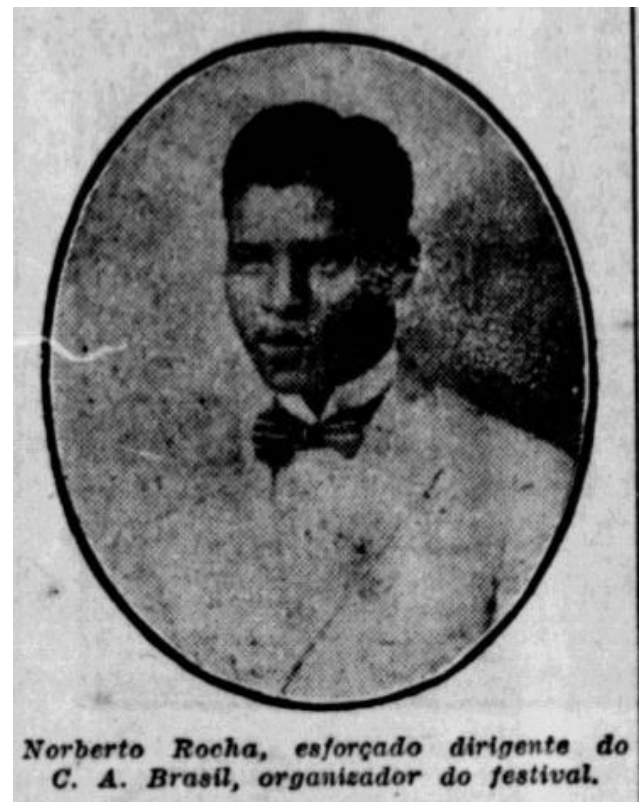

Imagem 09 - Norberto Rocha, dirigente do Clube Atlético Brasil. A Gazeta, Todos os Esportes, 19-01-1929. Pag 6, 4⿳亠丷厂 coluna.

Como mostrou George Andrews, Clube Atlético Brasil era um time de negros ${ }^{286}$, assim como o Associação Athlética São Geraldo - fundado em 1910, um pouco mais

\footnotetext{
${ }^{283}$ Correio Paulistano, Todos os Esportes, O Homem Negro no Esporte Bandeirante, 24-11-1934, pg.7. disponível em <http://hemerotecadigital.bn.br/acervo-digital/> acesso em 12/11/2014.. ${ }^{284}$ Idem.

285 Idem, ibidem.

${ }^{286}$ ANDREWS, George. Negros e brancos em São Paulo. Bauru: EDUSC, 1998.
} 
citado nos veículos na imprensa negra - vinculado a associações de homens negros em São Paulo. Foi fundado em 1916 como Clube Cravos Vermelhos, e só depois recebeu seu nome definitivo ${ }^{287}$. Ao menos desde $1928^{288}$, passou a disputar a segunda divisão da LAF. Se Salathiel de Campos ainda vislumbrava uma luta a ser travada, a inclusão de negros em postos de comando (como veremos mais adiante) ${ }^{289}$, os clubes negros eram os espaços onde essa experiência já acontecia. Como vemos na foto, o dirigente do C.A. Brasil era um negro, Norberto Rocha.

Organizado por este clube, em 1929 foi realizado o evento que marca o clímax do livro $O H N E B$ : uma partida do time de jogadores paulistas negros contra a seleção carioca (a oficial). Em parceria com a Associação Metropolitana de Esportes Athleticos (AMEA), do Rio de Janeiro, o C.A. Brasil conseguiu marcar o jogo para o dia 20 de janeiro, no campo do Independência, no Ipiranga. 290

Como disse Salathiel de Campos em OHNEB:

"Mercê das suas apreciaveis proezas, o selecionado preto conseguiu grande fama. Os cariocas, que através da sua imprensa, ás vezes estranhavam a existência desse conjunto, sob allegação de que isso viria crear o preconceito de côr, que não existia no Rio, duvidava do valor do conjunto negro." 291

E chegamos, finalmente, ao símbolo máximo da vitória do herói negro na narrativa de Salathiel de Campos, ao exemplo máximo da argumentação da sua militância, ou à síntese que sucede a tese e a antítese de seu livro. Um selecionado de negro paulistas disputaria um jogo contra um selecionado de cariocas. Uma seleção paulista inteira de negros. Se foi necessária muita militância para que Petro chegasse ao selecionado, se foi necessária um campanha em 1926 para que os jogadores negros "em grande fase" fossem convocados, e se foi necessária uma grande superação do lesionado Bisoca quando

\footnotetext{
${ }^{287}$ ABRAHAO, B. O. e SOARES, A. J. G.. A imprensa negra e o futebol em São Paulo no início do século XX. Rev. bras. educ. fís. esporte vol.26 no.1 São Paulo Jan./Mar. 2012. http://dx.doi.org/10.1590/S180755092012000100007

${ }^{288}$ A Gazeta, Todos os Esportes, Jogos de hoje dos Campeonatos lafeanos. 01-07-1928. Pg 8, primeira coluna.

${ }^{289}$ Correio Paulistano, Todos os Esportes, O homem negro no esporte bandeirante. 8-11-1934, pg.10. Disponível em <http://hemerotecadigital.bn.br/acervo-digital/> acesso em 12/11/2014.

${ }^{290}$ A Gazeta, Todos os Esportes, 19-01-1929. Pag 6, 4 coluna.

${ }^{291}$ Correio Paulistano, Todos os Esportes, O Homem Negro no Esporte Bandeirante, 28-11-1934, pg.7. Disponível em <http://hemerotecadigital.bn.br/acervo-digital/> acesso em 12/11/2014.
} 
tentaram sabotar sua participação, agora um time formado todo por negros representaria o estado de São Paulo contra os rivais da capital.

Entre os jogadores negros, jogaram: Waldemar; Giby, Ferreira, Mono, Bisoca, Rogerio, Martins, Petro, Friedenreich, Pedrinho e Picho. Pela seleção carioca, jogaram: Princeza; Aragão, Nauta, Theodomiro (Jucá), Heitor (Geraldo), Nilo; Camedo (Mica), Bahiano, Amir, Bianco, Cid. Na imprensa, esse time de negros era chamado de "“Quadro Brasil' da LAF" ${ }^{292}$. Era um quadro da liga dos amadores, organizado pelos negros do Clube Atlético Brasil.

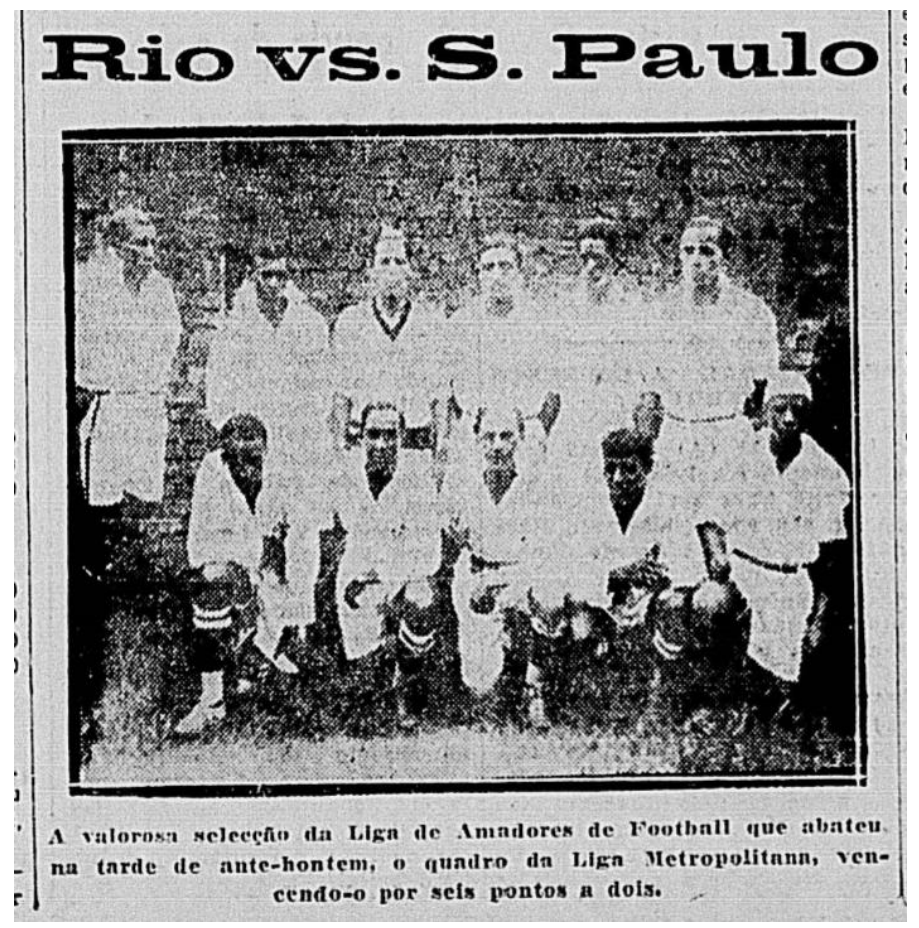

Imagem 10 - Selecionado paulista de jogadores negros, organizado pelo C.A. Brasil em parceria com a LAF. A Gazeta, Todos os Esportes, 22-01-1929. Pag 8, 2ª coluna.

O resultado foi arrebatador, veio como confirmação de muitos argumentos e ideias gestados na imprensa negra e veiculados depois por Salathiel de Campo no espaço que conquistou na imprensa paulista. O talento inato dos negros, para cuja lapidação só era necessário dar oportunidades de treino físico e moral, foi representado por esse jogo: 6 a 2 para a seleção de negros contra a seleção da capital brasileira. Uma vitória contundente.

Haja vista os relatos de que naquele dia caiu um grande temporal, que o campo estava em péssimas condições e poucas pessoas tiveram coragem de enfrentar a chuva para assistir à partida ${ }^{293}$, o que ficou para a posteridade e, principalmente, para o texto do $O H N E B$ foi o resultado.

\footnotetext{
292 A Gazeta, Todos os Esportes, 19-01-1929. Pag 6, 4a coluna.

${ }^{293}$ A Gazeta, Todos os Esportes, 22-01-1929. Pag 8, 2a coluna.
} 
Os jogos de 13 de maio em disputa da Taça Princesa Isabel continuaram sendo organizados nos anos seguintes pelo C.A. Brasil. Em 1930, vitória do time de negros por 5 a 0. Em 1931, vitória dos brancos por 5 a 2. Mas, neste ano, um outro evento chamou mais a atenção de Salathiel de Campos - que o descreveu em seu livro.

O selecionado dos paulistas negros enfrentaria novamente os cariocas, mas que dessa vez viriam jogar também apenas com jogadores negros. Entre os jogadores da capital estavam escalados "renomados campeões", entre eles os famosos Domingos da Guia e Leônidas da Silva. O resultado, deixaremos que Salathiel de Campos narre:

“Os paulistas, pondo em prática um jogo admirável e rico, impuzeram ao forte selecionado carioca dura derrota de 7 a $1, o$ que impressionou profundamente não só os paulistas como os cariocas. $" 294$

Este placar, hoje bastante gravado na memória dos brasileiros após a derrota frente a Alemanha na semifinal da Copa do Mundo de 2014, foi também alcançado pelo selecionado negro contra os cariocas. Vitória irreparável, o placar serviu para completar e encerrar essa primeira história do "homem negro no esporte bandeirante".

No ano seguinte, em 1932, a Frente Negra Brasileira foi responsável pela realização do jogo da Taça Princesa Isabel, não mais o C.A. Brasil. Realizado fora da data, em 25 de maio, o jogo terminou com uma grande vitória do time dos brancos por 6 a 1. Quem escolheu os jogadores do selecionado negro foi Friedenreich, uma figura curiosa nessa história toda.

Fried, como também o chamavam na época, foi talvez o maior expoente do futebol de sua época, ao menos no que diz respeito a história que ficou registrada e foi contada depois. Salathiel discordaria, ao que parece pelos seus textos. Diria, talvez, que o maior craque daquela época foi Tatú ou Petro. De qualquer forma, Friedenreich é um personagem e tanto. Foi um tanto quanto controverso: era um mestiço, que jogava no aristocrático Paulistano, e que parece ter sido o alvo de Salathiel de Campos quanto este fala em $O H N E B$ sobre os negros que não o querem ser, negros que negam a raça.

Nas duas primeiras edições da Taça Princesa Isabel, Fried jogou pelos brancos. $\mathrm{Na}$ terceira, estava também escalado para defender o time dos brancos, mas não jogou. Em 1929, joga pelo selecionado paulista de jogadores negros contra a seleção carioca da

\footnotetext{
${ }^{294}$ Correio Paulistano, Todos os Esportes, O Homem Negro no Esporte Bandeirante, 28-11-1934, pg.7. Disponível em <http://hemerotecadigital.bn.br/acervo-digital/> acesso em 12/11/2014.
} 
AMEA, e em 1932 - no evento da FNB - é ele quem escolhe o time dos negros na já narrada derrota por 6 a 1. É, de fato, uma figura complexa. Se dissemos que estas disputas foram uma guerra simbólica, Friedenreich foi um agente duplo.

Entre os grandes jogadores negros paulistas que estavam presentes no 7 a 1 (de 1931), apenas Waldemar atuou na Copa do Mundo de 1934, nenhum deles esteve em 1938. Entre os derrotados, Domingos e Leônidas participaram de ambas as Copas. Isso evidencia o quanto São Paulo ainda permaneceu fechada ao negro no futebol oficial, uma vez que vários bons jogadores, bons o suficiente para marcarem 7 a 1 em um time com grandes ídolos, não tinham mesmo espaço em times da Primeira Divisão ou tiveram vida curta no futebol, o que inviabilizou convocações para a seleção nacional. Fato agravado pelo fato da seleção brasileira ter sido um cabo de guerra entre as federações paulista e carioca durante esse período.

Vimos aqui como essa integração foi limitada. Ficando apenas dentro das quatro linhas, a integração dos negros no futebol não se desdobrou em uma assimilação social. A várzea deixou de ser ignorada, mas passou a ser uma espécie de mercado onde os dirigentes de futebol iam escolher os melhores jogadores para pinça-los e levá-los aos elencos do futebol oficial. Os outros continuavam na mesma condição que estavam antes. Mesmo os que se tornavam jogadores oficiais, tinham por pouquíssimo tempo alguma melhora em sua condição de vida, uma vez que, como vimos, não havia qualquer auxílio aos jogadores depois que eles não servissem mais ao futebol.

As disputas do time dos brancos contra os negros são muito representativas, por mais que o time dos negros jogasse melhor e vencesse, tinha também que vencer a arbitragem tendenciosa. Ainda, findo o jogo, os brancos retornavam aos seus postos sociais privilegiados, enquanto os negros voltavam para os porões das pensões e cortiços.

O capital esportivo, ou capital futebolístico, dos negros, especialmente nessa época de profissionalização, era muito valorizado. Porém, como vimos, a narrativa que Salathiel de Campos constrói sobre o negro no esporte bandeirante tem seus pontos altos todos vinculados ao amadorismo, especialmente à LAF e ao C.A. Brasil. Com esses aliados, Salathiel de Campos e os jogadores da época esperavam que acontecesse a troca de capital futebolístico por capital social. Isso aconteceu, mas de forma limitada, como vimos.

Ainda seria necessário fazer mais. Salathiel de Campos reconhece essa limitação da integração pela prática esportiva quando diz 
“Ora, ahi está outro problema a ser resolvido. Para bem geral é necessario ambientar completamente o homem negro na vida activa de nosso esporte, dando-lhe lugares de responsabilidade. ${ }^{295}$

O jornalista militante reconhece em seu livro, ao mesmo tempo, a vitória de sua mobilização e o trabalho que ainda estava por fazer.

Como vimos, Leopoldo Sant'Anna já havia militado pela entrada de jogadores negros no futebol oficial na virada dos anos 10 para os anos 20; em 1926, com participação direta de Salathiel de Campos, houve uma campanha para que atletas negros fossem convocados à seleção paulista de futebol; e, no início da década de 30, com a Frente Negra em franca expansão, Salathiel de Campos escreve e publica o Homem Negro no Esporte Bandeirante. Havia jogadores negros no futebol oficial e na seleção paulista, e o time dos negros se mostrou superior na disputa da Taça Princesa Isabel. Representando São Paulo contra os cariocas, ganharam de 6 a 2 e, depois, contra os negros da capital, de 7 a 1 . As trincheira foram cavadas e a primeira batalha foi ganha. Mas ainda havia outras a disputar.

\subsubsection{A razão do aparecimento do livro}

O livro OHNEB certamente repercutiu muito, sabemos que teve "franco sucesso", graças a algumas notas do jornal. Agora que já o analisamos melhor, voltamos à pergunta proposta no início deste trabalho: como é possível que esse livro tenha existido nessa época, com esse autor, e com esse conteúdo?

Chegamos à conclusão pelo que foi exposto que havia já há muito tempo um processo histórico que se desenrolou até chegar em Salathiel de Campos.

Ele não se politizou sozinho, conviveu nos espaços de sociabilidade negros, participou da imprensa negra, de movimentos sociais como a Frente Negra Brasileira e o Clube Negro de Cultura Social. Os espaços de sociabilidade eram uma realidade que vinha sendo construída desde a abolição, assim como a imprensa negra começa na virada do século XIX para o XX, e o movimento negro é construído na esteira desses dois elementos.

\footnotetext{
295 Correio Paulistano, Todos os Esportes, O homem negro no esporte bandeirante. 8-11-1934, pg.10. Disponível em <http://hemerotecadigital.bn.br/acervo-digital/> acesso em 12/11/2014.
} 
Suas opiniões e bandeiras não vieram do nada. A ideia de talento inato do negro vem das publicações da imprensa negra, da qual ele participou. Os argumentos a respeito do aperfeiçoamento físico do negro já se fazia presente em clubes como os já citados São Geraldo (de 1910) e C.A.Brasil (de 1916). Da mesma forma, sua ideia de raça brasileira, com destaque e valorização especial ao elemento negro, é uma construção de décadas que contou de forma importante com a militância do movimento negro da época e também, por que não, do patrianovismo (como vimos).

Também não falava sozinho. Tinha por trás de si a Frente Negra Brasileira e o Clube Negro de Cultura Social. Além disso, o veículo no qual publicou seu livro, que também dava a sustentação necessária para que Salathiel de Campos mexesse nessa caixa de marimbondos, o Correio Paulistano, era o veículo oficial do Partido Republicano Paulista. Isso significa que, além do apoio do movimento negro, Campos trabalhava junto de uma elite (financeira e política) paulistana. As motivações eram bastante diferentes daquelas do movimento negros, é claro. Esses paulistanos buscavam, após a derrota contra Vargas em 1932, "vencer pela ciência" (como dito no lema da Universidade de São Paulo), pretendiam reescrever sua história e valorizá-la, mostrá-la como heroica, em um esforço de apagar o passado rural e escravista para alcançar um tom conciliatório e apaziguador das tensões raciais.

Por fim, o próprio Salathiel de Campos. Inserido neste contex to que acabamos de descrever, o próprio jornalista é, por óbvio, uma das importantes razões que possibilitaram a existência dessa militância pela palavra escrita. Ele já acumulava a essa altura pelo menos duas publicações: $O$ cyclismo e o motocyclismo na vida esportiva paulista e Nossos Campeões. Já ocupava cargos importantes nos jornais de São Paulo, e tinha participado de importantes ações políticas (como aquela n'A Gazeta em 1926). Era um membro da elite negra daquela época, com capital cultural e social o suficiente para a missão que se propôs a cumprir. 


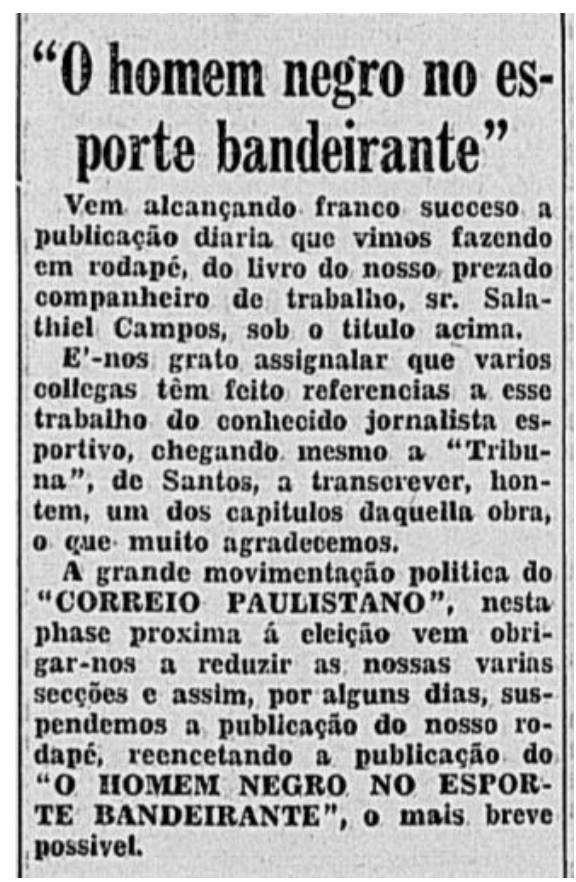

Imagem 11 - Notas do Correio Paulistano a respeito do livro O Homem Negro no Esporte Bandeirantei. 12/10/1934, pag 10, e 21/10/1934, pag 13.

Se a batalha pela inclusão de negros em cargos de direção ainda precisaria ser travada, Salathiel de Campos estaria em uma posição ainda melhor para enfrentá-la. Em 1935, aos 34 anos, ele que já era chefe da redação esportiva do Correio da Tarde, após a publicação de $O H N E B$ também passou a chefiar esta redação no Correio Paulistano ${ }^{296}$. Ele próprio era um exemplo de negro em um "cargo de responsabilidade", mas era um exemplo raro, e sabia disso.

${ }^{296}$ É provável que ele tenha sido promovido ainda em 1934, mas não foi possível confirmar. 


\section{Capítulo 3: Salathiel em ascensão, movimentos sob opressão (1935- 1938)}

O ano de 1935 do Correio Paulistano começou com destaque especial a Salathiel de Campos. No dia primeiro de janeiro, o jornalista publica 1934 e os esportes paulistas. Nesse texto que toma quase a página inteira, narra uma conversa, supostamente ouvida por ele em um Café Acadêmico na Praça do Patriarca. Não está claro se real ou fictícia, seus personagens são um nadador, um tenista, um esgrimista, um futebolista, um veterano, um jogador de basquete e um assistente, pontuados pelo que ele chama de "vozes".

No desenrolar da conversa, reproduzindo um discurso típico do próprio Salathiel, o futebolista diz que o "nosso mal (...) está no dinheiro", afirma que "enquanto as competições esportivas produzirem rendas sempre haverá os malandros que se locupletam á custa das habilidades dos jogadores". O profissionalismo "verdadeiro", continua o futebolista, "com toda sua organização, seria o ideal. Mas o que ahi está é apenas uma pílula dourada", uma "ilusão de optica", um "profissionalismo (...) pior que o amadorismo 'marron' porque os directores continuam a levar a parte do leão". E lista as rendas "dos socios, rendas dos portões, commissões sobre os jogadores", para dizer que com essa verba os campeonatos são fraudulentamente comprados e, portanto, "não há ideologia, não há moral, não há organização" ${ }^{297}$.

Assim foi feita a retrospectiva de 1934 pelo mais novo chefe de redação do Correio Paulistano: com múltiplas modalidades - a natação, o tênis, o basquete, a esgrima - e críticas ao profissionalismo, instaurado em 1933. Não necessariamente à ideia, que acabaria aceitando anos mais tarde, mas sim ao profissionalismo que então se praticava.

"O materialismo do seculo exige aos jogadores uma producção permanente", diz o veterano na conversa. O nadador então afirma que o único dali que está em melhores condições é o esgrimista, porque pratica um "esporte fidalgo e de linhas austeras de cavalheirismo, impõe disciplina, intelligencia e...educação".

O jornalista continua coerente com suas ideias, mas agora elas carregavam um peso maior. Salathiel estava mesmo em alta. Por ocasião da organização, pelo Jornal do Brasil, do $2^{\circ}$ Circuito Ciclístico do Distrito Federal, foram recebidas várias felicitações e parabenizações, mas a única que foi agradecida nominalmente pelo jornal foi a de

\footnotetext{
${ }^{297}$ Correio Paulistano, 1934 e os esportes paulistas. 01/01/1935, pag 12. Disponível em <http://hemerotecadigital.bn.br/acervo-digital/> acesso em 22/04/2015.
} 
Salathiel de Campos "competente cronista desportivo da paulicéa e um dos dedicados á causa ciclistica" ${ }^{298}$. No seu aniversário, uma nota do Correio Paulistano descreve o chefe de sua redação esportiva como "figura de destaque no esporte bandeirante, onde seu nome já está ligado ha já muitos anos", e acrescenta uma informação importante à biografia desse jornalista: à época, na "Empresa Jornalística de Informações Geraes", da qual foi fundador, ele ocupava o "posto de director" e batalhava "pelo esporte, nas suas varias modalidades" 299 .

Pouco tempo depois do aniversário de Salathiel de Campos, o delegado do Comitê de Organização da XI Olimpíada - realizada no ano seguinte, em Berlim - que encontravase em São Paulo, fez uma visita à redação do Correio Paulistano. Acompanhado de mais dois alemães, um deles radicado em São Paulo, foi recebido pelo chefe de redação em sua sala.

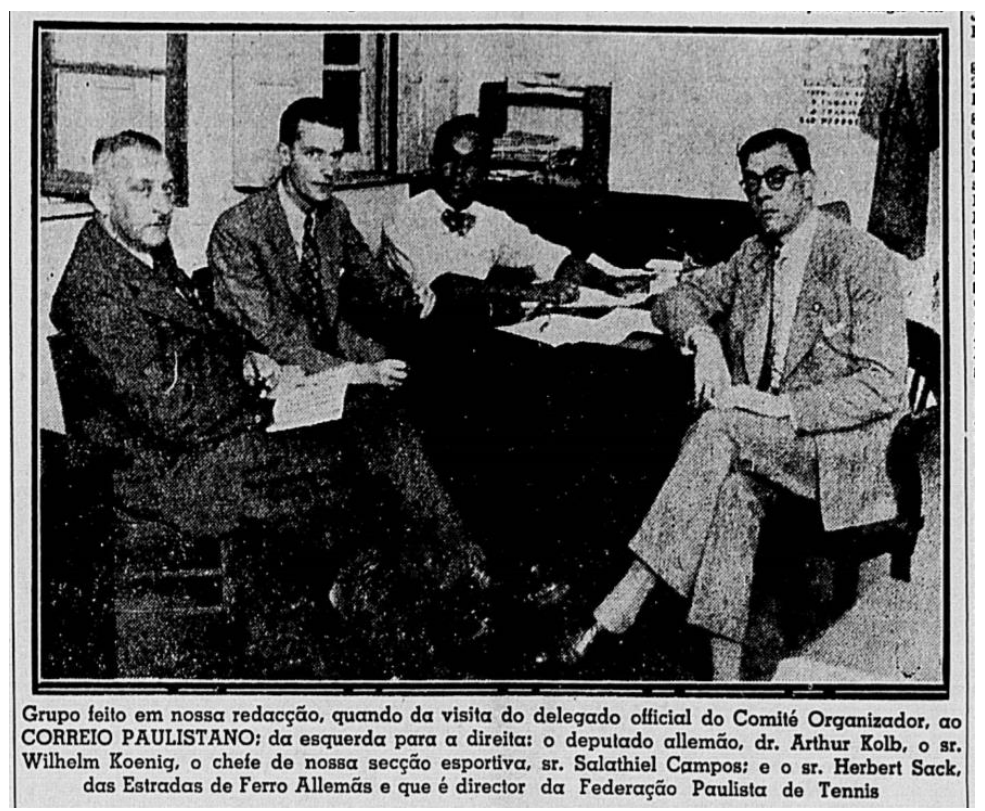

Imagem 12 - Fotografia de Salathiel de Campos com os visitantes alemães, 27/03/1935. ${ }^{300}$

Já com a carreira amadurecida, no momento em que, como vimos, talvez seja o ápice de sua trajetória profissional, Salathiel de Campos não se afasta da militância política. Por ocasião da prova 13 de Maio daquele ano, ele discursa em nome do Clube

\footnotetext{
298 Jornal do Brasil, Notas Desportivas, 10/10/1935, pag 15, sétima coluna. Disponível em $<$ http://hemerotecadigital.bn.br/acervo-digital/> Acesso em 01/05/2016

${ }^{299}$ Correio Paulistano, Todos os Esportes, Salathiel de Campos. 22/03/1935. Pag 7, segunda coluna. Disponível em <http://hemerotecadigital.bn.br/acervo-digital/> Acesso em 18/04/2015

${ }^{300}$ Correio Paulistano, Todos os Esportes, O nosso comparecimento às Olympiadas de Berlim. 27/03/1935. Pag 7, segunda coluna. Disponível em <http://hemerotecadigital.bn.br/acervo-digital/> Acesso em 18/04/2015
} 
Negro de Cultura Social, fazendo "homenagem aos homens negros ilustres da nossa história"301.

Mais ativa que manifestações públicas como essas seria sua militância nos jornais. Se ele era um jornalista politizado, militante do movimento negro, com um grande histórico de boas colaborações a essa luta, as Olimpíadas de 1936 apresentariam uma enorme oportunidade de retomar a discussão sobre o racismo. Entre a publicação de $O H N E B$ e a Olimpíada de Berlim, pouco ou nada se falou sobre raça. Em outubro de 1935, o Correio Paulistano ainda respondia em suas páginas a perguntas de leitores sobre o livro de Salathiel de Campos, mas o debate só voltaria às tintas do jornal quando atletas negros saíram da Alemanha nazista com medalhas de ouro.

\title{
3.1. Olimpíadas de 1936
}

\begin{abstract}
"Ali, no coração da velha Allemanha reuniram-se homens das cinco partes do universo. Gente de todas as nacionalidades, de todas as côres, de todas as raças, de todos os credos, ali esteve reunida em torno da arena das competições, justificando o dsitico que a grande Germania inscreveu nas bordas do seu sino olympico: 'Eu chamo a mocidade de todo o mundo'." Salathiel de Campos $^{302}$
\end{abstract}

Como o movimento negro recebeu o resultado das Olimpíadas de Berlim? Qual foi a leitura foi feita? Que tipo de comentário fizeram a respeito dos campeões negros na nação de Adolf Hitler? Que significações criaram a partir disso?

Salathiel de Campos pareceu ter aproveitado, como pôde, todas as aberturas que teve para falar sobre raça. Toda sua carreira até aqui foi marcada pela tomada para si daquilo que Edward Said chama de "poder de narrar". Como vemos:

"O poder de narrar, ou de impedir que se formem e surjam outras narrativas, é muito importante para a cultura e o imperialismo, $e$ constitui uma das principais conexões entre ambos. Mais importante, as grandiosas narrativas de emancipação $e$ esclarecimento mobilizaram povos do mundo colonial para que se erguessem e acabassem com a sujeição imperial; nesse processo,

\footnotetext{
${ }^{301}$ Correio Paulistano, 14/05/1935. Pag 9, 1ạ coluna. disponível em $<$ http://hemerotecadigital.bn.br/acervo-digital/> acesso em 02/09/2015.

302 Correio Paulistano, Todos os Esportes, Os campeões negros nas grandes olympiadas de Berlim. 19-081936, pg.10. Disponível em <http://hemerotecadigital.bn.br/acervo-digital/> Acesso em 08/01/2015
} 
muitos europeus e americanos também foram instigados por essas histórias e seus respectivos protagonistas, e também eles lutaram por novas narrativas de igualdade e solidariedade humana. "303

Nesse sentido, o que Salathiel de Campos fez desde o início da sua carreira até meados de 1936 foi tomar o poder de narrar. A sua versão foi a narrativa de emancipação, não contra a sujeição imperial, mas contra a sujeição da raça. É o que ele começou a fazer quando escreveu sobre o Bloco dos Caboclos (item 1.2): se opôs a narrativa eugenista construída por Monteiro Lobato (e outros), tomou para si o poder de narrar e começou a construir outra versão. Essa, elaborada não apenas por ele próprio, mas por todo repertório da imprensa negra e dos movimentos sociais dos quais, já vimos, ele participou. ${ }^{304}$

Sem dúvida é importante lembrar, apesar de óbvio, que não há uma unidade entre as pessoas negras. Significa dizer que essa narrativa foi construída pela elite negra da época, com todas as características que lhe são próprias, vistas até agora e que continuaremos a ver nas próximas páginas, e não pela população negra de forma geral. Então, seguimos.

No curto período em que foi realizada a Olimpíada de Berlim, em 1936, o jornalista ainda não tinha a sua coluna diária, como teria no ano seguinte. Mas, ao final da competição, escreveu uma série de três colunas nas quais exaltou os campeões olímpicos negros. A produção recebeu bastante destaque do jornal, que montou murais de fotos para ilustrar os textos de Salathiel de Campos, algo sofisticado para a época.

Já tratamos aqui sobre a importância de Salathiel de Campos no processo de desconstrução de um passado rural e escravista. Essa elite, que agora se pretende urbana e moderna, quer deixar no passado a escravidão e evitar conflitos com a população negra. Mas não com medidas inclusivas, investimentos, geração de empregos ou qualquer outra medida prática que seja. Esse projeto se dá apenas no campo das ideias. É importante destacar o local reservado para esse serviço: o caderno esportivo. Há espaço para que um negro atue na imprensa, e há espaço para que ele discuta a questão racial, tudo isso parte de um propósito maior da oligarquia estadual, mas não um espaço tido como nobre. Justamente por isso - e também por sua politização, militância e repertório - Salathiel de

\footnotetext{
${ }^{303}$ SAID, Edward W. Cultura e Imperialismo. São Paulo: Companhia de Bolso. 2011. Pag5.

${ }^{304}$ Agradeço a José Paulo Florenzano pela contribuição que deu nessa passagem da dissertação, tendo indicado a leitura de Edward Said.
} 
Campos extrapolou esse objetivo e levou para as páginas dos jornais a narrativa construída por ele e seus pares do movimento negro.

Podemos dizer que o caderno esportivo foi, nesse período, uma zona livre, conceito elaborado pelo antropólogo argentino Eduardo Archetti:

“'Zonas livres' são também espaços para misturas, para o aparecimento de híbridos, para a sexualidade e exaltação de performances corporais. Nas sociedades modernas, esportes, jogos e dança são loci privilegiados para a análise da 'liberdade' e criatividade cultural."

Isso significa dizer que Salathiel de Campos não militava em um caderno mais sério, por assim dizer. Seu espaço era a zona livre dos esportes. O período da sua carreira coincidiu com a expansão desses cadernos e a consolidação do que hoje chamamos “imprensa esportiva". Por isso, a essa altura, além de não ser um dos cadernos mais tradicionais - como os de política ou economia - a redação esportiva não estava completamente consolidada, ainda estavam em construção seu estilo, seus temas, suas abordagens, seus métodos, e também seus limites.

Na perspectiva de Salathiel de Campos, tanto melhor. Para ele, um especialista e entusiasta dos esportes, não importava o contexto. Importava, isso sim, que conquistara seu espaço para discorrer sobre aquilo que acreditava e defendia. E, inegavelmente, ele aproveitou a oportunidade.

\subsubsection{A utopia esportiva de Salathiel}

Já vimos repetidas vezes exemplos da admiração de Salathiel de Campos pela prática amadora do esporte. Uma congregação de cavalheiros, bem educados, intelectualmente privilegiados, e de uma moral supostamente irretocável, o esporte amador seria a expressão máxima desse tipo de sociabilidade. Dito isso, conseguimos entender melhor o jornalista quando ele diz que há "na vida da humanidade, um único elemento capaz de congregar todos os homens num amplexo de confraternização e cordialidade: o esporte" 306 .

\footnotetext{
${ }^{305}$ ARCHETTI, Eduardo P. 1999. Masculinities. Football, Polo and the Tango in Argentina. Oxford/New York: Berg. Pg 18.

Agradeço a Luiz Henrique de Toledo por esta contribuição que deu profundidade e embasamento à análise do espaço no qual Salathiel de Campos exerceu sua militância.

${ }^{306}$ Correio Paulistano, Todos os Esportes, Os campeões negros nas grandes olympiadas de Berlim. 19-081936, pg.10. Disponível em <http://hemerotecadigital.bn.br/acervo-digital/> Acesso em 08/01/2015
} 
Em 1936, o Partido Nazista Alemão já estava no poder, Adolf Hitler já comandava a nação germânica, quando mas a Segunda Guerra Mundial ainda não havia começado. Como nosso recorte temporal se encerrará às vésperas desse guerra, traremos para cá um texto de 1939, no qual Salathiel de Campos diz:

\section{"Hoje, em pleno seculo dos esportes, os campeões pullulam e as actividades esportivas dominam todas as espheras. \\ É justamente neste instante de dynamismo que a ambição humana vem interrompendo a marcha victoriosa da mocidade esportiva.}

Os canhões já troaram ao longo das fronteiras $e$ os homens já começaram a cahir, inanimados nos campos de batalha, e a ameaça continúa forte e perigosa.

Até quando a exaltações de sentidos ceifará tantas vidas e enfraquecerá o ideal do esporte, que é a expressão de fraternidade humana?"307

Para ele, o esporte, "expressão de fraternidade humana”, tinha potencial pacífico, de confraternização e harmonia, mas essa "marcha victoriosa da mocidade esportiva" no "seculo dos esportes" é interrompida pela guerra, pelas animosidades das "exaltações de sentidos”. Em certa medida, Salathiel de Campos tem razão. O século XIX, palco da sistematização dos jogos em esportes, o crescimento dessas práticas e sua disseminação pelo mundo, foi palco também do crescimento de impérios mundiais que, ao disputar cada rincão do planeta, acirraram tensões que se materializaram em duas grandes guerras mundiais. O século XX foi, como disse Salathiel de Campos, o século dos esportes, mas também foi o século das guerras. Frutos de duas sementes plantadas no século anterior.

Contrariando a ideia de congregação e fraternidade, um ano depois, em 1940, Salathiel de Campos diria que era preciso nacionalizar os esportes, e que o Botafogo do Rio de Janeiro merecia, realmente, a alcunha de "Glorioso" porque negou um jogador estrangeiro. não por falta de técnica, mas “porque não era brasileiro". ${ }^{308}$ Opinião coerente com o histórico patrianovista e frentenegrino de Salathiel de Campos, com seu nacionalismo, mas também, aparentemente, uma rigidez ampliada pelas tensões da guerra, que, para continuar falando de esporte, fez com que essa negação do estrangeiro

\footnotetext{
${ }^{307}$ A NOTíCIA, Ao correr da penna. 13/09/1939, pag 6. Disponível em <http://hemerotecadigital.bn.br/acervo-digital/> Acesso em 18/01/2015 ${ }^{308}$ A NOTíCIA, Ao correr da penna. 06/02/1940, pag 6. Disponível em <http://hemerotecadigital.bn.br/acervo-digital/> Acesso em 18/01/2015
} 
- especialmente do chamado Eixo (Alemanha, Itália e Japão) - levasse dois Palestras Itália a trocarem seus nomes. Um para Cruzeiro (Palestra Itália de Minas Gerais) e outro, Palmeiras (Palestra Itália de São Paulo), nomes tipicamente brasileiros.

Voltando a 1936, Salathiel de Campos escrevia com a Primeira Guerra Mundial em mente - que terminou quando, com 17 anos de idade, ele ainda não trabalhava na imprensa paulista - mas sem saber que haveria uma outra grande guerra à sua frente. E com esse aparato dizia:

"CANÇADOS das guerras, que sucedem os período de paz, mais ou menos curtos, os homens voltaram as suas vistas para os esportes e ha quarenta annos esse vehiculo benefico da civilização vem congregando as nações, num computo fraternal de força e dextreza. "309

O esporte utópico de Salathiel de Campos é amador, fraternal, pacífico, agregador de nações e raças.

\subsubsection{Um recado ao Brasil: os racistas dos EUA e os negros campeões}

Agosto de 1936, Salathiel de Campos imprime em sua coluna a "Licção que deverá ser aproveitada e nos vem dos... Estados Unidos". Apesar dos exemplos positivos que serão expostos, o jornalista militante já havia reconhecido o racismo dos norteamericanos quando disse:

"Os Estados Unidos, cuja civilização tem causado os mais desencontrados commentarios, são apontados como paiz preconceituoso de côr.

Realmente, ali, japonezes, chinezes e negros, encontram os maiores entraves ao seu progresso em varias partes do paiz; o negro especialmente, na zona da agricultura, tem soffrido os maiores vexames, por esse preconceito tolo e estupido, da côr, tanto mais estupido que assume a aspectos medievaes." 310

No entanto, diz ele, daquele país também vinham “exemplares que deixam 'a cara á bande'. Isso porque, no Estados Unidos da América, “os homens negros têm ascendido

${ }^{309}$ Correio Paulistano, Todos os Esportes, Os campeões negros nas grandes olympiadas de Berlim. 19-081936, pg.10. Disponível em <http://hemerotecadigital.bn.br/acervo-digital/> Acesso em 08/01/2015 310 Idem. 
a grandes posições que lhes dão fama e fortuna, correndo seus nomes pelos quatro cantos da terra" 311 .

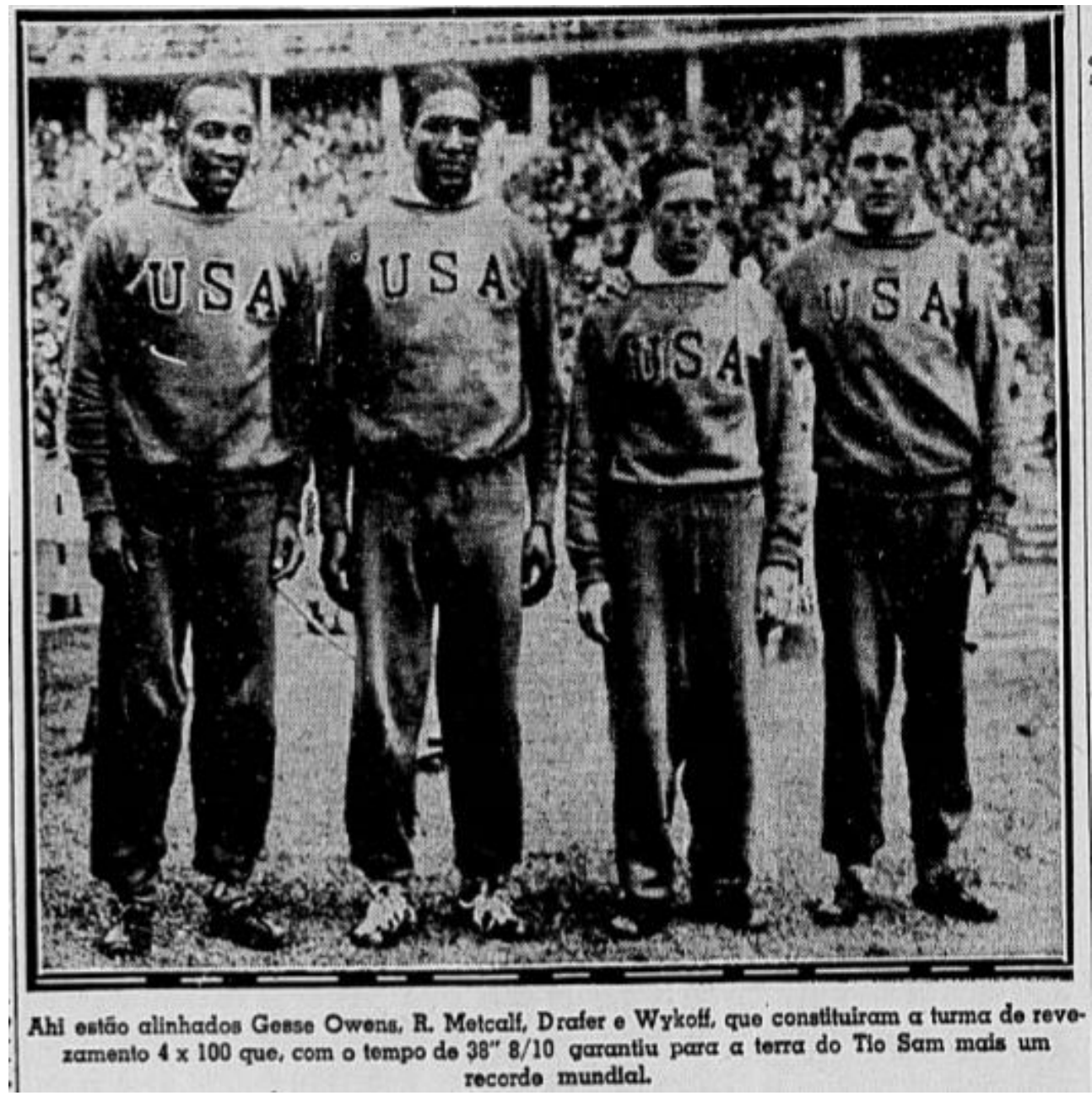

Imagem 13 - Fotografia dos campeões olímpicos do Estados Unidos, Correio Paulistano, 21/08/1936, pag. 10 .

Há nessa história momentos de grande simbolismo, como as quatro medalhas de ouro do atleta negro Jesse Owens em uma Olimpíada realizada no país do Partido Nazista. Mas nos Estados Unidos, na mesma época, era praticado um segregacionismo violento: a segunda organização da Ku Kux Klan - movimento suprematista branco de extermínio de negros - estava ativa; poucos anos antes, em 1933, a National Football League havia banido todos os atletas negros; também por volta dos anos 30, as ligas de basquete separavam-se baseadas em critérios raciais, o que mudaria apenas no final dessa década, quando algumas universidades do nordeste do país passaram a aceitar negros; na Primeira Guerra Mundial, soldados norte-americanos negros lutavam separados dos brancos, tinham piores equipamentos e pior treinamento; durante o New Deal dos anos 30, os

\footnotetext{
${ }^{311}$ Idem, ibidem.
} 
campos de trabalho dos negros eram separados, e essa população era sub-representada em postos de comando; estavam ativas em diversos estados da federação as chamadas leis Jim Crow, que reforçavam legalmente a segregação racial desde o fim da Guerra Civil norte-americana (1861-1965). ${ }^{312}$

Como já dissemos, a cidade de São Paulo na época de Salathiel de Campos era tão segregacionista quanto os Estados Unidos do mesmo período, com a diferença de não ter leis que consolidassem essa prática. Aparentemente, não era necessário ter leis para que se conseguisse segregar a população negra no Brasil, o que depõe contra o país, não a favor. Para Salathiel de Campos, ainda que reconhecesse o racismo dos EUA e também o de seu país, a presença de atletas negros nas delegações era um avanço. E de fato era. Não podemos menosprezar a valorização dessa integração, ainda que restrita e limitada, utilizando valores atuais. Fugindo ao anacronismo, a partir do que foi exposto até aqui, podemos ter dimensão da importância do desempenho desses atletas para o movimento negro da época.

É nessa chave que Salathiel de Campos fala, primeiro, das Olimpíadas de Los Angeles (1932), quando o país sede:

"...apresentou varios negros que se tornaram celebres,
sendo o universitario Tolan apontado como o mais
completo athleta e o melhor, dentre todos os concorrentes
ao certame. Daquella turma americana, quatro pretos se
tornaram recordistas." 313

E quatro anos depois, agora em Berlim, "os americanos mandaram athletas negros dos mais dextros", que foram, justamente eles, "as figuras principaes do torneio olympico" ${ }^{314}$, mostrando "o valor de sua raça". Não haveria palco e atuações mais perfeitas para o que Salathiel de Campos defendia: um nacionalista, especialista em esportes, que via a prática como ferramenta de confraternização e civilidade, e militante do movimento negro, viu, em uma competição esportiva entre nações, de múltiplas

\footnotetext{
312 WEST, Jean M. Jim Crow and Sports. Disponível em <https://web.archive.org/web/20021019142325/http://www.jimcrowhistory.org/resources/lessonplans /hs_es_sports.htm > Acesso em 11/08/2017.

${ }^{313}$ Correio Paulistano, Todos os Esportes, Os campeões negros nas grandes olympiadas de Berlim. 19-081936, pg.10. Disponível em <http://hemerotecadigital.bn.br/acervo-digital/> Acesso em 08/01/2015 314 Idem.
} 
modalidades, o sucesso de grandes atletas negros. As ditas qualidades inatas são novamente acionadas e, mais uma vez, os obstáculos e privilégios são problematizados:

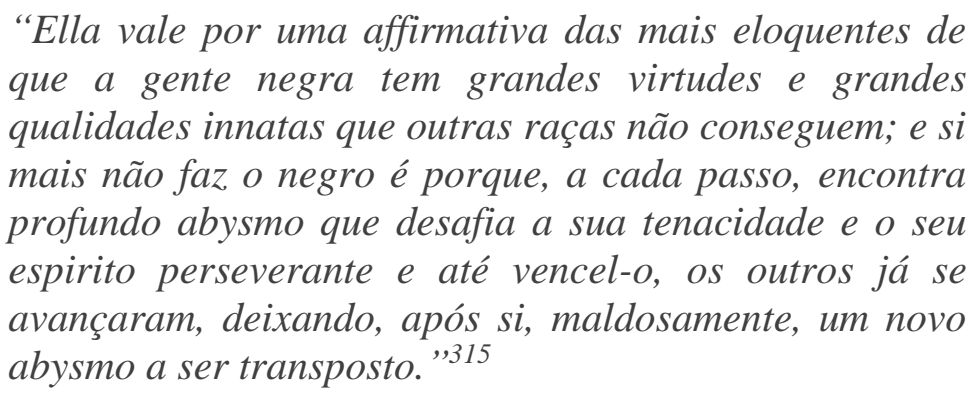

Na coluna seguinte, Salathiel de Campos estenderia a discussão, claramente demonstrando o caminho que o Brasil deveria ter seguido. Diz o jornalista: quando começaram as seleções dos atletas nos Estados Unidos, "foi novamente ventilada a questão racial", mas as entidades do país decidiram "não cogitar da côr do epiderme ou do sangue dos athletas, mas tão sómente do seu valor technico alliado ás suas qualidades moraes". Fosse de outra forma, os EUA teriam conquistado apenas a metade das medalhas de atletismo - onde os atletas negros eram mais aproveitados.

Essa questão das modalidades é de extrema relevância para falarmos da falsa integração das pessoas negras no esporte. O próprio Salathiel de Campos a discutira em OHNEB (1932/1934), ao falar dos custos de esportes como a esgrima, a natação e o tênis - como demonstramos aqui. A tolerância de dirigentes brancos a atletas negros se deu em poucos esportes, quais sejam: o futebol, o atletismo, o boxe e, mais tarde, o basquete.

O "preconceito de côr" ainda fechava as portas aos negros, mesmo nessas modalidades, no Brasil. Salathiel de Campos opõe os EUA ao seu país ao dizer:

"Sabendo-se que, infelizmente, ainda existe naquelle paiz [EUA] o preconceito da côr, a presença desses elementos na delegação americana em nada a deslustrou. Ao contrario, só lhe proporcionou glorias.

(...)

Além de uma lucta ingloria, que veiu dar ao estrangeiro a mais desagradavel impressão anarchia [tratando-se de um patrianovista, "anarquia" aqui é clara e propositalmente utilizada de forma pejorativa] esportiva que por aqui anda, a delegação brasileira prescindiu-se

315 Idem, ibidem. 


\section{de alguns bons elementos, estribando-se veladamente no preconceito da côr." 316}

E, como ainda vemos atualmente em diversas áreas - acadêmica, corporativa, artística -, os negros, em cada uma das modalidades, tinham vetada a sua participação enquanto "elementos, que a pittoresca gyria esportiva chama de 'pernas de pau', partiram daqui para a Europa, para gozar apenas a delicia de uma viagem de recreio" 317 . Foi o caso de Nestor Gomes, "accintosamente" posto à margem "devido de alguém que lhes cubiçara o lugar na delegação e, possuindo olhos azues e cabellos castanhos, lhes tomara o posto" ${ }^{318}$.

No Capítulo 1, falamos do início do samba no Rio de Janeiro e da marchinha que Eduardo das Neves compôs, em 1902, homenageando Santos Dumont, que havia voado em torno da Torre Eiffel em Paris um ano antes. Pois Salathiel, que nasceu no ano desse famoso voo de dirigível, cita essa canção na terceira e última das colunas a respeito das Olimpíadas de Berlim. O “admirado e saudoso" Dudu das Neves, como diz o autor, num "arroubo de patriotismo" compôs:

\section{"A velha Europa curvou-se ante o}

[Brasil,

Terra, amada do indio audaz e guer-

[reiro.

A maior gloria do seculo $X X$

É Santos Dumont, um brasileiro",319

Então, propõe Salathiel de Campos que os negros do mundo, parodiando o "grande artista do violão", poderiam da mesma forma "cantar em versos e epopéa dos seus irmão, que acabam de impressionar o mundo nas Olympiadas de Berlim" ${ }^{320}$. E por que diz isso?

Atento às movimentações políticas mundiais, o jornalista já não parece concordar com uma suposta defesa da raça nos moldes apresentados pelo jornal $A$ Voz da Raça, que chegou a elogiar Adolf Hitler por defender a raça ariana e afirmar que os negros deveriam

\footnotetext{
${ }^{316}$ Correio Paulistano, Todos os Esportes, Uma grande turma de revezamento. 21-08-1936, pg.10. Disponível em <http://hemerotecadigital.bn.br/acervo-digital/> Acesso em 08/01/2015

317 Idem.

318 Idem, ibidem.

${ }^{319}$ Correio Paulistano, Todos os Esportes, Os campeões negros que participaram das Olimpíadas de Berlim. 30-08-1936, pg.14. Disponível em <http://hemerotecadigital.bn.br/acervo-digital/> Acesso em 08/01/2015

${ }^{320}$ Idem.
} 
fazer o mesmo que o führer. ${ }^{321}$.Afastando-se de Arlindo Veiga dos Santos, líder da Frente Negra Brasileira, Salathiel de Campos diz que:

\section{"Tanto mais essa situação brilhante dos homens negros em Berlim é importante, porque vem focalizar o valor da raça, neste momento grave porque o mundo atravessa, em que se pretende pôr á prova a supposta supremacia racial. "322}

Se, em um primeiro momento, o jornalista parece ter concordado com essa visão, por concordar com Arlindo Veiga quando este diz que cada raça e nação deveria defender a si mesma ${ }^{323}$, agora, a preocupação maior de Salathiel de Campos é negar a "supposta supremacia racial”.

Há indícios de que este jornalista mantinha contato com movimentos negros dos Estados Unidos, ou ao menos acompanhava notícias a esse respeito, porque afirma que os resultados obtidos pelos atletas animaram a "raça negra" e "segundo noticias recebidas recentemente dos Estados Unidos, as communidades da raça vão desenvolver intenso trabalho para o progresso de elementos negros em outras modalidades esportivas afim de que possam obter um exito mais completo em todos os sectores esportivos"324.

Mais uma vez, vemos novas trincheiras que precisavam ser cavadas. Já vimos aqui a necessidade de lutar pela presença de negros em "cargos de responsabilidade", agora, vemos apresentada a necessidade de ampliar sua participação em outras modalidades. Empolgados pelas conquistas que vinham tendo, os integrantes do movimento negro já se preparavam para as próximas batalhas. Afinal:

\section{"Que nos sirva, ao menos, o exemplo que acaba de dar ao mundo os Estados Unidos, porque nesta terra tropical regada com o suor, as lagrimas e o sangue de africanos, não se póde deixar á margem os homens negros. "325}

\footnotetext{
${ }^{321}$ A Voz da Raça, São Paulo, 09/12/1933, pag 1.

322 Correio Paulistano, Todos os Esportes, Os campeões negros que participaram das Olimpíadas de Berlim. 30-08-1936, pg.14. Disponível em <http://hemerotecadigital.bn.br/acervo-digital/> Acesso em $08 / 01 / 2015$

${ }^{323}$ A Voz da Raça, São Paulo, 09/12/1933, pag 1.

${ }^{324}$ Correio Paulistano, Todos os Esportes, Os campeões negros que participaram das Olimpíadas de Berlim. 30-08-1936, pg.14. Disponível em <http://hemerotecadigital.bn.br/acervo-digital/> Acesso em 08/01/2015

325 Idem.
} 


\subsection{Ao correr da penna}

Em 1937, Salathiel de Campos passou a ter uma coluna diária (ou quase), com um nome menos original (para a época) do que seu conteúdo: Ao correr da pena. Seria publicada neste jornal por três anos, até o final de 1939. Somente esses textos já possibilitam uma variedade grande de análises. Podemos ler sobre a profissionalização, a "pacificação" do futebol paulista, a violência no esporte, a presença da polícia em jogos de futebol, a questão racial, a Copa de Futebol de 1938, e até colunas mais prosaicas, como por exemplo quando descreve o trabalho de um jornal, desde a reportagem e redação até a impressão nas oficinas.

Neste ano, é instaurado o Estado Novo de Vargas, após a farsa do Plano Cohen, levado a cabo em setembro. O plano, supostamente apreendido pelas Forças Armadas, planejava uma nova insurreição armada, à imagem e semelhança da Intentona Comunista de 1935. Falava-se em agitar operários e estudantes, liberar presos políticos, incendiar casas e prédios públicos, e matar autoridades civis e militares que oferecessem resistência. Lira Neto explica a construção da farsa em sua biografia de Getúlio Vargas:

"O Chamado Plano Cohen - o nome judaico era particularmente sugestivo - detalhava as supostas ações que os comunistas estariam planejando para instituir um governo de extrema-esquerda no Brasil

(...)

O Plano Cohen era flagrantemente falso. Fora escrito no final de agosto pelo então coronel Olímpio Mourão Filho, chefe do serviço secreto da Associação Integralista Brasileira. De acordo com o que admitiria mais tarde o próprio Mourão, o texto teria sido redigido por ele a pedido de Plínio Salgado, mas como um exercício teórico. Tratava-se de um boletim aos integrantes do movimento dos camisas-verdes, composto de dois capítulos. No primeiro, faziam-se recomendações gerais (...) no segundo, para efeito didático, mimetizava-se um plano de operações comunista (...) $O$ primeiro capítulo foi 
suprimido do conhecimento público e o segundo, tratado

à época como um documento autêntico.",326

Sob esse pretexto é que Vargas sustenta a necessidade de sua ditadura, o Estado Novo. Isso é importante porque falamos aqui do que talvez seja o auge da carreira de Salathiel de Campos, mas, no que diz respeito à militância, não há momento pior. Em 2 de dezembro daquele ano, o decreto-lei $\mathrm{n}^{\circ} 37$ colocaria na ilegalidade os partidos políticos e, entre eles, os movimentos nos quais Salathiel militava:

\section{"Art. $1^{\circ}$ Ficam dissolvidos, nesta data, todos os partidos políticos.}

$\S 1^{\circ}$ São considerados partidos políticos, para os efeitos desta Lei, tôdas as arregimentações partidarias registadas nos extintos Tribunal Superior e Tribunais Regionais da Justiça Eleitoral, assim como as que, embora não registadas em 10 de novembro do corrente ano, já tivessem requerido o seu registo. "327

Eram igualmente atingidas "as milícias cívicas e organizações auxiliares dos partidos políticos", vedado o "o uso de uniformes, estandartes, distintivos e outros símbolos", apesar de ser permitido "continuarem a existir como sociedade civil para fins culturais, beneficentes ou desportivos, dêsde que o não façam com a mesma denominação com que se registraram como partidos políticos" ${ }^{328}$. Por essa abertura, o Clube Negro de Cultura Social ficaria ativo por mais um ano ainda.

Porém, em 1938, no cinquentenário da abolição da escravidão, foi alvo de uma batida da polícia repressora de Vargas que o fechou arbitrariamente. Para que continuasse funcionando, deveria deixar de utilizar o termo "negro" em seu nome e deixar de realizar atividades políticas. Meses depois, a organização deixaria de existir ${ }^{329}$.

Ao longo do ano de 1937, Salathiel de Campos se alinha à ideia do esporte como manifestação nacional, apoia o controle centralizado do esporte pelo Estado, e continua a debater a questão racial sempre que pode, mas sem deixar de valorizar, muito mais, o esporte bandeirante. Sua atuação continua, e isso é importantíssimo, porque a atuação da

\footnotetext{
326 NETO, Lira. Getúlio (1930-1945): Do governo provisório à ditadura do Estado Novo. São Paulo: Companhia das Letras, 2013. Pag. 304.

327 Diário Oficial da União - Seção 1 - 4/12/1937, Página 23961. Disponível em < http://www2.camara.leg.br/legin/fed/declei/1930-1939/decreto-lei-37-2-dezembro-1937-354175publicacaooriginal-1-pe.html> Acesso em 13/11/2017. 328 Idem.

329 DOMINGUES, Petrônio. Paladinos da Liberdade: a experiência do Clube Negro de Cultura Social em São Paulo (1932-1938). Revista de História 150 (1o - 2004), 57-79. Pag 76.
} 
Frente Negra Brasileira se encerra, deixando por mais de uma década um vácuo importante na organização política de movimentos negros. A ditadura militar traria ainda mais opressão a esses movimentos, e essas barreiras consecutivas são as principais causas para que, ainda, em pleno século XXI, sejam discutidas obviedades a respeito do racismo.

\subsubsection{Campos no Correio Paulistano, Mazzoni n'A Gazeta}

Desde a volta do Correio Paulistano à ativa, em 1934, ano da publicação de OHNEB, deixam de aparecer reportagens ou colunas de Salathiel de Campos n'A Gazeta. Não foi possível confirmar se ele, de fato, deixou o jornal. Três anos depois de Thomaz Mazzoni assumir a chefia da seção esportiva do jornal, Cásper Líbero, o dono, adere ao governismo e aproxima-se de Getúlio Vargas, chegando a propor que a Universidade de São Paulo outorgasse um título de doutor honoris causa ao governante ${ }^{330}$. Mazzoni parecia, certa medida, alinhado aos rumos que o varguismo estava tomando e, se isso for verdade, também parecia ver com bons olhos a proximidade do seu jornal com Vargas.

Como diz Rafael Silva em seu artigo Imprensa Esportiva e o pensamento autoritário na obra de Thomaz Mazzoni, para o chefe da redação esportiva d'A Gazeta “todo o mal que atingia o futebol brasileiro era fruto do 'regime de livre ação', que não trouxera 'nenhuma paz, nenhuma organização' para 'garantir o bom futuro do esporte brasileiro'. Por isso, era necessário 'modificarmos radicalmente o regime esportivo

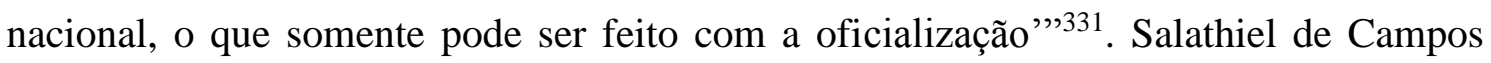
dificilmente se encaixaria nessa linha editorial.

É possível identificar vários pontos de discordância entre os dois chefes de redação. O jornalista italiano na coluna Olimpicus, o jornalista negro, na coluna Ao Correr da Penna.

Se $A$ Gazeta, de Thomaz Mazzoni, às vésperas do Estado Novo e mesmo depois de seu início, era notadamente governista, o Correio Paulistano, de Salathiel de Campos, era declaradamente oposicionista. Se a redação esportiva comandada por Thomaz Mazzoni defendia o profissionalismo, e dizia que "toda a prática esportiva para ser útil ao

\footnotetext{
330 NETO, Lira. Getúlio (1930-1945): Do governo provisório à ditadura do Estado Novo. São Paulo: Companhia das Letras, 2013. Pag. 392.

${ }^{331}$ MAZZONI, Thomaz. IN SILVA, Rafael. Imprensa esportiva e o pensamento autoritário na obra de Thomaz Mazzoni. Anais do XV Encontro Regional de História da ANPUH-RIO. ISBN: 978-85-65957-00-7.
} 
país deve estar "dentro da doutrina do Estado Novo""332, Salathiel de Campos defendia o exato oposto ao dizer que o "futebol nacional está correndo um grande risco de decadencia technica, motivado pelo interesse profissional" ${ }^{333}$.

Apesar de seguirem caminhos diferentes, ambos concordavam que o esporte era "força viva da nação" 334 , nas palavras de Mazzoni. Vimos Salathiel de Campos dizer algo bastante parecido em seus textos sobre as Olimpíadas de 1936. Porém, nesse momento de acirramento das tensões políticas, o chefe de redação do Correio Paulistano estava mais preocupado com o "futebol bandeirante, qual velha civilização esportiva", esporte pelo qual "São Paulo se fez notar como o maior centro do paiz”, após criar "a chamada 'escola paulista', que foi a 'chave' de ouro da vida futebolistica do paiz, feita de energia, vivacidade e intelligencia" ${ }^{\prime 335}$.

Se identificamos em Salathiel de Campos um saudosismo, em Mazzoni acontece o contrário:

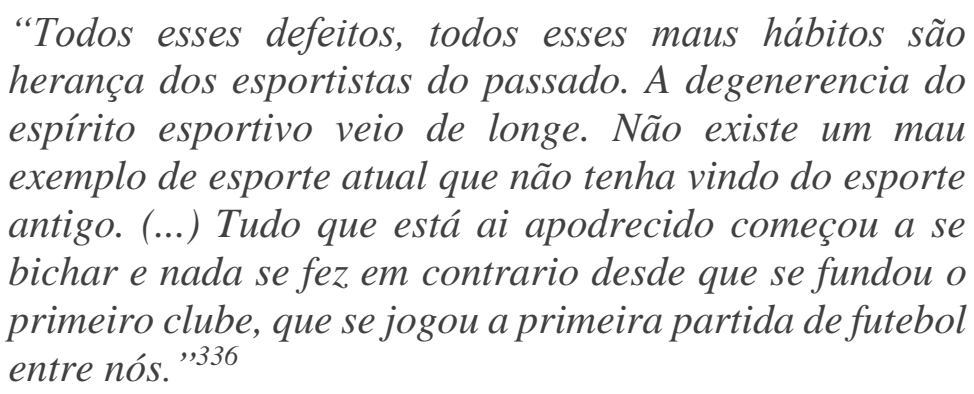

Ambos criticam o que chamavam de "clubismo", mas de formas bem diferentes. Para Mazzoni, esse clubismo é sintoma generalizado da "livre ação de particulares" que tanto critica, fenômeno que levava dirigentes a trabalhar única e exclusivamente pelos seus clubes, o que gerava cisões e indisciplina ${ }^{337}$, uma vez que agiam, cada um dos clubes, como partidos políticos - termo este, aliás, utilizado de forma pejorativa. Para o jornalista ítalo-brasileiro, a centralização e oficialização do esporte sob comando do Estado - o Estado Novo - seria a solução. Uma forma de pôr fim a ação "irresponsável perante a

\footnotetext{
332 Idem.

${ }^{333}$ Correio Paulistano. Ao Correr da Penna. 09/10/1937, pag 10, primeira coluna. Disponível em <http://hemerotecadigital.bn.br/acervo-digital/> Acesso em 10/04/2015

${ }^{334}$ MAZZONI IN SILVA, Rafael. Imprensa esportiva e o pensamento autoritário na obra de Thomaz Mazzoni. Anais do XV Encontro Regional de História da ANPUH-RIO. ISBN: 978-85-65957-00-7.

${ }^{335}$ Correio Paulistano. Ao Correr da Penna. 14/10/1937, pag 10, primeira coluna. Disponível em $<$ http://hemerotecadigital.bn.br/acervo-digital/> Acesso em 10/04/2015

${ }^{336}$ MAZZONI, Thomaz, 1939, IN SILVA, Rafael. Imprensa esportiva e o pensamento autoritário na obra de Thomaz Mazzoni. Anais do XV Encontro Regional de História da ANPUH-RIO. ISBN: 978-85-65957-00-7 337 Idem.
} 
coletividade" de "politiqueiros" 338 . A centralização nas mãos do Estado é que garantiria, então, que o bem coletivo fosse colocado em primeiro lugar.

Salathiel de Campos já criticara "clubismo", em 1934, ao falar sobre um passado recente, ao dizer que este "oblitera a intelligencia do individuo" 339 , o que, naquele contexto, significava ignorar o desempenho dos atletas negros e criticar a campanha realizada n'A Gazeta em 1926. Depois, diz que o "clubismo" é "o mais pernicioso de todos os elementos" 340 , e, ainda em outra coluna, diria que o amadorismo, "verdadeiro ou não", era despido "da paixão contagiosa do clubismo", pois o "publico procurava avidamente os encontros entre os grandes clubes porque, além do aspecto esportivo, os contendores exhibiam um jogo de grande classe". Com o "clubismo" o futebol "modificou-se para peor. Applica-se uma especie de regra de tres inversa: quanto mais clubes sejam fortes menos espectaculosidade e belleza de actuação" ${ }^{341}$. E o profissionalismo piora essa situação, uma vez que o "futebol profissional, a despeito dessa apparente cultura, é um vulcão em que se entrechocam os interesses e paixões clubisticas" $" 342$.

Para Mazzoni, o “clubismo” era manifestação de uma livre organização nociva ao esporte, que deveria, isso sim, ser controlado e regulado por um Estado forte e centralizador, o que garantiria que o bem coletivo fosse privilegiado. Para Salathiel de Campos, o clubismo era uma manifestação perniciosa, contagiosa e que oblitera a inteligência, faz com que o interesse pelo clube se sobressaia ao interesse pelo esporte, situação agravada ainda mais pelo profissionalismo. Uma visão típica do amadorismo, que admira o esporte pelo esporte, em um quase parnasianismo esportivo.

Outra discordância importante entre os dois diz respeito ao esporte local. Como já vimos repetidas vezes, Salathiel de Campos preza pelo estado de São Paulo, pelo esporte bandeirante, um admirador e apoiador de certa elite local, de quem era empregado. Mazzoni, por outro lado, era um crítico do bairrismo, segundo ele um desvirtuador do

\footnotetext{
338 Idem, ibidem.

${ }^{339}$ Correio Paulistano, Todos os Esportes, O Homem Negro no Esporte Bandeirante. 03/11/1934. Pag 7, rodapé. Disponível em <http://hemerotecadigital.bn.br/acervo-digital/> acesso em 12/11/2014.

${ }^{340}$ Correio Paulistano, Todos os Esportes, Ao Correr da Penna. 02/10/1937. Pag 10, primeira coluna. Disponível em <http://hemerotecadigital.bn.br/acervo-digital/> acesso em 10/14/2015.

${ }^{341}$ Correio Paulistano, Todos os Esportes, Ao Correr da Penna. 30/11/1937. Pag 10, primeira coluna. Disponível em <http://hemerotecadigital.bn.br/acervo-digital/> acesso em 10/14/2015.

${ }^{342}$ Correio Paulistano, Todos os Esportes, Ao Correr da Penna. 11/12/1937. Pag 10, primeira coluna. Disponível em <http://hemerotecadigital.bn.br/acervo-digital/> acesso em 10/14/2015.
} 
esporte $^{343}$. Como diz Rafael Silva no artigo já citado, a ideologia formulada pelo Estado Novo pretendia suprimir paixões estaduais em função de um patriotismo único, celebrando a consciência de nacionalidade acima de qualquer outra. Mazzoni, que seria considerado um estrangeiro pelos militantes do Movimento Pátria-Nova e da Frente Negra brasileira, dada sua origem italiana, estava muito mais próximo ideologicamente desse ideal nacionalista do que Salathiel de Campos, que era um porta voz do estado de São Paulo.

Se, para Mazzoni, a imprensa colaborava com o clubismo e o bairrismo, ao incentivar o que chamava de "choro" ${ }^{444}$, para Salathiel de Campos:

"Os esportes tiveram na imprensa o seu maior e mais
benefico auxiliar, sob todos os pontos de vista e
continuam a ser bafejados por esse trabalho precioso e
gratuito dos incentivadores anonymos, occultos nas
columnas dos jornaes." 345

Mas nem só discordâncias há entre esses dois grandes jornalistas. Em pleno Estado Novo, é possível dizer que essa concordância tenha sido artificial, uma vez que uma voz muito dissonante logo seria calada. De qualquer forma, em determinado momento Mazzoni e Campos concordam, em linhas gerais, sobre como deve ser organizado o esporte nacional. Em sua coluna Olimpicus, na governista A Gazeta, Mazzoni diz:

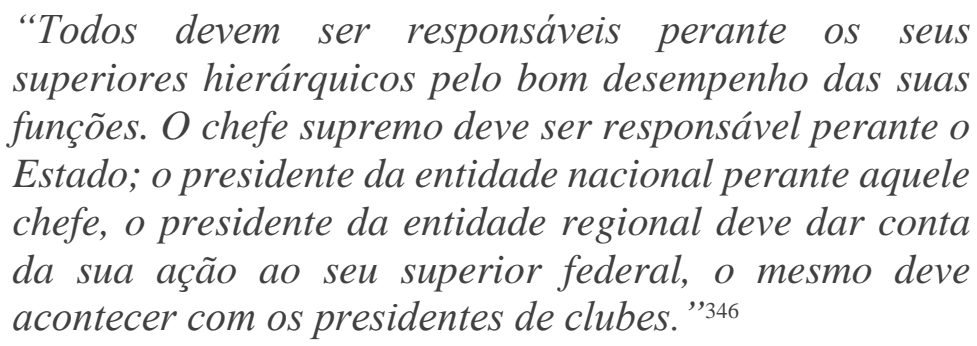

Salathiel de Campos, em sua coluna Ao Correr da Penna, no oposicionista Correio Paulistano, diz:

\footnotetext{
343 MAZZONI, Thomaz, 1939, pag 75. IN SILVA, Rafael. Imprensa esportiva e o pensamento autoritário na obra de Thomaz Mazzoni. Anais do XV Encontro Regional de História da ANPUH-RIO. ISBN: 978-8565957-00-7

344 Idem.

${ }^{345}$ Correio Paulistano, Todos os Esportes, Ao Correr da Penna. 23/12/1937. Pag 14, primeira coluna. Disponível em <http://hemerotecadigital.bn.br/acervo-digital/> acesso em 10/14/2015.

346 Idem.
} 
"O esporte, na concepção moderna da arte de governar ou da organização geral dos poderes publicos, é funcção do Estado.

$(\ldots)$

Ainda há pouco, referindo-se a criação do Departamento Esportivo do Reich, o chanceller Adolf Hitler, determinou as funç̧ões do novel departamento, visando contribuir para a uniformização do esporte allemão,

Ora, no Brasil, dentro do Estado Novo, é possivel resolver-se de vez essa questão esportiva, criando um departamento controlador do assumpto. "347

Disso tudo podemos concluir que, entre os dois chefes de redação desses importantes jornais paulistanos, Thomaz Mazzoni era o que tinha um arcabouço de opiniões e argumentos mais próximo do Estado Novo. Porém, contra intuitivamente, como nos mostra Denaldo Alchorne de Souza, o profissionalismo apoiado pelo ítalobrasileiro não ajudava na "consolidação da ideologia estadonovista do enaltecimento do trabalho", nem queria ter nos jogadores negros profissionalizados símbolos "de uma democracia racial" 348 . O autor diz que "para os ideólogos do regime", o trabalhador de carteira assinada "contribuía no engrandecimento da nação" e "criava riquezas" ${ }^{349}$, o que não era o caso dos atletas.

Para Vargas e os ideólogos do Estado Novo, os esportes “eram parte da educação física e social dos indivíduos e nesse sentido não comportaria o ganho salarial” ${ }^{\text {"350 }}$. $\mathrm{O}$ historiador Denaldo Alchorne de Souza nos apresenta uma carta do ministro da Educação e Saúde Pública, Gustavo Capanema, a Getúlio Vargas, que nos ajuda a entender a questão:

"Não se deve ainda esquecer a tendência, verificada entre nós, como em outros países, à profissionalização de grande número de atividades desportivas, fato (...) que precisa ser objeto da máxima atenção dos responsáveis pela educação nacional, visto como não se pode deixar de

\footnotetext{
${ }^{347}$ Correio Paulistano, Todos os Esportes, Ao Correr da Penna. 01/12/1937. Pag 10, primeira coluna. Disponível em <http://hemerotecadigital.bn.br/acervo-digital/> acesso em 10/14/2015.

${ }^{348}$ DE SOUZA, Denaldo Alchorne. O Brasil entra em campo, Construções e reconstruções da identidade nacional (1930-1947). São Paulo: Annablume, 2008. Pag 92.

349 Idem.

${ }^{350}$ Idem, ibidem.
} 
reconhecer que somente o amadorismo desportivo constitui processo educativo por excelência, merecendo portanto do governo amparo especial e orientação conveniente" 351

Nesse sentido, Salathiel de Campos poderia muito bem ter sido um desses ideólogos, ao menos no que diz respeito ao esporte. O que Vargas e sua cúpula perceberam rapidamente - e Salathiel de Campos concordaria no ano seguinte (1938) - é que o esporte, especialmente as Olimpíadas e a Copa do Mundo de Futebol, é um verdadeiro embate simbólico entre nações, o que o torna útil à propaganda e autoafirmação nacional.

Denaldo Alchorne de Souza diz ainda que, até 1930, as autoridades políticas tinham interesse no futebol, mas o tratavam "de forma esparsa, desorganizada, sem um

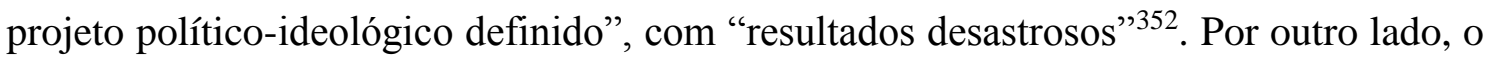
mesmo historiador traz Hobsbawm para a conversa e nos mostra que "a imaginária comunidade de milhões parece mais real na forma de um time de onze pessoas (...) o indivíduo, mesmo aquele que apenas torce, torna-se o próprio símbolo de sua nação" 353 . Por saber disso, o Estado Novo se envolve na organização da seleção brasileira para a Copa de 1938, o que colaborou para os bons resultados em campo. Foi nesta competição que o Brasil conseguiu seu melhor resultado em Copas do Mundo até então e acabou por consolidar certas construções do varguismo. É o que veremos a seguir.

\subsubsection{A copa de 1938}

O embate entre amadorismo e profissionalismo, representado neste capítulo por Salathiel de Campos e Thomaz Mazzoni, respectivamente, se desenrolava, em nível mundial, na disputa entre o International Olympic Committee (IOC, ou COI, em português) e a Fédération Internationale de Football Association (FIFA). Essa queda de

\footnotetext{
${ }^{351}$ CAPANEMA, Gustavo IN DE SOUZA, Denaldo Alchorne. O Brasil entra em campo, Construções e reconstruções da identidade nacional (1930-1947). São Paulo: Annablume, 2008. Pag 93.

352 DE SOUZA, Denaldo Alchorne. O Brasil entra em campo, Construções e reconstruções da identidade nacional (1930-1947). São Paulo: Annablume, 2008. Pag 36.

353 HOBSBAWM, Eric, 1990, pag 171 IN SOUZA, Denaldo Alchorne. O Brasil entra em campo, Construções e reconstruções da identidade nacional (1930-1947). São Paulo: Annablume, 2008. Pag 37.
} 
braço foi mais profundamente estudada por Sérgio Settani Giglio em seu doutorado COI x FIFA: a história política do futebol nos jogos olímpicos ${ }^{354}$.

A presença ou ausência do futebol nos Jogos Olímpicos da Era Moderna foi sempre um reflexo da aceitação (ou não) de atletas não amadores. Credita-se a essa disputa a criação, em 1930, da Copa do Mundo de Futebol, competição para os profissionais, enquanto as Olimpíadas seguiriam com os amadores.

Sérgio Giglio aponta um dos principais impasses: o recebimento de dinheiro por tempo de afastamento. Se era necessário ser amador para disputar as Olimpíadas, todos os atletas que não viviam de rendas vultosas, como os mais ricos, tinham um emprego e, já que precisavam se ausentar para disputar as competições, tinham descontado o tempo fora do serviço em seus salários. Para resolver a questão, pagava-se pelo tempo em que o atleta amador ficava fora de suas funções. A FIFA defendia esse modelo, o COI, era contra $^{355}$. Após o futebol ter ficado de fora da Olimpíada de 1932, mas ter tido um grande sucesso com a Copa de 1934 (a segunda edição), a FIFA aceitou as condições do COI para a Olimpíada de 1936.

Assim, a Copa de 1938 teve importância por ser um dos principais eventos a consolidar o poder da FIFA sobre o futebol - a última antes do início da Segunda Guerra Mundial, que iria paralisar tanto as Copas quanto as Olimpíadas por mais de uma década. Segundo Sérgio Giglio:

"Ao longo de vários anos não houve nenhuma
transformação significativa em relação aos dilemas entre
amadorismo e profissionalismo. Eles estavam presentes e
operavam em relação às decisões do COI e da FIFA. O
que estava por trás de todo esse debate era a busca pelo
controle das ações referentes aos atletas, gato que
concederia à entidade que estabelecesse as regras uma
condição de poder no cenário esportivo internacional" 356

Salathiel de Campos, um militante do movimento negro e defensor do amadorismo, acompanharia ainda a Copa de 1950, na qual a FIFA, profissionalista, conquista de vez essa "condição de poder no cenário esportivo internacional" (no que

\footnotetext{
${ }^{354}$ GIGLIO, Sérgio Settani. COI x FIFA: a história política do futebol nos jogos olímpicos. 2013. Tese (Doutorado em Pedagogia do Movimento Humano) - Escola de Educação Física e Esporte, Universidade de São Paulo, São Paulo, 2013. doi:10.11606/T.39.2013.tde-21012014-133735. Acesso em: 2017-11-13. 355 Idem. Pag 475.

${ }^{356}$ Idem, pag 194-195.
} 
tange ao futebol) e os atletas negros são escolhidos por agentes racistas como os culpados pela derrota do Brasil contra o Uruguai. Uma dupla decepção.

Mas, voltando à Copa de 1938, Salathiel de Campos teria razões para ficar satisfeito:

\section{"A estréa do seleccionado brasileiro no Campeonato Mundial foi a sansação do momento. Monopolizou a attenção nacional, em todas as camadas sociaes. \\ Á hora determinada, todos synthonizaram os apparelhos para a 'Cruzeiro do Sul', em meio da mais profunda emoção." 357}

O comentário dele a respeito da partida também pode ser relacionado ao conceito de forma-representação, trabalhado por Luiz Henrique de Toledo, que expusemos aqui ${ }^{358}$. Campos disse que, na Europa, "o aspecto physico do jogador se relaciona muito de perto com a technica" e que "fiel aos regulamentos e observando os costumes, o jogador europeu põe em prática (...) o esforço physico de trancos e marretas" e "tira o melhor proveito de seu preparo physico". Acrescentou, inclusive, o fator da interpretação das regras, que faz parte do conceito trabalhado por Toledo, quando disse que "não raro os sul-americanos que excursionaram pela Europa se queixam da rigorosidade dos arbitros europeus e do modo bastante violento como se conduzem os jogadores locaes".

Se Salathiel de Campos, ao descrever o futebol de Tatú e, especialmente, Petronilho de Brito, elencou características marcantes da forma-representação chamada de "escola brasileira" - para Salathiel, "escola paulista" - e, mais tarde, "futebol-arte", nessa coluna de 1938 ele descreveu a forma-representação europeia: o "futebol-força". A essa altura, levou em conta também a interpretação das regras, fechando assim a tríade deste conceito: "as regras, as formas de jogo-esquemas táticos - e representações sobre o futebol condensadas nas chamadas escolas: arte, força”. ${ }^{359}$ Partindo daí, afirmou que as características do futebol brasileiro eram diferentes daquelas. Era um "bailado choreograpfico, rico de improvizações momentaneas" 360 .

\footnotetext{
357 Correio Paulistano, Todos os Esportes, Ao Correr da Penna, 06-06-1938, pg.10, primeira coluna. Disponível em <http://hemerotecadigital.bn.br/acervo-digital/> acesso em 08/11/2015.

358 TOLEDO, Luiz Henrique de. Lógicas no Futebol. São Paulo: Hucitec/Fapesp, 2002.

359 Idem.

${ }^{360}$ Correio Paulistano, Todos os Esportes, Ao Correr da Penna, 06-06-1938, pg.10, primeira coluna. Disponível em <http://hemerotecadigital.bn.br/acervo-digital/> acesso em 08/11/2015.
} 
O texto Football Mulato, de Gilberto Freyre, publicado no jornal Diário de Pernambuco e já citado aqui, seria publicado apenas dez dias depois. E é flagrante a semelhança entre o que escreveu o jornalista paulista e o que escreveu o sociólogo pernambucano, como podemos observar no seguinte trecho:

"Os nossos passes, os nossos pitu's, os nossos
despistamentos, os nossos floreios com a bola, e alguma
coisa de dansa e de capoeiragem que marca o estylo
brasileiro de jogar foot-ball." 361

Freyre utilizaria duas categorias, que tomou emprestadas do filósofo alemão Friedrich Nietzsche e do também alemão, Oswald Spengler: apolíneo e dionisíaco.

"Porque é um mulatismo, o nosso-psy-chologicamente,
ser brasileiro é ser mulato - inimigo do formalismo
apollineo - para usarmos com alguma pedanteria a
classificação de Spengler - e dyonisiaco a seu geito - o
grande geitão mulato"362

Não parece forçado aplicar essas categorias ao texto de Salathiel de Campos. Tratando-se do mesmo discurso, a única diferença do sociólogo pernambucano para o jornalista paulista é que o primeiro capricha em neologismos que reforçam a argumentação (mulatismo) e cita referências eruditas, como acadêmico que era (citação a Spengler e utilização de conceitos filosóficos).

Apesar de Salathiel de Campos ter sido, a princípio, um grande interessado em apontar a questão racial como centro do futebol praticado pelos brasileiros, devemos lembrar que os jogadores negros que se destacavam naquela seleção eram os cariocas Domingos da Guia e Leônidas da Silva. Apenas cinco paulistas integraram aquela seleção: Euclydes Barbosa (Corinthians), Argemiro Pinheiro da Silva (Portuguesa Santista), José Augusto Brandão (Corinthians), José dos Santos Lopes (Corinthians), Luís Mesquita de Oliveira (Palestra Itália, atual Palmeiras), dos quais apenas os três primeiros eram negros, e nenhum deles se destacou tanto quanto os cariocas - ampla maioria no elenco.

Salathiel de Campos cita, isso sim, a campanha do Paulistano pela Europa, que ocorrera em 1925 e que seria descrita mais tarde por Araken Patuska no livro Os Reis do

361 Diário de Pernambuco, Football Mulato. 17/06/1938.

362 Idem. 
Futebol $^{363}$. Em sua coluna, o jornalista diz que "já havia chegado ao distante paiz norte europeu a fama dos jogadores da terra do Cruzeiro do Sul, envolvida numa aureola lendaria que a actuação formidavel da estupenda excursão do Paulistano creára" ${ }^{364}$. Tendo o Brasil ganhado da Polônia, no primeiro jogo, por 6 a 5, com três gols da estrela do time, Leônidas da Silva, Salathiel afirma que "viu o grande arqueiro polonez que as noticias lendarias eram uma authentica realidade" 365

Sobre Leônidas, "o homem diabolico que se postara á frente da méta de modo ameaçador", disse que o jogador criou uma nova lenda ao jogar descalço "como se estivesse, indumentariamente, egual aos demais jogadores". E aí está "uma lenda que, certamente, correrá o mundo esportivo da Polonia" e "jamais a figura diabolica de Leonidas sahirá da imaginação creadora de Madejeswky, que terá, ainda, muitas noites de insonia"366. O fato do craque ser negro e demonstrar habilidades superiores era irrestível a Salathiel de Campos. A essa altura, talvez contaminado pelo clima nacionalista de uma Copa do Mundo, e mais ainda pelo bom desempenho da seleção brasileira, se mostra menos paulista e mais brasileiro.

Com metáforas e viés poético, Salathiel descreve uma grande mobilização em torno do jogo contra a Tchecoslováquia. Um texto que, na chave da crônica, não fica nada atrás dos textos mais conhecidos de Mario Filho e Nelson Rodrigues, os irmãos que são mais costumeiramente lembrados como grandes intérpretes, em crônicas bem escritas e envolventes, da dramatização do futebol brasileiro. Salathiel de Campos diz:

\footnotetext{
"O mar immenso e caprichoso é bem a esphinge que desafia o genio humano através de suas invenções.

(...)

A alma humana é bem um mar immenso, capricho e incompreensivel...

Ha um mundo incalculável de emoções no recondito da alma, prompto a uma explosão immediata ao contacto de uma faisca provocadora das paixões.
}

\footnotetext{
363 PATUSKA, A. Os reis do futebol. São Paulo: Bentivegna, 1976.

${ }^{364}$ Correio Paulistano, Todos os Esportes, Ao Correr da Penna, 09-06-1938, pg.10, primeira coluna.

Disponível em <http://hemerotecadigital.bn.br/acervo-digital/> acesso em 08/11/2015

365 Idem.

366 Idem, ibidem.
} 
Quasi sempre, dentro da mascara facial reservada se occulta uma luta terrivel de controle dos nervos em marcha para uma explosão.

(...)

Porque, ha sentimentos e tendencias que nem sempre podem estar ao livre arbitrio de si mesmas.

(...)

Mas, ha momentos em que nem todas as forças conjugadas conseguem deter a marcha explosiva das paixões e o sub-consciente, do bem ou do mal, se manifesta em toda a plenitude.

Foi um desses momentos que se registou hontem, nesta capital ao ouvirmos a voz do "speaker" annunciar o encerramento da luta de Bordéos, entre o Brasil e a Tchecoslovaquia.

E descreve esse gatilho que dispara o ufanismo que é uma Copa do Mundo, tão familiar quem o lê nos dias de hoje. A cena descreve muito bem o que é o Brasil atual durante essa competição ou, pelo menos, o que a maior parte dos brasileiros acredita ser a cena geral:

"A cidade, tão tumultuosa e barulhenta, apresentava um aspecto interessante. Como por encanto, cessou toda a movimentação, formando pequenos grupos á frente das casas possuidoras de radio, como oasis agrupados nos labyrinthos das cidades do deserto.

(...)

Como o mar, explosivo e indomito, a turma não pode mais conter as explosões d'alma e sahiu para as ruas, carregando em triumpho a bandeira nacional, ovacionando os nossos campeões e acclamando o Brasil.

(...)

Scenas frisantes de brasilidade, como uma demonstração de que, no sub-consciente de cada um de nós, existe, inflammado e firme, o ideal de nacionalidade. "367

Novamente, vemos Salathiel de Campos acionando muito mais o seu nacionalismo do que o seu bandeirantismo. Enxerga nos brasileiros um ideal inflamado

367 Correio Paulistano, Todos os Esportes, Ao Correr da Penna, 15-06-1938, pg.10, primeira coluna. Disponível em <http://hemerotecadigital.bn.br/acervo-digital/> acesso em 08/11/2015 
e firme de nacionalidade. Na coluna seguinte, como quem contemporiza, diz que o "povo é uma criança grande, facilmente enthusiasmavel, especialmente quando lhe tocam as cordas sensiveis do coração" 368 . Esses toques nas cordas do coração eram dados pela "vida esportiva", na qual "o Brasil tem tido as jornadas mais memoraveis", que despertam "em todas nossas consciencias, servindo de traço de união entre todos nós, de todas as categorias sociaes ou condições economicas" ${ }^{369}$.

O que identificamos aqui é uma visão, atualmente tão familiar quanto a cena de um dia de jogo de Copa do Mundo. O futebol como elemento congregador de classes e raças - talvez equiparado, mais recentemente, à praia e ao carnaval, espaços sobre os quais se projeta a mesma ideia de democracia social e racial. Para Salathiel de Campos, o amálgama dessa união indistinta são os vínculos nacionalistas e patrióticos.

No dia seguinte, retomando a valorização do nacional e a negação do estrangeiro, Salathiel de Campos fala sobre como o tempo é implacável, inclusive às mitologias. Segundo o jornalista, havia uma mitologia esportiva de que "tudo o que vinha do estrangeiro era para nós uma coisa phenomenal". Partindo desse fato, ele identifica aquilo que Nelson Rodrigues chamaria, anos mais tarde, de complexo de vira-lata ${ }^{370}$. Para Salathiel, éramos "café-pequeno" - o vira-lata paulista. Mas, diz ele, "a dura e chocante realidade das coisas tem o dom de despertar os individuos do somno lethargico" ${ }^{371}$.

E era exatamente isso que estava acontecendo "nestes momentos intensamente vividos do contacto esportivo com os homens de outras terras" ${ }^{\text {"372 }}$. Porém, haveria ainda o Brasil de enfrentar as "paixões mesquinhas e, mesmo criminosa do estrabismo dos juizes europeus". Trata-se do "penal, que só existiu na doentia imaginação creadora do juiz suisso Wytrich, revelou apenas a vontade geral dos arbitros europeus em desclassificar a turma brasileira, honestamente ou não". Salathiel de Campos fala do penâlti assinalado no jogo Brasil e Itália, que terminaria 2 a 1 porque Meazza aproveitou a chance e o converteu em gol.

\footnotetext{
${ }^{368}$ Correio Paulistano, Todos os Esportes, Ao Correr da Penna, 17-06-1938, pg.8, primeira coluna. Disponível em <http://hemerotecadigital.bn.br/acervo-digital/> acesso em 08/11/2015 
Em seu texto, Salathiel de Campos relembra o caso do Perú, nas Olimpíadas de Berlim, dois anos antes, prejudicado em uma competição de natação. Mesmo havendo um vídeo, que naturalmente foi exigido pelo comitê, não foi possível se fazer justiça. $\mathrm{O}$ vídeo “desappareceu mysteriosamente". ${ }^{373}$ Possivelmente, também se lembrou, apesar de não ter registrado, da terceira edição da Taça Princesa Isabel, quando após ter ganhado as duas primeiras edições, o time dos jogadores negros poderia ter posse definitiva da taça caso ganhasse novamente, mas, neste último jogo, um pênalti inexistente foi marcado em favor do time dos jogadores brancos, deixando o jogo empatado.

Salathiel de Campos chega a citar, para elogiar, o protesto do delegado sueco, na Comissão Organizadora daquela Copa do Mundo, "que teve a coragem de dizer, alto e bom som, o esbulho soffrido pelo Brasil e exigir a reforma radical dos organismos da FIFA para que o mundo não tivesse mais actos immoraes como aquelle" que só serviram, segundo o jornalista, para desmoralizar os dirigentes e enfraquecer o laço fraternal do esporte, que deve unir, indistinctamente, homens de todas as raças e castas" 374 .

Um erro de arbitragem- proposital, na visão de Salathiel de Campos - tira o time da final da Copa do Mundo de 1938. A seleção que tinha como craques "elementos essencialmente nacionais", como disse Salathiel de Campos sobre os homens negros, notadamente Domingos da Guia e Leônidas da Silva, além de outros tantos atletas negros, três deles paulistas. Apesar do "profundo abysmo que desafia a sua tenacidade", o Brasil ganha a disputa de terceiro lugar contra a Suécia por 4 a 2, com dois gols do Diamante Negro, como Leônidas era chamado. O primeiro veio para empatar, o segundo, para virar o placar. Perácio ainda ampliaria a contagem.

Na final, a seleção da Itália seria a campeã, após uma vitória por 4 a 2 contra a Hungria. A Itália de Mussolini, estudada por Gilberto Agostino em seu livro Vencer ou Morrer. ${ }^{375}$ Este autor mostra que, estimulados pelo regime fascista, bons jogadores sulamericanos de origem italiana, os oriundi, foram naturalizados e ajudaram a seleção na Copa do Mundo (na de 1938 como na de 1934). A frase "vencer ou morrer", que dá título

\footnotetext{
${ }^{373}$ Correio Paulistano, Todos os Esportes, Ao Correr da Penna, 18-06-1938, pg.8, primeira coluna. Disponível em <http://hemerotecadigital.bn.br/acervo-digital/> acesso em 08/11/2015

${ }^{374}$ Correio Paulistano, Todos os Esportes, Ao Correr da Penna, 25-06-1938, pg.8, primeira coluna. Disponível em <http://hemerotecadigital.bn.br/acervo-digital/> acesso em 08/11/2015 ${ }^{375}$ AGOSTINO, G., Vencer ou morrer. Futebol, geopolítica e identidade nacional. Rio de Janeiro, Faperj/Mauad, 2002.
} 
ao livro de Agostino, é justamente do duce, que a escreveu em mensagens pouco sutis enviadas aos jogadores na já citada final contra a Hungria ${ }^{376}$.

Esse controle estatal do esporte italiano, que sagrara-se bicampeão consecutivo da Copa do Mundo, possivelmente estava vivo, como ideia, quando Salathiel de Campos assiste a uma parada em homenagem a Vargas, o que o leva a dizer em sua coluna:

"O esporte é, nos tempos que correm, funcção obrigatoria do Estado. Assim o compreenderam varios paizes, que intervieram franca $e$ directamennte em suas actividades.

(...)

Realmente, o espirito esportivo faz despertar no individuo todo o ardor patriotico, como temos visto por diversas vezes.

(...)

Ao contrario do que se pretendeu crer, o esporte não é adversario do espirtio e da cultura. Justamente ao contrario.

Ainda domingo nos vieram á mente essas considerações, ante o impressionante desfile da mocidade escolar e esportiva deante do sr. Presidente da Republica.

$O$ ar marcial e solenne dos componentes dos batahlóes escolares se casava com a alacridade e porte majestoso dos quadros esportivos ali presentes.

E ficamos a pensar que se houvesse uma intervenção racional do Estado na vida esportiva do paiz, acabando com as questiunculas $e$ aparando os golpes clubisticos que o prejudicam, teriamos, certamente, prestado um optimo serviço ao paiz. "377

A liberdade de livre organização federalista, transmitida também para o esporte, que Thomaz Mazzoni chamou de "bairrismo", já não aparece mais nos textos de Salathiel de Campos. Em 1938, já não há mais Movimento Pátria Nova, nem Frente Negra Brasileira ou o Clube Negro de Cultura Social.

\footnotetext{
376 Idem.

377 Correio Paulistano, Todos os Esportes, Ao Correr da Penna, 26-06-1938, pg.8, primeira coluna. Disponível em <http://hemerotecadigital.bn.br/acervo-digital/> acesso em 08/11/2015
} 
A carreira de Salathiel de Campos ia bem, e estava em ascensão, mas todos os seus espaços de mobilização prática foram fechados e proibidos. Em suas páginas, o discurso militante da causa negra brasileira arrefece. Há espaço para o jornalista nacionalista, especialista em futebol, que exalta o suposto estilo brasileiro de jogar futebol, que diz ser este esporte uma demonstração de que não somos "café-pequeno", que reclama em suas colunas dos erros de arbitragem estrangeiros que prejudicaram a seleção nacional, que fala em patriotismo, reuniões fraternais e que diz ser "somente num ambiente de paz que se póde trabalhar para o progresso"378.

Quando fala em raça, o faz superficialmente ou lembrando de casos antigos, quando fala do ano de 1926, importantíssimo em sua carreira, e da experiência que, naquela época, teve no São Paulo Jornal, adjetiva esse momento como "estuante e ideológico" 379 . Em seus textos, passa a ser mais brasileiro que paulista, e fala, por exemplo, da relação esportiva entre o Brasil e outros países sul-americanos, lembrando do "conceito de Monroe: A America para os Americanos". ${ }^{380}$ Reclama do silêncio da torcida, já que "raramente, se ouvem através dos campos, os 'hurras' incentivadores”.381 Critica o "Campeonato Brasileiro de Futebol", que "perdeu a sua razão de ser"382. Não muito mais do que isso. Assuntos triviais para uma coluna de jornal esportiva.

\subsection{O fim}

Os movimentos sociais e partidos foram proibidos, o Clube Negro de Cultura Social fechado, seus textos sobre a questão racial iam desaparecendo e, em pouco tempo, Salathiel de Campos também sairia de cena. Um fim melancólico e trágico, bastante simbólico se pensarmos no que foi a sua trajetória de lutas: sempre golpeadas, limitadas, como ele disse, por um "abysmo".

Salathiel de Campos publica sua coluna até 1939 e, por alguma razão que não conhecemos, deixa de aparecer nos jornais paulistas e passa a publica-la, com o mesmo

\footnotetext{
${ }^{378}$ Correio Paulistano, Todos os Esportes, Ao Correr da Penna, 28-06-1938, pg.12, primeira coluna. Disponível em <http://hemerotecadigital.bn.br/acervo-digital/> acesso em 08/11/201

379 Correio Paulistano, Todos os Esportes, Ao Correr da Penna, 14-08-1938, pg.14, primeira coluna. Disponível em <http://hemerotecadigital.bn.br/acervo-digital/> acesso em 08/11/201

380 Correio Paulistano, Todos os Esportes, Ao Correr da Penna, 19-10-1938, pg.8, primeira coluna. Disponível em <http://hemerotecadigital.bn.br/acervo-digital/> acesso em 08/11/201

${ }^{381}$ Correio Paulistano, Todos os Esportes, Ao Correr da Penna, 08-12-1938, pg.14, primeira coluna. Disponível em <http://hemerotecadigital.bn.br/acervo-digital/> acesso em 08/11/201

${ }^{382}$ Correio Paulistano, Todos os Esportes, Ao Correr da Penna, 14-12-1938, pg.8, primeira coluna. Disponível em <http://hemerotecadigital.bn.br/acervo-digital/> acesso em 08/11/201
} 
nome, em um jornal de Joinville: A Noticia. É possível, mas não muito provável, que ele tenha passado um ano naquela cidade. Nessas publicações, volta a falar em "nacionalização do esportiva":

"Nacionalizar em todos os sentidos, desde a fiscalização dos corpos sociaes até as finalidades declaradas ou apparentes das varias sociedades que surgiram nos meios brasileiros com prolongamentos de associações secretas ou disfarçadas de entidades além mar. "'383

E compara Rui Barbosa a Friedenreich:

“(...)tivemos duas figuras realmente populares nos circulos geraes do paiz e até hoje não foram ultrapassadas: Ruy e Friedenreich.

O grande Ruy, num tumultuar de paixões politicas que dominava a época, palmilhou o paiz de norte a sul, como candidato á curul presidencial e o povo em geral o recebeu em apotheoses expressivas.

Mais modesto e sem ambições, o nosso Friedenreich passeou pelos quadrantes do paiz, exhibindo o alto padrão de sua classe inatingivel, que lhe valeu o titulo de "Primus inter pares". Nunca lhe passára pelo pensamento transformar em cifras essa popularidade e estima dos seus compatriotas. Tendencia activa do brasileiro.

Testemunhas de varios episodios interessantes $e$ expressivos da vida de Fried, preferimos um que nos contára, emocionado, o grande artista da pelota. "384

Retorna ao Correio Paulistano em 1941 - o que possivelmente também significa um retorno a São Paulo, caso tenha passado um ano fora. Sua coluna, Ao Correr da Penna, continua ativa como antes, agora com um melhor acabamento visual, e com títulos específicos para cada texto. Ele segue como chefe da redação esportiva até que, em 16 janeiro de 1945, às 14 horas daquele dia, Salathiel foi abordado por Antonio Almeida Soares, o boxer português que, indignado com uma coluna que o havia criticado, agrediu o jornalista, causando sequelas que o fariam ter quatro acidentes vasculares cerebrais até morrer em 1951.

\footnotetext{
383 A Notícia, Ao Correr da Penna. Joinville: 06/02/1940, pag 4.

${ }^{384}$ A Notícia, Ao Correr da Penna. Joinville: 10/03/1940, pag 8. Grifos nossos.
} 
Nos anos seguintes, Salathiel de Campos é efetivado como redator do Diário Oficial, depois tenta pedir uma aposentaria por este serviço e por outro, em um cartório, onde deve ter trabalhado quando adolescente. Buscava alguma condição financeira, já que estava cada vez mais afastado dos trabalhos, entre uma licença médica e outra. Participou, ainda, do que houve de mobilização do movimento negro após a derrubada de Vargas em fins de 1945, como também já vimos.

A história dramática de Salathiel de Campos ainda passaria pelo perdão a seu agressor e pela derrota brasileira no Maracanã contra os uruguaios na Copa do Mundo de 1950. Ele que lutara pela inclusão de negros no futebol brasileiro viu a pior derrota do país até então ser atribuída a esses atletas, especialmente os que atuavam da defesa.

Possivelmente, percebeu que a simples inclusão de atletas negros em times de futebol, ainda que momentaneamente se tornem ídolos, não acaba com o racismo nem com o preconceito. É uma integração frágil, e útil: contando com a ajuda de talentosos jogadores negros, o time pode ganhar e tudo estará bem, eles terão sido úteis ao espetáculo; em caso de derrota, já há uma culpa a ser formada e um culpado a ser apontado. As interrupções pelas quais o movimento negro passou fizeram com que a luta imprescindível fosse atrasada e limitada.

Com a morte de Salathiel de Campos em dezembro de 1951, houve uma certa comoção, porém menor do que seis anos antes, quando fora agredido. Em 1952, Miguel Sansigolo, um vereador do Partido Social Progressista, de Ademar de Barros, tem deferido um projeto para homenagear Salathiel de Campos dando seu nome a uma rua no bairro dos Pinheiros. Não com o objetivo de "tão somente render culto à memória de um jornalista" mas também de homenagear "à nossa terra e à imprensa esclarecida e bem orientada" ${ }^{385}$. A determinação do bairro desaparece dos documentos, e passa a ser, genericamente, "uma das ruas da capital". O que encontramos, ao menos atualmente, é uma rua chamada Salatiel de Campos (assim, sem a letra $\mathrm{H}$ ) no Jaguaré.

O Diário da Noite, do Rio de Janeiro, comenta brevemente a situação do pugilista agressor:

"Antonio Soares anda por São Paulo, sempre trapalhão, ás voltas com bolsas suspensas, por 'tongo' e com a

${ }^{385}$ SÃO PAULO, Diário Oficial, Requerimento no 1074.52, 15 de setembro de 1952. pag.52. 
polícia, pois agrediu o nosso colega Salatiel [sic] de Campos, o qual jámais teve saude e andou muito mal. ${ }^{\text {"386 }}$

Em março de 1954, o Jornal do Brasil, do Rio de Janeiro, e a Gazeta de Notícias, de São Paulo, anunciam um concurso comemorativo do $60^{\circ}$ aniversário da introdução do futebol em São Paulo. Para a data estar correta, os organizadores concordam com a ideia de que o marco inicial deste esporte, neste estado, é a chegada de volta da Europa de Charles Miller - que aconteceu em 1854.

Organizado pela Federação Paulista de Futebol, o chamado "Concurso Literário" iria avaliar trabalhos escritos a respeito do futebol paulista. Os temas definidos foram: Evolução do Futebol em São Paulo e Função Social do futebol. Para cada tema, foram definidos três prêmios. Salathiel de Campos foi o nome dado ao prêmio de melhor trabalho sobre a função social do futebol. Eis os prêmios:

$$
\begin{aligned}
& \text { "Evolução do futebol: } \\
& 1^{o} \text { prêmio - Mario Cardin Cr } \$ 20.000,00 \\
& 2^{\circ} \text { prêmio - Jadir Gomes Cr } \$ 10.000,00 \\
& 3^{o} \text { prêmio - Mario de Macedo Cr } \$ 5.000,00 \\
& \text { Função social do futebol: } \\
& 1^{\circ} \text { prêmio - Salathiel de Campos Cr } \$ 20.000,00 \\
& 2^{\circ} \text { prêmio - Antônio Figueiredo Cr } \$ 10.000,00 \\
& 3^{\circ} \text { prêmio - Plinio Clasca Cr } \$ 5.000,00 ", 387
\end{aligned}
$$

Essa homenagem fica como um réquiem para o jornalista. Seu nome, dessa data em diante, começa a desaparecer. Aproveitando essa deixa, tentaremos agora responder a última questão proposta no início desse trabalho. Quais a causas do esquecimento de Salathiel de Campos por seus contemporâneos e, por consequência, pelos que vieram depois?

Sabemos que o esquecimento, assim como a lembrança, faz é. também um indício, é uma pista, faz parte do paradigma indiciário da História, como demonstrado por Ginzburg ${ }^{388}$. E, por sabê-lo, estudar o esquecimento de Salathiel de Campos é conhecer

\footnotetext{
${ }^{386}$ Diario da Noite, Rio de Janeiro, 12/03/1952, pag 6, segunda coluna.

387 Jornal do Brasil, Coluna de Esportes. 07/03/1954.

388 GINZBURG, Carlo. Sinais: raízes do paradigma indiciário. IN: Mitos, Emblemas e Sinais. São Paulo: Cia das Letras, 1990. Pag 143.
} 
melhor a sua época e, por extensão, as que se seguiram. Sabendo que essa questão merece ainda uma pesquisa própria e dedicada, oferecemos algumas explicações.

Após o fechamento político do Estado Novo (1937), o movimento negro demorou a ser o que foi com a Frente Negra Brasileira, passa por dificuldades de mobilização e de reorganização. Apesar de voltar com força após 1945, enfrentou ainda uma outra ditadura (1964-1985). Com essas pausas forçadas, há rachaduras. O movimento pós-45 não é, certa e obviamente, o mesmo do início da Era Vargas. Então, no campo político o nome de Salathiel de Campos também desaparece. O que poderia ser um meio de resgatá-lo, uma volta ao passado que buscasse os primeiros grandes nomes da militância, foi na verdade - por fatores externos, que fique claro - mais uma razão de seu esquecimento.

No campo esportivo, nenhum dos autores mais conhecidos e consagrados, contemporâneos a ele, o citaram. Gilberto Freyre, que em sua coluna Football Mulato (de 1938), como vimos aqui repete as ideias que Salathiel de Campos escrevera dez dias antes - ou mesmo quatro anos antes se considerarmos o $O H N E B$ - não o cita. Podemos supor que, apesar dessa aproximação teórica a respeito da raça e do futebol, não o tenha lido. Mas também o ítalo-brasileiro Thomaz Mazzoni, que publicou seu livro História do Football em abril de 1950, e certamente conhecia o trabalho de Salathiel de Campos, não o cita. Nem o pernambucano radicado no Rio de Janeiro Mário Filho, que publicou $O$ Negro no Futebol Brasileiro em 1947 e 1964. Nem o santista Araken Patuska, que publicou Os Reis do Futebol em $1945^{389}$. Não há citações a qualquer obra de Salathiel de Campos como fonte, apesar de dificilmente ele não ter sido lido por pelo menos um desses autores. Mazzoni, por exemplo, cita em seu livro (1950) a história de David, negado pelo Corinthians por ser negro. História essa que, como vimos, foi narrada por Campos dezesseis anos antes (item 1.3.) ${ }^{390}$.

Isso se deve - talvez não completamente, mas em parte - ao lugar de onde Salathiel de Campos falava. Esse é um dado importantíssimo para entender o seu esquecimento. Negro, caipira, de origem pobre, militante do movimento negro e do patrianovismo, e além de tudo um bandeirantista. Diferente de Mazzoni, Mário Filho e Gilberto Freyre, não estava em uma posição hegemônica.

\footnotetext{
389 Há uma segunda edição de 1976.

${ }^{390}$ Agradeço a José Paulo Florenzano por ter chamado a minha atenção para esta (falta de) referência de Mazzoni.
} 
Dos citados acima, Thomaz Mazzoni e Mário Filho eram essencialmente nacionais, e não locais. Em termos de estilo, Mazzoni se restringia ao esporte, Mário Filho o extrapolava mas com um tom bastante anedótico, bem humorado e conciliador. Salathiel de Campos, por outro lado, era contestador, indignado, politizado...era um incômodo. Em um momento de construção de uma ideia de Brasil, de construção da ideia hegemônica do que seria este país, este jornalista militante jamais deixou de incluir o racismo. Para ele, a questão racial, centrada no preconceito e não na conciliação, deveria fazer parte de qualquer ideia de Brasil que fosse construída.

Ao longo de sua carreira, o darwinismo social e a eugenia ficaram distantes, mas ainda vivos. E o que se aproximava com uma força tremenda era a ideia de democracia racial. A sua ideia de Brasil foi, em parte, consolidada pelo Estado Novo: o esporte e o samba (essencialmente brasileiro por contar fortemente com o elemento negro) com conotações patrióticas - a seleção de 1938, o futebol como símbolo da nação, o esporte amador como formador de cidadãos, o samba exaltação que engrandecia as (supostas) qualidades do país; um Estado forte e presente; a valorização do brasileiro em detrimento do estrangeiro, etc. Mas, ao fim e ao cabo, se sobrepôs ao racismo como elemento formador do Brasil (que ele enxergava) o mito da democracia racial. No Brasil varguista não havia espaço para debater racismo, posto que (supostamente) vivíamos no paraíso das raças.

Mazzoni abraçou esse discurso, assim como Mário Filho depois dele. A questão racial como Salathiel de Campos a propunha deixou (por um bom tempo) de estampar as páginas dos jornais de grandes circulação. Após este breve período que estudamos, ficou restrita à sociologia ou à estetização das artes ${ }^{391}$.

Por tudo que foi exposto, Salathiel de Campos ficou esquecido pela história. Quando Joel Rufino dos Santos, autor negro que escreveu a História Política do Futebol Brasileiro, a quem este trabalho deve muito, Salathiel de Campos já não fazia mais parte da narrativa e, não tendo acesso às fontes, não pode fazer parte desse importante estudo a respeito do esporte no país.

Salathiel de Campos foi chefe de redação em pelo menos três jornais, trabalhou no Diário Oficial, publicou livros, foi homenageado inúmeras vezes pela sociedade

\footnotetext{
391 Devo agradecer a Luiz Henrique de Toledo por esta análise sobre o destino do tema "racismo" após o período histórico que encerra este trabalho.
} 
paulistana - em vida e após sua morte . Era alguém que fazia parte da modernidade negra da cidade de São Paulo, junto de Celisa Vieira, com quem formou uma família de classe média dos anos vinte até o início dos anos cinquenta. Seu filho, Pedro Paulo, como mostra o Diário Oficial, casou-se com Emelia Cosmo de Oliveira em 20 de dezembro 1974, próximo ao aniversário de morte do pai. Ele, porteiro, e ela, empregada doméstica, ambos residentes no bairro da Saúde. Duas profissões dignas, isso é certo, mas algo significativas se as compararmos com a condição financeira e a projeção social que o pai alcançara em vida.

A história de Pedro Paulo demonstra a fragilidade da integração da população negra neste período que foi estudado. Um negro até pôde chegar a ter a importância que teve Salathiel de Campos, mas uma agressão covarde acabou com sua saúde, o matou, deixou sua família exposta a condições financeiras bem piores do que tinham, e o capital financeiro e social acumulado por Salathiel de Campos ficaram restritos a ele e ao seu próprio tempo de vida.

Enquanto isso, havia cada vez mais jogadores negros no futebol paulista e brasileiro, uma conquista da qual ele participou ativamente. Mas parou por ai. A presença de ídolos negros na música e no esporte, ou a presença de negros como operários do espetáculo, foi o máximo que se conquistou. Nada disso significou uma inclusão mais ampla e bem consolidada da população negra no Brasil. O trabalhou ficou incompleto. Ainda há muito por fazer. 


\section{Conclusão}

O futebol paulista, ao menos o chamado "futebol oficial", enquanto amador, era um hobby da elite e um espaço de sociabilidade das novas gerações das famílias ricas, brasileiras ou imigrantes. Era nesse futebol que o movimento negro, pela agência de Salathiel de Campos, queria uma entrada.

Fazia parte de seu desejo e da sua luta aceitar o estado de coisas, em certa medida. Admirava o cavalheirismo dos sportsmen da elite, suas qualidades intelectuais, educacionais e, especialmente, morais. Era nesse círculo que Salathiel de Campos gostaria de ver os negros, totalmente integrados ao grupo. Gostaria que os negros ocupassem posições de comando, como treinadores ou dirigentes de clube. Cargos, aliás, que até hoje têm uma sub-representação da população negra. Ainda, como no tempo de Salathiel de Campos, no futebol, a presença de negros em posições de comando está restrita à varzea.

Como disse o jornalista: "O futebol era um elo a prender todos os componentes dessas associações: era apenas o motivo, por ser uma diversão popularíssima, como o poderia ser o baile ou a literatura", e quando "foi considerado, annos depois, um pretexto já pernicioso a um meio social de certa cultura" os clubes mudaram seus rumos. Entre "a continuação do clube como associação futebolística ou gremio social, onde os dotes de instrucção, educação e recreativos imperassem, preferiram esta ultima qualidade, abandonando a pratica do futebol" ${ }^{392}$. Saíram da posição de atletas, pararam de suar, e passaram à condição de espectadores.

Nesse momento, o profissionalismo avança e as conquistas do movimento negro já surtiam seus efeitos. Havia negros nos clubes da Primeira Divisão, negros nas seleções estaduais e nacionais - apenas como jogadores, mas havia. A integração conquistada, porém, se deu no futebol profissional. Não naquele futebol que dividia espaço com uma convivência social de elite, não no esporte que era um elo a prender os membros do clube, não no espaço de sociabilidade da elite paulistana. Aqueles que tinham habilidades comprovadas e se mostravam úteis, foram integrados a um futebol que já se consolidava como um ofício, uma profissão, numa organização voltada ao mercado.

\footnotetext{
392 Correio Paulistano, Todos os Esportes, O Homem Negro no Esporte Bandeirante, 04-10-1934, pg.7, rodapé. Disponível em <http://hemerotecadigital.bn.br/acervo-digital/> acesso em 04/11/2014.
} 
Quando o futebol era fidalgo, acadêmico, elitista, a entrada aos negros era vetada - muitas vezes pelo estatuto dos clubes. Quando tornou-se um mercado, profissionalizado, foi enxergada uma utilidade a esses negros que, supostamente, tinham um talento inato para proporcionar um espetáculo - algo essencial para que fosse possível viabilizar as finanças dos clubes. Traziam consigo uma repercussão na mídia esportiva, conquistavam novos torcedores, enchiam estádios com o quê cresciam as rendas das bilheterias. Os negros entram no espetáculo, mas o fazem como funcionários, como subalternos, e só nessa condição é que são incluídos neste esporte. Justamente por isso, não foi alterada a condição dos negros na sociedade, nem ao menos a dos próprios jogadores. Passaram apenas a ser operários do espetáculo. Em campo, davam seus shows à plateia pagante. E era isso.

Um processo parecido acontece na música, especificamente o samba, que passa de proibido a exaltado, vira símbolo nacional. Da mesma forma que os negros no esporte, os negros na música são aceitos pela população branca como operários do espetáculo. $\mathrm{E}$ assim se seguem os anos. À população negra continuam reservados, de forma geral, os trabalhos braçais e subempregos, ou, para aqueles que se mostrarem capazes e talentosos, é cedido um espaço iluminado no palco do espetáculo para que sirvam enquanto, e apenas enquanto, puderem ser espetaculares. Não sem que, mesmo estando sob os holofotes, os racistas ajam para humilhá-los impunemente.

A história de Salathiel de Campos, do movimento negro em sua época, e da relação deles com o futebol, é a prova de que a representatividade, pura e simples, não causa grandes mudanças. No período estudado aqui, as rupturas, quando aconteceram, tiveram como causa, ou como uma das causas, uma mobilização social importante. O que muda a história não são alguns ídolos pinçados entre as pessoas desta ou daquela cor de pele, não são mitos como Leônidas ou Pelé. Esses agentes tem importância tremenda, não à toa Salathiel de Campos e outros intérpretes os utilizaram como símbolos. Mas isso não basta.

Estas significações, assim como o futebol de forma geral, são construídas de acordo com as disputadas pela hegemonia cultural, para utilizar o conceito de Antônio Gramsci. Cada um dos grupos dessa disputa oferece suas contribuições, busca construir suas próprias significações, mas há sempre uma contaminação (por falta de palavra melhor) entre o que se buscou construir e a construção dos outros grupos. Haja vista o mito da democracia racial, um mito sustentado, em larga medida, na contaminação do 
discursos de pessoas como Salathiel de Campos - e Gilberto Freyre depois dele - pela construção criada pelo Estado Novo varguista. Estes símbolos até podem fazer parte de um processo de mudança, mas desde que sua memória e sua história seja operacionalizada por uma mobilização social, como parte de um processo maior e mais amplo.

Como vimos, o que muda a história não são os indivíduos, mas os movimentos sociais dos quais eles participam.

\subsubsection{Pesquisas posteriores}

No presente trabalho, estas fontes inéditas foram aproveitadas na chave da mobilização política em um momento de afirmação e luta da população negra, que então vivia segregada na cidade de São Paulo, morando nos porões e impedida de entrar em certos espaços. Nosso foco, dada a natureza das fontes, foi o campo esportivo. Porém, como é natural por se tratar da primeira pesquisa dedicada a Salathiel de Campos e sua obra, ainda há muitas pesquisas a se fazer.

Cronologicamente falando, a atuação de Leopoldo Sant'Ana, antes mesmo de Salathiel de Campos se tornar um profissional de imprensa, em defesa dos jogadores de futebol negros é algo a ser estudado. As fontes para essa pesquisa podem ser encontradas na Hemeroteca Digital da Biblioteca Nacional e, parte delas, no Museu do Futebol em São Paulo.

Uma outra pesquisa a ser feita, mas cujas fontes não puderam ser rastreadas, é sobre a campanha pela convocação dos jogadores negros à seleção paulista de 1926. Estudada aqui pela primeira vez, a preocupação principal nessa campanha foi a figura de Salathiel de Campos. Sabemos, porém, que foram enviadas cartas dos leitores ao jornal A Gazeta para criticar suas ações, registros de um racismo atroz e defensor de privilégios brancos. Caso essas cartas sejam encontradas, um novo objeto de pesquisa se revela, e esta campanha, por si só, rende uma tese.

Para estudar com mais detalhes a repercussão do livro $O H N E B$, também será necessário encontrar fontes não rastreadas até agora, que por acaso também são cartas. Sabemos, nesse caso, que houve cartas elogiosas, em apoio à Salathiel de Campos, assim como algumas manifestações críticas de racistas da época. É um tema ainda por pesquisar. 
Ainda sobre este livro, fica em aberto um estudo que compare a obra ao clássico de Mario Filho, O Negro no Futebol Brasileiro. Por este último já ter sido estudado em trabalhos excelentes e importantes, por já ter merecido as análises de grandes historiadores, e por já ser largamente conhecido, privilegiamos nessa pesquisa apenas Salathiel de Campos e seu próprio trabalho. Fica por fazer, então, um trabalho que trace rupturas e continuidades entre um autor e outro.

O material escrito por Salathiel de Campos desde que se torna chefe de redação do Correio Paulistano é bastante numeroso e, por isso, abre espaço para muitas pesquisas. A coluna Ao Correr da Penna foi aqui apenas parcialmente estudada. Para o ano de 1938, por exemplo, aproveitamos apenas o período da Copa do Mundo, mas há muito ainda o que ser analisado. Da mesma forma, os anos de 1939 e 1940, que ficaram de fora deste recorte, ainda merecem atenção. Todas as colunas desse período estão disponíveis na Hemeroteca Digital da Biblioteca Nacional.

Alguns momentos da biografia de Salathiel de Campos também precisam ser melhor estudados. O presente trabalho teve a sorte de encontrar fontes importantes, como os registros do Diário Oficial, que mostraram fatos importantes da trajetória do jornalista, bastando, com isso, que o historiador cruzasse informações com outras fontes. Porém, sabemos pouco sobre sua infância no interior e pouco sobre sua vida nos anos 40 . Sobre as sequelas da agressão que sofreu e as dificuldades que enfrentou de 1945 até sua morte, em 1951, sabemos apenas o que foi exposto aqui, o que não é muito. São possíveis caminhos: a busca por fontes em Piracicaba e Salto, em cartórios, igrejas, escolas, etc., que já existissem no começo do século; a busca por documentos em hospitais do Centro, Liberdade, Vila Mariana e Saúde que já existissem em 1945, assim como fontes dos jornais onde trabalhou. Não apenas o jornal em si - especialmente a Gazeta o Correio Paulistano - mas registros, atas de reuniões, holerites, cartas, entre outras.

Após tanto tempo esquecido, ainda há muito o que se pesquisar sobre Salathiel de Campos. 


\section{ANEXO - Resultados do time dos jogadores paulistas negros ${ }^{393}$}

Data: $13 / 05 / 1927$

Local: Campo do Palmeiras

Organização: LAF

Resultado: Pretos 3 x 2 Brancos.

Time dos Pretos: Dica; Francisquinho, Ferreira; Cunha, Mono, Monti; Carrapicho, Gradin, Carmargo, Nabor, Bisoca.

Time dos Brancos: Nestor; Debbio, Clodoaldo; Raphael, Vanni, Gelindo; Apparicio, Neco, Friedenreich, Guimarães, De Maria.

\begin{tabular}{|l|}
\hline Data: 13/05/1928 \\
\hline Local: Campo do Palmeiras \\
\hline Organização: LAF \\
\hline Resultado: Pretos 4 x 2 Brancos. \\
$\begin{array}{l}\text { Time dos Pretos: Luiz Antônio; Carneiro, Musa, Rogério; Bisoca, Mono; Martins, Nabor, } \\
\text { Nhô, Pixo, Adrião }\end{array}$ \\
$\begin{array}{l}\text { Time dos Brancos: Perth; Faria, Barthô; Abbate, Gagliardo, Evers; Filó, Tedesco, Fried, } \\
\text { Armandinho, Osses. }\end{array}$ \\
\hline
\end{tabular}

\section{Data: $13 / 05 / 1929$}

Local: Campo da Floresta

Organização: LAF

Resultado: Pretos 2 x 2 Brancos.

Time dos Pretos: Dictão; Francisquinho, Ferreira, Rogério, Bisoca, Mono; Martins, Nabor, Américo, Pedrinho, Carrapicho.

Time dos Brancos: Nestor; Clodô, Nelson; Abbate, Isidoro, Munhoz; Filó, Cruz, Mathias, Krueger, Perillo.

393 Devo esta detalhada pesquisa a Denaldo Alchorne de Souza, que a levou já feita e tabelada para a banca de defesa deste mestrado e, gentilmente, a cedou para que eu disponibilizasse essas informações neste trabalho. 
Obs: Friedenreich estava selecionado para a equipe dos Brancos, mas não jogou. Em seu lugar, jogou Mathias.

Data: $13 / 05 / 1930$

Local: Campo da Floresta

Organização: C.A. Brasil

Resultado: Pretos 5 x 0 Brancos.

Time dos Pretos: Waldemar; Giby, Ferreira; Rogério, Bisoca, Mono; Martins, Vaz, Petro, Pixo, Algemiro.

Time dos Brancos: Tuffy; Vanni, Debbio; Osmar, Nerino, Ramon; Figueiredo (no $2^{\circ}$ tempo Gamba), Munhoz, Tidoca, Spitaletti, Corsatto.

Obs: Jornais como $O$ Estado de São Paulo e Correio Paulistano dão 5 x 0, Folha da Manhã e A Gazeta relatam 4 x 0. Como descobriu Denaldo Alchorne de Souza, autor dessas fichas, o jogo foi interrompido porque Munhoz atacou o árbitro e, por isso, este historiador levanta a suposição - bastante provável - de que alguns repórteres podem ter voltado às suas redações antes do fim do jogo.

Data: $13 / 05 / 1931$

Local: Campo da Floresta

Organização: C.A. Brasil

Resultado: Pretos 2 x 5 Brancos.

Time dos Pretos: Waldemar; Pedro, Ferreira; Mono, Barros, Bastos; Martins, Waldemar Brito, Francisquinho, Pixo, Evaldo.

Time dos Brancos: Halmos; Grané, Debbio; Arminana, Goliardo, Serafim; Del Pero, Luizinho, Feitiço, Barrilote, Siriri.

Data: $25 / 05 / 1932$

Local: Campo da Floresta

Organização: Frente Negra Brasileira

Resultado: Pretos 1 x 6 Brancos.

Time dos Pretos: Waldemar; Cachimbo, França; Barros, Bisoca, Raffa; Roberto, Bahianinho, Petro, Rabi, Luna.

Obs: Jogadores escolhidos por Friedenreich. 
Time dos Brancos: Moreno, Machado, Loschiav; Milton, Duilio, Tuffy; Luizinho, Armandinho, Feitiço, Araken, Vicente.

Obs: jogadores escolhidos por Armandinho

\section{Negros de São Paulo vs. Cariocas}

Data: $20 / 01 / 1929$

Local: Campo do Ipiranga

Organização: C.A. Brasil e Amea

Resultado: Pretos paulistas 6 x 2 Seleção Carioca.

Time dos Pretos paulistas: Waldemar; Giby, Ferreira, Mono, Bisoca, Rogerio, Martins, Petro, Friedenreich, Pedrinho, Picho.

Seleção Carioca: Princeza; Aragão, Nauta, Theodomiro (Jucá), Heitor (Geraldo), Nilo; Camedo (Mica), Bahiano, Amir, Bianco, Cid.

Data: $18 / 08 / 1931$

Local: Campo da Floresta

Organização: C.A. Brasil e C.A. Cordovil

Resultado: Pretos 7 x 1 Seleção Carioca.

Pretos paulistas: Waldemar; Giby, Francisquinho; Rogério, Bino, Raffa; Roberto, Bahianinho, Nabor, Rabbi, Euvaldo.

Pretos cariocas: Zezé; Domingos da Guia, Sá Pinto; Juca, Oscarino, Ferro; Canhoto, Sobral, Medio, Leonidas, Jaguarão. 


\section{Bibliografia}

\subsection{Fontes}

\subsubsection{Coletâneas de fontes}

GAMBETA, Wilson. Primeiros Passes - Documentos para a História do Futebol em São Paulo (1897-1918). São Paulo: Ludens. 2014.

BARBOSA, Márcio. Frente Negra Brasileira: depoimentos. São Paulo: Quilombhoje, 1998.

SÃO PAULO, Diário Oficial, Requerimento n ${ }^{\circ}$ 1074.52, 15 de setembro de 1952. pag.5253

\subsubsection{Jornais}

A Gazeta

A Voz da Raça

Clarim d'Alvorada

Correio da Manhã

Correio Paulistano

Folha da Manhã

Folha da Noite

Jornal dos Sports

Mundo Esportivo

O Estado de São Paulo

O Globo

\subsection{Bibliografia geral}

ADORNO, Theodor. Tempo livre. In: Indústria cultural e sociedade. São Paulo: Paz e Terra, 2002.

ALBERTI, Verena; PEREIRA, A. Araújo (orgs.). Histórias do movimento negro no Brasil. Rio de Janeiro: Pallas; CPDOC/FGV, 2007. 
ANDERSON, P. Considerações sobre o marxismo ocidental. São Paulo: Brasiliense. 1989.

ANDREWS, George. Negros e brancos em São Paulo. Bauru: EDUSC, 1998.

Democracia racial brasileira 1900-1990: um contraponto americano. In Estudos Avançados 11 (30), 1997.

. O protesto negro no Brasil 1888-1988. Estudos Afro-Asiáticos, (21);27-48, dezembro de 1991.

BALANDIER, G. Tradição e Modernidade. In: . Antropologia Política. São Paulo: EDUSP, 1969.

A desordem: elogio do movimento. Rio de Janeiro: Bertrant Brasil, 1997.

Ordem tradicional e contestação. In: Antropológicas. São Paulo Edusp/Cultrix, 1976.

BARRÈT, M. "Ideologia, política e hegemonia: de Gramsci a Laclau e Mouffe". In: ZIZEK, S. (org.). Um mapa da ideologia. Rio de Janeiro: Contraponto, 1996.

BARTHES, Roland. Semiologia e urbanismo. In: A aventura semiológica. Lisboa: Edições 70, 1985.

BLOCH, Marc. Apologia da história, ou o Ofício de historiador. Rio de Janeiro: Jorge Zahar Editor, 2001.

BOLTANSKI, L.; CHIAPELLO, E. O novo espírito do capitalismo. São Paulo: Martins Fontes, 2009.

.; THÉVENOT, L. De la justification: les économies de la grandeur. Paris: Gallimard, 1991.

BOSI, Alfredo. O tempo e os tempos. In: Novais, A. Tempo e História. São Paulo: Companhia das Letras, 1992.

BOXER, C. R. (Charles Ralph). O Império Colonial Português. Lisboa: Edições 70, 1969. 
Relações raciais no império colonial português, 1415-1825. Rio de Janeiro:

Tempo Brasileiro, 1967.

BURAWOY, M. O marxismo encontra Bourdieu. Campinas: Editora da Universidade de Campinas, 2010.

CARONE, Edgar. A Primeira República (1889 - 1930). São Paulo: DIFEL, 1969.

A República Nova (1930-1937). São Paulo: DIFEL, 1976.

A Terceira República (1937 - 1945). São Paulo: DIFEL, 1976.

CARVALHO, G. Luiz de. Imprensa Negra Paulista entre 1915 e 1937: características, mudanças e permanências. 2009. 210 f. Tese (Doutorado em História Econômica) FFLCH, Universidade de São Paulo. São Paulo, 2009.

COSTA, Emília Viotti da. Da Monarquia à República: Momentos Decisivos. São Paulo: Ed. Ciência Humanas, 1979.

CULLE R, J. Teoria literária - uma introdução. São Paulo: Beca Prod. Culturais Ltda., 1999.

DE ARAÚJO, Ricardo Benzaquen. Guerra e Paz, Casa Grande e Senzala e a obra de Gilberto Freyre nos anos 30. 2a Edição. São Paulo: Editora34, 2005.

Gilberto Freyre. Mal estar na Cultura, Porto Alegre, PROREXT-UFRGS, abr-nov 2010.

DEBORD, Guy. The Society of the Spectacle. NY: Zone Books, 1995.

A sociedade do espetáculo: comentários sobre a sociedade do espetáculo.

Rio de Janeiro: Contraponto, 1997

. O mito da democracia racial e a mestiçagem no Brasil. Diálogos

Latinoamericanos, $\mathrm{n}^{\mathrm{o}}$ 10, 2007.

. A nova abolição. São Paulo: Selo negro, 2008.

ELIAS, Norbert. O processo civilizador: Uma história dos costumes. Rio de Janeiro: Jorge Zahar Ed., 1994, v I.

O processo civilizador: Formação do Estado e Civilização. Rio de Janeiro: Jorge Zahar Ed., 1993, v. II. 
, DUNNING, Eric. A busca da excitação. Lisboa: Difel, 1991.

FERNANDES, Florestan. A integração do negro na sociedade de classes. 3. ed. São Paulo: Ática, 1978, v. 1.

FERREIRA, Maria Cláudia. Espaços de sociabilidade e ações anti-racismo no cotidiano das

elites negras na cidade de São Paulo: busca por projeção individual e legitimidade de grupo (1900-1940). Revista Mosaico, nº 3, ano II, 2010.

FREHSE, Fraya. Entre o passado e o presente, entre a casa e a rua: tempos e espaços na cidade de São Paulo de fins do império. Dissertação de mestrado, São Paulo, 2003.

FREYRE, Gilberto. Casa-grande \& senzala. 42. ed. Rio de Janeiro: Record, 2001. Novo mundo nos trópicos. São Paulo, Nacional/EDUSP, 1969. Sobrados e mucambos. Rio de Janeiro, Record, 1990.

GIDDENS, A. As consequências da modernidade. São Paulo: Ed. da UNESP, 1991.

GINZBURG, Carlo. Mitos, emblemas, sinais: Morfologia e História. $1^{\text {a }}$ reimpressão. São Paulo: Companhia das Letras, 1990.

O queijo e os vermes: o cotidiano e as idéias de um moleiro perseguido pela Inquisição. São Paulo: Companhia das Letras, 2005.

O inquisidor como antropólogo. In: O fio e os rastros. São Paulo:

Cia das Letras, 2007.

GRAMSCI, A. Cadernos do cárcere. Notas sobre o Estado e a política. (volume 3.) Rio de Janeiro, Civilização Brasileira: 2002

Concepção dialética da história. Rio de Janeiro: Civilização Brasileira. 1978a. 
Maquiavel, a política e o Estado moderno. Rio de Janeiro: Civilização Brasileira. 1978b.

Os intelectuais e a organização da cultura. Rio de Janeiro: Civilização Brasileira. 1978c.

GRENDI, E. "Microanálise e história social”. In: ALMEIDA, C. (org). Exercícios de microhistória. Rio de Janeiro: Editora da FGV, 2009.

GUIMARÃES, Antonio Sérgio Alfredo. A modernidade negra Teoria e Pesquisa, 42 e 43, jan./jul. São Carlos, Departamento de Ciências Sociais - CECH, Universidade Federal de São Carlos, 2003.

HOBSBAWM, Eric. Sobre a História. São Paulo: Companhia das Letras, 1998.

e Ranger, Terence. A invenção das tradições. RJ: Paz e Terra, 1990.

HOLANDA, Sérgio Buarque de. Monções. São Paulo: Brasiliense, 1985.

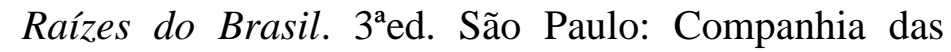

Letras, 1997.

JAMESON, F. Pós modernismo: a lógica cultural do capitalismo tardio. São Paulo: Editora Ática, 2001.

LE GOFF, Jacques. A história nova. São Paulo, Martins Fontes. 1990 [1978].

LÉVI-STRAUSS, C. "A estrutura dos mitos": In: Antropologia estrutural. São Paulo: Cosac\&Naify, 2005.

MALATIAN, Teresa. O tradicionalismo monarquista (1928-1945). Revista Brasileira de História das Religiões. ANPUH, Ano VI, n. 16, Maio 2013

Império e Missão - um Novo Monarquismo Brasileiro. São Paulo:

Companhia Editora Nacional, 2001. 
MARTINEZ, Monica. Jornada do Herói: A Estrutura Narrativa Mítica na Construção de Histórias de Vida em Jornalismo. Intercom, 2004. disponível em <http://www.intercom.org.br/papers/nacionais/2004/errata2003/jornada_heroi.pdf > Acesso em 20/12/2015.

MARX, Anthony. Making race and nation: a comparison of the United States, South Africa, and Brazil. Cambridge, Cambridge University Press, 1997.

MELLO, João Manuel Cardoso de. O Capitalismo Tardio. São Paulo: Brasiliense, 1982.

PEREIRA, Almícar Araújo. Mundo Negro: a constituição do movimento negro contemporâneo no Brasil (1970-1995). Tese de Doutorado). Universidade Federal Fluminense. Niterói, 2010.

PROST, Antoine. Doze Lições Sobre a História. Belo Horizonte: Autêntica. 2014.

SAID, Edward W. Cultura e Imperialismo. São Paulo: Companhia de Bolso. 2011.

SCHNEIDER, Alberto Luiz. Charles Boxer (contra Gilberto Freyre): raça e racismo no Império Português ou a erudição histórica contra o regime salazarista. Estudo História, vol. 26, n 52. Rio de Janeiro,julho-dezembro de 2013. p. 253-273

SCHUCMAN, Lia Vainer. Entre o "encardido", o "branco" e o "branquíssimo": raça, hierarquia e poder na construção da branquitude paulistana. 2012. Tese (Doutorado em Psicologia Social) - Instituto de Psicologia, Universidade de São Paulo, São Paulo, 2012.

SCHWARCZ, Lilia Moritz. Retrato em branco e negro: jornais, escravos e cidadãos em São Paulo no fim do século XIX. São Paulo: Companhia das Letras, 1987.

. O espetáculo das raças: cientistas, instituições e questão racial no Brasil 1870-1930. São Paulo: Companhia das Letras, 1993.

SILVA, Zélia Lopes. A memória dos carnavais afro-paulistanos na cidade de São Paulo nas décadas de 20 e 30 do século XX. Diálogos (Maringá. Online), v. 16, supl. Espec., p. 37-68, dez./2012

SOUZA, Ricardo Luiz de. História, poder e identidade nacional em Gilberto Freyre. MÉTIS: história \& cultura - v. 5, n. 10, p. 159-177, jul./dez. 2006 
SKIDMORE, Thomas E. Preto no branco: raça e nacionalidade no pensamento brasileiro. Rio de Janeiro, Paz e Terra. 1976 [1974]

SPITZER, Leo. Vidas de Entremeio: assimilação e marginalização na Áustria, no Brasil e na África Ocidental, 1780-11945. Tradução, Vera Ribeiro, Rio de Janeiro, EdUERJ. 2001.

\subsection{Livros e artigos especializados}

ABRAHAO, B. O. e SOARES, A. J. G.. A imprensa negra e o futebol em São Paulo no início do século XX. Rev. bras. educ. fís. esporte vol.26 no.1 São Paulo Jan./Mar. 2012. http://dx.doi.org/10.1590/S1807-55092012000100007

AGOSTINO, G., Vencer ou morrer. Futebol, geopolítica e identidade nacional. Rio de Janeiro, Faperj/Mauad, 2002.

ANTUNES, Fatima M. R. F.. O futebol nas fábricas - de diversão a trabalho. ComCiência. Campinas, n.79, 2006.

ARCHETTI, E. P.. "Estilo y virtudes masculinas en El Gráfico: la creacion del imaginário del futebol argentino", Revista de Ciencias Sociales del Instituto de Desarrollo Económico y Social. Buenos Aires, Argentina, 1995.

ARRUDA, Maria Arminda do N. Dilemas do Brasil Moderno: a questão racial na obra de Florestan Fernandes. In: MAIO, Marcos C. e SANTOS, Ricardo V. (Orgs.). Raça, Ciência e Sociedade. Rio de Janeiro: FIOCRUZ/CCBB, 1996.

AZEVEDO, Aldo Antonio. A imateriabilidade do trabalho do jogador de futebol: uma interpretação teórica. Sociedade e Cultura, v.11, n.2, Brasília, UnB, julho--dezembro, 2008. p.305-313

AZEVEDO, Fernando de. Da Educação Física: o que ela é, o que tem sido e o que deveria ser. Antinous: estudo de cultura atlética; A Evolução do Esporte no Brasil. $3^{\text {a }}$ ed. São Paulo. Melhoramentos, 19-?.

BARRETO, Lima (org.). A palavra é...futebol. São Paulo: Scipione, 1990.

BOURDIEU, Pierre. “O mercado de bens simbólicos” In: MICELI, S. (org.) A economia das trocas simbólicas. São Paulo. Perspectiva, 1974. 
. “Como é possível ser esportivo?" In: Questões de sociologia. Rio de Janeiro, Marco Zero, 1983-b.

. O poder simbólico. Rio de Janeiro, Bertrand: 1990 - a

. Coisas ditas. São Paulo: Brasiliense. 1990 - b

"A ilusão biográfica". In: Razões práticas: sobre a teoria da ação.

Campinas: Papirus, 1996.

O senso prático. Petrópolis: Editora Vozes, 2008.

. Sobre o Estado. São Paulo: Cia das Letras, 2014.

BROHM, Jean-Marie. Tesis sobre el deporte. In BROHM, Jean-Marie et al. Materiales de sociología del deporte. Madrid: Edicione de la Piqueta, 1993.

BROMBERGER, C. Le match du football: ethnologie d'une passion partisaine à Naples, Marseille et Turin. Paris, Éditions de la Maison de les Science de l'homme, 1995.

BROHM, J-M. Football, une peste emotionelle: La barbarie des stades. Edtions Gallimard, 2006.

BUARQUE DE HOLLANDA, Bernardo. Gilberto Freyre and the invention of footballart. Cadernos FGV Projetos, v. 8, p. 96-100, 2013.

. O cor-de-rosa: ascensão, hegemonia e queda do Jornal dos Sports entre 1930 e 1980. In: Hollanda, B. B. B. de; Melo, V. A. de.. (Org.). O esporte na imprensa e a imprensa esportiva no Brasil. Rio de Janeiro: 7Letras, 2012, v. 1, p. 80-106. .; MELO, Victor A (orgs.). O esporte na imprensa e a imprensa esportiva no Brasil. Rio de Janeiro: 7Letras, 2012.

; SANTOS, J.M.; TOLEDO, L..H.; MELO, V.A.. A torcida brasileira, Rio de Janeiro: 7 letras, 2012.

BUYTENDIJK, F.J.J. Psicologia do futebol. São Paulo: Herder, 1965.

CALDAS, W. O pontapé inicial. Memória do futebol brasileiro (1894-1933). São Paulo: Ibrasa, 1990. 
Aspectos sociopolíticos do futebol brasileiro. São Paulo, Revista da USP, n.22, p.40-9, 1994.

CAMPOS, Flavio de; VINCI DE MORAES, Z.G. (orgs.) Dossiê História e Futebol, Revista de História, São Paulo, USP, 163, 2ºm. 2010.

; ALFONSI, D. (orgs.) Futebol: objeto das ciências humanas. São

Paulo: Editora Leya, 2014.

CAPELATO, Maria Helena. O movimento de 1932: a causa paulista. São Paulo: Brasiliense, 1981.

CARONE, M. Cem anos de futebol. Memória, v.6, 20, 1994.

CARRANO, P.C.R. (org.) Futebol: Paixão e política. Rio de Janeiro: DP\&A, 2000.

CASTRO, Ruy. Estrela solitária: um brasileiro chamado Garrrincha. São Paulo, Cia. Das Letras, 1998.

CORBIN, A. e outros (dir.) História do corpo. Petrópolis: Vozes, 2010, 3v.

CARDIM, M. Guia de Football. 4aed. São Paulo: Casa Vanordem, 1906.

CORREA, M. Futebol, com a bola entre a cruz e a espada: uma pequena enciclopédia do futebol 1927 a 1972. São Paulo, 1973.

COSTA, M.R. et alli (orgs.) Futebol, espetáculo do século. São Paulo: Musa, 1999.

COELHO, Caco (org.). O Baú de Nelson Rodrigues. São Paulo: Companhia das Letras, 2004.

DA MATTA, Roberto. FUTEBOL: Ópio do Povo x Drama de Justiça Social. Novos Estudos Cebrap, São Paulo, v. 1, 4, p. 54-60, nov. 82.

O que fez o Brasil, Brasil?. Rio de Janeiro: Rocco, 1984.

Antropologia do óbvio. In: Dossiê Futebol. Revista USP. São

Paulo, n. 22, jun/jul/ago, 1993, p.17.

A bola corre mais que os homens. Rio de Janeiro: Rocco, 2006. 
DAMO, A. S. Futebol e identidade social: uma leitura antropológica das rivalidades entre torcedores e clubes. Porto Alegre: Editora da Universidade Federal do Rio Grande do Sul, 2002.

., "O ethos capitalista e o espírito das Copas do Mundo: as estratégias da FIFA para tornar as Copas lucrativas”. In: Nações em Campo: Copa do Mundo e identidade nacional, Simoni Lahud Guedes (org.). Niterói, Intertexto: 2006.

., Do dom à profissão: a formação de futebolistas profissionais no Brasil e na França. Porto Alegre: Rotschild \& Editores: 2007.

DA SILVA, Francisco Carlos Teixeira; DOS SANTOS, Ricardo Pinto. Memória social dos esportes. Futebol e política: a construção de uma identidade.

DE SOUZA, Denaldo Alchorne. O Brasil entra em campo, Construções e reconstruções da identidade nacional (1930-1947). São Paulo: Annablume, 2008. 220p.

DIETSCHY, P. Histoire du football. Paris: Librarie Academique Pérrin: 2010

DOMINGUES, Petrônio. Paladinos da Liberdade: a experiência do Clube Negro de Cultura Social em São Paulo (1932-1938). Revista de História 150 (1 - 2004), 57-79. Pag 76.

O Messias Negro? Arlindo Veiga dos Santos (1902-1978).

VARIA HISTORIA, Belo Horizonte, vol. 22, no 36: p.517-536, Jul/Dez 2006

DOS SANTOS, Jorge Artur. Os intelectuais e as críticas às práticas esportivas no Brasil (1890-1947). 2000. Tese (dissertação de mestrado). FFLCH, Universidade de São Paulo. São Paulo, 2000.

ELIAS, Norbert; DUNNING, E. A busca da excitação. Lisboa: Difel, 1992.

FIGUEIREDO, A. História do foot-ball em São Paulo. São Paulo, “O Estado de S.Paulo”, 1918.

FLORENZANO, J.P.. Afonsinho \& Edmundo: a Rebeldia no Futebol Brasileiro. São Paulo: MUSA. 1998. 
.A Democracia Corinthiana: práticas de liberdade no futebol brasileiro. São Paulo: FAPESP; EDUC. 2010.

FOER, F. How football expanis the world: un unlikely theory of globalization. New York, Arrow Books: 2004.

FONSECA, Marcus V. e DE BARROS, Soraya A. P. (orgs.) A História da Educação dos negros no Brasil. Niterói: EdUFF, 2016.

FRANCO JR., Hilário. Dança dos Deuses: futebol, sociedade, cultura. São Paulo: Companhia das Letras, 2007.

GALEANO, Eduardo. Futebol ao sol e a sombra. Porto Alegre: L\&PM, 1995.

GAMBETA, Wilson. A bola rolou: o velódromo paulista e os espetáculos de futebol. São Paulo: SESI-Editora, 2015.

GIULIANOTTI, Richard. Sociologia do futebol: dimensões históricas e socioculturais do esporte. São Paulo: Nova Alexandria, 2002.

; R \& ROBERTSON, R. Globalization \& Football. Londres: Sage, 2009.

GOLDBLATT, David. The Ball Is Round: A Global History of Soccer. New York, New York, U.S.A. Riverhead Books. 2008.

GORDON JÚNIOR, Cesar. - Eu já fui preto e sei o que é issoll: história social dos negros no futebol brasileiro: segundo tempo. Pesquisa de Campo, Rio de Janeiro, Eduerj, n. 3/4, p. 65-78, 1996. Futebol: síntese da vida brasileira.

- História social dos negros no futebol brasileiro: primeiro tempo: -essa maravilhosa obra de arte fruto da misturall. Pesquisa de Campo, Rio de Janeiro, Eduerj, n. 2, p. 71-90, 1995. Futebol e cultura brasileira.

GOUSSINSKY, Eugenio; ASSUMPÇÃO, João Carlos. Deuses da bola: história da seleção brasileira de futebol. São Paulo: Dórea Books and Art, 1998. 
GUEDES, Simoni Lahud. O Brasil no campo de futebol: estudos antropológicos sobre os significados do futebol brasileiro. Niterói: EDUFF, 1998.

HASENBALG, Carlos. Discriminação e Desigualdades Raciais no Brasil. Rio de Janeiro: Graal, 1979.

HELAL, Ronaldo. A construção de narrativas de idolatria no futebol brasileiro. ALCEU - v.4 - n.7 - p. 19 a 36 - jul./dez. 2003.

. A construção de um ídolo futebolístico na imprensa: estudo de caso.

ORGANICOM. ano $8 \cdot$ número $15 \bullet 2^{\circ}$ semestre de 2011.

HUIZINGA, Johan. Homo Ludens. São Paulo: Perspectiva, 1996.

MAZZONI, Tomás. História do Futebol no Brasil, 1894-1950. São Paulo: Leia, 1950. Almanach Esportivo. $1^{\circ}$ ano. São Paulo: Agencia Soave, 1928.

MELO, Victor A. de; PRIORE, M. del. História do esporte no Brasil. Do império aos dias atuais. São Paulo: Ed. Unesp, 2009.

MENDES, L. As táticas do futebol brasileiro: da pelada a Pelé. Rio de Janeiro: Tecnoprint, 1963.

MURAD, Maurício. Corpo, magia e alienação - O negro no futebol brasileiro: por uma interpretação sociológica do corpo como representação social”, Pesquisa de Campo/Revista do Núcleo de Sociologia do Futebol, Rio de Janeiro, Uerj, Departamento Cultural/SR-3, n. 0, p. 71-78. 1994.

Futebol e violência no Brasil, Pesquisa de Campo/Revista do Núcleo de Sociologia do Futebol, Rio de Janeiro, Uerj, Departamento Cultural/SR-3, n. 3/4, p. 89-103. 1996.

Dos pés à cabeça: elementos básicos de sociologia do futebol. Rio de Janeiro: Irradiação Cutlural, 1996.

MURRAY, B. Uma história do futebol. São Paulo: Hedra, 2000 
NEVES, J.; DOMINGOS, N. (orgs.). A época do futebol. O jogo visto pelas Ciências Sociais. Lisboa: Assírio Alvim, 2004.

NOGUEIRA, Cláudio. Futebol Brasil memória; De Oscar Cox a Leônidas da Silva (1897 - 1937). Rio de Janeiro: Ed. Senac Rio, 2006.

PARDINI, Melina Nobrega Miranda. A narrativa da ordem e a voz da multidão: o futebol na imprensa durante o Estado Novo (1937-1945). 2009. Dissertação (Mestrado em História Social) - Faculdade de Filosofia, Letras e Ciências Humanas, Universidade de São Paulo, São Paulo, 2010. Disponível em: <http://www.teses.usp.br/teses/disponiveis/8/8138/tde-04022010-130259/>. Acesso em: 2013-04-19.

PATUSKA, A. Os reis do futebol. São Paulo: Bentivegna, 1976.

PEREIRA, João Baptista Borges. Côr, profissão e mobilidade: o negro e o rádio de São Paulo. São Paulo: Editôra da Universidade de São Paulo, 1967.

RODRIGUES FILHO, Mário. O sapo de arubinha. São Paulo: Companhia das Letras, 1994. .O Negro no Futebol Brasileiro. $5^{\text {a }}$ edição. Rio de Janeiro: Mauad, 2010. Histórias do Flamengo. $4^{\mathrm{a}}$ edição. Rio de Janeiro: Mauad, 2014.

ROSENFELD, Anatol. Negro, macumba, futebol. São Paulo: Perspectiva, 1993.

RODRIGUES, Nelson. À Sombra das Chuteiras imortais. São Paulo: Companhia das Letras, 1994.

SALDANHA, João. História do futebol. Rio de Janeiro: Revan, $3^{\mathrm{a} e d ., ~} 1994$. . Os subterrâneos do futebol. Rio de Janeiro: José Olympio, 1963.

SANTOS, João Manuel Casquinha Malaia. Revolução Vascaína: a profissionalização do futebol e inserção sócio-econômica de negros e portugueses na cidade do Rio de Janeiro 
(1915-1934). 2010. Tese (Doutorado em História Econômica) - Faculdade de Filosofia, Letras e Ciências Humanas, Universidade de São Paulo, São Paulo, 2010.

SANTOS, Joel Rufino dos (Org.). História política do futebol brasileiro. São Paulo: Brasiliense, 1981.

SILVA, Diana Mendes Machado da. A Associação Atlética Anhanguera e o futebol de várzea na cidade de São Paulo (1928-1950) [doi:10.11606/D.8.2013.tde-29102013113153]. São Paulo : Faculdade de Filosofia, Letras e Ciências Humanas, Universidade de São Paulo, 2013. Dissertação de Mestrado em História Social. [acesso 2018-05-04].

SOARES, Antônio Jorge. Futebol, raça e nacionalidade no Brasil: releitura da história oficial. Rio de Janeiro, Universidade Gama Filho, Programa de Pós-Graduação em Educação Física, tese de doutorado, 1998.

. História e a invenção das tradições no futebol brasileiro. In:

HELAL, R.; SOARES, A.; LOVISOLO,H (orgs.) A invenção do país do futebol: mídia, raça e idolatria. Rio de Janeiro: Mauad, 2001a. p.13-50.

.; ABRAHÃO, B.. O futebol na construção da identidade nacional: uma análise sobre os jogos “pretos x brancos”. Rev. bras. Educ. Fís. Esporte, São Paulo, v.26, n.1, p.47-61, jan./mar. 2012.

SOUZA, J. Futebol-Arte. A cultura e o jeito brasileiro de jogar. São Paulo, Empresa das Artes, 1998.

SOUZA, Marcos Alves. Gênero e raça: a nação construída pelo futebol brasileiro. Cadernos Pagu, Campinas, n.6/7, p. 109-152, 1996. Raça e gênero.

TAYLOR, M. The association game: a history of british football. London, Pearson, 2009.

TOLEDO, Luiz Henrique de. Futebol e teoria social: aspectos da produção científica brasileira (1982-2002). In: Revista Brasileira de Informação Bibliográfica em Ciências Sociais. São Paulo, 2001.

. Lógicas no Futebol. São Paulo: Hucitec/Fapesp, 2002.

(org). Visão de jogo: antropologia das práticas esportivas. São

Paulo, Editora Terceiro Nome, 2008. 
TONINI, Marcel Diego. Além dos gramados: história oral de vida de negros no futebol brasileiro. Tese (Doutorado em História Social) Faculdade de Filosofia, Letras e Ciências Humanas, Universidade de São Paulo. São Paulo, 2010.

UNIVERSIDADE DE SÃO PAULO. Coordenadoria de comunicação social. Dossiê

futebol. São Paulo: Editora USP, 1994 (Revista USP).

WILSON, Jonathan. Inverting the pyramid: the history of football tatics. Londres: Orion Books, 2008.

WISNIK, José Miguel. Veneno remédio: o futebol e o Brasil. São Paulo, Companhia das Letras, 2008.

WITTER, J.S. O que é futebol. São Paulo: Brasiliense, 1990. 